\title{
(Re)Figuring Human Enslavement: Images of Power, Violence and Resistance
}

Ulrich Pallua, Adrian Knapp, Andreas Exenberger (Eds.)

Edition Weltordnung - Religion - Gewalt 5 



\section{SERIES}

\section{Edition Weltordnung - Religion - Gewalt}

Editor-in-Chief: Wolfgang Palaver

Editorial Board:

Andreas Exenberger, Wilhelm Guggenberger, Johann Holzner, Brigitte Mazohl, Dietmar Regensburger, Alan Scott, Roman Siebenrock, Kristina Stöckl, Claudia von Werlhof

Volume 5

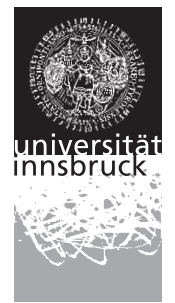


Supported by

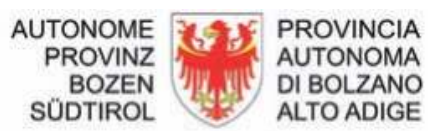

Deutsche Kultur

(C) innsbruck university press, 2009

Universität Innsbruck, Vice-Rectorate for Research $1^{\text {st }}$ edition.

All rights reserved.

Typesetting: Andreas Exenberger

Editorial office: Ulrich Pallua, Adrian Knapp

Coverdesign and Layout: Alexander Eberharter

Printed by Fred Steiner, Rinn

www.uibk.ac.at/iup

ISBN 978-3-902719-09-6 


\section{(Re)Figuring Human Enslavement: \\ Images of Power, Violence and Resistance}

Ulrich Pallua, Adrian Knapp and

Andreas Exenberger (Eds.)

Edition Weltordnung - Religion - Gewalt 5 

Table of Contents

9 Introduction: Re-Opening the 'Door of No Return' Ulrich Pallua, Adrian Knapp

\section{Challenging Literary and Visual Representations of Slavery}

21 Discursive Strategies in Fixing Images of Power: The Enslaved 'Other' in Miller's Art and Nature and Kotzebue's The Negro Slaves Ulrich Pallua

45 Silver Service Slavery: The Black Presence in the White Home Helen Mears

67 Re-Constructing Toussaint in the Romantic Era: History, Agency and the Haitian Revolution (1791-1804)

Franca Dellarosa

85 Resisting "Humanitarian Romanticism"? Thomas Pringle's "Pangola: An African Tale"

Adrian Knapp 


\section{De-Silencing Historical Testimonies}

109 Religion, Liberty, Violence, and Resistance in the Writings of Two Early Female Abolitionists

Judith Jennings

131 The Act of Remembering the 'Dis-Remembered': Sorting Out the Memorialisation of Liverpool and the Transatlantic Slave Trade Angela M. Leonard

149 All in the Family: Mixed-Race Jamaicans and their Imperial Networks in the Eighteenth Century

Daniel Livesay

\section{Detecting Post-Emancipatory Forms of Slavery}

169 Slavery is Sustained by the Purchase of its Productions: The Slave; His Wrongs and Their Remedy (1851-1856)

Sean Creighton

193 A One-Sided Controversy: James Hunt and Africanus Horton on The Negro's Place in Nature

Arno Sonderegger

223 A Shared Language: Creative Learning and Slavery Marcus Belben

247 List of Contributors 

Image 1: Porta di Lampedusa, Porta d'Europa

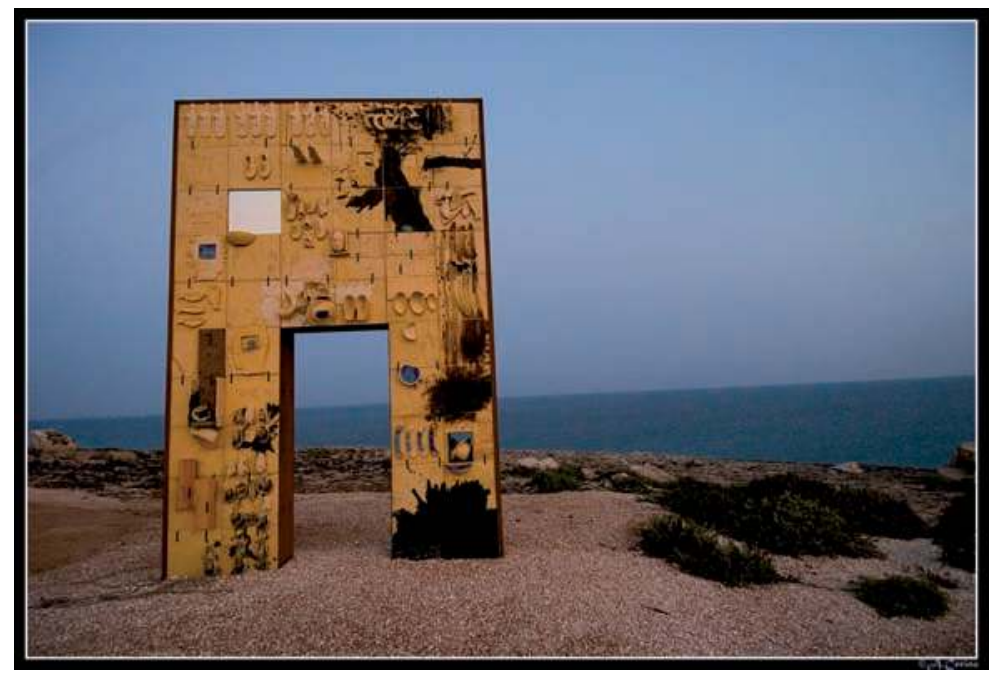

Source: Photo taken by Alessandro Cerino, Courtesy of Studio Mimmo Paladino. 


\section{Introduction: Re-Opening the 'Door of No Return'}

\section{Ulrich Pallua, Adrian Knapp}

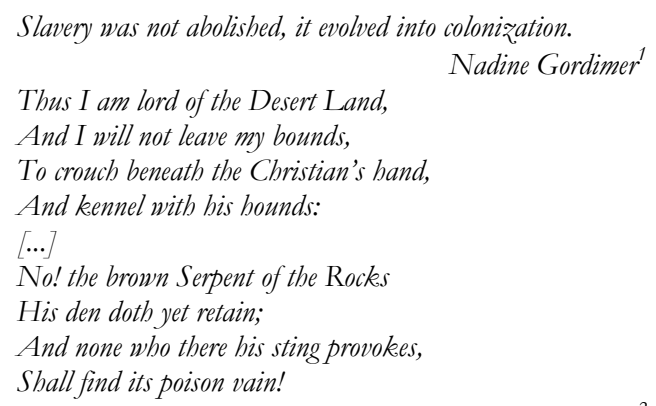

Thomas Pringle ${ }^{2}$

The unveiling of Mimmo Paladino's famous memorial in Lampedusa, Italy, on 28 June 2008 was widely celebrated as a historic event for Europe. 'Porta di Lampedusa, Porta d'Europa' or 'the Door of Lampedusa, the Door of Europe', as the Italian artist named his monument, is quite an impressive sight in itself. The five-meter-high and three-meter-wide door made of black refractory clay is a symbol for all the African migrants who tried to reach the Italian coast in the course of the last twenty years. While some of these attempts turned out successful, many resulted in unspoken human tragedies and a loss of life at sea. Paladino's memorial is also set to remind Europeans about the misery and suffering migrants had and still have to go through in their grief-stricken journey to Europe. ${ }^{3}$ Once past the 'Door of Europe' immigrants arrive in Italy hoping that their successful 'Passage to Paradise' will provide them with a vast array of possibilities denied to them in their home countries; needless to say, reality often turns out to be different blackening paradise's bright salvation with the dark colours of new forms of oppression and slavery.

1 Gordimer (2003), 27.

2 Pringle (1989), 12.

3 Of the 36,952 migrants reaching Italy in 2008, 30,657 first set foot in Lampedusa highlighting the dominant status of this island as an important stepping stone to 'paradise'. Porqueddu (2009). 
Considering the monument's gate-like shape in connection with African migrants' black skin colour commonly associated with "feelings of fear and insecurity"4 one is set to be reminded of the 'Door of No Return', a symbol for the abominable business of the transatlantic slave trade; Great Britain transported a yearly estimate of between seven and fifty thousand Africans to plantations in the Americas from 1770 to 1807 to boost European economic growth and territorial expansion. ${ }^{5}$ Before shipment to the Americas captured Africans were interned in camps on the African coast awaiting the arrival of slave ships to transport them to Europe's colonial 'Garden of Eden' which to them was closer to a 'Paradise Lost' fraught with European depravity. It was the boarding of the slave ship in Africa, symbolically referred to as passing the 'Door of No Return', that made African slaves realise that their future lay in an unknown place, far away from home and friends. Once removed from the slave ships in the European colonies, African slaves were left at the mercy of their new masters who in treating them like beasts of burden contributed greatly to fixing the image of Africans having inferior and debased qualities that need to be kept in check; it hardly needs mentioning that this burden of 'keeping in check' an 'inferior' people expressed itself in an unrestrained passion of violence and torture often resulting in the premature death of fellow human beings.

Despite the fact that these trans-atlantic voyages almost without exception describe a one-way movement from Africa to the Americas, one should not forget that doors themselves allow for a movement in both directions, denoting scenes of farewell and separation as much as those of homecoming and reunion. The re-cognition of these different directions largely forgotten when discussing issues of slavery shall function as the theme of this collection of essays working towards opening up and creating 'new' and additional space enabling us to see things differently and to get a more balanced picture of what slavery meant in the past and what it means in the present. As research has shown many times over, even after boarding the slave ships to the New World enslaved Africans never quite gave up hope and as such clearly remained agents of their own lives. In this respect the essays of this collection will try to do justice to the many

4 Fiumi (2008) translated by Pallua.

5 See The Transatlantic Slave Trade Database, Voyages. 
different experiences of former enslaved Africans acknowledging the influential power of the resisting 'brown serpent's poisonous sting' in changing colonial and metropolitan affairs outlined in Thomas Pringle's "Song of the Wild Bushman".

Questioning what we commonly understand to be slavery and the image of slaves evoked in our mind when thinking about past and present slavery seems to be a good start to create such 'new' space. More than 200 years after the abolition of the British slave trade 'slave' and 'African' are still perceived to be (at least semi-) synonymous terms causing bewilderment and scepticism at terms like 'white slaves' or 'European slaves'. ${ }^{6}$ What this conflation of the term 'African' and 'slavery' reveals, mixing one's place of origin with one's state of personal freedom, is that the trans-atlantic slave trade and slavery in the Americas is still regarded to be chiefly an African 'problem' of the past (and present) it is for Africans to solve and come to terms with. But as Walter Rodney rightly pointed out,

In East Africa and the Sudan, many Africans were taken by Arabs and were sold to Arab buyers. This is known (in European books) as the "Arab Slave Trade." Therefore, let it be clear that when Europeans shipped Africans to European buyers it was the "European Slave Trade" from Africa.

What Rodney's remark makes clear is that if there were more than one 'slave trade' then there surely was also more than one form of slavery and also more than one 'kind' of slave. This is exactly what constitutes the central theme of this collection of essays entitled (Re)Figuring Human Enslavement: Images of Power, Violence and Resistance challenging and resisting the monolithic and one-dimensional picture of slavery still prevalent in the West that seems too powerful and resilient to be abandoned and overcome.

This endeavour is all the more important as modern slavery is not all that different to its predecessor. According to the European Women's Lobby, about four million women and girls are sold into marriage, prostitution, and slavery every year and about 500,000 are

6 Don Jordan and Michael Walsh have only recently highlighted the great number of 'white' people (children of poor families, forced migrants such as vagrants and criminals, Irish peasants, kidnapped workers and the so-called 'free willers' or indentured servants) who were treated as slaves in the Americas before and after the beginning of the large-scale importation of African slaves. Jordan/Walsh (2008), 11-9.

7 Rodney (1982), 95 
trafficked into Western Europe alone. ${ }^{8}$ The fact that Italy's Numero Verde Antitratta ${ }^{9}$ received 494,000 messages of exploitation and violent attacks against foreign women between August 2000 and June 2006 is a telling example. ${ }^{10}$ At a closer look practices of slavery if not slavery as such seem to have regained ground in Europe where immigrants from Africa are "beaten with a baseball bat" for "stealing work from Italians" or are called "dirty black" while being beaten to death with a metal pole for allegedly "stealing a packet of biscuits." Jean-Léonard Touadi, Italy's first black MP of Congolese origin, has warned that "the spectre of fascism [is] returning to haunt Italy" as "Rome [has seen] taxi drivers chanting 'Duce, Duce' at the town hall when the new right-wing mayor was elected this year and now fans with swastikas are following the national football team." 11 Understanding slavery as a commonly accepted and never questioned form of "systematic violation of human rights"12 Italy like the rest of the West clearly has not come to terms with its past.

The dehumanisation of people on a large scale resulting in their systematic capture, enslavement and torture is made possible by belief systems that severely limit the possibilities of what our eyes are able to discern when meeting a stranger for the first time. Reconquering many of these abandoned possibilities is what this collection of essays sets out to do. Similar to Touadi who fears that "Italians are being led astray by their leaders" we have to question whether what we think we see is really what we see. This is true for the present as much as for the past; just as "second generation Italians from different origins and religions" have begun to "enrich Italian culture" 13 by protesting and speaking out on their own behalf, African slaves and sometimes even their masters fought against the colonial system built on slavery. Learning to see and interpret traces of resistance hidden in texts of the past will also enable us to see similar signs in the present and if not break down then at least cause

8 European Women's Lobby (2009).

9 The Numero Verde Antitratta is a helpline set up by the Dipartimento per le Pari Opportunità for the protection of victims of human trafficking.

10 Corriere della Sera (2008).

11 Kington (2008).

12 Kington (2008).

13 Kington (2008). 
a deep rift and fissure in the thick walls of a seemingly impregnable mind set.

This collection of essays is divided into three parts. The first part constitutes a reappraisal of literary and visual representations of slavery re-valorising hidden traces of resistance against domination and enslavement. In the first paper Ulrich Pallua concentrates on discursive macro-strategies confirming or subverting the positive/ negative dichotomy of images of African slaves and Europeans in two plays of the eighteenth century, James Miller's Art and Nature (1738) and August von Kotzebue's The Negro Slaves. The positive self- and negative other-presentation serves as a basis for eighteenthcentury stereotypical literary representations and depictions of the Other when mental models supporting the inferiority of foreign people became socially acceptable. Helen Mears in the second paper also focuses on how 'black' images and stereotypes became fixed in visual art confronting the legacy of William Hogarth with the works of two contemporary artists, Yinka Shonibare and Lubaina Himid, who in turning around the role of master and slave foreground the arbitrary assignation of knowledge and power in the discourse of slavery. In closely analysing the origin and dissemination of the image of the black domestic servant in the eighteenth century and juxtaposing it to Shonibare and Himid's work, Mears's postcolonial perspective re-discovers notions of black agency inherent in this colonial stereotype which she highlights by re-equipping Hogarth's black servants with such formerly disavowed character traits. Black agency also is central to Franca Dellarosa's paper which compares William Wordsworth's "To Toussaint L'Ouverture" and Edward Rushton's "Toussaint to His Troops" in how they differ in using Toussaint L'Ouverture's struggle against colonial tyranny to speak out against forms of oppression and enslavement. By foregrounding the two poets' personal interpretation of Toussaint's victories and defeats the paper shows how they created space for the enslaved to voice their personal resistance. The first section is rounded off with Adrian Knapp's discussion of the three different levels in Thomas Pringle's short story "Pangola: An African Tale" highlighting the benevolent coloniser's predicament in both siding with the revolting slave while at the same time calling for the suppression of the rebellion. Adapting Tayeb Salih's notion of the 'divided man' for his purpose and contextualising "Pangola" with Pringle's experiences narrated in his Narrative, Knapp is able to spot a benevolent coloniser's agency that 
albeit successfully bridging the experiences of the master and the slave is nevertheless tainted by a strong conviction that the colonial misery rests on the true benefits of European paternalism having so far been prevented from unfolding unhampered.

In contrast to the first set of papers the second section includes three essays offering interesting new perspectives on historical documents and testimonies. Judith Jennings's discussion of the lives and writings of two lesser known women poets, Mary Knowles and Anna Seward, links this section with the previous one. In addition to "integrating historical context and literary analysis" to "obtain a fuller picture of women's textual agency," Jennings also applies the argumentative parameters outlined in the Innsbruck project, English Literature and Slavery, 1772-183414 to discern the different "rhetorical and aesthetic strategies" used by Knowles and Seward in speaking out against the injustice of the slave trade. In the next paper Angela M. Leonard approaches slave captains' log books using Richard Jackson's concept of 'dis-memory' centrally concentrating on the "forgotten or rejected particulars of past experiences." In so doing, Leonard identifies five streams of trans-atlantic experiences making apparent the intrinsic collectivity that link the different agents in Liverpool with African slaves transported to the Americas and thus establishes a fuller picture of slave voyages than former analyses exclusively focussing on the trade's economic aspects have been able to. Daniel Livesay's paper discussing how interracial relationships in Jamaica fostered imperial networks that helped "the island's people of colour actively resist the structural and cultural impediments placed against them in the colony" also highlights the importance of these ties in offering a path to 'whiteness'. Livesay is able to show that through these "intimate familial bonds" the phenotype, in reflecting one's social standing, came to exert a great influence on British racial attitudes, not least since it also helped to mitigate the hardships of West Indian slavery in ways varying from financial support to manumission.

The final section deals with issues of slavery after 1838 when the apprenticeship system that was put in place to ease the transition from slavery to free labour was finally abolished. This period follow-

14 The six argumentative parameters outlined by Wolfgang Zach, Ulrich Pallua and Adrian Knapp are the racial/ethnic, religious, economic, legal/human rights, humanitarian, and national argument. 
ing the emancipation of West Indian slaves not only saw a shift of focus from the West Indies to the American mainland where slavery was to exist up until the Civil War of 1861-65 but also witnessed the first tentative stipulations of scientific racism. Arno Sonderegger traces this development of how race and racism became dominant issues in confronting people of different cultures in the 1860s comparing James Hunt's and Africanus Horton's diametrically opposed contentions about "the negro's place in nature." In so doing, Sonderegger reveals that by the mid-century, not least as a result of Darwin's findings, the anthropological establishment had become powerful enough simply to ignore Horton's well-based evidence rebutting their theory of the innate inferiority of Africans. Sean Creighton in his preliminary analysis of the monthly newspaper The Slave (185156) gives an overview of how the paper kept up the trans-atlantic fight against slavery by appealing to the conscience of consumers, as "Slavery is sustained by the purchase of its productions. If there were no consumers of slave-produce, there would be no slaves." Taking up Adam Smith's call from the previous century that slave produce was much dearer than free labour, Anna and Henry Richardson, the newspaper's editors, were not only successful in promoting the purchase of free labour produce but also ran fundraising campaigns to buy the liberty of prominent American slaves such as Frederick Douglass. The final paper of this collection takes the issue of slavery to the present illustrating different ways of creatively engaging people from different cultural backgrounds and age groups with past and present forms of slavery. Marcus Belben's overview of the project 'A Shared History, A Shared Future' conducted by Birmingham Library Services in 2007/08 to raise awareness about modern forms of slavery during the bicentennial celebrations of the abolition of the British slave trade rounds off this collection by juxtaposing lesser known forms of modern slavery with those commemorated in the years 2007/08. Belben's paper thus revisits aspects of slavery discussed in previous contributions and links them to the many different ways they manifest themselves in our time, ranging from the trafficking of people in the sex industry to the legal deportation of 'illegal immigrants' working in slave-like conditions, from the profit made from products restricting 'enemy combatants' in their mobility to the exploitation of child labour in the clothing and sports industry. Most importantly, the commemoration of Joseph Sturge's march from 1838 on 1 August 2007 has shown 
that there is an interest in understanding how people become slaves and what can be done against it, an interest in learning to see across one's self-imposed borders and creatively imagine what the world might look like when seen from the other side of the 'Door of No Return' and the 'Door of Europe'.

Similar to the ASHASF project undertaken in Birmingham in 2007/08 successfully re-directing its participants' gaze to present cruelties and injustices inflicted in our name, it is to hope that the unveiling of the 'Porta di Lampedusa, Porta d'Europa' has had and will have a comparable effect on the perception of immigrants in Europe. Although hardly comparable to highly distressing memories of pain, grieve and torment often associated with past and present forms of slavery it is still worth remembering that Italy has offered a possible way of confronting multicultural issues not only as a country of immigration. The northern province Trentino-Alto Adige (Trentino-South Tyrol) is home to three language groups - Italian, German and Ladin - living together in South Tyrol. This cultural diversity has not always been without problems and was the cause of a lot of friction in past decades. But as recent developments have shown, Italian representatives and groups who support a constructive collaboration with German-speaking groups have gained ground. This bodes well for the coexistence and cohabitation of different cultures in a region where a peaceful existence of Italian-, German- and Ladin-speaking groups has often been deemed impossible. This attempt at co-existing peacefully could serve as an example for how enriching reaching out to different cultures and breaking down old barriers can be in a country where the right-wing politician Umberto Bossi declared that he wouldn't refrain from prejudices regarding immigrants. ${ }^{15}$ It is to hope that the 'Door of Europe' will have a positive influence on how cultural difference is perceived and esteemed in South Tyrol on a small scale and Italy and Europe on a larger scale, as only seeing and honouring each other's different past and present circumstances will be able to bring people closer together rather than tear them further apart. 


\section{Works Cited}

Corriere della Sera (2008): "Tratta delle Immigrate, dal Sogno alla Strada," 8 June 2008, online at: http:/ / www.corriere.it (accessed on 25.3.2009).

European Women's Lobby (2009): “Facts and Figures about Gender Equality in Europe," online at: http://www.womenlobby.org/site/1abstract.asp? DocID $=404 \& v 1 \mathrm{ID}=\&$ RevID $=\&$ namePage $=$ \&pageParent $=\&$ DocID _sousmenu= (accessed on 27.4.2009)

Fiumi, Cesare (2008): "Emergenza o no? Razzismo," Corriere della Sera, 19 Nov. 2008, online at: http://www.corriere.it (accessed on 25.3.2009).

Gordimer, Nadine (2003): "New Introduction," in: Albert Memmi: The Colonizer and the Colonized. London: Earthscan, 27-44.

Jordan, Don/Walsh, Michael (2008): White Cargo: The Forgotten History of Britain's White Slaves in America. Edinburgh and London: Mainstream Publishing.

Kington, Tom (2008): "Black MP in Warning to 'Racist' Italy," The Observer, 19 Oct. 2008, online at: http://www.guardian.co.uk/world/2008/oct/ 19/italy-race-touadi-mafia (accessed on 3.4.2009).

Porqueddu, Mario (2009): "Immigrazione, chiede asilo il 75\% di chi arriva per mare," Corriere della Sera, 31 Jan. 2009, online at: http://www.corriere.it (accessed on 25.3.2009).

Pringle, Thomas (1989): "Song of the Wild Bushman," in: Pereira, Ernest/ Chapman, Michael, eds.: African Poems of Thomas Pringle, Pietermaritzburg: University of Natal Press, 11-12.

Rodney, Walter (1982): How Europe Underdeveloped Africa, revised ed. Washington, DC: Howard University Press.

The Transatlantic Slave Trade Database, Voyages: online at: http://www.slave voyages.org/tast/assessment/estimates.faces (accessed on 25.3.2009). 



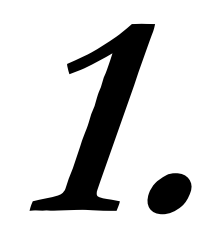

Challenging Literary and
Visual Representations of

Slavery 



\section{Discursive Strategies in Confirming Images of Power: The Enslaved 'Other' in Miller's Art and Nature and Kotzebue's The Negro Slaves}

Ulrich Pallua

\section{Introduction}

Collective symbols and images played a decisive part in $18^{\text {th }}$-century British colonisation as prejudices against, attitudes towards, and ideas about the 'Other' paved the way to ideologising other peoples' inferiority, thus justifying their colonisation and subjugation. Cultural and bodily 'anomalies' were instrumental for the British Empire in ideologically constructing 'an(Other)' identity, modelled as the counterpart to the European, dividing humankind into the benevolent British coloniser and the pitiful non-European slave to be rescued from his/her ignorance and educated. This evaluative process of a positive self-presentation and a negative other-presentation strengthened the consciousness of 'racial'/ethnic differences, in particular between Europeans and Africans. The ideological 'battle' about being part of the in- or out-group was above all fought amongst Europeans themselves: the greater the 'distance' kept between the supposedly superior and inferior peoples the more developed the civilisation of the former. ${ }^{1}$ Africans were considered a threat in terms of intercultural contact, and categorising them by conjuring up images of their inferiority made it easier to distance them from the civilised West. Biological and cultural differences - termed as "inegalitarian" and "differentialist/culturalist racism"2 - were the mainstay of racist

1 See Geulen (2007), 71.

2 Wodak/Reisigl (1999), 181. "[...] the concept of 'inegalitarian racism' is intended to denote the legitimisation of domination, discrimination, and separation based on overt 
discourse in the British Empire in its endeavour to demean Africans. This process of detaching Europe from barbarous Africa with its 'child-like' inhabitants required concocting fictitious traits and characteristics of Africans for the British public. Everyday racism, " $[\ldots]$ defined as socialized meanings making practices immediately definable and uncontested so that, in principle, these practices can be managed according to (sub)cultural norms and expectations"3 loomed large on the minds of the $18^{\text {th }}$-century readership, ${ }^{4}$ thus controlling, stigmatising, marginalising, and excluding the image of Africanness. Taking Ruth Wodak and Martin Reisigl's contention that "[...] racism, as a social construct, as a social practice, as an ideology, manifests itself discursively"5 as a starting point, this paper attempts to demonstrate that $18^{\text {th }}$-century stereotypical literary representations and depictions of the 'Other' affirmed the images of power colonial ideology had produced of non-Europeans. At the same time, subjecting the discursive strategies - attitudes, convictions, and stereotypes - adopted by writers in portraying the out-group in their works to scrutiny will uncover how writers cognitive-linguistically succeeded in internalizing prejudices/stereotypes by "[...] delineate[ing] the out-group," 6 or, quite contrarily, how they turned the table on racist argumentation by portraying the 'savage' as a simple but noble creature impersonating the "voice of nature and reason," using these stereotypical representations to sully the sense of belonging to the in-group made to exploit and enslave the out-group.

\section{Discursive Strategies}

An analysis of the discursive strategies adopted by writers aims at scrutinising the relationship between images and ideological tenets in the language used to describe and position non-European characters

doctrines in support of genetic, biological inferiority, whereas 'differentialist racism' emphasises cultural differences, including lifestyles, habits, customs and manners, and paints a threatening picture of the mixing and interbreeding of cultures and ethnic groups." Reisigl/Wodak (2001), 9.

3 Essed (1991), 50.

4 Even if Geulen rules out the possibility of racist thinking in terms of control and suppression of 'inferior races' in the $18^{\text {th }}$ century; see Geulen (2007), 58.

5 Wodak/Reisigl (1999), 175.

6 Wodak/Reisigl (1999), 182.

7 Miller (1738), 54. 
in their works. As literature is addressed to a particular readership, the analysis will have to deal with social identities, cultural values and stereotypes used to collectively juxtapose two different cultures. "Discourses wield power by transporting knowledge that supplies collective and individual consciousness. This knowledge is the basis for individual and collective action and the shaping of reality." analysis of discursive strategies should therefore place special emphasis on the discourse practices and discourse positions of the respective writers within the different discourse levels. A critical discourse analysis of the plays will reveal the "biased discourses, and the ways these polarize the representation of us (in-group) and them (out-group);"' it is the "mental models"10 developed from ideological attitudes and beliefs that need to undergo scrutiny in order to reveal how images of inferiority and oppression became socially acceptable and shared opinions: "Recipients tend to accept beliefs, knowledge, and opinions through discourse from what they see as authoritative, trustworthy, or credible sources [...]."11 The colonial discourse laid the foundations for images of power in the contact zone, that is, they placed emphasis on the fixity of the image of the 'Other' as inferior and subservient.

Discursive strategies transport prejudices and stereotypes used to group different people according to preconceived categories simplifying socially acceptable norms. As Wodak and Reisigl point out,

On the one hand, racist opinions and beliefs are produced and reproduced by means of discourse; discriminatory exclusionary practices are prepared, promulgated, and legitimated through discourse. On the other hand, discourse serves to criticise, delegitimate, and argue against racist opinions and practices, that is, to pursue antiracist strategies [and can therefore also] have an effect on the dismantling or even destruction of the status quo. ${ }^{12}$

The discursive strategies of writers are an essential feature of the discourse to be analysed as they reveal how the respective out-group is referred to linguistically, which "traits, characteristics, qualities, and features" they are attributed to, and which arguments are used "to

\footnotetext{
8 Jäger (2001), 87. (my translation)

9 Van Dijk (2001a), 103.

10 Van Dijk (2001a), 112.

11 Van Dijk (2001b), 357.

12 Wodak/Reisigl (2001), 372, 385.
} 
justify and legitimate the exclusion, discrimination, suppression, and exploitation of others."13 According to Michael Hays, "the socioaesthetic specialisation of imperialist discourse must prevail in a multiplicity of cultural realms, and in all social groups at home before it can be fully implemented as a universalizing discourse abroad." 14 A qualitative analysis of the discursive strategies applied to depict the 'Other' gives insight into the ideology of the time: "Discourse analysis has to be conceived as analysis of society that aims at disentangling the net of the entire discourse of a society by bringing out the single discourse strands at the single discourse levels" 15 Discourse analysis therefore concentrates on the self- and other presentation of the confronting cultures, especially on the categorisation of the members of the two groups "by referring to them by virtue of ascribing to them identities, functions and positive or negative evaluations they share with others."16 The marginalisation of the out-group then leads to what Reisigl calls "monoculturalization/monolingualization" 17 where the antagonistic culture is passivised, oppressed, and its voices silenced. The ethnocentrism or "Whitecentrism/denigration of culture" 18 evaluatively dismissed all non-Europeans as inferior, thus cultureless and in need of being civilised/educated.

A crucial element of the "social practices oppression, suppression, exclusion, or marginalization of out-group members by ingroup members"19 is the prejudiced group attitude towards the respective 'inferior" culture as it is shared by all "members of a social group [with] generalizations based on lacking, insufficient, or biased models [maintaining] in-group dominance, power, and exploitation, or the protection of interests or privileges. In this respect, ethnic prejudice is the cognitive foundation of racism." 20 According to Blumer, "The basic tenets of prejudice are (a) a feeling of superiority, (b) perception of the subordinate race as intrinsically different and alien, (c) a feeling of propriety claim to certain areas of privilege and advantage, and (d) fear and suspicion that the subordinate race wants

\footnotetext{
13 Reisigl/Wodak (2001), 385.

14 Hays (1995), 71.

15 Reisigl/Wodak (2001), 27.

16 Reisigl/Wodak (2001), 47.

17 Reisigl (2000), 210.

18 Essed (1991), 10.

19 Van Dijk (1993), 24.

20 Van Dijk (1987), 195
} 
the prerogatives of the dominant race."21 The Discourse-Historical Approach relies on

at least four types of discursive macro-strategies: constructive strategies (aiming at the construction of national identities), preservative strategies (aiming at the conservation and reproduction of national identities or narratives of identity), transformative strategies (aiming at the change of national identities), and destructive strategies (aiming at the dismantling of national identities). ${ }^{22}$

The following analysis of two $18^{\text {th }}$-century plays, James Miller's Art and Nature (1738) and August von Kotzebue's The Negro Slaves (1796), will concentrate on the authors' strategies in either confirming and/or deconstructing prejudices and stereotypical images of the African slave and the "Wild-man [...] from the American Forests." 23

\section{James Miller: Art and Nature (1738)}

For a critical analysis of the plays it is of vital importance to sketch out the various discursive strategies used by the authors to argue for or against the slave trade and slavery as such in order to differentiate between the diverse argumentative strands. In Art and Nature James Miller's arguments can be divided into the following contrasting opposites: (1) the wild and ingenuous slave vs. the European governed by laws but become corrupt, (2) the degeneracy of Europe and the 'western' world vs. the noble brute representing untouched nature and the 'antidote' to corruption, but still considered a simpleton, and (3) Europe as the redeemer saving slaves from their ignorance vs. subservient slaves expected to be thankful for being enlightened.

Set in England the play revolves around Truemore, who returns from the West Indies with Julio, a native of the American woods. Sir Simon Dupe, Flaminia's father, has promised his daughter to Truemore, but believing rumours that Truemore has lost all his possessions breaks his vow and promises Flaminia to Truemore's friend Outside instead. Julio, personifying "the Voice of Nature and Rea- 
son," 24 challenges the images of power of the British colonial ideology by exposing Europe's degenerate society. Let us now take a look at how the aforementioned contrasting opposites are represented in Miller's play.

(1) When "Julio, a Savage" 25 first appears, he questions the contradicting attractiveness of Europe while Truemore conjures up the image of the "Wild-man," the "poor Wretch" with "pure natural Wit, strong good Sense and Integrity of Soul," whose "pure simple Nature" is seen as the opposite pole to "Laws, Arts and Sciences." 26 Julio, resembling the out-group, is referred to linguistically as an inferior creature representing nature untouched by corruption. Even if Miller lets Outside claim that the western world is a "vile Corner of the World [permeated by] Fraud and Dissimulation; nothing is to be met with but base Flattery, Treachery and Injustice," 27 it is Violetta, Flaminia's maid, who feels an obligation to remind Julio, the "stupid Head," of his ignorance to recognize the "Rules and Orders [which] make Men wise and honest" and the "Beauty of Order and Politeness in others [which] makes us humain and good-natur'd." 28 Julio replies to Truemore by accusing Europeans of behaving like

Fools, who call your selves Wise; Ignorant, who imagine your selves Learned; Poor, who fancy your selves Rich; and Slaves, who believe your selves Free $[\ldots]$ you eagerly pursue useless Trifles; you are Poor, because you place your sole Happiness in Money, instead of enjoying full Nature as we do, who in order to possess ev'rything without Restraint, monopolize nothing; you are Slaves to your Possessions, which you prefer to your Liberty, and your Brethren whom you'll hang for taking a trifle of that which is of no use to your selves; and you are Ignorant, because all your Wisdom consists in the knowledge of the Laws, whilst you neglect pure Reason which wou'd prevent your having any occasion for 'em. ${ }^{29}$

When Truemore asks Julio how to live without money, Julio counters that in "the native Woods I had known neither Riches nor Pov-

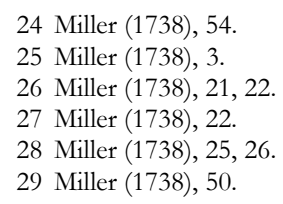


erty. I had done every Office for my self, been at once Master and Servant, King, and Subject; from this State of Happiness and Freedom you have drawn me, to teach me, that I am only a miserable Slave, faithless, base, inhuman Wretch." ${ }^{30}$ In this self- and other presentation the roles are reversed when the slave challenges the morality and validity of Western existence, which is then quickly dismissed again by Truemore offering Julio to assist him with money, at the same time disavowing the truth and turning a deaf ear to Julio's wish to return to his woods:

But I'll not take any thing of you, since you give nothing for nothing; and I can give you no Money. What! you'd have me give you my self, would you, to be a Slave for a little of your glittering Trash? No; I'll have my Liberty if I have nothing else; I'll be free tho' I am poor; carry me back then to the Place from whence I came; give me my Woods and Wilds again, that I may in them forget that there are Rich and Poor in the World. ${ }^{31}$

The act of contrasting native life in the American woods and civilised life in Europe reaches its peak when Flaminia asks Julio whether to marry Truemore against her father's will, labelling Julio as "the Voice of Nature and Reason," 32 to which Julio responds, "The People of this Country are so given to lying themselves, they think no body else can speak Truth" calling them "Fools" and "a Couple of Asses." ${ }^{33}$ The collective identities, negative out-group vs. positive in-group, are interchanged linguistically referring to the supposedly superior Europeans as "Fools" and "Asses;" it is the Europeans" "Interest to be base, false and dishonourable" conjuring up the image of the white man as "shameless Animals...I shall certainly be devour'd by some of 'em at last." 34 The confrontation of "Prejudice of Education" and "Prejudice of Nature and Reason" 35 induces Outside to realise that he has been blinded by his greed for money: "What shocking Truths has that Creature utter'd! How divine a Bliss is conscious Innocence!" But soon after he disregards the uttered truth as he "mustn't be preach'd out of [his] Purposes by a Natu- 
ral." 36 The fact that Julio is identified as an innocent creature ignorant of the benefits of European society leads Outside and Truemore to disregard Julio's offer to go back to the woods with him - a possible reversal of the coloniser dragging the underdeveloped 'race' from their base surroundings to a civilised environment, in this particular case the colonised taking the coloniser back to the world of untouched human nature,

Come along with me then, I'll take you to a Country where we shall have no need of Money to make us happy, nor Laws to make us wise; our Friendship shall be all our Riches, and Reason our only Guide [...] Let us hear no more then of your Laws, your Arts, or your Sciences, for they are good for nothing, by what I have seen yet, but to give Knaves an Advantage over honest Men, and Fools Authority over wise ones - No, no, let us go, and enjoy our selves, and be as happy as Nature and CommonSense can make us. ${ }^{37}$

The prejudice of the wild 'savage' who is prone to use violence to accomplish his goals, combined with his uncivilised state resulting in not knowing how to behave and in the coloniser's duty to answer for his deeds, is confirmed with a preservative strategy, asserting that "if you dare put me in a Passion, I'll thrash you, and all the Rogues that belong to you." 38

(2) The degeneracy of Europe is closely interrelated with the collision of the two 'worlds', and it is Julio who initially contradicts Violetta when she attributes his ignorance to the fact that he has lived among 'savages' in the woods rather than in the "civiliz'd part of the World;" Julio, on the contrary, labels Europe as the place where the real 'savages' live calling it a "mighty villainous Country indeed" with "big-looking Savages, that domineer over their FellowCreatures, most of whom seem to be better than themselves." ${ }^{39}$ The reader detects a note of irony when Julio avers that "by meer observing how you act, no body cou'd dream you were such excellent Creatures." 40 By juxtaposing "savages" with the "civiliz'd part of the World," and "Savages" with "excellent Creatures" the author plays 
with cultural values in that the two images are stereotyped, aiming at the construction of two national identities freely interchangeable. Julio takes the terminology of western discourse and creates this image of corrupt and hypocritical Europe. When Julio meets with Sir Simon Dupe who confronts him with his backwardness by calling him "Animal," "Monster," "Brute," "Poor Creature," and "miserable Wretch," 41 he brings this 'counter-evaluation' to perfection by stressing the positive spatialisation of the woods against the negative spatialisation of Europe's cultural values, including the striving for fame and possessions: "we are all naturally wise and honest enough; we have no need of being forc'd to do our Duty; we are so very ignorant, that meer natural Reason is enough for us...I sleep well, eat well, drink well, I fear nothing, care for nothing, nor wish for nothing; now if this is Misery, what is your Happiness, Mr. Great Man?"42 Julio's question "Is this then the only Happiness of the Great, to have more Dishes to gaze upon, more Hours to do nothing in, and more Sicknesses and Doctors to be tormented with"43 confirms the vanity of European arrogance and clinging to "Wealth, Lands and Possessions in abundance." 44 It is their ignorance ${ }^{45}$ and hollowness that makes Europeans assume their innate superiority: "these People an't what they seem to be; and every thing they have is borrow'd; their Good-nature, their Understanding, their Wit, their very Hair." 46 Julio is portrayed as the lovable "Brute" and "Monster" 47 whose "moral' attractiveness is acknowledged but who is still considered a "simpleton" 48 not able to comprehend the 'doings' of civilised Europe - "I shall never find out the Meaning of these Country Savages; there's strange Doings, strange dark kind of Doings amongst 'em" 49 - and her innovations and achievements. He is the 'noble brute' embodying untouched nature and the antidote to

41 Miller (1738), 32, 33.

42 Miller (1738), 33.

43 Miller (1738), 34

44 Miller (1738), 33.

45 Julio intentionally makes fun of their inability to discern the right moral values by contrasting it to him being so ignorant as to simply rely on reason.

46 Miller (1738), 39.

47 Miller (1738), 27.

48 Miller (1738), 27.

49 Miller (1738), 35. The ambivalence of this statement is quite telling as it also hints at the fact that Julio, as the child of nature and reason, does not understand Europe's corruption. 
corruption. When he asks Violetta if the people in Europe "are skilful in making these Glasses that shew you your own Faces, why don't you make some that shew the Mind and the Thoughts as well?", she realises that nobody would really care for such an invention, "they'd very seldom bear the Seeing, I'm afraid," 50 covertly pouring scorn on her own people's morality. Julio's master Truemore, however, only criticises the gap between rich and poor; he generalises the issue of in- and out-group relations by drawing the attention to inner-European problems of class and rank.

The Happiness which you imagine in their Condition, is very often the Cause of their Misery...Because Riches only multiply Mens Cares; the Poor labour only for the Necessaries, but the Rich for the Superfluities of Life; which are boundless by reason of their Ambition, Luxury, and Vanity which consume them; thus the rich Man's Wealth is the Cause of his Labour and Want. ${ }^{51}$

(3) The image of the violent slave to be subjugated is intertwined with him/her being thankful for being introduced to civilised 'existence', "You ought at least to thank me for saving you from the Gallows." 52 Julio's question why Truemore has taken him "hither, into a civiliz'd Country, as you call it; where the Virtue you pretend to, is only a Snare for the Credulity of those you want to deceive. I find that there is neither Truth, Honour nor Honesty in any of you," is dismissed as irrelevant, instead drawing the attention to the issue of money, an essential quality in the characterisation of the 'corrupt' in-group: "we don't here live in common as you do in your Woods; ev'ry one has a Property of his own, and no body must take what does not belong to him, without giving Money for it." ${ }^{33}$ James Miller creates collective symbols of Europeans and non-Europeans by categorising them according to the then predominant ideology. Even if at first glance he attempts to suggest that the European lifestyle and its cultural background are corrupt and degenerate compared to the purity and reason of Julio, it is evident that the 'corrupt' characters do not really give credence to what Julio has to say. Thus, Miller 
not really aims at dismantling the national identity of Europeans by adopting a destructive strategy but instead pursues a preservative strategy confirming Europe's identity, even if it is a 'corrupt' one. The first "apparent concession" is turned into "apparent denial and negation," corroborating the "ignorance" of the characters and their obvious self-appropriation and resulting stereotyping of others: Julio is portrayed as the passionate and unruly slave sketched in the "hyper-positive image [where] Africans are depicted as being superior to Europeans in their morals thus functioning as foils to European Vice," 54 embodied by the paternal white master disdaining Julio's higher moral tenets. Julio as the rational human being is given the permission to articulate his abhorrence of Europe's corrupt nature but is then 'silenced into the background' and subjected to Europe's powerful image of capitalist profit personified by the benevolent and paternal characters Truemore, Outside, Sir Simon Dupe, and Flaminia.

\section{August von Kotzebue: The Negro Slaves (1796)}

Kotzebue's play stages the 'battle' of argumentative strategies of abolitionists and supporters of the slave trade; set in Jamaica the story centres around the brothers John and William, who inherited a plantation from their father, a benevolent master. The aforementioned 'battle' takes place between John and William, the former representing West Indian avarice and the brutality of the slave system, the latter personifying the benevolent planter attempting to improve the slaves' conditions. The two slaves Zameo and Ada, husband and wife, are reunited after having been separated in Africa; together with the other slaves Truro, Ayos, and Lilli, their experiences on the plantation serve to illustrate the clash of two apparently opposing ideological tenets: economic profit vs. humanity. The play is truly outstanding, it is both a pamphlet written on behalf of enslaved Africans and a manifesto for Britons and other European countries, denouncing the inhumane treatment of slaves in the colonies. The different arguments used by John and William display the discursive strategies of abolitionist discourse: (1) the inhumane treatment of

54 Knapp/Pallua (2008), 13. For the six meta-images of Africanness see: Knapp, Adrian/Pallua, Ulrich (2008): "Images of Africa(ns): Racism and Ethnocentricity in the British Abolition Debate: 1787-1834,” in: Innsbrucker Diskussionspapiere zu Weltordnung, Religion und Gewalt 26, 12-13. 
slaves in the West Indies and the indifference of planters towards them, (2) prejudices about Africans, and (3) Europe's duty to educate poor ignorant slaves.

Kotzebue successfully dissociates himself from the cruel trade in slaves and dedicates his work to William Wilberforce who is seen as "an attentive observer of your active zeal for the abolishment of slavery [...] The sufferings of the unfortunate class of Slaves cannot fail to excite commiseration and enthusiasm in every tender heart," 55 and to the Danish Counsellor of Justice and King of Denmark's agent "because the Danes were the first who dissolved the fetters of this unfortunate race $[\ldots]$. ."56 Kotzebue's destructive strategy aims at dismantling the stereotypical representations of Africans, rebutting the prejudice of Africans as being different from Europeans with respect to "their intellectual capacities." 57

(1) The cruel treatment of slaves is brought to the attention of the reader in two ways: the slaves themselves disclose the inhumane conditions under which they have to dwell, "we, scorched with the burning sun, and waked with stripes of the whip, bedew the hard ground with sweat and blood" calling "None of the Whites good for any thing." 58 Truro recounts how Africans are enslaved once captured in Africa, taken aboard a ship, and transported to the colonies:

Mind and body are both subdued by affliction and chains; their heads are fixed between great wooden forks, supported behind with iron cramps; not one can stir a step without the other; all walk in procession panting under the heavy fork. Their fettered hands are not at liberty to wipe off the sweat. It is with tears alone that they can wash the blood and sweat from their faces. In this manner you conduct your slaves to market. Your cattle at least go free to the slaughter-house. ${ }^{59}$

\footnotetext{
55 von Kotzebue (1796), 1-2.

56 von Kotzebue (1796), 2.

57 von Kotzebue (1796), 3.

58 von Kotzebue (1796), 9, 11. Truro, the "old free negro" (4) puts it in a nutshell when he divulges how Africans are enslaved and oppressed: "In this way we are treated, because we are black" (33) to which Lilli and Ada reply: "Lilli: And yet the mother's milk which we sucked was white. Ada: And our blood too is warm and red." (34) It is their different skin colour that bars them from liberty, freedom, and dignity, "A Negro has no rights. Every European, even a stranger may lash him with impunity, and if the Negro lifts up his hand against him, it is death.” (34)

59 von Kotzebue (1796), 48
} 
On the other hand, the planter John outlines the need to torment slaves in order to make them obedient, "Believe me, hunger is even more persuasive than Fox, and a single crack of the whip operates more powerfully than all the eloquence of a Burke...I had her whole body pricked with needles; then cotton dipped in oil was twisted round her fingers, and lighted. Three days after she loved me most tenderly." 60 Another slave was "flayed, and salt and Spanish pepper to be strewed on it." 61 The reckless disregard for their life goes so far as to work them to death, "He will be too old, soon, we must let him die quietly by degrees. Let him work less, and give him less to eat, till at last he goes out like a candle." ${ }^{2}$ His benevolent brother William stands in marked contrast to John: "Brother, if you will but let the devil know that you have set up a school here, I will bet a wager he comes to take a lesson of you." ${ }^{63}$ The demonisation of the planter implies a reversal of cultural values and identities in the self- and other presentation as it is the greed of the white man ultimately triggering off his countrymen's economic urge to trade in slaves. Truro observes, "My countrymen fought very few battles formerly, and whenever they did, it was for a dozen of fish, or a handful of salt; but now they massacre each other daily that they may sell those who are left... We traded formerly in dried fish, linen, wax and ivory. But from you we have learnt to trade in men." 64 Kotzebue calls it "necessity" 65 when Africans are compelled to sell their own children into slavery, when "400 of my brethren lay in piles upon each other," the "weary, the sick, the sleeping, and the dead," producing an atmosphere of "silent melancholy" proceeding to "deep affliction," "surpassing despair" and finally to "death." 66 Zameo sums it up by claiming that "The European serves us as we do the palm-tree; we extract the juice, and let the dead stick remain." 67 This metaphor captures the essence of Kotzebue's play when John asserts that he

60 von Kotzebue (1796), 11, 13.

61 von Kotzebue (1796), 18. "The heat of the fire before which he is constantly sweating, has so parched him, that at every stroke, the skin rose from the bones as the shell does from the coffee." (18)

62 von Kotzebue (1796), 18.

63 von Kotzebue (1796), 18.

64 von Kotzebue (1796), 48.

65 von Kotzebue (1796), 49.

66 von Kotzebue (1796), 53-54.

67 von Kotzebue (1796), 55. 
controls both mind and body but only wants to exploit the body. Not interested in Ada's 'mind,' her feelings, it is the body he strives to have control over, no matter if she is still in love with her husband Zameo, "you possess another jewel, personal charms, visible to my eyes, sensible to my feelings; a jewel which you may dispose of without your heart. This may remain Zameo's property; but I bought the other with money, and yet my generosity makes me a petitioner to you for it." ${ }^{6} 8$

A quality of the in-group that Kotzebue also presents to the reader is the indifference of the West Indian planters being used to the brutality of the system they are part of. To William's question, "do you know you are carrying on a vile trade? When the Overseer flogs out the poor slaves at sun-rise, do their cries never wake you?" John answers, "I am used to it." ${ }^{69}$ William, on the other hand, appeals to the reader's empathy, "is it in the nature of man to reconcile himself to every thing, and even to wean himself from common humanity?" 70 in his attempt to positively 'upgrade' the out-group. At the same time William avows that all European nations somehow debase Africans by superimposing their own vices onto them, the Englishman being certainly worst:

The Spaniard makes the negroes companions of his indolence, the Portuguese makes them subservient to his vices, and the Dutchman abuses them as the victims of his avarice. The Frenchman makes them bend to laborious work, and often refuses them necessaries; but he sometimes laughs with them, which lightens their misery. The Englishman never laughs, never shews them any condescension. ${ }^{71}$

(2) Kotzebue addresses the presentation of the out-group by dealing with common prejudices about Africans. John and his overseer Paul confirm the existing images of power: their superstitious beliefs: "The fools always think that we are only fattening them in order to eat them... One of them asked me very seriously whether my shoes were made of negro-leather, because they were black!"; their unwillingness to work: "Laziness will not do here, as in your 
hot sandy deserts;"72 and their being easily pleased: "So little is sufficient to animate the Negro, give him but a bagpipe and a glass of genuine rum, and he will work for weeks together without murmuring." ${ }^{73}$ This preservative strategy employed by John stating that slaves are "cunning, vicious and stupid" 74 and that "They acknowledge the superiority of our minds, and of course the justice of our dominion," 75 is refuted by William's transformative strategy determining who is to be held responsible for the present misery:

They are stupid because slavery destroys all energy of mind; they are ill-disposed, but they do not shew it to you, as you deserve. They lie, because no one dares to speak the truth to tyrants. They acknowledge the superiority of our minds because we keep them in eternal ignorance; and the justice of our dominion, because we abuse their weakness. - Alas! you have done every thing in the world to depreciate these un-unhappy wretches, and then you complain that they are stupid and evil-inclined. ${ }^{76}$

This direct confrontation of William and John's standpoints is a savvy tactic to display the vast array of strategies adopted in the abolitionist debate on both sides: when John asks William whether Africans are not "born to be slaves," William counters that "No man can be born a slave... The liberty of man is invaluable!...He belongs to his first master, to God, who never gave him his liberty! a man may sell his life as a soldier, but not the abuse of his life as a slave." ${ }^{\prime \prime}$ The question whether slaves should be treated as human beings or whether "they are a race, destined by nature to slavery" because "They descend from Cain, they are black, because the father of their family was the first who killed his brother," is not properly answered by William who only throws the following question at John: "Where has God stamped the mark of slavery on them?" 78 It is not just the planter/coloniser John who is convinced of the naturalness and 're-

\footnotetext{
72 von Kotzebue (1796), 19.

73 von Kotzebue (1796), 39

74 von Kotzebue (1796), 24. "They are all lie and deceit, they are ungrateful and perfidious, they would with all their hearts poison every one of us." (58)

75 von Kotzebue (1796), 24.

76 von Kotzebue (1796), 25.

77 von Kotzebue (1796), 25.

78 von Kotzebue (1796), 24.
} 
ligious legality' of the slaves' innate bondage, but also the slaves themselves who seem to have lost their faith in God:

God has created Blacks only to suffer. I was stolen from my parents, when an infant, and sold for a copper kettle. My days dragged on between work and hunger, and my nights were passed in feverish sleep and tears, till they gave me a husband that I might bring more slaves into the world...would to God, my good master, my mother had been as compassionate, and had destroyed me at the time I was born! ${ }^{79}$

Kotzebue not only casts doubt on the legality and humanity of the slave system but also convinces readers that there are white men who do care about the treatment of slaves, "See there, a white man [William], who has humanity...you stand alone among your brethren" 80 by comparing William and John's two contrasting 'ideologies': John, the West Indian planter, who is adamantly opposed to change his attitude towards African slaves and is only interested in profitmaking, and William who has taken more after their father, benevolently respecting his slaves and their cultural values. William rebuts the assumption that Africans transported to the colonies are saved from a worse fate: "They never would have been made prisoners but for you. Their battles are your work. And if the conqueror makes a bad use of his victory, why would you be his accomplice?" 1 He calls his older brother's attention to the fact that slaves are not "just as happy here as there...Then, why do they sigh without intermission after their own country? Why would they chuse rather to live with tigers and lions than with you? Why do they poison and hang themselves? Why out of nine millions of slaves which the new world received, are seven and an half dead?" 82 John also claims that "without us, they never would have known the Christian religion. They exchange their freedom for the salvation of their souls." William counters that he could do away with religion - "If religion sanctifies the crime, away with it for ever!" 83 - but not with the fact that his fortune is built on the misery of slaves: "I blush for every shilling in 
my pocket! every morsel I put into my mouth is embittered by the tears of suffering human nature." 84

(3) From the coloniser's perspective, being a benevolent master entails treating Africans as children whose thankfulness for being educated is to overpower their misery. This preservative strategy of the coloniser/planter helping slaves to intellectual and cultural enlightenment is intensified by the fact that slaves themselves promote this image. William and John's father is exalted by the slaves as someone who cared for his children: "Children, he said, I am going to God." 85 William is the rightful heir to this honourable 'position' as his only goal is to liberate slaves by improving their condition, "I thank you, my children! I will endeavour to mend your lot." 86 With the help of one man, the famous William Wilberforce, he is convinced to free slaves from the shackles of human enslavement, "Have hope, poor men! It will be better with you. There lives a man in England who loves you, who is day and night meditating your relief, and who, warmed with the glorious fire of philanthropy, defends your rights with fervid eloquence... The slave-trade shall cease. No more of your brethren shall be imported here." ${ }^{87}$ William thus directs the reader's attention to England and Denmark, nations known for their philanthropy: "Away from this coast! Whither? To England, into the arms of that man, whose noble heart has made him an orator in the cause of humanity - to Denmark, to the feet of that prince who was the first to break the chains of these unhappy wretches, and who received tears of gratitude for gold." ${ }^{88}$ Kotzebue conjures up the image of the 'father', William in the West Indies and William Wilberforce ${ }^{89}$ in England, who is destined to improve the slaves' lot by raising his African 'children' onto a higher level of human existence. The positivisation of the out-group members by civilising them consequently leads to the negativisation of the same out-group depicted as lacking European cultural values. So while William personifies the redeemer sent to free slaves - "Would to God I could

84 von Kotzebue (1796), 27.

85 von Kotzebue (1796), 31.

86 von Kotzebue (1796), 45.

87 von Kotzebue (1796), 45, 46

88 von Kotzebue (1796), 38.

89 That is maybe the reason why he named William after the famous William Wilberforce. 
give freedom to you all!" 90 - John symbolises the mean and indifferent economist. William eventually gives away half of his fortune to free his 'children' Zameo and Ada, proving his empathy for the oppressed slaves, preparing the ground for their education, and corroborating the 'superiority' of humanity over economic greed, as outlined in William's phrase "Brother, I am richer than you." "91

Kotzebue contrasts the peaceful life of slaves in Africa with the meanness and corruption of Europe reaching its perfection in the West Indies. Ada describes Africa as a country where "we rested together at night on the same woven mat, our sleep was sweeter than that of our Chief on his European carpet. Something was with us, and about us, that breathed serenity and a sense of joy, and to which we knew not how to give a name. It was love!"92 The destructive strategy of dismantling the national identity of Europeans and the transformative strategy of changing the national identity of Africans proves successful as Africans "abhor all meanness," appreciate "hospitality," and believe in "the great God Numbo," a corroboration of their religiosity alongside their culture. Being enslaved and destined to obey the white master until their death, Africans long for a better life ${ }^{93}$ "where Negroes are allowed to be happy [...] the Whites torment us for a season, but when it grows too bad, we have a friend who is no friend to them. He bears a hideous name. He is called Death." 94 Redemption in heaven is what slaves strive for finally putting an end to their oppression and making them stand equally erect beside whites:

Truro. When we shall stand all together, black and white, before

God's throne.

Lilli. When color shall be no more a crime.

Ada. And when Nature again resumes her rights.

Truro. Then shall no Overseer exercise his whip over us!

Lilli. Heaven is sweet! There no sugar-canes are cultivated. ${ }^{95}$

90 von Kotzebue (1796), 65.

91 von Kotzebue (1796), 102.

92 von Kotzebue (1796), 28.

93 "Have you forgot that our soul flies back with the last sigh to its native country? there we shall walk in the cool shades of ever blooming palm trees; there the spirit of my unborn child will meet me smiling!" von Kotzebue (1796), 98.

94 von Kotzebue (1796), 29. "The bread of slavery, moist with bitter tears,/Sustains unwelcome life thro' toilsome years;/Come, kind deliverer, death! Come, 'Misery's Friend!'/Lead to that tranquil home where sorrows end." (37)

95 von Kotzebue (1796), 36, 37 
Freed from constraints of economic greed it seems that categorisation ceases to exist and the in- and out-group coalesce into one uniform group. William goes even further telling Zameo that "It was always my opinion, till now, that God had formed us of the same materials; I was under a mistake, he made you of better." 96 Ada's final statement that she cannot change John's attitude towards slavery, "You cannot wash my face white, or I his conscience," 97 hints at the fact that there is an innate difference between black and white - between Europeans and Africans, between whites as "monsters"98 debasing people they think to be inferior and black people portrayed as loving, peaceful, and loyal - and that the final reversal of roles and the transformation from out-group to in-group and vice versa has not taken place. Kotzebue's depiction of slaves vacillates between the "positive/negative image" characterising Ayos, Truro, and Lilli as "equal human beings but still influenced by Eurocentric paternalism," and the "hyper-positive image" 99 where Zameo assumes the role of the superior African functioning as "foil to European vice." 100 Ada is assigned the role of the obedient wife willing to commit suicide to save her husband from death and to escape John's absolute power over her. Despite the positivisation of the out-group Kotzebue does not succeed in getting across his overall positive image of African slaves in bondage as he is averse to shaking off the paternalist attitude of the benevolent planter (William) ready to educate the inferior and subservient slave(s).

\section{Conclusions}

The analysis of James Miller's Art and Nature (1738) and August von Kotzebue's The Negro Slaves (1796) substantiates the stereotyped view of the dominant British ideology in assessing its relationship towards the 'Other,' identified as the "wildman" from the forest taken to Europe in Art and Nature and the African slaves languishing in the West Indies in The Negro Slaves. The aim of this paper was to uncover the playwrights" attempt to come to terms with "simplified 
and generalised judgement[s]"101 in the slavery discourse - even if Art and Nature was published as early as 1738 - scrutinising the playwrights' attitudes towards enslaving human beings. Allport defines attitude as a "mental and neural state of readiness, organized through experience, exerting a directive or dynamic influence upon the individual's response to all objects and situations to which it is related." 102 Once verbally expressed, attitudes referring to social groups turn into stereotypes. ${ }^{103}$ Stereotypical images of Africans and the 'Other' conjured up in the dominant ideological struggle between Britain and other nations and peoples in the contact zone produced a firm belief in the inferiority of the 'Other' assigning and denying certain qualities to the out-group. ${ }^{104}$ The analysis of the plays has revealed that the two playwrights created images of resistance counteracting the dominant ideology by refuting the prejudice of the 'Other' as "cunning, vicious and stupid" 105 - the act of resisting and/or overcoming predominant prejudices implies deconstructing ethnocentric beliefs with the help of different discursive practices and by discursively affirming the validity of the respective out-group, in the course of the play transformed into the in-group ${ }^{106}$ - but by doing so confirmed the belief in the civilising duty of Europe in educating Africans destitute of culture, religion, morality, and dignity.

In James Miller's Art and Nature the slave Julio is not silenced by 'in-group ideology' but instead assumes an active role expressing his disdain for the "civiliz'd part of the World:"107 Julio accuses Europeans of being not only foolish and ignorant as all their "wisdom consists in the knowledge of the Laws" but also poor and slaves to their possessions which they "prefer to [their] liberty," leading to the oppression of their "Brethren whom [they]'ll hang for taking a trifle of that which is of no use to [them]." 108 Miller creates a romantic notion of nature, reason, and knowledge literally untouched by the fatal machinations of modern civilisation; nevertheless, even if the white

101 Quasthoff (1973), 19. (my translation)

102 Allport qtd. in Quasthoff (1973), 22.

103 See Quasthoff (1973), 27.

104 Quasthoff (1973), 27.

105 von Kotzebue (1796), 24

106 "The acquisition, use, and transformation of ethnic prejudice is a social process in which in-group preference is confirmed discursively." Essed (1991), 45.

107 Miller (1738), 24.

108 Miller (1738), 50 . 
characters listen to Julio's accusations and appeals, he is dismissed as a "simpleton," a "brute," a "natural" to whom it is not worth paying attention. Although his presence in Europe has reduced Julio to "a miserable Slave, faithless, base, inhuman Wretch" - compared to his existence in the woods where he was "at once Master and Servant, King, and Subject" not knowing "Riches nor Poverty"109 - it is only the gap between rich and poor that is of concern to the white characters. The identities of both in- and out-group are evaluated, contrasting liberty with money and corruption, but eventually the outgroup is marginalised by creating a superior 'monoculture' controlling the inferior existence of Julio who is coerced into being thankful for being introduced to corruption and decay. So even if Miller lets Julio denounce the ambiguity in Europe's colonising mission - trying to delude readers into believing that "the voice of nature and reason" may defy the inexorable decline of Europe's morality - by serving the function of the foil to European vice, he uses a preservative discursive strategy to confirm the strong cultural and national identity of Europe at the same time substantiating her unwillingness to return to a state of "nature and reason," instead compelling ostensibly inferior people to adopt her corrupt cultural values. Art and $\mathrm{Na}$ ture stakes out the outgroup by internalising the negative image of the 'savage' from the woods contrasting it with the in-group which pairs British values of money and morality with civilisation to triumph over reason and nature.

August von Kotzebue's The Negro Slaves deals with the atrocities of the slave system denouncing the inhumane treatment of slaves comparing it to the "juice extracted from the palm-tree"110 left to die. Kotzebue succeeds in deconstructing prejudices about African slaves by contrasting the good and bad planter, humanity and economic necessity of trading in slaves, empathy and habit, and in moving readers to sympathise with the slaves by juxtaposing their happy life in Africa with the different stages of being made a slave: captured in Africa and parted from family and relatives, transported to the colonies, sold at the market, and being forced to work on plantations. Kotzebue apportions blame when he makes an African character assert that "from you [the whites] we have learnt to trade in 
men."111 Thus, John controlling Ada's body is a metaphor for Europe's economic interest holding sway over its subjects in Africa. Kotzebue not only claims that Africans are not destined to be slaves - "No man can be born a slave. [...] The liberty of man is invaluable! [...] He belongs to his first master, to God, who never gave him his liberty!"112 - but also asserts that all Europe contributed to the 'making' of slaves. While Kotzebue conjures up images of resistance making William maintain that God "made you of better"113 granting Africans a higher status than whites, he at the same time misses the opportunity to refute the prejudice of Africans being easily pleased when he makes a black character claim that "So little is sufficient to animate the Negro, give him but a bagpipe and a glass of genuine rum, and he will work for weeks together without murmuring." 114 The destructive strategy of dismantling Europe's national identity and the transformative strategy of changing Africa's national identity should have led to the final reversal of roles where the former European in-group is turned into the out-group and vice versa, but Kotzebue's positivisation of slaves as 'superior' human beings combined with the image of Great Britain as the redeemer still has the bitter taste of Europe educating/elevating Africa, 'tainting' the image of resistance with a paternalist outlook.

Miller and Kotzebue created two divergent images of slaves Julio, the 'noble savage', still untouched by the sinister reverberations of civilisation, who, as the "voice of nature and reason," fails to instruct Europeans, and Zameo, the human being entitled to the right of not being treated differently from Europeans - but their images of African slaves still have one thing in common: the subservient slave is in need of being educated before s/he is to be introduced to European civilised life.

\section{Works Cited}

Essed, Philomena (1991): Understanding Everyday Racism. An Interdisciplinary Theory (=Sage Series on Race and Ethnic Relations 2). Newbury Park: Sage Publications. 
Geulen, Christian (2007): Geschichte des Rassismus. Munich: C.H. Beck.

Hays, Michael (March 1995): "Representing Empire: Class, Culture, and the Popular Theatre in the Nineteenth Century," in: Theatre Journal 47 (1), 65-82.

Jäger, Siegfried (1993): Kritische Diskursanalyse. Eine Einführung. Duisburg: DISS.

Jäger, Siegfried (2001): "Diskurs und Wissen: Theoretische und methodische Aspekte einer kritischen Diskurs- und Dispositivanalyse," in: Keller, Reiner/Hirseland, Andreas/Schneider, Werner/Viehöver, Willy, eds.: Handbuch Sozialwissenschaftliche Diskursanalyse. Band I: Theorien und Methoden. Opladen: Leske und Budrich, 81-112.

Knapp, Adrian/Pallua, Ulrich (2008): "Images of Africa(ns): Racism and Ethnocentricity in the British Abolition Debate: 1787-1834," Innsbrucker Diskussionspapiere ₹n Weltordnung, Religion und Gewalt 26, University of Innsbruck.

Kotzebue, August von (1796): “The Negro Slaves, A Dramatic-Historical Piece, in Three Acts," in: The English Prose Drama Full-Text Database. Chadwyck-Healy Ltd. 1996-1997.

Miller, James (1738): "Art and Nature," in: Literature Online. American Drama Full-Text Database, University of Innsbruck (2007), online at http://lion. chadwyck.co.uk (accessed on 24.10.2008).

Quasthoff, Uta (1973): Soziales Vorurteil und Kommunikation - Eine sprachwissenschaftliche Analyse des Stereotyps. Ein interdisziplinärer Versuch im Bereich von Linguistik, Sozialwissenschaft und Psychologie. Frankfurt/M.: Athenäum Fischer Taschenbuch Verlag.

Reisigl, Martin (2000): "Cuius ops, eius lingua. Forms of Linguistic Imperialism," in: Reisigl, Martin/Wodak, Ruth, eds.: The Semiotics of Racism. Approaches in Critical Discourse Analysis. Vienna: Passagen Verlag, 199219.

Reisigl, Martin/Wodak, Ruth (2001): Discourse and Discrimination, Rhetorics of Racism and Antisemitism. London: Routledge.

Van Dijk, Tuen A. (1987): Communicating Racism. Ethnic Prejudice in Thought and Talk. London: Sage.

Van Dijk, Tuen A. (1993): Elite Discourse and Racism. Sage Series on Race and Ethnic Relations. Vol. 6. London: Sage.

Van Dijk, Tuen A. (2001a): "Multidisciplinary CDA: a Plea for Diversity," in: Wodak, Ruth/Meyer, Michael, eds.: Methods of Critical Discourse Analysis. London: Sage, 95-120.

Van Dijk, Tuen A. (2001b): "Critical Discourse Analysis," in: Schiffrin, Deborah/Tannen, Deborah/Hamilton, Heidi E., eds.: The Handbook of Discourse Analysis. Oxford: Blackwell, 352-371.

Wodak, Ruth/Reisigl, Martin (1999): "Discourse and Racism: European Perspectives," in: Annual Review of Anthropology 28, 175-199. 
44 Discursive Strategies in Confirming Images of Power

Wodak, Ruth/Reisigl, Martin (2001): “Discourse and Racism,” in: Schiffrin, Deborah/ Tannen, Deborah/Hamilton, Heidi E., eds.: The Handbook of Discourse Analysis. Oxford: Blackwell, 372-397. 
Silver Service Slavery: The Black Presence in the White Home

Helen Mears

\section{Introduction}

The black domestic servant has been described as a "hallmark" of eighteenth-century English urban life, "a sought-after possession and a motif in contemporary paintings, textiles, prints, porcelain, and poetry." 1 In the visual culture of the period, the servant is typically pictured as a boy or young man, in elaborate orientalist dress (or, at the very least, a feathered turban ${ }^{2}$ ), against a backdrop of affluent domesticity. His is always a bit part and he is generally positioned near the wings, in isolation, whilst white subjects play out the focal activity at centre stage. Paul Kaplan has suggested that an early referent for this figure may be the black attendants who appear in the retinue of the Magi in fifteenth and sixteenth-century Italian scenes of the Adoration. ${ }^{3}$ In these images the black figure is similarly decoratively attired, providing the artist with an excuse for some orientalised detail whilst symbolically serving to demonstrate the universal reach of Christendom. The figure is then developed in the European portrai-

1 Molineux (2005), 498.

2 Beth Tobin notes that, in the eighteenth century, the black servant is usually pictured "dressed in livery and [wearing] either a turban or a skullcap. Both head coverings are exotic and allude to the Turkish, Moslem, and Mughal cultures of the Levant, northern Africa and the Indian subcontinent. This conflation of Arabic, African and Indian origins is typical of many $18^{\text {th }}$-century representations of black servants. What seems to matter is not that these servants are African, Muslim, or Indian, but that they are exotic, that they originate in tropical, fertile, and remote lands." Tobin (1999), 27.

3 Kaplan (1982). 
ture tradition, where a black boy (sometimes girl), posed in an attitude of fawning devotion, acts as aesthetic foil to the European subject's white skin, as testament to their wealth and taste and more broadly as symbolic of the West's 'civilising' of the dark continent, a service figuratively rewarded by the servant holding up Africa's 'natural riches' in the form of an emblematic offering. Examples of such portraits include Titian's painting of Laura dei Dianti (c.1523), Van Dyck's of Princess Henrietta of Lorraine (1634) and Pierre Mignard's of the Duchess of Portsmouth (1682).

These visual traditions respond to the presence of African slaves in European courts in the fifteenth and sixteenth centuries. Like the painted portraits which depicted them, these individuals existed within an orbit of rarefied exoticism, and were visible only to a select few. In contrast, Britain's growing mastery of transatlantic trade in the eighteenth century brought increasing numbers of black Africans to its shores, where they joined the ranks of a small but significant, largely urban, black population. Estimates of the size of London's black population in the later part of the century vary between $5,000^{4}$ and $20,000^{5}$ and it is clear that it was a population well integrated with the wider white community. Many black individuals worked as domestic servants, but others as sailors, shopkeepers, artisans, labourers, peddlers and street musicians, amongst other professions. Yet in the visual culture of the period the diversity of lives and experiences of Briton's black subjects was to a significant extent symbolised by a single image: that of the black domestic servant. Moreover, through exploiting new technologies of manufacture, this reductive image drew strength from its endless reproduction onto cheap domestic goods, the proliferation of which enabled it to enter a broader spectrum of homes than ever before.

In what follows I argue that the image of the black domestic servant as it multiplied on the material culture of the eighteenth century served to fulfil the role of stereotype, harnessing the black subject to a role of enduring infancy and subservience. That the image was ubiquitous in the eighteenth century - a period in which abolitionist

4 Myers (1996), 27.

5 "The practice of importing Negroe servants into these kingdoms is said to be already a grievance that requires a remedy, and yet it is every day encouraged, insomuch that the number in this metropolis only, is supposed to be near 20,000," writer to The Gentleman's Magazine, 1764, quoted in Gerzina (1995), 41. 
campaigning grew from a murmur to a din - suggests that its appearance may have been associated with increasing public awareness of the realities of transatlantic trade. In this respect the image serves both as stereotype and fetish; the black subject providing a visual reminder of the victims of enslavement while his youthfulness and petted status disavow the physical horrors of the slave trade.

Homi Bhabha has defined the stereotype as "an arrested, fixated form of representation" embodying "a form of knowledge and identification that vacillates between what is always 'in place', already known, and something that must be anxiously repeated." 6 Thus whilst the innate servility of Africans as a less 'developed' race might have been established in contemporary discourse, the "anxious repetition" of the image of the orientalised black child servant in decorative art of the period ensured fixity. This fixity served to lock black subjects into roles of subservience both on the domestic scene - 'at home' and in Britain - and, through the increasing export of Britain's new 'world of goods' to Europe and the United States, on a global platform.

In what follows I explore, through a series of key images, how the stereotyped image of the black domestic servant was established and deployed. Much of the initial part of this paper addresses the legacy of William Hogarth, an artist hailed for his compassionate treatment of black subjects who appear in many of his works. This has stimulated considerable literature on the subject, not least David Dabydeen's seminal Hogarth's Blacks, which celebrates the complex and sympathetic ways black subjects were utilised in Hogarth's images. ${ }^{7}$ However, the fact that black figures feature in all of Hogarth's major satirical series, from the Harlot's Progress of 1732 to the Election pictures of the 1750 s, but to a lesser extent in his conversation pieces, implies satiric intent rather than realism in the ways in which these subjects are employed. This intent relies for its success on common recognition of the stereotypes used in its construction and while the image of the black child servant may have already been in circulation, Hogarth's work demonstrates a more sophisticated use of the stereotype: it was the image of the black servant as conceived 
by him which would come to feature on the multiplying forms of eighteenth-century material culture.

While the medium of print ensured a wide circulation for Hogarth's black subjects, from the 1750s onwards the new technique of transfer-printing meant that iconographically-loaded ceramics were available to an ever-broadening range of consumers. The fact that an engraved design of a tea party featuring a young black page became the most popular transfer-printed design of the century attests to the wide appeal of this figure. That transfer-printed ware was viewed as "the market leader of a new international commodity" also suggests the importance of the motif of the black servant to notions - and representations - of the national self. ${ }^{8}$

After abolition the motif of the black servant largely disappeared from view, only to re-emerge in the late twentieth century in the work of a number of young black British artists who found it an apt visual metaphor for their own sense of creative marginalisation. In the final part of this paper I look at the reappropriation of the image of the black servant by Yinka Shonibare and Lubaina Himid, both of whom sought to recover the figure of the black domestic servant from its eighteenth-century origins and reinvest it with narratives of agency, subjectivity and resistance. In addressing the stereotype, both artists also chose to respond to the legacy of William Hogarth, pointing again to his influential role in its creation.

If, as I suggest, the image of the black servant served as a stereotype, then what were the contexts that enabled and needed it to function as such? As Bhabha has shown, ambivalence is key to the stereotype's effective use; it is ambivalence "that gives the colonial stereotype its currency: ensures its repeatability in changing historical and discursive conjunctures [and] informs its strategies of individuation and marginalization." 9 Before we turn to Hogarth's persuasive picturing of the figure of the black domestic servant, we must consider the social, legal and political contexts against which it was formulated. 


\section{The Ambivalence of the Stereotype}

As Bhabha has observed, the stereotype is shot through with "the force of ambivalence." 10 In the eighteenth century this ambivalence was supplied by the precarious legal status of black Africans in Britain, an issue that preoccupied the nation's law courts throughout the century. Despite some landmark legal cases which paved the way for abolition in the early nineteenth century, throughout most of the eighteenth century black Africans in Britain were largely viewed through the spectrum of slavery. As Norma Myers notes, "As late as 1785 black people continued to be regarded and indeed, treated as property." 11 This created something of a contradiction for the avowedly liberty-loving British public, for, as James Walvin has highlighted, whilst slavery might have been tolerated, even sanctioned by the British public when it happened 'out of sight', on British ships, at African trading ports and throughout the British colonies,

[...] what happened to slaves when they set foot in Britain? For a nation which took great pride in its thriving and expanding domestic liberties, secured by the seventeenth century, it seemed odd, to put it mildly, that the British could countenance slavery surviving in Britain itself. There was a clear confusion of practice between the rise of domestic liberties and the expansion of colonial slavery. ${ }^{12}$

The position of those black Africans brought to Britain as servants was especially unclear as the law neither clearly recognised the legality of slavery, nor granted them freedom from it. Some black servants may have had free status but most were probably unpaid and at the mercy of their masters. No direct testimony remains which would clarify the divisions between black servant and black slave or illuminate details of the lives of either. The stereotyped image of the black child servant is thus fuelled by this ambiguity.

There is further ambiguity in the relationship between the stereotype and 'fact'. It is tempting to excavate from the image of the black servant evidence of some sort of historical 'reality', particularly

10 Bhabha (1983), 18

11 Myers (1996), 41. Myers notes that this is confirmed by the case of Jones versus Schnell which ruled that ship owners be compensated for the loss of Negroes killed, or who died as a result of wounds inflicted during a mutiny of the crew at sea.

12 Walvin (2001), 11. 
given the limited evidence relating to Britain's black presence. However, as Bhabha reminds us, to understand the power of colonial discourse, "it is crucial to construct its regime of 'truth', not to subject its representations to a normalizing judgement"13 and to use these images uncritically as illustrative of 'history' risks further buttoning the eighteenth-century black Briton into this stereotyped cast. Instead the image of the black servant should be considered part of colonial discourse - an apparatus of power - the dynamics of which require careful unpicking.

Stereotypes engender, Bhabha warns, an "effect of probabilistic truth and predictability [...] always [...] in excess of what can be empirically proved or logically construed." 14 While a relationship between the stereotype and fact may be discerned - in the case of the image of the young black male servant Myers notes that in the eighteenth century the domestic service sector remained the largest employer of the black population (as it did of the white) and "the black demographic profile remained both young and overwhelmingly male in its composition and structure" 15 - it is unclear to what extent the stereotype, or the ethos of slavery, has informed this relationship. But this basis in apparent 'fact' gives the stereotype strength and normalises the unnatural power relations presented in these images.

However, the stereotype may also serve to underline the unnatural power relations that have brought it into existence. In a 1732 print by Hogarth, the artist used the figure of the black child servant to highlight a causal chain of brutality and exploitation. The black page proved a popular device, reproduced, as we shall see, in other contexts, but what was it that was so persuasive about Hogarth's picturing of this character, so as to ensure, to reiterate Bhabha, its "repeatability in changing historical and discursive conjunctures"?

\section{The Legacy of Hogarth}

A black child servant appears in plate II of Hogarth's popular satirical series, A Harlot's Progress. (Image 1) Hogarth's inspired marketing scheme of reproducing his original series of six paintings as a set of engravings to be sold by subscription ensured the scene was widely 
reproduced including in other media, such as on a Meissen porcelain plate. ${ }^{16}$ The series tells the story of Mary (or Moll) Hackabout, a simple country girl who arrives in London seeking work, presumably as a servant. Instead she is drawn into prostitution, is arrested and eventually dies of syphilis. In plate II Moll and her lover are surprised by her wealthy master. She attempts to cause a distraction by knocking over a table of tea things, enabling her lover to escape. The black servant, in feathered turban, kettle in one hand, goggles at the scene.

Image 1: William Hogarth. A Harlot's Progress, Plate II, 1732

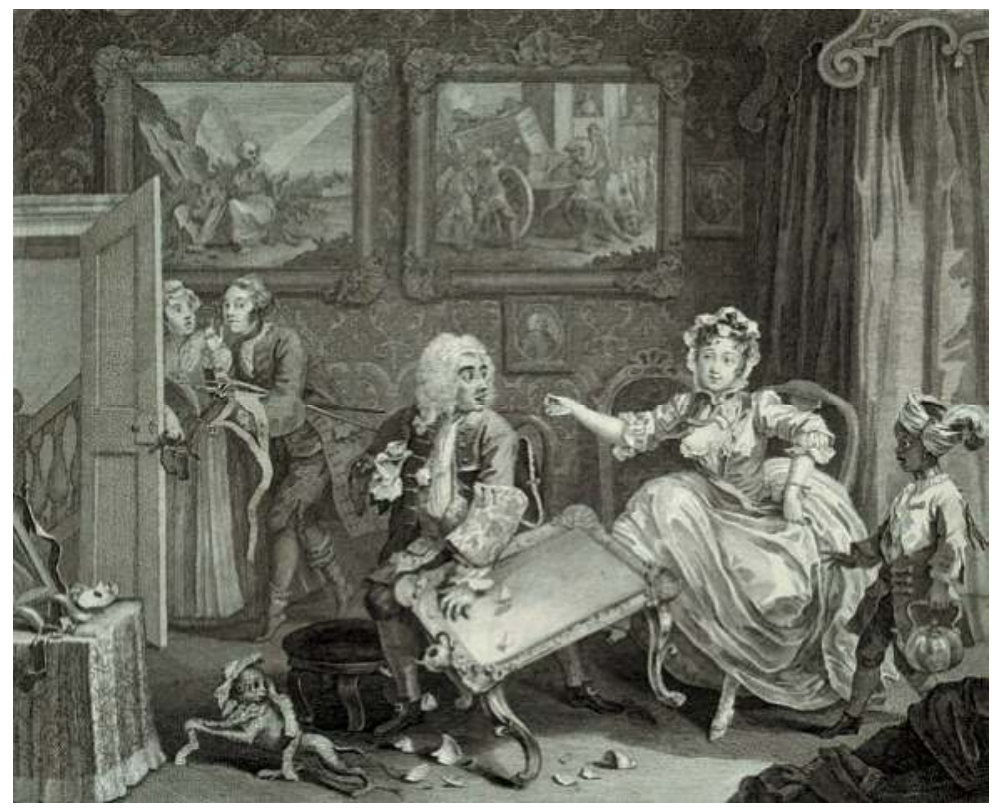

Source: Courtesy of Victoria and Albert Museum, London.

The figure of the black child is familiar from the European portraiture tradition and his presence similarly testifies to the affluence and fashionable taste of his master and mistress, but here the earlier attitude of adoration has been replaced by a stiff upright pose and an 
expression of shock at this scene of immorality. While dressed decoratively, it is clear that his purpose is rhetoric and plays an important part in the unfolding satire. David Dabydeen has tied the boy into a narrative of slavery which he finds operating throughout the Harlot's Progress series; a narrative made explicit in this image through the boy's dehumanising silver 'slave' collar. His presence suggests that Moll too has become a slave, not only to her merchant master but also to luxury and fashionable living. Dabydeen notes the source from which the material evidence of luxury derives; "The merchant [...] who patronises whores, does so from wealth derived from colonial trade (the black boy with his tea-kettle, the monkey and the mahogany table indicate this much)." 17 Both the boy and Moll are aliens within this affluent metropolitan environment - Moll because of her rural origins and the servant because of his African heritage - but they are drawn into the scene through commercial exploitation. According to Dabydeen, the series "describes the human degradation resulting from the commercial spirit operating in society."18 "The cash nexus," he notes, replaces "human relationships, and the "progress' of Moll Hackabout exemplifies the brutal materialism of the Age." 19

Catherine Molineux in her discussion of Hogarth's work similarly finds evidence of "an apprehension with changing consumption patterns" and suggests Hogarth's use of black figures is intended to "connect discourses of consumption with discourses of bondage." 20 For Molineux, Hogarth's primary concern is "not the oppression of black slaves [which, as others have observed, would be anachronis$t^{2}{ }^{21}$, but rather the harmful effects that he perceived in his fellow Londoners' desire for foreign goods". ${ }^{22}$ In her analysis the image of the black servant is rewritten by Hogarth to act as "an empty icon of

17 Dabydeen (1987), 108.

18 Dabydeen (1992), 47.

19 Dabydeen (1992), 47.

20 Molineux (2005), 495

21 As David Bindman has noted, the artist may have "shared unease about the motives of slave traders and the common belief that slavery often led to cruelty, but since the morality of the slave trade became a subject for national debate only a few years before Hogarth's death, the onus of proof that he might have had principled objection to the slave trade is on those who believe that he did." Bindman (2001), 260.

22 Molineux (2005), 495. 
fashion and socio-sexual corruption," 23 a satirical riposte to the tradition of including a black servant in European portraits which represents these "master-slave relationships as virtuous and civilising." ${ }^{24}$

This relationship between the figure of the servant and patterns of consumption, particularly of colonially-sourced goods, is indicated visually in the alignment between the boy, the table, the tea things and the monkey in the picture's foreground. That Hogarth positioned black servants within a culture of commodification is evidenced by another print, Taste in High Life (ca. 1746), which viciously satirises the clothes and behaviour of fashionable society in the early 1740s. (Image 2) All four figures depicted wear ludicrously debilitating dress, emphasising their physical enslavement to fashion. The central female figure wears an excessively large hooped skirt, her companion displays a huge fur muff and long pigtail and the black boy servant, again in feathered turban, is dressed in a coat with tails so long he would surely be prevented from walking. Pictures on the wall behind show further punishing contrivances for creating a fashionable figure. The room is full of collectibles and whilst the couple admire a miniature teacup and saucer, a third woman admires the seated black child. Here it is she who adopts the attitude of fawning devotion while the black boy smiles knowingly. His expression, combined with the position of her hand which touches his chin, suggest the unsettling intimacy to which a domestic servant could be subjected. The gesture and the presence of the squirrel in the foreground (like the monkey previously) place the boy within a hierarchy of 'pets'.

These two images demonstrate Hogarth's adopting the stereotype of the devoted black servant only to invert its previous associations for satirical purposes, in particular to comment upon the enslaving, alienating and morally corrupting effects of consumption, especially of 'foreign' goods. In presenting the black servant as a form of commodity Hogarth was reflecting a strand of contemporary thought which viewed black servants as luxurious frivolities. An "F. Freeman" writing to the London Chronicle in 1765 complained that "Negro and East India servants [...] of late years are become too abundant in this kingdom." He added, 
It may be serviceable to invite over those who practise useful arts, because we are benefited by their skill and labour; but it as far otherwise with menial servants, or the mere instruments of our pleasures and amusements, as while resident here they live on the common stock, and when they go from us they lessen it; therefore they stand in the way of more profitable and useful natives, and serve to obstruct a far better population. ${ }^{25}$

Image 2: William Hogarth. A Taste in High Life, ca. 1746

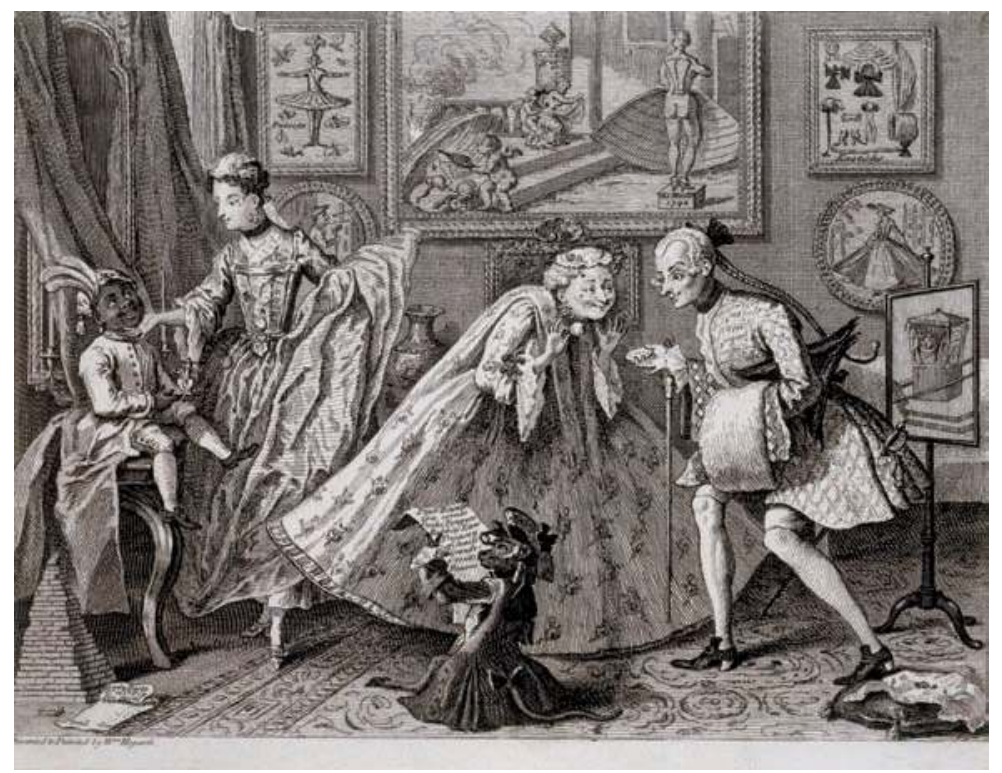

Source: Courtesy of Victoria and Albert Museum, London.

The visibility of Hogarth's images further augmented the stereotype of the black servant as a decorative motif and rhetorical device and encoded it within a semiotic system where its appearance was linked to a critical discourse on the consumption of foreign goods. In Moll's parlour the black servant's silver collar implicitly links the presence of colonial commodities in this affluent domestic interior with the otherwise distant dark realities of transatlantic trade. 
Hogarth was not alone in his concern about the potentially destabilising effects of colonial commodities on the political, social and moral health of the nation; as Beth Tobin has observed, the consumption of exotic luxury goods in the eighteenth century was not "an ideologically neutral activity." 26

Nowhere was the stereotype of the black servant more anxiously repeated than in scenes around the tea table and in connection with its material culture. This is evident in both images: In Moll's parlour the upset table causes an expensive tea service to crash to the floor with the exception of a teacup rescued by the merchant, which mirrors the head of the servant who is already associated with the tea things through the kettle he holds. In Taste in High Life a visual analogy is made between the couple admiring a teacup and saucer and the woman admiring the black child.

Tea and ceramic tea services from China became available in England in the late seventeenth century but it was during the eighteenth century that the popularity of tea-taking grew, initially amongst the affluent and then, by the end of the century, the populace at large. As a social ritual it became an important part of 'polite' society and all respectable homes were expected to possess a set of tea wares. Chinese tea was accompanied by West Indian sugar, the presence of which invoked the spectre of the slave labour that lay behind its production and threatened to de-stabilise this most civilised of rituals. So too did the 'polite' conversations which took place around the tea table, for through conversation the outside world was brought into the domestic interior and the topics of the transatlantic trade and slavery were increasingly 'on the table' as the eighteenth century progressed. This is borne out by the publication of William Cowper's poem "The Negro's Complaint" in 1788, "which his abolitionist friends in London 'ordered ... on the finest hot-pressed paper, and folded it up in a small and neat form, [and] gave it the printed title of "A Subject for Conversation at the Tea-table"."."27

This ambivalence between the civilised ritual of tea-taking and the exploitative trading practices on which it rested is embodied in the figure of the black servant, whose appearance thus serves as a fetish, both recalling the knowledge of slavery and disavowing its cru- 
elty by presenting the black African as a petted child servant, fixed within the hierarchies of people and things in the British domestic interior. In this way the tension posed by an awareness of colonial slavery and the black presence in Britain is 'relieved' by the repetitive re-presentation of the familiar and unthreatening figure of the black child. That this figure appears most frequently at the site of anxiety the tea table - is thus no coincidence.

Image 3: Tea bowl and saucer featuring Robert Hancock's design, The Tea Party, Worcester, $1756-1757$

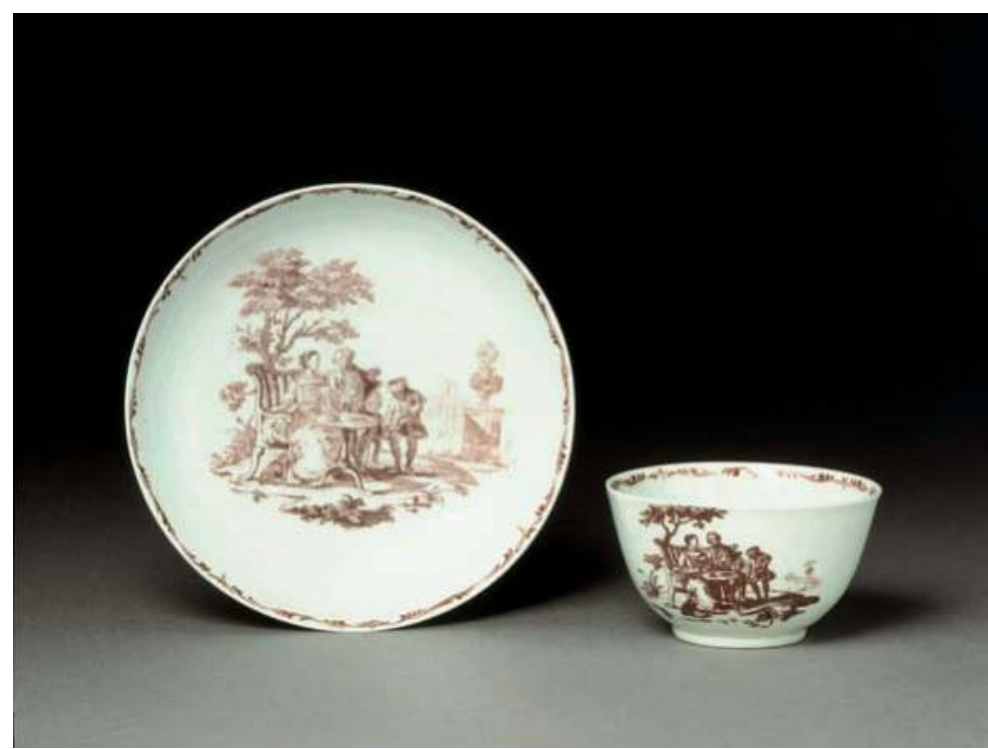

Source: Courtesy of Victoria and Albert Museum, London.

As the popularity of tea-taking grew so too did the demand for tea utensils, which became part of the new world of goods available to eighteenth-century consumers. Demand led to improvements in the production of ceramic ware, adding to its desirability as a medium encapsulating both refinement and technology. In particular, the new technique of transfer printing enabled the production of a greater number of iconographically-loaded artefacts than ever before. Through this technique high-quality images could be printed onto ceramics and reproduced in quantity, saving time and making 
porcelain more affordable to a large part of the populace. The technique was most extensively used at the Worcester Porcelain Factory, particularly by the engraver Robert Hancock.

The most popular of all on-glaze transfer-printed designs was one by Hancock known as The Tea Party, which, in its most common version, includes a black child servant. ${ }^{28}$ (Image 3) This image was used on tea-taking paraphernalia by a number of ceramic manufacturers around the period 1750 to 1780, including Worcester, Staffordshire, Bow and Wedgwood. The design depicts a fashionable and well-dressed couple sitting on a high-backed settee in a garden setting with a table of tea things in front of them. While a turbaned black boy servant bows slightly on one side of the settee as he pours water from a kettle into a teapot, the composition is balanced by the figure of a seated dog positioned on the other side of the settee, again suggesting the 'petted' status of both.

Eighteenth-century engravers were prolific plagiarists taking designs and design inspiration from a wide range of sources. Hancock was particularly indebted to the French designer Louis Peter Boitard and the Tea Party image is greatly influenced by the French style. However, the exact source for the design has not yet been identified and none of Hancock's original engravings have yet been traced. Hogarth may well have been used as a source for the figure of the black servant for he, like Moll's, carries a kettle and is dressed in a similar fashion down to the tassel hanging down his back. That Hancock was aware of Hogarth's black servant becomes apparent when considering a design often associated with other versions of The Tea Party in which the couple is shown without the servant. The associated design, entitled The Maid and Page, was used to decorate the opposite sides of bowls and pots. The sources of these figures are well-known: the maid was taken from the image Playing the Game of Quadrille designed by Hubert-François Gravelot for execution by the studio of Francis Hayman. ${ }^{29}$ In Quadrille, a maid and young black male servant (again holding a kettle) stand over a table of tea things, looking towards the central activity, a fashionable group playing cards. Curiously, Hancock did not reproduce this black servant but opted for Hogarth's figure instead. The servant from Moll's parlour

28 The Tea Party design appears in at least three versions and was widely copied.

29 The full-sized Hayman work was one of fifty or so pictures that furnished the walls of the 'supper boxes' at Vauxhall Gardens. 
is reproduced unchanged, even though, as Lars Tharp observes, "the scene into which he has been dropped [...] - showing a maid arranging a tea table out of doors - should give no cause for alarm Hancock leaves the expression of surprise unaltered: note the outstretched, splayed fingers as well as the startled eyes." ${ }^{30}$

That Hogarth's black child servant could be so readily 'lifted' with disregard for context demonstrates the effectiveness of the stereotype, which, as an "ambivalent mode of knowledge and power," is normalised through reproduction. Moreover, transfer printing enabled the "anxious repetition" and consumption of the stereotype on an increasingly large scale. It also facilitated the fetishistic reproduction of images of black servants pictured within scenes of tea taking, upon objects designed for use in this ritual. To disavow the spectre of slave labour the increasing fixity of the image within this semiotic system produces

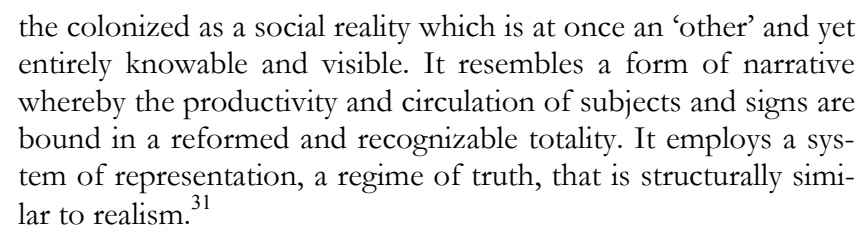

the colonized as a social reality which is at once an 'other' and yet entirely knowable and visible. It resembles a form of narrative whereby the productivity and circulation of subjects and signs are bound in a reformed and recognizable totality. It employs a system of representation, a regime of truth, that is structurally similar to realism. ${ }^{31}$

Given the persuasive qualities of stereotypes, which through their "system of representation" and "anxious repetition" begin to assume the shape of "truth", it is not surprising that the image of the black servant persisted after the issues driving its creation and use were considered to have been dispelled. In particular, the image of the black servant caught the imagination of members of a generation of black British artists who found in it a reflection of their own sense of marginalisation and isolation within the British art scene. These artists reinterpreted the figure of the black servant from a postcolonial perspective opening up new readings and interpretations that challenged the fixity and ambivalence of the stereotype. In the remaining part of this paper I highlight works by two artists who resisted reductive readings of the image and instead found ways to excavate narratives of agency, subjectivity and resistance. 


\section{Afterlife: The Black Servant in Contemporary British Art}

In 1998 Yinka Shonibare created a series of five photographic images loosely based on Hogarth's Rake's Progress series (ca. 1735). The photographs were based on a performance which took place over three days in a stately home in Herefordshire. Diary of a Victorian Dandy traces a day in the life of a dandy from 11am to $3 \mathrm{am}$. The context was shifted from the eighteenth to the nineteenth century to emphasise the connections between these scenes of affluence and consumption and the reign of British imperial ambition, especially poignant for Shonibare as a British-Nigerian. Another fundamental shift took place in Shonibare casting himself in the central role of the dandy around whom each scene revolves, which apart from him comprises exclusively white actors. (Image 4) As if the act of subversion were not obvious enough, the day starts with him in bed, surrounded by five members of his devoted white domestic staff. As Shonibare recently commented,

I chose Hogarth for his social commentary and the political aspect of his work. He had a very interesting relationship to authority. My series is a commentary on our times, but it is also about daring to parody the establishment - which was something Hogarth was very good at - as a black person. There is a historical representation of black people as less powerful, especially in art, they are usually depicted as subservient or as victims, so what I am trying to do here is reverse the roles. ${ }^{32}$

A series by Hogarth similarly provided a starting point for an installation by Lubaina Himid in 1986. In her case it was the series Marriage A-la-Mode, which in six scenes describes the fallout from an arranged marriage between the son of an impoverished earl and the daughter of an avaricious tobacco merchant. Himid focussed on scene four in which the young countess is pictured at her toilette receiving the attention of her lover, the lawyer Silvertongue, surrounded by sycophants and parasites of the beau monde. Two black servants attend the scene; one, a turbaned child, kneels beside a basket of auction house booty. He points knowingly to the horns of a statue of Actaeon, indicating that the absent earl is to be cuckolded. The other black servant, a young man, serves hot chocolate to the 
countess whilst barely able to conceal his shock at the debauched activities happening around him.

Image 4: Yinka Shonibare, MBE. Diary of a Victorian Dandy: 11.00 hours, 1998

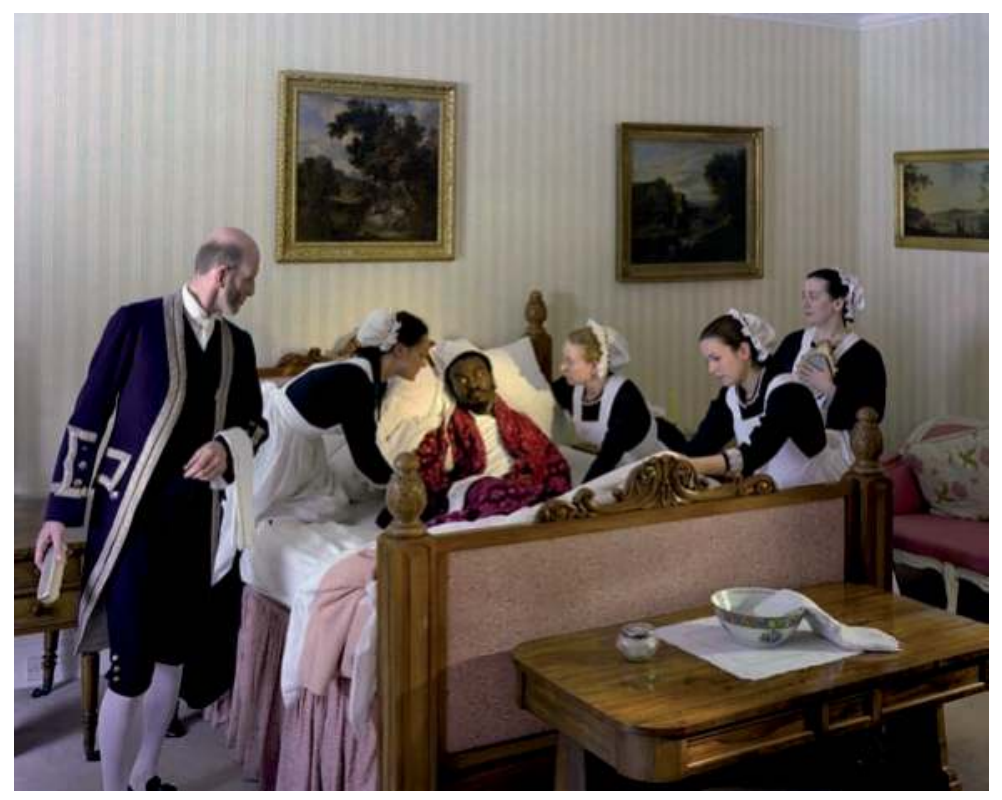

Source: Courtesy of the artist, Stephen Friedman Gallery, London and James Cohan Gallery, New York

As a black woman and feminist, Himid was drawn to the economies of race and gender played out in Hogarth's scene which she transformed into a multi-media installation entitled $A$ Fasbionable Marriage. In her installation each character from the scene was reproduced as freestanding, larger than life, plywood figures shaped, painted and positioned around a room in a similar spatial relationship to Hogarth's original. However, Himid's reinvention of the work went further than a mere change of media; Himid also recycled Hogarth's eighteenth-century illustration of the increasing commodification of life - where the arts were "purchased for show, rather than enjoyed for themselves" and women and black people could be bought and sold - to expose the "political stranglehold" the right 
wing had on the country and the complicity of the "middle-class, complacent, liberal intellectual art community." 33 Correspondingly, the installation becomes a diptych: The Art World on the left and The Real World on the right. In the latter, the countess and her lover are reincarnated as Margaret Thatcher and Ronald Reagan in an attempt to satirise the British leader's "political fornication with the smoothtalking leader of the imperialist world". 34

Crucially, the two figures apparently most peripheral in the Hogarth work are brought to the centre in Himid's interpretation. To a casual eye the two black servants appear marginal on many levels;

they are black; they belong to the servant class; they have no role in the main action; and they are depicted on the margins of the social circle and of the picture [...] The youth offering chocolate is at the very back of the room [...] He bends forward in a respectful attitude and his body is only half visible. The second, still a child, is in the foreground, but he is playing by himself and is not involved in the socialising that goes on in the room. ${ }^{35}$

Bernadette Fort further notes, "Himid, however, casts on Hogarth's painting a different, post-colonial, gaze that not only valorises the two black servants, but transforms them into the main protagonists". She reinvests the black boy servant with a central role; interpreting

him as a key figure, both an insider to the world of the Countess and the mediator between the fictional world of the image and the real world of the beholder. She endows him with knowledge and narrative agency. He can tell what the image does not show, the secrets of the alcove and the ambitions of all the players. He knows the beginning and he knows the ending of the story, and, with his own panoply of toys, like a puppeteer in a show, he can convey this meaning to the viewer [...] Instead of the colonialist figure of the exoticised and objectified black slave, Hogarth's page boy becomes for Himid the only participant in the scene who is endowed with knowledge and foresight. As such, he is a figure of the artist. ${ }^{36}$ 
Image 5: Lubaina Himid. Fashionable Boy Servant 1743 / The Radical Activist 1986, 1986. Working drawing for the installation A Fashionable Marriage

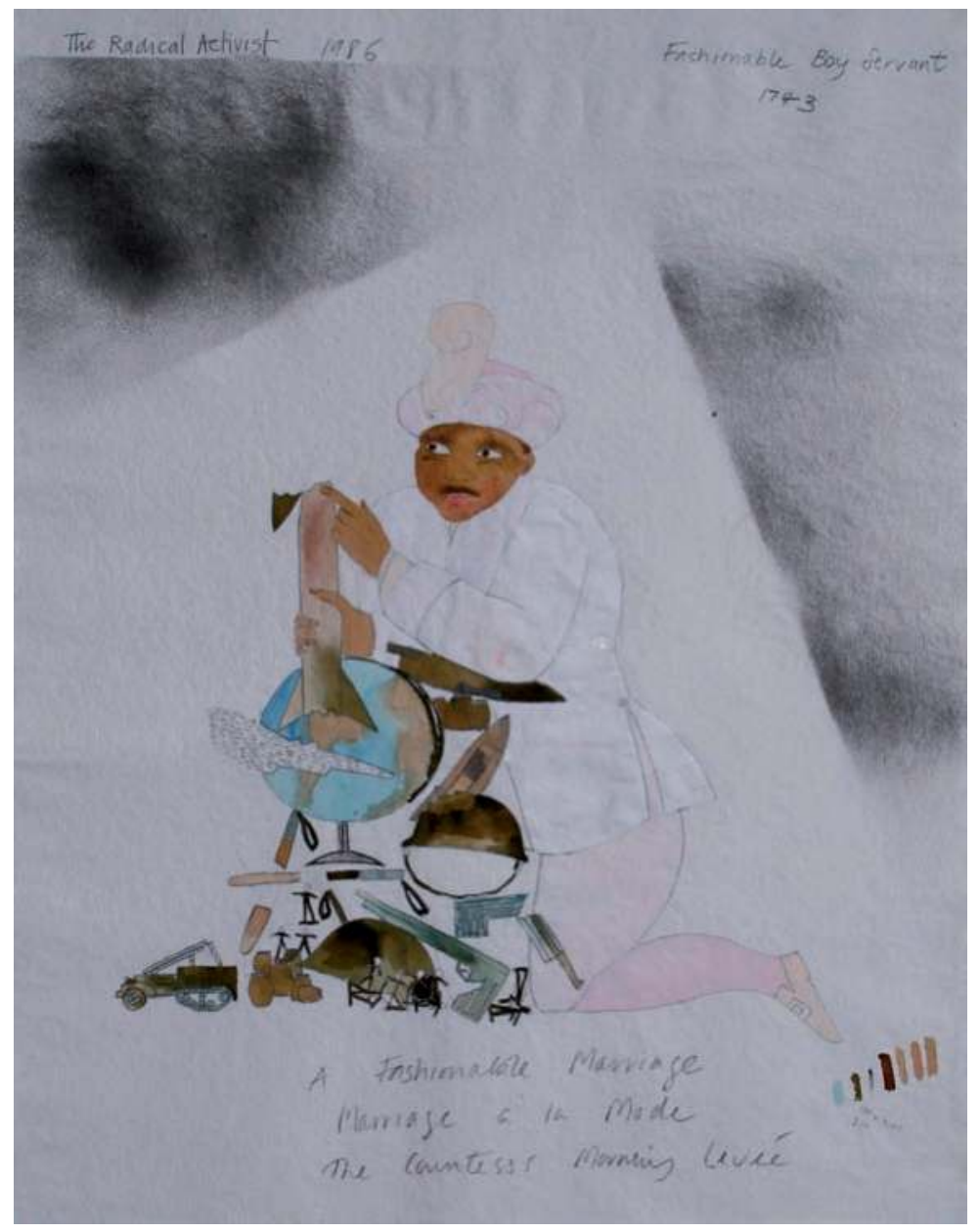

Source: Courtesy of the artist, Victoria and Albert Museum, London.

Himid's revisioning of Hogarth's black boy servant is represented by one of a series of drawings created as studies for the cutout figures and used as guides during their production. The drawing is of a young black man in orientalist dress, who kneels next to a 
globe and a pile of 'war toys', including batons, helmets and guns. He points to the top of a rocket which he has defused by breaking off the tip. (Image 5) In contrast to Hogarth's apparently subordinate boy servant, this African man is explicitly insubordinate and world security is held within his palms. However, in Himid's final installation the black boy servant becomes a black girl who sits on a suitcase, a roll of film at her side, guarded by two fierce dogs. Unlike Hogarth's black servants who are victims of representation, Himid's girl is fully aware of the connections between "media, representation and power ... The slave boy's preoccupation with sex toys became the sober mistressing of modern visual technology." 37 Similarly, the black adult who serves a cup of hot chocolate is transformed in Himid's work into a pivotal figure who completely dominates the installation. Here, she is a black woman artist; "[s]he had a larger offering and poured it towards the eager listener: energy." 38

In repositioning Hogarth's black servants as central to the action, "politically active, [...] knowing intelligent catalysts of change and revolution," Fort suggests Himid is following Griselda Pollock's strategy of 'differencing'. ${ }^{39}$ This strategy seeks to take "revenge on the cultural canon in which the colonial relations have been inscribed."

Revenge involves a form of quotation and reconfiguration that aims precisely to make possible a historically informed practice of painting $[\ldots]$ a new form of history painting necessitated by the urgent need to explode the Western myth of Africa which contributes to the erasure of a creative subjectivity for the artist of African descent. ${ }^{40}$

In revisiting Hogarth's image and recovering the subjectivity and agency of the black servants pictured there, Himid also reclaims a space and agency for herself as a black Briton and a black woman artist. As bell hooks has noted in her theorising on film, black women, when represented at all, run the risk of appearing as "servants to white people." In reversing the racial and gender economies visible in Hogarth's work, Himid counters the "myth of an exoticised, 
eroticised, and objectified Africa that lurks at the back of the Western artistic canon [...] with the image of the knowing and selfpossessed African artist, who builds on a rich cultural legacy." 41

\section{Conclusion}

Against the evidence of significant, well-established and, at least locally, well-integrated black British populations, the image of the black domestic servant as it appeared on the multiplying forms of eighteenth-century material culture served to fix the black subject into a role of enduring infancy and subservience. That this took place at a time of nation building is significant, for, as Kathryn Wilson has observed, "the place of Africans [...] in the national imaginary was fraught and uncertain." 42 As she has noted, establishing a homogenised national identity relied on a process of marking out - and containing - the threat of difference;

[If] discourses of nationality sought to construct homogeneities within the territorial boundaries of the nation-state, they also sought to identify and assert difference, and those differences, artificial and tenuous, not only distinguish the nation from other nations but also divided the citizens within its own boundaries. ${ }^{43}$

That black Britons' "membership in the nation was tentative and unstable" reveals the 'fictive', contingent and insecure nature of national identity itself. ${ }^{44}$ This is reflected in the image of the black servant where the black subject gains entry to the heart of the white home but only under terms which bind him to difference, marginalisation and subservience. He is limited to being, to use the words of Ignatius Sancho, "only a lodger, and hardly that." 45

Through their reappropriation of this rhetorical device Shonibare and Himid alert us to continuing restrictions on black Britons' practices of nationhood. They demonstrate the contemporary efficacy of the stereotyped image of the black domestic servant while proving that it is not beyond salvage. Indeed, by revealing its means

41 Fort (2001), 292.

42 Wilson (2000), 171

43 Wilson (2000), 174.

44 Wilson (2000), 169

45 Sancho (1782), 92. 
of construction they offer the possibility of the figure's reuse as postcolonial hero, survivor, witness and protagonist.

\section{Works Cited}

Berg, Maxine (2005): Luxury \& Pleasure in Eigbteenth-Century Britain. Oxford: Oxford University Press.

Bhabha, Homi K. (1983): "The Other Question: The Stereotype and Colonial Discourse," in: Screen 24(6), 18-36.

Bindman, David (2001): “A Voluptuous Alliance between Africa and Europe': Hogarth's Africans," in: Fort, B./Rosenthal, A., eds.: The Other Hogarth, Aesthetics of Difference. Princeton, NJ: Princeton University Press, 260-269.

Brewer, John/Roy Porter, eds. (1993): Consumption and the World of Goods. London: Routledge.

Dabydeen, David (1992): “The Role of Black People in William Hogarth's Criticism of Eighteenth-Century English Culture and Society," in: Gundara, J.S./Duffield, I., eds.: Essays on the History of Blacks in Britain. Aldershot: Avebury, 30-57.

Dabydeen, David (1987): Hogarth's Blacks: Images of Blacks in Eighteenth Century English Art. Athens, GO: University of Georgia Press.

Fort, Bernadette (2001): "Lubaina Himid's A Fashionable Marriage: A PostColonial Hogarthian 'Dumb Show'," in: Fort, B./Rosenthal, A., eds.: The Other Hogarth, Aesthetics of Difference. Princeton, NJ: Princeton University Press, 278-293.

Gerzina, Gretchen (1995): Black London, Life Before Emancipation. New Brunswick, NJ: Rutgers University Press.

Hecht, J. Jean (1954): Continental and Colonial Servants in Eighteenth Century England (=Smith College Studies in History XL). Northampton, MA: Department of History of Smith College.

Himid, Lubaina (2001): “A Fashionable Marriage," in: Fort, B./Rosenthal, A., eds.: The Other Hogarth, Aesthetics of Difference. Princeton, NJ: Princeton University Press, 270-277.

Kaplan, Paul (1982): “Titian's 'Laura Dianti' and the Origins of the Motif of the Black Page in Portraiture," in Antichita Viva 1(1), 11-18; 4(2), 1018.

Molineux, Catherine (2005): "Hogarth's Fashionable Slaves: Moral Corruption in Eighteenth-Century London," in: ELH 72, 495-520.

Myers, Norma (1996): Reconstructing the Black Past; Blacks in Britain 1780-1830. London: Frank Cass.

Tharp, Lars (1997): Hogarth's China, Hogarth's Paintings and Eigbteenth-Century Ceramics. London: Merrell Holberton.

Fowkes Tobin, Beth (1999): Picturing Imperial Power, Colonial Subjects in Eighteenth-Century British Painting. Durham, NC: Duke University Press. 
Richards, Sarah (1999): Eighteenth-Century Ceramics: Products for a Civilised Society. Manchester: Manchester University Press.

Sancho, Ignatius (1782): Letters of the Late Ignatius Sancho: An African, to which are Prefixed, Memoirs of his Life. London: John Nichols.

Shonibare, Yinka/Rego, Paula/Chapman, Jake (2007): “The Artist's Progress: Hogarth's Legacy in the 21st Century," The Guardian, 13 Jan. 2007, online at: http://arts.guardian.co.uk/features/story/0,1989246,00.html (accessed on 11.2.2007).

Walvin, James (2001): Black Ivory: Slavery in the British Empire. Oxford: Blackwell.

Waterfield, Giles/French, Anne/ Craske, Matthew (2003): 400 Years of Servants' Portraits. London: National Portrait Gallery.

Wilson, Kathryn (2000): "Citizenship, Empire and Modernity in the English Provinces," in: Hall, Catherine, ed.: Cultures of Empire: A Reader. Manchester: Manchester University Press, 157-186. 
Re-Constructing Toussaint in the Romantic Era: History,
Agency and the Haitian Revolution (1791-1804)

Franca Dellarosa

\section{Introduction}

As modern historians have recognized, the Haitian revolution was "the most violent step toward the end of the plantation complex,"1 an act of self-liberation originating from the "revolutionary Atlantic"2 which brought about the overthrow of slavery in the richest and most productive European colony in the Caribbean, as well as a determining factor in the balance of the relations in world politics at the turn of the century.

In the British metropolitan context, both the political debate and public opinion responded to the potential spreading of slave revolt in the area with deep disquiet. Evidence can be found in the widespread circulation in England of printed matter such as the translation of speeches with ghastly reporting of the 'Insurrection of the Negroes' before the National Assembly in France, ${ }^{3}$ and accounts

1 Curtin (1998), 158.

2 See Linebaugh/Rediker (2000). A detailed reconstruction of the St Domingue revolt and its complex rapport with the European chequerboard and the ongoing French Revolution is given in Blackburn (1998), 161-264. See also Davis (1999), 137-163. Recent historical scholarship on the Haitian revolution includes Geggus ed. (2001); Geggus (2002), and Dubois (2006).

3 A Particular Account of the Commencement and Progress of the Insurrection of the Negroes in St. Domingo, which Began in August, 1791: Being a Translation of the Speech Made to the National Assembly, the $3^{\text {rd }}$ of November, 1791, by the Deputies from the General Assembly of the French Part of St. Domingo, London: J. Sewell, 1792. The document went through four editions in English. See Geggus (1982), 125-126, which gives a documented illustration of the debate in England. 
such as Bryan Edwards's, which called attention to "the danger to which every island in the West Indies would be exposed from such an example, if the triumph of savage anarchy over all order and government should be complete."4 Felix quem faciunt aliena pericula cautum, as recited the epigraph to the English edition of the French documents, with the translator's note recommending their "attentive perusal to every thinking, dispassionate, Englishman," and further commenting, with an all too transparent metaphor: "When our neighbour's house is on fire, it can never be amiss to play a little upon our own." 5 On the other hand, anti-French and anti-Bonaparte feelings fostered some support for the rebel blacks, while their leader's tragic plight was later to raise respectful consideration: "if fortune were always constant to merit," as the Annual Register for 1802 stated, "in Toussaint L'Ouverture, not only the poet, but the faithful historian, would have seen 'hands which the rod of empire might have swayed."'6 While the quote from Thomas Gray's Elegy on a Country Churchyard appropriately seems to point to the fate of neglect and historical erasure that was awaiting the revolution of Haiti and his leader as brought about by a prevailingly Eurocentric historiography, ${ }^{7}$ the double level of historical/poetic meta-narrative, evoked in the Annual Register's comment as becoming the public consumption of the parable of Toussaint L'Ouverture, ironically points to an acte manqué, since the English Romantics have too been recorded by modern commentators as having displayed a relative lack of "attention and sympathy," and as mostly failing to respond to the Haitian struggle for liberty. ${ }^{8}$ Still, a process of re-elaboration of the St Domingo revolt and of the figure of its charismatic leader, which was both political and aesthetic, was indeed carried out in the

4 Edwards (1797), iii-iv. Sympathies for the abolitionist cause and its political itinerary in Britain were obviously paced down by the growing conservatism, both within and outside Parliament, that developed as a reaction to the French Revolution and the subsequent slave insurrection in St Domingo. See Oldfield (1998), 60-61.

5 A Particular Account (see footnote 3), iii-iv.

6 (1803), 211 (my emphasis).

7 The passage, taken from stanza 12 of Gray's Elegy, recites, "Perhaps in this neglected spot is laid / Some heart once pregnant with celestial fire; / Hands, that the rod of empire might have swayed / Or waked to ecstasy the divine lyre." As to the "scholarly blindness" regarding the Haitian revolution, see Buck-Morss (2000), passim (834n); Walvin in James (2001), viii-ix; Aravamudan (1999), 292.

8 According to David Geggus, "Wordsworth's sonnet stands alone." Geggus (1982), 140$146(145)$. 
poetic output of those years, embedded within the network of public discourses, in fact actively participating in and constructing them, and responding to ideological conflicts that re-enacted those at work in the public debate. While maintaining that the Haitian Revolution "inspired a powerful alternative to the passive or suicidal 'dying slave' convention of abolitionist verse," Alan Richardson has also argued for the ambivalence of the British response, whereby "agency, might and a just cause [as attributed] to the slaves who plot revenge and successfully rise against their French masters" are shown to coexist with "fears of African barbarity unleashed in WestIndian slave rebellions." 9

Whereas young Robert Southey at his most radical claimed for "the just and general rebellion of the Negroes" and for the arising of a vengeful (however abstract) 'Genius of Africa,'10 the figure of Toussaint L'Ouverture appears as the explicit protagonist of two poems, a renowned sonnet by William Wordsworth, and a far less known poetic composition in a ballad-like form by Edward Rushton. Written in the span of a few months, presumably immediately before and shortly after Toussaint's capture by the French in June 1802 and his transportation to France, where he died in April 1803, the two poems exemplify fundamentally distant ideological attitudes to the historical event and the historical character as such, which also influence the terms of their transmutation into poetic discourse. I shall obliquely rely on the critical paradigm of tropicalization, as proposed by Srinivas Aravamudan, ${ }^{11}$ to argue for the enactment of agency in Rushton's metropolitan poem as an exemplification of this poet's radi-

9 Richardson (1999), 239. The anonymous Ode to "The Insurrection of the Slaves at St. Domingo," written in 1792 and published in 1797 in The Courier, is offered as an exemplification of such ambivalence.

10 Robert Southey (1797), 32, 39-42.

11 See Aravamudan (1999), 1-25: "I would like to propose the term tropicopolitan as a name for the colonized subject who exists both as fictive construct of colonial tropology and actual resident of tropical space, object of representation and agent of resistance. [...] Despite the fact that most linguistic change could be attributed to contingent and unmotivated shift sign changes certainly can also reflect individual or collective intentions [...] I characterize motivated instances of such change within colonialist contexts as tropicalizations. By motivated, I would like to suggest a gamut of causal factors, including discursive, historical, and psychoanalytical determinations in addition to the conscious intentions of agents. Tropicalization means a tropological revision of discourses of colonial domination (something that can happen immediately and directly as well as retroactively and indirectly.) Such a revision is ultimately a contestation of European rule by tropicopolitans, inhabitants of the torrid zones that were the objects of Europe's colonial ambition." (4-6). 
cal critique, which performs a global call against all forms of imperialism and oppression.

\section{Re-Constructing Toussaint}

The modern reader is required to trace and map out a complex, transnational geopolitics of disorder and resistance, the outline of the many-headed hydra, with Linebaugh and Rediker, ${ }^{12}$ as emerging from the poetic corpus of Edward Rushton, a radical poet and intellectual from Liverpool - a city which, in Karl Marx's words, had "waxed fat" on the transatlantic slave trade. ${ }^{13}$ Edward Rushton's biographical experience, his first-hand knowledge and early rejection of the brutality of the slave trade as young officer in a slave ship, where he lost his sight as a consequence of his attempt to give aid to the human cargo, victims of epidemic ophtalmia - and later, his activity as co-editor of a weekly paper in Liverpool, which he was forced to quit because of his stand against seamen impressment, ${ }^{14}$ testify to his life-long commitment against all forms of oppression. His comparatively slender output of writings unmasks what Immanuel Wallerstein has described as the disquieting "symbiotic relationship of presumed opposites,"15 i.e. eighteenth-century universalism and the contiguous, increasing radicalisation of human difference. It also offers a paradigm of radicalism that encapsulates the truly global import of a variety of enflamed political issues at the turn of the nineteenth century, touching, as it does, literally all corners of the world under the banner of liberty. An alternative narrative of world politics takes shape in Rushton's macro-text, which privileges voices otherwise left silent, enacting the process that comes to pass, as historian Susan Buck-Morss has suggested, "every time that the consciousness of individuals surpasse[s] the confines of present constellations of power."16

The elaboration of this somewhat visionary poetic/political project entails a crucial entanglement with those "categories of dif-

12 Linebaugh/Rediker (2000), 2-4.

13 Capital: A Critique of Political Economy (1867), in: Engerman et al. (2001), 392.

14 See Shepherd (1824).

15 Wallerstein (2002), 29-31 (29).

16 Buck-Morss (2000), 865. 
ference," 17 whose incipient modern articulation is coterminous with the Age of Revolution, which is Edward Rushton's historical context-in-the-making. Class, nation, race - ambiguous identities, according to Etienne Balibar's and Immanuel Wallerstein's felicitous formulation - constitute the conceptual ambits and historical actualities which define the ideological arena where Rushton's writing stands in permanent confrontation. 'Local' and 'global' are space dimensions which intertwine in Rushton's knowing reconstruction of a comprehensive world map of violence and displacement. From Bartholomew Tilski, the Polish patriot "publicly executed" "in the vigour of his days," 18 to the enslaved warrior people of Africa, the Coromantees, whose potential for revolt is prophetically conjured up, to Toussaint L'Ouverture, the Black Jacobin imagined as addressing "His Troops," Rushton enlists a range of radical experiences in his own personal geography of oppression, which does not fail to include victims of power closer to home, such as the Irish people and the lower classes forced to enrol in the military by the brutality of the press-gang.

Collective memory is implicitly identified as a powerful instrument for the re-construction of (national) identity out of a supposedly shared body of experience and suffering in an imaginative process which implies, with Balibar, "the projection of individual existence into the weft of a collective narrative."19 Rushton's evident sympathies with all the insurrectional movements traversing Europe and the Americas between the two centuries and threatening established world order entail unbending denunciation of all forms of imperialism - whether it be British, or French Napoleonic, or Russian, as is testified by his insistence on the role of collective memory of patriotic action and the handing down of its narrative "to myriads yet unborn," 20 which shapes his poem dedicated "To the Memory of Bartholomew Tilski, a native of the North of Poland."

Shared suffering as a determining factor in the construction of self-identity qua collective is shown as a peculiarly subversive driving force in the body of Rushton's poems concerning the foulest stain ${ }^{21}$ of

17 See Nussbaum (1990), Wheeler (2000), Wilson (2003).

18 Rushton (1824), 78.

19 Balibar (2002), 93-95 (93).

20 Rushton (1824), 78.

21 Rushton (1787), I, 1. 
slavery. In these poetic texts, by a rhetorical turn which readers of Rushton soon recognise as peculiarly his own, the voiceless par excellence - the enslaved Africans - are given full voice, often to articulate resistance. 22 "Toussaint to His Troops" was included in the 1806 volume of Poems, which was his only published collection during his lifetime. The leader of "the only successful slave revolt in history," as C. L. R. James reminds us, is the poem's protagonist and speaking voice, acting out the revolt which generated "one of the great epics of revolutionary struggle and achievement," with "the transformation of slaves, trembling in hundreds before a single white man, into a people able to organize themselves and defeat the most powerful European nations of their day." 23 "Toussaint to His Troops" responds to the epic investment called for in the 1938 Preface to The Black Jacobins, and articulates it in terms which at once embed the poem within and distance it from the mainstream poetic discourse of abolitionism:

When the world's eternal Sire

Placed on high yon glorious fire,

Were the splendid beams design'd

For a part of human kind?

No! ye sable warriors, no!

All that live partake the glow:

Thus, on man, the impartial God

Light, and winds, and rains bestow'd;

And widely thus were pour'd his dearest rights,

And he who slights the gift - the Almighty donor slights. ${ }^{24}$

Stanza 2 exemplifies this tension, as it clearly echoes the opening lines of Hannah More's 1788 "Slavery: A Poem", almost taking up the very wording of the Bristol poet:

If Heaven has into being deign'd to call

Thy Light, O LIBERTY! to shine on all;

Bright intellectual Sun! why does thy ray

To earth distribute only partial day?

22 I have argued elsewhere the ideological relevance of Rushton's use of the semi-dramatic eclogue form in his four-poem sequence of West-Indian Eclogues. See Dellarosa (2005), 2529 .

23 James (2001), xviii.

24 Rushton (1806), 19. The poem is also included in the 1824 posthumous edition, with slight variations, mostly regarding punctuation (94-97). 
$[\ldots]$

While the chill North with thy bright ray is blest,

Why should fell darkness half the South invest?

Was it decreed, fair Freedom! at thy birth,

That thou shou'd'st ne'er irradiate all earth?

While Britain basks in thy full blaze of light,

Why lies sad Afric quench'd in total night?25

Both texts build on the metaphorical relation of the Sun for Liberty, which is rendered explicit in the earlier text, only to be subsumed by inference in Rushton's. It soon appears clear, however, that the terms of More's iterated and unanswered questions are substantially reversed. In More's lines, the mute addressee of the questions, i.e. the abstract figuration of the "bright intellectual Sun," Liberty itself, is inert, and the issue on the part of the poetic voice regarding the right of all to "bask" in the sun of freedom is offered no solution. In the Rushton text, the poetic stance establishes a rhetorical frame which is clearly meant to convey the sense of black agency, as transmitted by the performative speech act involving the General as addresser and the addressees of his speech, "his troops"- "ye sable warriors" - with Toussaint's affirmative action, as it were, that turns the tentative questioning of the poetic voice in More's text into statement.

Internal evidence suggests that the poem may have been written sometime in early 1802, in the phase that immediately preceded Toussaint's capture by General Leclerc, the commander of "the vaunted legions $[\ldots]$ / by freedom nerved no more" - the Napoleonic expedition that was sent in December 1801 to re-establish French control over Haiti, ${ }^{26}$ and which is exposed in the poem as carrying out the blatant betrayal of the revolutionary tenets:

Now with canvass white as foam,

See the vaunted legions come,

Nerved by freedom, once they rose

And o'erwhelm'd a world of foes:

Now by freedom nerved no more,

Lo! The miscreants seek our shore;

Yes, the French, who waste their breath,

Chaunting liberty or death, 
Sweep the blue waves at usurpation's word,

And bring, oh, fiends accursed! Oppression or the sword. ${ }^{27}$

"Liberty or death," as has often been noted, were catchwords widely resonating in the revolutionary context, and were also the motto that the fighting rebels of Haiti inscribed in the blue and red flag, from which the white band that made up the French colours had been removed. The new flag was hoisted on 18 May 1803 by order of General Dessalines as a token of the dissevering destinies of Haiti and France. ${ }^{28}$

In the meanwhile, the leader's individual parable was accomplished. Toussaint L'Ouverture was arrested in June 1802 and transported to the Fort-de-Joux in the Jura mountains, where he died after a ten-month harsh detention on 7 April 1803.29 The circumstances of his death, according to Srinivas Aravamudan, contributed to the process of "heroization" that presided over "Romantic assessments" of Toussaint, entailing a figurative movement of "Romantic metaphorization," 30 as exemplified in William Wordsworth's sonnet "To Toussaint L'Ouverture." An imprisoned, shattered Toussaint is the addressee of the poem, first published on 2 February 1803 in The Morning Post.

TOUSSAINT, the most unhappy man of men!

Whether the whistling Rustic tend his plough

Within thy hearing, or thy head be now

Pillowed in some deep dungeon's earless den;

O miserable Chieftain! where and when

Wilt thou find patience? Yet die not; do thou

Wear rather in thy bonds a cheerful brow:

Though fallen thyself, never to rise again,

Live, and take comfort. Thou hast left behind

Powers that will work for thee; air, earth, and skies;

There's not a breathing of the common wind

That will forget thee; thou hast great allies;

Thy friends are exultations, agonies,

And love, and man's unconquerable mind. ${ }^{31}$

27 Ruston (1806), 19-20

28 Ruston (1806), 294-295; Buck-Morss (2000), 835-836; Blackburn (1988), 230.

29 James (2001), 270-272, 294

30 Aravamudan (1999), 310-311.

31 Wordsworth (1969), 242-3. See Richardson (1999), 268-269, and Thomas (2000), 109. 
Dejection pervades the figuration of the "unhappy [...] miserable [...] fallen-never-to-rise-again" Chieftain, whose attributes as military leader, as Helen Thomas has argued, are situated "within a schema that avoids any discussion of race," while implying the "prioritization of the symbolic emblem of Romanticism - the power of 'man's unconquerable mind,' the imagination.."32 In other words, the neutralisation of the historical topicality of the leader of the revolt of San Domingo, as entailed in Wordsworth's homage, would seem to be the price to be paid for his elevation as an abstract exemplification of man's spiritual potentialities, as unfolding in a symbiotic relationship with nature. As Aravamudan suggests, however, traces of the hero's historical predicament are still conveyed in the "agonies" which conjure up the suffering, "mute body" of the hero, speaking via the poet: "Toussaint's bonds, like Prometheus's, are a powerful metaphor of Romantic empowerment. [...] Toussaint's imprisonment constitutes, in this poem, English Romantic freedom." 33

\section{Scenes of Reading 1}

In his compelling reconstruction of the "retroactive process" of metaliteracy that led to the formation of Toussaint L'Ouverture's "mythistorical" substance, in terms of both colonial ('tropicopolitan') re-appropriation and metropolitan reworking, Srinivas Aravamudan interrogates some crucial "scenes of reading," 34 and extensively discusses the centrality of Abbé Guillaume-Thomas Raynal's monumental Histoire philosophique et politique du commerce et des établissements des Européens dans les deux Indes. First published in 1770 and widely revised for the third successful edition by Denis Diderot in 1780 , in the decades following its publication Raynal's Histoire constituted a major, polymorphous and pluridiscursive source of historical and anthropological information regarding the Europeanised space of worldwide commerce. Raynal's work was extremely popular and widely read throughout Europe and in Britain, where a translation of

32 Thomas (2000), 110. See also Persyn (2002).

33 Aravamudan (1999), 312.

34 In Aravamudan's view, "scenes of reading", as a response to colonialist arguments falsifying the relationship between literacy and civilisation, "generate a kind of metaliteracy, enabling the reconceptualization and tropicalization of that purported relationship." Aravamudan (1999), 289. 
the first edition appeared in 1776, running through no less than eighteen editions, and where the text, with its "radical emancipationist underside to a mercantilist encyclopedia," played an important role in the shaping of antislavery discourse. ${ }^{35}$

The emergence of Toussaint L'Ouverture as leader of the Haitian revolution was soon to be associated with the 'black Spartacus' passage in the Histoire des deux Indes, where, in the form of an apostrophe, a black leadership to come is prophetically foreshadowed as destined to bring about "vengeance and carnage" on behalf of the oppressed slaves:

Ah well, if it is only self-interest that motivates your soul, countries of Europe, listen to me again. Your slaves don't need either your generosity or your advice to break the sacrilegious yoke that oppresses them. Nature speaks more powerfully than philosophy or self-interest. Already, two colonies of black fugitives have established themselves, safe from your assaults, through treaties and force. These streaks of lightning announce the oncoming thunderbolts, and the blacks only need a leader courageous enough to lead them towards vengeance and carnage. Where is this great man that Nature owes to her vexed, oppressed, and tormented children? Where is he? He will appear, never fear, he will show himself and raise the sacred flag of liberty. This venerable signal will allow the companions of his misfortune to rally around him. More violent than waterfalls, they will leave indelible traces of their justifiable resentment everywhere. Spaniards, Portuguese, English, French, and Hollanders, indeed all their tyrannical masters will fall prey to fire and brimstone. The American fields will get ecstatically drunk with the bloodshed they have awaited for ages, and the bones of so many unfortunates, piled up for centuries, will quiver with joy. The Old World will applaud the New World. Everywhere will be exalted the name of the hero who would have re-established the rights of the human race; memorials will be erected to celebrate his glory everywhere! Then the Black Slave Code will disappear, and the "White Slave Code' will indeed be terrible if the victor merely follows the law of revenge! 36

35 Aravamudan (1999), 288-300 (291), where the critic also examines the Histoire's radical criticism of the ancien régime and the complex mechanisms of its later Jacobin appropriation, connected with the text's reception history and the collective reading practices at work with metropolitan audiences.

36 Histoire des deux Indes, 6: 206-208, tr. by Aravamudan (1999), 301-302. 
Despite the paucity of historical evidence as to Toussaint's having actually read and been inspired by Raynal's text, the identification brought about by the short-circuiting of historical occurrence with the "desire for narratives of agency that foreground metaliteracy" fostered the appropriation in the island of the Histoire as a proactive prophecy of revolution, and of its author as a revolutionary hero, thus generating a narrative of national origin, endowed with retroactive "revolutionary consciousness." ${ }^{37}$ Such a manoeuvre of tropicalization of the Enlightenment, to use Aravamudan's critical metalanguage, is substantiated in the eccentric reading of the metropolitan text as addressing, however indirectly and incidentally, the colonized subject. "No wonder," as C. L. R. James observes in his own narrative/historical reconstruction, "[Toussaint] came in the end to believe himself as the black Spartacus, foretold by Raynal as predestined to achieve the emancipation of the blacks." 38

\section{Scenes of Reading 2}

In the memoir attached to the 1824 posthumous edition of Edward Rushton's Poems, the impoverished to the edge of destitution, blind ex-sailor Edward Rushton is depicted by his biographer Reverend William Shepherd around the year 1780 as engaged in a long-lasting and imaginatively most demanding activity of metaliteracy:

He was $[\ldots]$ compelled to provide himself with food by the allowance allotted to him by his father, which was, moreover, diminished by three-pence per week, which he gave to a boy as wages for reading to him an hour or two every evening. The aid of this humble servant, and of the few friends who occasionally supplied his office, enabled Mr. Rushton to beguile the weary length of seven years, during which he was thus condemned to penury and destitution. But to indicate that he thus beguiled the weariness of his darksome days, is not doing justice to his merits. He converted the apparent misery of his circumstances to considerable mental profit. The course of reading which he adopted was in the highest degree judicious. He availed himself of this pe-

37 Aravamudan (1999), 302-303; Blackburn (1988), 219, 243: "In the Governor's Palace [at Port-au-Prince, which served as Toussaint's official residence and headquarters] and other public buildings were to be found busts and portraits of Raynal, who, rather than Rousseau or Condorcet, was adopted as the prophet of the new order."

38 James (2001), 203. 
riod of leisure to become well acquainted with the works of Addison, Steele, Johnson, and the other celebrated English essayists. His love of his late profession led him to listen with eagerness and intelligence to the reading of voyages and travels; and he familiarized himself with history, especially with the history of his country. From his father he inherited a fondness for the Muse, which he gratified by the perusal of the works of our best poets, the striking passages of which he stored up in a most retentive memory. Dramatic compositions, too, engaged his lively attention. In these he took an extensive range. The plays of Shakespeare were 'familiar to his lips as household words.' But, in consequence, perhaps, of his labouring under the same calamity as Milton, that author was his favourite; and he was assiduous in making himself master, not only of his immortal poems, but also of prose works, which it is the fashion of the present day too much to neglect. In the meantime he spent his numerous solitary hours in meditating on what had been read to him, and in speculations in which a philosophic mind is fond of indulging. ${ }^{39}$

As the recipient of an activity of reading vicariously fulfilled for him by somebody else, young, intellectually curious, increasingly radical Edward Rushton from Liverpool must have come across a network of texts that had some impact in terms of intellectual formation and potential imaginative reworking, as the "numerous solitary hours" spent "in meditating" and "speculations" allow us to infer. Only a little imaginative step is needed, of a similar sort as the one claimed by Srinivas Aravamudan in his reconstruction of Toussaint's virtual reading of Raynal, ${ }^{40}$ to envisage the apostrophe of the black Spartacus passage, as read aloud - possibly, recited, to an allabsorbing listening single auditor. While there is no direct reference to Raynal's work in Rushton's macrotext, the Histoire is extensively quoted in the massive apparatus of notes accompanying the series of four eclogues in Poems Chiefly on Slavery and Oppression (1788) by Hugh Mulligan, a radical Irishman living in Liverpool and an acquaintance of Rushton's. ${ }^{41}$ That Rushton knew Raynal is therefore, in any case,

39 Shepherd (1824), xvi-xvii. There is an obvious mistake in pagination here, as the sequence of pages is actually xvi-xiii, with the pages xiii-xvi consequently counted twice.

40 "The impact that Histoire de deux Indes had on the French colonies can be reconstructed, if somewhat imaginatively, by a literary-critical urge to rush in where historians fear to tread." Aravamudan (1999), 299.

41 An elegy "On the Death of Hugh Mulligan" is included in Rushton (1806), 28-30. An apocalyptic slave revolt was dramatically envisaged in Mulligan's "American Eclogue," 
virtually certain. "Toussaint to His Troops" provides a poetic metareading, coming from a radical metropolitan abolitionist context, which mirrors and replicates the tropicopolitan process of appropriation of the Raynal text as carried out in the Atlantic context. Mimicry is the privileged instrument in the process, whereby the poetic stance is made to coincide with the represented subject and the metropoli$\tan$ writer "as ventriloquist embraces the impropriety inherent in speaking mimetically for someone else." ${ }^{42}$

Men, whose famish'd sides have felt

Strokes by dastard drivers dealt;

Men, whose sorrowing souls have borne

Wrong and outrage, toil and scorn;

Men, whose wives the pallid brood

Have, by torturing arts, subdu'd;

Friends of Toussaint! warriors brave!

Call to mind the mangled slave!

$[\ldots]$

Towering spirits! ye who broke

Slavery's agonizing yoke;

Ye, who like the whirlwind rush'd,

And your foes to atoms crush'd;

Ye, who from Domingo's strand,

Swept the daring British band;

Ye, oh warriors! Ye, who know

Freedom's bliss and slavery's woe,

Say! Shall we bow to Bonaparte's train,

Or with unshaken nerves yon murderous whites disdain.

From those eyes that round me roll,

Wildly flash the indignant soul;

On those rugged brows I see,

Stern unyielding liberty.

Yes! your daring aspects show,

France shall soon repent the blow;

Soon shall famish'd sharks be fed;

years before the Haitian revolution was sparked. See Mulligan (1788), 6-7; see also Dellarosa (2005), 20-21.

42 Aravamudan (1999), 314, referring to Diderot. Mimicry as "one of the most elusive and effective strategies of colonial power and knowledge" is discussed in Bhabha (2004), 121 131 (122). However, Aravamudan points out how mimicry and parody can be turned to articulate resistance and "help us describe the subaltern's answer to the dominant discourse.” Aravamudan (1999), 300. 
Vultures soon shall tear the dead;

Oh glorious hour! now, now, yon fiends defy,

Assert great nature's cause, live free, or bravely die. ${ }^{43}$

Traces of the black Spartacus rhetoric are detectable in the text, with the "sacrilegious yoke" of slavery in the Raynal text that is envisaged as now "agonizing." Analogously, the "whirlwind" of slave revolution sweeping away enemies imaginatively materializes "the oncoming thunderbolts" that the "streaks of lightning" of the earlier insurrections had announced. The transnational nature of the struggle in the black Spartacus passage, involving the revolting enslaved people in a fight against all European slave-holding powers - "Spaniards, Portuguese, English, French, and Hollanders" - is here strategically epitomised in the annihilation of the "daring British band," which historicises the call to revolt in the Haitian context. ${ }^{44}$ The final stanza establishes a rhetorical crescendo of violence as conveyed by and somewhat displaced in the animal imagery, with a natural world witnessing human violence that is peopled with "sharks" and "vultures," fed with its (culpable) victims. The black leader's appeal to his "warriors" for the assertion of "great nature's cause" - man's right to freedom - closes the poem with the vindication of the Liberty-or-Death revolutionary motto, thus imaginatively answering the question posed in the Raynal text: "Where is this great man that $\mathrm{Na}$ ture owes to her vexed, oppressed, and tormented children?" A General, but also member of the motley cren ${ }^{45}$ that peoples Rushton's underworld of marginalised and oppressed communities and nations, Toussaint, as speaking to his troops, is re-constructed for the metropolitan context via the textual common ground - the black Spartacus that presides over the mythistorical self-construction of the tropicopolitan subject. objective "to regain the islands seized by the French [St. Vincent and Grenada] and to complete the occupation of St. Domingue." Blackburn (1988), 230-240 (231). Between 1796 and 1798 they faced heavy losses, due both to black resistance and disease, and evacuated the island at the end of 1798. See James (2001), 163-175.

45 Linebaugh/Rediker (2000), 211-213. 


\section{Conclusion}

An intense perception of historical topicality, along with an underlying awareness of the racial issue and a painful sensitiveness to the traumatic experience of enslavement are at the heart of Rushton's construction, marking its distance with respect to Wordsworth's. This distance may well be epitomized in the almost chiastic relation between the two titles. This, in turn, points to the signifying dynamics entailed in the relationship between addresser and addressee, whether it be subsumed in the poetic stance, as happens with Wordsworth, where Toussaint is the silent, inert recipient of the poetic discourse, or internal to the mimetic attempt at poetic reconstruction, as in the Rushton text, which turns insistently on the power of memory - "Call to mind the mangled slave!"46 - as a means to re-appropriate identity and oppose resistance to the erasure of history.

\section{Works Cited}

(1803): The Annual Register, or a View of the History, Politics, and Literature, for the Year 1802. London: Wilks.

Aravamudan, Srinivas (1999): Tropicopolitans: Colonialism and Agency, 16881804. Durham, NC: Duke University Press.

Balibar, Etienne/Wallerstein, Immanuel (2002): Race, Nation, Class: Ambiguous Identities. London: Verso.

Balibar, Etienne (2002): "The Nation Form: History and Ideology," in: Balibar, Etienne/Wallerstein, Immanuel: Race, Nation, Class: Ambiguous Identities. London: Verso, 86-106.

Bhabha, Homi (2004): "Of Mimicry and Man: The Ambivalence of Colonial Discourse," in: Bhabha, Homi: The Location of Culture. London: Routledge, 121-131.

Blackburn, Robin (1988): The Overthrow of Colonial Slavery 1776-1848. London: Verso.

Buck-Morss, Susan (2000): "Hegel and Haiti," in: Critical Inquiry 26, 821-865.

Curtin, Philip D. (1998): The Rise and Fall of the Plantation Complex: Essays in Atlantic History. $2^{\text {nd }}$ ed. Cambridge: Cambridge University Press.

46 Interestingly, in the 1824 posthumous edition, the performative exclamation mark of the earlier edition is replaced by a more tentative question mark: "Call to mind the mangled slaves?" See Rushton (1824), 96. 
Dellarosa, Franca (2005): "Questioning the 'Enterprising Spirit of the People': Abolitionist Poetry in Liverpool, 1784-1788," in: La Questione Romantica 18/19, 17-31.

Dubois, Laurent (2006): Avengers of the New World: The Story of the Haitian Revolution. Cambridge, MA: The Belknap Press of Harvard University Press.

Engerman, Stanley/Drescher, Seymour/Paquette, Robert, eds. (2001): Slavery. Oxford: Oxford University Press.

Geggus, David (1982): "British Opinion and the Emergence of Haiti," in: Walvin, James, ed.: Slavery and British Society 1776-1846. Baton Rouge: Louisiana State University Press, 123-149.

Geggus, David (1985): "Haiti and the Abolitionists: Opinion, Propaganda and International Politics in Britain and France," in: Richardson, David, ed.: Abolition and Its Aftermath: The Historical Context, 1790-1816. London: Frank Cass, 113-140.

Geggus, David, ed. (2001): The Impact of the Haitian Revolution in the Atlantic World. Columbia, SC: University of South Carolina Press.

Geggus, David (2002): Haiti Revolutionary Studies. Bloomington/IN.: Indiana University Press.

James, C.L.R. (2001): The Black Jacobins: Toussaint L'Ouverture and the San Domingo Revolution (1938), with an Introduction and Notes by James Walvin. London: Penguin Books.

Linebaugh, Peter/Rediker, Marcus (2000): The Many-Headed Hydra: The Hidden History of the Revolutionary Atlantic. London: Verso.

More, Hannah (1999): Slavery: A Poem (1788) in: Richardson, Alan, ed.: Slavery, Abolition and Emancipation: Writings in the British Romantic Period, Vol. 4: Verse. London: Pickering \& Chatto, 103-125.

Mulligan, Hugh (1788): Poems Chiefly on Slavery and Oppression. London: Lowndes.

Nussbaum, Felicity (1990): “The Politics of Difference," in: EighteenthCentury Studies 23 (4), 375-386.

Oldfield, J. R. (1998): Popular Politics and British Anti-Slavery: The Mobilisation of Public Opinion Against the Slave Trade 1787-1807. London: Cass.

Oldfield, J. R. (1792): A Particular Account of the Commencement and Progress of the Insurrection of the Negroes in St. Domingo, which Began in August, 1791: Being a Translation of the Speech Made to the National Assembly, the 3rd of November, 1791, by the Deputies from the General Assembly of the French Part of St. Domingo, London: J. Sewell.

Persyn, Mary (2002): “The Sublime Turn Away from Empire: Wordsworth's Encounter with Colonial Slavery, 1802," in: Romanticism on the Net 26, online at http://www.erudit.org/revue/ron/2002/v/n26/005700ar.html (accessed on 3.3.2008)

Richardson, Alan, ed. (1999): Slavery, Abolition and Emancipation: Writings in the British Romantic Period, Vol. 4: Verse. London: Pickering \& Chatto. 
Rushton, Edward (1787): West-Indian Eclogues. London: Lowndes.

Rushton, Edward (1806): Poems. London: T. Ostell.

Rushton, Edward (1824): Poems and Other Writings, to Which is Added, a Sketch of the Life of the Author by the Rev. William Shepherd. London: Effingham Wilson.

Shepherd, William (1824): "A Sketch of the Life of the Author," in: Poems and Other Writings by the Late Edward Rushton. London: Effingham Wilson, Royal Exchange, ix-xxviii.

Southey, Robert (1797): Poems, Second Edition. Bristol: N. Biggs for J. Cottle.

Thomas, Helen (2000): Romanticism and Slave Narratives: Transatlantic Testimonies. Cambridge: Cambridge University Press.

Wallerstein, Immanuel (2002): "The Ideological Tensions of Capitalism: Universalism versus Racism and Sexism," in: Balibar, Etienne/Wallerstein, Immanuel: Race, Nation, Class: Ambiguous Identities. London: Verso, 29-36.

Wheeler, Roxann (2000): The Complexion of Race: Categories of Difference in Eighteenth-Century British Culture. Philadelphia: University of Pennsylvania Press.

Wilson, Kathleen (2003): The Island Race: Englishness, Empire and Gender in the Eighteenth Century. London: Routledge.

Wordsworth, William (1969): "Toussaint to His Troops" (1803), in: de Selincourt, Ernest, ed.: Wordsworth, William: Poetical Works. Oxford: Oxford University Press, 242-243. 



\section{Resisting "Humanitarian Romanticism"1? Thomas Pringle's "Pangola: An African Tale"}

\section{Adrian Knapp}

In South Africa his death will be deeply mourned, not only by the Missionaries of all denominations, to whom he was endeared by the lively interest which be took in their labours, as well as the ties of personal friendship; not only by his colleagues and fellowlabourers in the cause of humanity, but by the thousands of the Caffre and Hottentot races, who looked to bim as a protector and benefactor. ${ }^{2}$

The laws were framed (it seems) for the exclusive benefit of the Colonists; for to the natives they were only made known in the spirit of vengeance. To oppose cunning to force, poisoned arrows to gunpowder, and perpetual harassings to the encroachments of the intruder, whom they could not openly resist, was all that was left to the wretched Bushmen. ${ }^{3}$

\section{Introduction}

In 1827, shortly after returning to Britain following a six-year-stay in the Cape Colony (1820-26), Thomas Pringle (1789-1834), the Scottish poet who is also regarded to be the first South African poet, ${ }^{4}$ was awarded the post of secretary of the anti-slavery movement in London. Pringle landed this position due to his first-hand experience and critical stance on the "mildness of Slavery at the Cape," which he in his acclaimed article "State of Slavery at the Cape" condemns to be "a bitter and baleful draught" despite its "sweetening ingredient[s]"; a "moral leprosy, which taints alike the master and the bondman." "His African Sketches, 6 however, in which, according to Ritchie, "every line has its definite object - every picture its moral

1 Memmi, (2003), 65.

2 Conder ([1835] 1966), xl. (my emphasis)

3 Pringle (1989a), 162. (my emphasis)

4 See Calder (1982), 1-13; Chapman (2003), 94-99; Pereira (1992), 1-18.

5 Pringle's article was published in London's New Monthly Magarine and Literary Journal on 17 October 1826 and is included in the appendix of Pereira/Chapman (1989), 140-8, 140, 168.

6 Pringle's Poems Illustrative of South Africa and his Narrative of a Residence in South Africa were published in 1834 as Part I and Part II in African Sketches. 
purpose," 7 is nevertheless rather ambiguous in its attack of colonial slavery. In line with Memmi's critique of 'humanitarian romanticism', this paper will question whether Pringle as a benevolent 'coloniser who refuses' can be considered a "protector and benefactor" of the oppressed in a country in which the laws are framed for the "exclusive benefit of the Colonists". This will be attempted by reading Pringle's short story "Pangola: An African Tale" against his experiences related in Narrative of a Residence in South Africa.

\section{Justifying Humanitarian Intervention}

Pringle is often remembered for his tireless struggle for a free South African press. As The Times put it on 3 December 1824, "Mr. Pringle (the Scotch bard), the late librarian and Editor of the suppressed South African Journal, is coming home to support Mr. Greig in his complaints to the English Ministers, against the administration of Lord Charles Somerset." 8 Despite the fact that Pringle only left the Cape Colony after Mr. Greig had returned from Britain in August 1825 backed by the Home Government and a licence from the Governor in Council to re-establish the South African Advertiser,' it would be wrong to underrate his qualities as a 'rebel' or even a 'revolutionary'. As Pereira and Chapman point out,

Though he was born in the year of the French Revolution, Pringle's background, early education and religious upbringing made him unsuited to the role of either a rebel or a revolutionary; on the other hand, his independence of spirit, the relative freedom he enjoyed in Edinburgh as a student and journalist, and the influence of writers such as Thomas Campbell, Moore and Byron made him an enemy of oppression in any form, and a staunch advocate of freedom and liberal values. ${ }^{10}$

So if Pringle was no rebel or revolutionary in the political sense, he was nevertheless a powerful advocate for social and moral reform. It was his persistent propagation of humanitarian intervention abroad as well as at home that made Pringle useful to the anti-slavery

7 Ritchie cit. in Pereira/Chapman (1989), xxvi. For Pereira and Chapman emphasising the moral view inherent to the Narrative, see xvii.

8 The Times (1824), 2.

9 Pringle (1966), 328, 335.

10 Pereira/Chapman (1989), xiv-xv. (my emphasis) 
movement. Vigorously emphasising the debasing effects of oppression, most gruesomely manifesting themselves in colonial slavery, Pringle succeeded in highlighting slavery's detrimental effect on the 'moral' improvement of Europe(ans) and the civilisation of Africa(ns). ${ }^{11}$ In his letter on slavery Pringle powerfully illustrates that

slave-holders, - who, though in other respects humane and good-natured, become, by long practice, altogether callous and cruel-hearted in punishing their slaves. [...] I have even known ladies, born and educated in England, charitable and benevolent in their general character, yet capable of standing over their female slaves while they were flogged, and afterwards ordering salt and pepper to be rubbed into their lacerated flesh! It is slavery, corrupting, hardening, brutalizing slavery, that produces this deplorable change in human feelings; and while it degrades to the dust the wretched victim of oppression, vitiates, by a terrible reaction, the heart and character of the oppressor. ${ }^{12}$

It is hardly surprising that the vindication of the "humanity of humankind' so fervently articulated in the fight against human enslavement can still be found in present discussions emphasising our moral responsibility to get involved in and find solutions to conflicts causing human misery and suffering. As Gary J. Bass makes clear,

All the major themes of today's heated debates about humanitarian intervention - about undermining sovereignty or supporting universal human rights, about altruistic or veiled imperialistic motivations, about the terrible dangers of taking sides in civil wars and ethic conflicts, about the role of public opinion and the press in shaping democratic foreign policy, about multilateral and unilateral uses of force, about the moral responsibility of political leaders - were voiced loud and clear throughout the nineteenth century. ${ }^{13}$

If humanitarian interventionism was already well established in the nineteenth century, what constituted the foundation of this belief system obliging one to defend moral and human(e) values in an amoral and inhumane world? The fact that the enlightenment had an

11 It need not be emphasised that this understanding outlining the basic foundation of future British-African relations was greatly influenced by the Anglocentric belief picturing Britain as a 'disinterested' party in the fight for justice and liberty.

12 Pringle (1989b), 143.

13 Bass (2008), 5. 
extraordinary effect on people's understanding of belonging to a community based on equality regardless of birth, class and race is reflected in Immanuel Kant arguing that "[b]ecause a [...] community widely prevails among the Earth's peoples, a transgression of rights in one place in the world is felt everywhere." 14 This, however, does not explain the great success of eighteenth- and nineteenth-century abolition movements; not least since a similar case of advocating our common humanity had already been made by Bartholemé de las Casas in In Defence of the Indians (1485) stating that

From the fact that the Indians are barbarians it does not necessarily follow that they are incapable of government and have to be ruled by others, except to be taught about the Catholic faith and to be admitted to the holy sacraments. [...] they wisely administered the affairs of both peace and war justly and equitably, truly governed by laws that at very many points surpass ours. ${ }^{15}$

According to François Jullien, the invention of universal human rights forming the basis of humanitarian interventionism was a highly fortuitous event. ${ }^{16}$ In strikingly similar wording Christopher Brown avers that "in key respects the British antislavery movement was a historical accident, a contingent event that just as easily might never have occurred." 17 The fact that these events however did take place is largely attributed to "the power of a newly unshackled free press that could report on foreign atrocities; [...] a free society that could react with horror at those atrocities; and politicians inside and outside the government jockeying for political power by trying to capture that public passion." 18 In other words, the foundation and subsequent success of international interventionism as illustrated in the British antislavery movement depended on four things:

In the first place, the enslavement of Africans had to be considered, in the abstract, a moral wrong. Second, that moral wrong had to attain political significance; [...] Third, those concerned needed a way to act, a way to address the concerns that had emerged. And fourth, specific individuals and groups had to make a confrontation with the slave system a personal and collective mission, a priority

14 Cit. in Bass (2008), 22. (original emphasis)

15 Cit. in Ishay (2004), 76. (my emphasis)

16 See Jullien (2008), 3.

17 Brown (2006), 30.

18 Bass (2008), 6. 
that lasted beyond initial protests and could sustain itself with coherent organization and institutional commitment. ${ }^{19}$

Such deliberations not only support Ishay's claim that "the international language of power and the language of resistance were simultaneously born in the cradle of European Enlightenment," 20 but also corroborate the contention that British/European abolitionism and humanitarianism first and foremost constituted a formalised technique for national self-introspection (defining the moral wrong) that was then later used to legitimate direct international intervention in form of personal and collective missions. So in summary, the end of the eighteenth century saw the rise of a humanitarian ideology which rested (and still rests) on three piers: (a) the stipulation of universal human rights, (b) resulting in the Others' objectification as victim, (c) consequently justifying political and moral intervention. ${ }^{21}$

To explain how the stipulation of universal human rights is connected to the objectification of the Other, one has to go back to Las Casas and Kant. What stands out is that both in their claims emphasise and defend Europe's claim of possessing superior moral qualities. What is more, despite the fact that Las Casas's defence of morality is based on (universal) religious beliefs while Kant's claim is supported by the concept of (universal) human rights, both arguments stipulate a "collective reason of mankind" that allows for a formalised representation of the object, the Other, according to cultural conventions inherent to the observing subject. This shift from immediate to formalised sensation, from presentation to representation is reflected in "the movement from matter to form in the representation of the object," 22 from what is represented to how "the what' is represented. As a consequence, the Other, who had formerly been regarded as "an unknown quantity - I would even say a mystery"23, was now successfully domesticated and de-mystified. This change in (re)presentation resulted in a permanent relegation of the 'subjected subject' to the realm of an object depending on a subject for representation. One only has to remember Karl Marx's contention regarding the Orient's incapability of representing itself:

19 Brown (2006), 29. (my emphasis)

20 Ishay (2004), 8.

21 See Hours (2008), 14-5.

22 Lloyd (1991), 65-6.

23 Kapuściński (2008), 15. 
"They cannot represent themselves; they must be represented."24 The justification for humanitarian intervention came to rest on a similar assumption legitimating colonisation on grounds of religious and moral education: 'The colonised cannot help/educate themselves; They must be helped/educated'. As Ryszard Kapuściński has pointed out, "the thinking and morality of Europeans had started to change" at the turn from the eighteenth to the nineteenth century and "people no longer spoke of 'colonialism', but of 'the mission to civilise', 'conversion' or 'bringing help to poor, backward people'.”25

In analysing Pringle's "Pangola: An African Tale" and reading it against Pringle's colonial experiences related in Narrative of a Residence in South Africa, this paper will (a) try to find out about how this formalised objectification of the colonised based on humanitarian principles is used in a story depicting a slave's (active) resistance against the colonial order. On a second level this analysis will (b) show that as every "human individual is shaped in the process, in relations, in connection with Others" 26 the representation of the Other often reveals more about the observer him/herself than about 'the object' observed. This ambiguity of representation will then (c) be explained adapting Tayeb Salih's concept of the "divided man"27 - resembling the colonised, who is both drawn to and rejected by the two opposite poles of colonial society, the 'old' tradition of the colonised and the 'new' modernity of the coloniser, both of which he can never fully regain nor obtain - to outline the benevolent coloniser's underlying predicament, at one and the same time striving to preserve and conserve while acting as an arbiter of change reshaping the colony according to European custom and norm.

\section{Storifying Rebellion as an Act of 'Self-Absolution'}

In the many years slavery existed in the Cape (1652-1834) there were only two reported slave rebellions, one in 1808 shortly after the abolition of the slave trade, the other in 1825 after numerous ameliorative measures had been introduced to limit the masters' power over their slaves. Both revolts were of a minor scale and immediately

24 See Said (2003), 21.

25 Kapuściński (2008), 28.

26 Kapuściński (2008), 44.

27 See Lloyd (1991), 78. 
suppressed, its instigators severely punished, that is, tortured, beheaded and their severed heads publically displayed as a warning to other slaves. ${ }^{28}$ Nevertheless, it needs to be remembered that in contrast to the West Indian slave system which depended on the importation of 'chattel slaves', the Cape knew different forms of slavery. So in addition to (chattel) slaves imported from abroad (usually from Malaysia, Madagascar, Mozambique, or West Africa) the 'Hottentots', although free, were often exposed to similar if not worse conditions than slaves, as Pringle in his Narrative points out: "by the colonial laws and usages, they [the 'Hottentots'] were [...] deprived of a right to the free disposal of their own labour, and reduced to a condition of degrading, grinding, and hopeless bondage, in some respects even more intolerable than colonial slavery of the ordinary description." ${ }^{29}$ However, the eponymous hero of "Pangola" is neither an imported 'chattel slave' nor a dependent 'Hottentot' but a captive 'Bushman', thus introducing and objectifying a 'new' subject according to established guidelines of representation.

\section{a) Formalised Objectification}

Pangola was one of the herdsmen of Diederik Kruger, a veeboor, or grazier, of the Tarka. He had been made captive in early boyhood, with other children of a Bushman Kraal, in one of the frequent incursions or commandos [...] undertaken by the Christian Colonists against the native tribes. The Kraal of Pangola's kindred had been surprised; and, according to the usual practice, the whole of the adult males, with the exception of a few who escaped among the precipices, were slaughtered. The women and children were carried into the Colony, and became 'hewers of wood, and drawers of water', to the captors. ${ }^{30}$

The story's introductory paragraph presents Pangola as a victim, an object lacking agency. After emphasising his captive state and his dependency on his master, his slaughtered relatives are remembered as never having done anything actively. This general absence of agency is also mirrored in the passive verb constructions dominating the introductory paragraph. What is more, in addition to being held captive and exploited by his master Pangola is later also shown to be 
treated as an 'object' by other 'objects': he is not 'spared by those of his own race - for slaves are almost always tyrants to those below them." 31 Finally, while the introductory paragraph likens captured 'Bush(wo)men' to the natural environment which they are made to exploit as 'hewers of wood, and drawers of water', Pangola in his position as voor-looper is modelled on the "cattle he runs before" as like them he "is often subjected to this terrible lash" which "in the hands of an African Colonist, can slash through the hide of a bullock deep into the mangled flesh at every stroke." 32 What is interesting, apart from the fact that the first two paragraphs characterise Pangola as an inactive and subservient creature not much different to the tame cattle he has to look after, is that this image changes dramatically once Pangola crosses the boundaries of what constitutes his place in colonial society. It is Pangola's peculiar "love of liberty and impatience of oppression common to his persecuted race, though long extinguished in the more apathetic bosom of the subdued colonial Hottentot" 33 that brings him into conflict with Van Bronkhorst, the veld-cornet. This episode is important in two respects: (1) in speaking his mind Pangola breaks down the wall of his passive and silent servitude, and (2) this physical (re-)awakening is then followed by a change of animal metaphor. But while his defence against Van Bronkhorst's accusation is still rendered in indirect speech, that is, filtered through the mind of the narrator -

he told the furious Van Bronkhorst [...] that he was a man as well as he; that God had made them equal; and though the white man had seized the land, and enforced the labour of his countrymen, yet no law either of God or man had condemned them to submit to indignities which even the slaves of the Christians would not tamely endure. 34

- the punishment of Van Bronkhorst "falling upon him with his agter-os-Sjambok (a tremendous whip of rhinoceros hide, used for urging on the draught oxen in difficult emergencies)" culminates in the strong ox weakly "writhing in the dust" like a "skotched snake." 35 This passage is central as the sexual weakness implied in the image 
of the castrated bull is now amplified by a form of physical weakness. ${ }^{36}$ But it is this state of absolute weakness that enables Pangola to see his situation with different eyes. As Fanon pointed out,

Confronted with a world ruled by the settler, the native is always presumed guilty. But the native's guilt is never a guilt which he accepts; it is rather a kind of curse, a sort of sword of Damocles, for, in his innermost spirit, the native admits no accusation. He is overpowered but not tamed; he is treated as an inferior but he is not convinced of his inferiority. He is patently waiting until the settler is off his guard to fly at him..$^{37}$

Pangola having unsuccessfully 'flown at' the veld-cornet to defend his manhood is only left with one option: outright rebellion. ${ }^{38}$ As the narrator sums up, the "impatience of injury, which ennobles the freeman, is fatal to the slave. [What] might have dignified the character of a British peasant, [...] only led the unhappy Bushman to destruction. It rendered him an outlaw and a criminal." 39

But Pangola's rebellion is of a peculiar kind, for at first he does not take revenge for the wrongs inflicted by Van Bronkhorst, but rather rejects colonisation as such. ${ }^{40}$ Leaving behind his wife and children the "child of the Desert" 41 flees into the wilderness, where, like a predator, he hides among rocks and lies in wait for wild animals to chase after for meat. It is only after forming and leading a band of fugitives that Pangola renews contact with the coloniser stealing "cattle and horses, and occasionally arms and ammunition" but "abstain[ing] from bloodshed."42 Nevertheless, only upon con-

36 It is worth pointing out that the OED defines an ox as "a castrated bull used as a draught animal" thus adding additional emphasis on Pangola's (sexually) subjected state. Soanes/Stevenson (2003), 1259. This choice of metaphor is all the more interesting as Pangola married a 'Hottentot' woman - the display of Sartjee Baartman as the 'Hottentot Venus' on the British Isles and Europe (1810-15) resulted in the eroticisation of 'Hottentot' women due to their "quintessential buttocks" denoting female sexuality - and fathered numerous children. See Lindfors (2001), 56-62.

37 Fanon (1967a), 41.

38 Sartre put it similarly, "when a people has no choice but how it will die; when a people has received from its oppressors only the gift of despair, what does it have to lose? A people's misfortune will become its courage; it will make, of its endless rejection by colonialism, the absolute rejection of colonization;" Sartre (2003), 25.

39 Pringle (1989a), 159.

40 This thought is based on Sartre's notion of the rebel's "absolute rejection of colonization." Sartre (2003), 25.

41 Pringle (1989a), 160.

42 Pringle (1989a), 160. 
fronting his former colonial master (Kruger) does Pangola achieve full agency as mirrored in his use of direct speech:

Nay, myn baas! [...] the past can never be forgotten. That day, when I lay prostrate under the agter-os-Sjambok, - you and your kinsman Bronkhorst may forget it, but I, never. Never more shall I cringe under the white man's lash; never more eat the bread he offers, embittered by this contempt. Hunger, thirst, nakedness, I can bear as my fathers have borne. I can live like the wild hound of the desert; but not like the household dog of your kraals, to be fed, and scorned, and fettered, and beaten at your pleasure. Your commandoes have indeed dispersed my tribe and destroyed my kindred; but the wilderness and its wild freedom are still my heritage, and I will never yield them again but with my life. ${ }^{43}$

Pangola's short speech is interesting as in positioning himself in opposition to the "Bushmen $\operatorname{dogs}$ " 44 he is able to regain his former freedom as symbolised by the wild hound peacefully roaming the desert. His final remark, however, foreshadows the tragic ending of the story and his final transformation into an altogether different 'animal'. Trapped and betrayed by his own countrymen, Pangola, "mortally wounded, $\mathrm{fl}[\mathrm{i}] \mathrm{ng}[\mathrm{s}]$ himself like a hunted leopard upon his ancient foe the veld-cornet, and stab[s] him twice in the throat with his poisoned assegai." 45 Having tasted freedom Pangola prefers death to captivity and finds solace in killing his former enemy: "I die in arms against the Christians - the murderous Christians who destroyed my race. I have repaid some of my wrongs - I have slain my old oppressor - I have shown an example to my countrymen - and now let me die without disturbance." 46 It is this hurried and only partial solution of the story's central conflict that foregrounds the formalised practice of relating colonial affairs. In blaming the conflict on the savagery of some malignant colonists - if it had not been for Bronkhorst's sheer brutality Pangola would never have rebelled and questioned the legitimacy of colonisation, would never have transformed back into a wild and dangerous leopard from a tamed and demystified draught animal - the colonial enterprise's benevolence of 'enlightening those who have not yet seen the light' is kept intact.

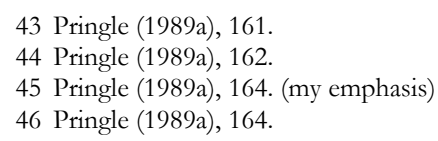


Thus the story's critique of slavery is one of finding easy solutions to complex problems, punishing the wicked veld-cornet while praising the humanitarianism of the slave master: "Kruger was naturally a kind-hearted man, and much more humane to his swarthy dependents than most persons of his class." ${ }^{47}$ In loading all evils onto a scapegoat the present power structures are not criticised and the colonial elite protesting their innocence can unashamedly continue to enjoy the sweet benefits of colonial life. 48

b) Self-Revelatory Aspects Underlying the Process of 'Objectification'

There is not a negro from the coast of Africa who does not [...] possess a degree of magnanimity which the soul of his sordid master is too often scarce capable of conceiving. Fortune never exerted more cruelly her empire over mankind, than when she subjected those nations of heroes to the refuse of the jails of Europe, to wretches who possess the virtues neither of the countries which they come from, nor of those which they go to, and whose levity, brutality, and baseness, so justly expose them to the contempt of the vanquished. ${ }^{49}$

As noted earlier, the formalised language underlying the representation of the 'object' often reveals more about the group making the observation than about the 'object' observed. On this level we have to focus on what Niklas Luhmann calls latency observation, a critical analysis that "deliberately chooses a negative version and distinguishes itself from the observing observation by this very negativity; in other words, when it wants to observe what another observation does not observe, or, to radicalize the issue, when an observation specializes in observing what another observer is incapable of observing." 50 It is through this process of un-silencing muffled aspects of the process of representation that we can make visible the self-revelatory message underlying the representation of the Other.

As Pereira and Chapman have outlined, Pringle although "harsh in his condemnation of colonial policies and practices, $[. .$.$] is always$ prepared to distinguish between enlightened and despotic behaviour

47 Pringle (1989a), 159.

48 In this respect Pringle's "Pangola" is similar to Maria Edgeworth's "The Grateful Negro". See Knapp/Pallua (2008), 14-20.

49 Smith (2002), 242.

50 Luhmann (2000), 83. 
in individuals, whether black or white, British or Boer." 51 This critical stance allows Pringle to create a space between the coloniser and the colonised, the master and the slave, whence he can castigate the colonial situation on high moral grounds. As his attack of the colonial government shows - "the long-abused Aborigines of South Africa have [...] gained but little by the transfer of the Cape from Dutch to English dominion; [...] under the Dutch they were plundered, and oppressed by the boors; under the English by the Government itself' 52 - the indigenous population has not yet benefited from innately British values such as liberty, justice and benevolence. Put into Fanonian terms, British occupation has not yet succeeded in "promot[ing] the machine-animal-men to the rank of men" 53 despite prohibiting British settlers from owning slaves. ${ }^{54}$

However, if one reads Pringle's short story against the story of Dragoener's revolt related in his Narrative, one is confronted with an entirely new dimension of the story. Both narratives, "Pangola" and the story of Dragoener, are set in the Tarka of the Eastern Cape and Pringle in both 'stories' explicitly legitimates and defends rebellion, in the Narrative claiming that the indigenous population had "suffered wrongs against which the heart and soul of man naturally revolts, and which in fiery natures tend to awaken the thirst of vengeance." ${ }^{5}$ In the Narrative Pangola's fate is mirrored in Dragoener, "a tame Bushm[a]n [...] who, on being flogged on some occasion by a kinsman of his master's, with an agter-os-sjambok (a tremendous whip of rhinoceros hide), [flees] to the desert, and sw[ears] eternal enmity to the colonist." ${ }^{56}$ But in contrast to "Pangola" where the colonial authorities at length form a commando "to extirpate this desperate band of freebooters" 57 it is Pringle himself who in the Narrative calls for a commando to capture Dragoener despite having earlier criticised such commandos' indiscriminate slaughter of indigenous peo-

51 Pereira/Chapman (1989), xxvi.

52 Pringle (1989c), 149.

53 Fanon (1967b), 220.

54 See Armstrong/Worden (1988), 109-183; Watson (1990), 9-29.

55 Pringle (1966), 223. For a direct justification of revolt in "Pangola" see the epigraph of this paper.

56 Pringle (1966), 222. Also note the similar wording used in "Pangola" as outlined earlier.

57 Pringle (1989a), 162-3. 
ple. ${ }^{58}$ It is precisely in this respect that "Pangola," according to Damian Shaw, "can be read [...] as Pringle's attempt to exorcise his own guilt [in the killing of Dragoener] and to use his own pen as a poisoned barb in defence of the oppressed, even though he had been complicitous with the oppressors." 59 This complicity becomes evident in his justification for calling for action against the band of banditti led by Dragoener:

however guilty the colony may have been in pursuing a system of injustice and oppression which had, directly or indirectly, driven most of these unhappy outlaws to their present mode of life, it was obvious that their predatory career could not be allowed to continue. Neither could the boors, some of whom boasted that only a few years ago they used to lie in wait for the Bushmen, and shoot them like baboons, be permitted to resume their old habits of murderous private retaliation. I wrote to the landdrost, urging that some plan should if possible be devised, combining protection to the colonists with mercy to the outlaws, for putting an end to this state of things. ${ }^{60}$

This form of guilt expiation gains additional significance if considered in connection with Pringle's Scottish roots. Sir Walter Scott's introduction of the MacEaghs, a Highland Scottish clan, in The Legend of Montrose appears to be useful in this respect. Considering how similar Scott's MacEaghs - "outlawed and persecuted [...] and every man's hand being turned against them, their hand was of course directed against every man" 61 - are to Pringle's freebooters - they "might have been able, perhaps, to make out a good case against the colony, had they been heard in their own defence" 62 - it becomes clear that Pringle in his admiration of the Scottish rebels at least partly identified with the revolting 'Bushmen'. As a result, in reporting his South African 'hero(es)' to the landdrost he not only betrays

58 As Pringle reports, one commando when returning home observed "a Bush-woman was observed [...] lying near the path, wrapped up in her caross, apparently asleep. The commander, without uttering a word or asking a question, levelled his musket and fired. The caross heaved up - and an aged female, in the agonies of death, rolled out of it. And the party rode on, without considering the matter worthy even of a passing remark!" Pringle (1966), 230; also see Pringle (1966), 333-4.

59 Shaw (1998), 55.

60 Pringle (1966), 223.

61 Cit. in Shaw (1998), 53.

62 Pringle (1966), 223. 
his own ideal of freedom personified in the rebel(s) but also denounces his own Scottish ancestors recalcitrantly resisting the overpowering and dominating English invader.

With this in mind it has to be questioned whether Pringle's renditions of colonial corruption and depravity are really driven by, what Gary J. Bass calls, "a genuine sense of humanity." 63 Is Pringle really able to resist the temptation of using "Human rights [...] as an alibi," of referring to rights belonging "to the juridical and moral superstructure" for mere "[self-] advertising"? 64 The answer to this question is hinted at in John Fairbairn's praise assigning Pringle a "place amongst the most intrepid and generous defenders of the natural rights of mankind." 65 What Pringle seems to be congratulated for is his staunch defence and vindication of European rights in a colony forcefully subjugated to European rule. Fairbairn's praise thus puts Pringle's "reformist liberalism [disguised in] 'humanitarian romanticism"' into a different picture, highlighting the liberal's role as an interested "conciliator between oppressor and oppressed." 66 This 'new' insight on humanitarian interventionism justifying colonisation casts a different light on the benevolent coloniser, the "noble adventurer [and] righteous pioneer [...] laboring selflessly for mankind, attending the sick, and spreading culture to the nonliterate." ${ }^{67}$ Even if Pringle's myth enables the benevolent coloniser to perform and act of "self-absolution" 68 his doubly illegitimate usurpation can still not wash away the fact that "the more freely he [the coloniser] breathes, the more the colonized are choked" 69 in matters personal, cultural and spiritual. In this respect, to refuse colonisation one has either to "withdraw[...] physically from those conditions or remain[...] to fight and change them." ${ }^{\prime 70}$ But just as a parent resisting the role of parenthood will encounter ambiguous feelings of love and hate for the

63 Bass (2008), 19.

64 Jean Baudrillard cit. in Bass (2008), 16.

65 John Fairbairn in the South African Commercial Advertiser of 18 March 1835, cit. in Robinson (1966), xvii.

66 Nosipho Majeke, The Role of the Missionaries in Conquest, cit. in Gordimer (2003), 36; also see Memmi (2003), 65.

67 Memmi (2003), 47.

68 Sartre (2003), 22.

69 Memmi (2003), 52-3.

70 Memmi (2003), 63. 
abandoned child, ${ }^{71}$ a coloniser resisting colonisation will end up a divided man: ${ }^{72}$ Pringle, "himself a settler, hunter and colonist, [in this respect] articulates the classic dilemma of the liberal humanist, decrying the system of which he is, irrevocably, part." 73

\section{c) The Benevolent Coloniser's Predicament as a 'Divided Man'}

Without undervaluing the exertions of other missionaries of various denominations, whose services have been in an eminent degree meritorious and beneficial in those remote regions, I may justly call Dr. Philip the Las Casas of Southern Africa - and happier than Las Casas, in as much as in promoting at once the political and spiritual redemption of the Native Race, he has aided also in breaking the bonds of the Negro, and smoothed the way to the moral conquest of Africa.74

Pringle's praise for Dr. Philip's positive influence on Southern Africa highlights the underlying predicament of the missionary who in "promoting [...] the political and spiritual redemption" and "breaking the bonds" of the colonised is directly responsible for the latter's subjection to colonial power. The phrase "moral conquest" is particularly important in this respect as moral values constitute the foundation of a society's perception of what is right and wrong. So in conquering a people's moral faculties, the coloniser takes power through the back door, that is, by substituting a people's former moral code for a new one, now self-righteously pulling the strings of the 'colonised puppet'. This moral conquest is made by a "moral hero" 75 who propagates his own innocence by giving "himself absolution." 76 In "Pangola" this position is taken up by Kruger, Pangola's benevolent master, "whose more humane disposition would have averted or mitigated" 77 Bronkhorst's cruel punishment. It is in this

71 The comparison to parenthood is even more telling if one puts parental obligations into a colonial context substituting the parent for the benevolent colonial master.

72 As Memmi outlines, "he [the colonizer who refuses] lives his life under the sign of a contradiction which looms at every step, depriving him of all coherence and all tranquillity. What he is actually renouncing is part of himself, and what he slowly becomes as soon as he accepts a life in a colony. He participates in and benefits from those privileges which he half-heartedly denounces." Memmi (2003), 64.

73 Pereira/Chapman (1989), xvi.

74 Pringle (1966), 324. (my emphasis)

75 Memmi (2003), 67.

76 Memmi (2003), 120.

77 Pringle (1989a), 160. 
context that the contention that Pringle "was no mercenary, though an official advocacy of the rights of the African race"78 has to be understood. Although Pringle did not participate in a war appropriating land formerly owned by other people, he in fighting for the rights of Africans according to European law and custom took up the role of a 'cultural' and moral mercenary. As Walter Benjamin made clear, "There is no document of civilisation which is not at the same time a document of barbarism; barbarism taints alone the style in which it was transmitted from one owner to another." ${ }^{\prime} 9$ Thus even if he were to join forces with the colonised, the benevolent coloniser (who refuses) cannot escape from the inevitable epistemological dilemma troubling his conscience as he is "both a revolutionary and an exploiter." ${ }^{80} \mathrm{He}$ can

either liken[...] the colonial situation to any other and therefore apply[...] to it the same analytical methods, judging it and the colonized in accordance with traditional values; or he must consider the colonial juncture as being original and abandon his values and usual habits of political thought which induced him to take sides. In other words, either he no longer recognizes the colonized, or he no longer recognizes himself. ${ }^{81}$

This dilemma illustrates that "the colonial condition cannot be adjusted to; [that] like an iron collar, it can only be broken." 82 In this respect, the colonising master and the colonised slave have to recreate themselves outside the colonial situation. The master has to confront his image as "an oppressor, a partial, unpatriotic and treacherous being, worrying only about his privileges and their defense" just as the slave has to free himself from the image of "an oppressed creature, whose development is broken and who compromises by his defeat." ${ }^{3}$ Thus the revolt envisioned has to be nothing less than a 'cultural and epistemological revolution'.

Pringle, however, offers a different 'solution' to this predicament. As outlined earlier, himself a colonizer he skilfully constructs a myth that allows him to position himself as an intermediary between

78 Mr. M'Donald cit. in Conder (1966), xxxviii.

79 Walter Benjamin cit. in Ishay (2004), 2.

80 Memmi (2003), 67.

81 Memmi (2003), 76.

82 Memmi (2003), 171-2.

83 Memmi (2003), 133. 
the coloniser and the colonised, the cruel slave owner and the obsequious slave. In other words, he takes on the role of the 'moral mercenary' criticising both 'partners of colonisation'. In so doing, Pringle evades the state of a divided man taking refuge in a transcendental, abstract argument of justice and rights that mirrors the movement from a struggle for (universal) religious beliefs to one for (universal) human rights; the latter being abstract enough to give both parties (the coloniser and the colonised, the master and the slave) the feeling to be in control of their thoughts and actions. This aspect is all the more important when one considers that in "Pangola" this allegedly disinterested moral ground is personified by the nameless English officer who in his gentlemanly behaviour - he "humanely offer[s] to have [Pangola's] wounds examined" 84 - starkly contrasts the slave-owning Dutch/Afrikaner veld-cornet's monstrous character, ${ }^{85}$ thus establishing a direct link between correct moral conduct and the domain of benevolent English values.

\section{Conclusion}

Pringle [...] presents, in microcosm, many of the issues which have dominated the South African scene for the past 150 years. The problems he wrestled with - racial conflict, political oppression and censorship, economic exploitation - are equally relevant today. ${ }^{86}$

It was once averred that in "seeing Africa as a landscape of societies, communities and human beings, Pringle [...] [d]espite the occasional hint of Rousseau-like idealism, [tried] to explode the myth of 'darkest Africa'." ${ }^{87}$ Pringle certainly tried, but did he also succeed? All in all, while touching upon issues of slavery and colonial oppression, Pringle although criticising the present dispensation does not succeed in transcending or transforming it. Pringle's innovative approach of 'disinterested side-taking' is flawed in at least two respects. As Calder mentioned, Pringle's poem “'Makanna's Gathering' [...] shows how consciousness of warlike Border traditions, and sympa-

84 Pringle (1989a), 164.

85 Quite tellingly Bronkhorst threatens to kill the 'Bushman' spy if he refuses to betray his countrymen and take a message to the rebels. Pringle (1989a), 163.

86 Pereira/Chapman (1989), xii.

87 Pereira/Chapman (1989), xxiv. 
thy for cattle-raiding Gaels, permitted him [Pringle] to identify with warlike Xhosa." 88 On a similar ground Pringle creates a bond between the revolting slave and the benevolent coloniser (who refuses). But while Pringle re-imagines the Scottish past in 'cattle-raiding Gaels' he imposes his feelings of nostalgia onto a situation which appears similar on the surface but has significant differences when put in historical context. Most importantly, in siding with the revolting slave Pringle in essence revolts against himself and his selfish exploitation of opportunities constitutive of colonial society. In this respect it does hardly surprise that Pringle is unable to escape his own prejudices and paternalism as they constitute the core element and foundation of his 'romantic humanitarianism' emphasising how slavery and colonial oppression in breeding violence are deleterious in rescuing Africans (and colonists) from their degraded state.

The frontier colonists, be they Dutch or British, must of necessity continue to be semi-barbarians, so long as the commando system the system of hostile reprisals - shall be encouraged or connived at; [...] and year after year, while we continue to talk of our boundless benevolence and our Christian philanthropy, fresh loads of that guilt which the Almighty has denounced in awful terms - the blood-stained guilt of oppression, will continue to accumulate upon our heads as a nation. ${ }^{89}$

As this quote reveals, Pringle regarded 'boundless benevolence and Christian philanthropy' to be the most important articles of British export. Read against the stories of Dragoener and "Pangola" Pringle's own desperate call for a commando after criticising its brutal violence however shows that the most generous paternalism despite being founded on benevolence and philanthropy is nothing but a "charitable racism" which does not automatically vanish "as soon as the colonised [questions the present order and] demands his own $[\ldots]$ rights" 90 but will rather more often support and justify the complete extinction of the revolting colonised seeking selfdetermination.

What remains to be questioned is whether Pringle guilt-ridden in his 'betrayal' of the freedom-seeking rebel did not actually picture 
his own destiny in the treacherous 'Bushman' informing on the rebels, not least since the punishment inflicted evokes connotations of self-castigation: "Two arrows of polished reed, thrust though the flesh of the wretch's cheeks, projected like the tusks of the African wild hog, while their barbed points, embued in deadly poison, where infixed on the tongue that had betrayed his kinsmen to their pursuers." 91 This partly comic image of the traitorous 'Bushman' reappearing from the bushes transformed into an 'African wild hog' is contrasted to Pangola's grim smile when he sees the dead "bloated body of the spy" 92 amidst his dying European enemies. If one reads "Pangola" along these lines then the internal conflict resulting from one's disappointed rejection of 'humanitarian romanticism' can only be resolved by one's physical escape from the colony and its depravity. While Pringle's physical escape only required him to leave the colony for Britain, Pangola/Dragoener's only option was to face death by the hand of the oppressor.

\section{Works Cited}

Armstrong, James C./Worden, Nigel A. (1988): “The Slaves, 1652-1834," in: Elphick, Richard/Giliomee, Hermann, eds.: The Shaping of South African Society, 1652-1840. Middletown, CT: Wesleyan University Press, 109-183.

Bass, Gary J. (2008): Freedom's Battle: The Origins of Humanitarian Intervention. New York: Alfred A. Knopf.

Brown, Christopher Leslie (2006): Moral Capital: Foundations of British Abolitionism. Chapel Hill: University of North Carolina Press.

Calder, Angus (1982): "Thomas Pringle (1789-1834): A Scottish Poet in South Africa," in: English in Africa 9 (1), 1-13.

Chapman, Michael (2003): Southern African Literatures. Pietermaritzburg: University of Natal Press.

Conder, Josiah ([1835] 1966): “A Biographical Sketch of the Author," in: Pringle, Thomas: Narrative of a Residence in South Africa. Cape Town: C. Struik, xxi-xl.

Fanon, Frantz (1967a): The Wretched of the Earth. Trans. Farrington, Constance. London: Penguin.

Fanon, Frantz (1967b): Black Skin, White Mask. Trans. Markmann, Charles Lam. New York: Grove Press. 
Gordimer, Nadine (2003): "New Introduction," in: Memmi, Albert: The Colonizer and the Colonized. London: Earthscan, 27-44.

Hours, Bernard (2008): "Moral und Tränen Incorporated: Eine Kritik der humanitären Selbstgewissheit," trans. Rüenauver, Uta, in: Le Monde Diplomatique September, 14-5.

Ishay, Micheline R. (2004): The History of Human Rights: From Ancient Times to the Globalization Era. Berkeley: University of California Press.

Jullien, François (2008): "Die Erfindung der Menschenrechte: Vom Kampfbegriff zum Universalwerkzeug," trans. Adrian, Michael, in: Le Monde Diplomatique April, 3-4.

Kapuściński, Ryszard (2008): The Other. Trans. Lloyd-Jones, Antonia. Introd. Ascherson, Neal. London and New York: Verso.

Knapp, Adrian/Pallua, Ulrich (2008): "Images of Africa(ns): Racism and Ethnocentricity in the British Abolition Debate, 1787-1834," in: Innsbrucker Diskussionspapiere ₹u Weltordnung, Religion und Gewalt 26, 1-22.

Lindfors, Bernth (2001): "Hottentot, Bushman, Kaffir: The Making of Racist Stereotypes in 19th-Century Britain," in: Palmberg, Mai, ed. (2001): Encounter Images in the Meeting between Africa and Europe. Uppsala: Nordiska Afrikainstitutet, 54-75.

Lloyd, David (1991): "Race and Representation," in: Oxford Literary Review 13, 62-94.

Loos, Jackie (2004): Echoes of Slavery: Voices from South Africa's Past. Claremont: David Philip.

Luhmann, Niklas (2000): "Observation of the First and of the Second Order," in: Luhmann, Niklas: Arts as a Social System. Trans. Knodt, Eva M. Stanford: Sanford University Press, 54-101.

Mason, John Edwin (2003): Social Death and Resurrection: Slavery and Emancipation in South Africa. Charlottesville: University of Virginia Press.

Memmi, Albert (2003): The Colonizer and the Colonized. Trans. Greenfeld, Howard. London, Earthscan.

Pereira, Ernest (1992): “Thomas Pringle: An Introductory Guide," in: Chapman, Michael/Gardner, Colin/Mphahlele, Es'kia, eds.: Perspectives on South African Literature. Parklands: Ad. Donker, 1-18.

Pereira, Ernest/Chapman, Michael, eds. (1989): African Poems of Thomas Pringle. Pietermaritzburg: University of Natal Press.

Pringle, Thomas (1966): Narrative of a Residence in South Africa. Cape Town: C. Struik.

Pringle, Thomas (1989a): "Pangola: An African Tale," in: Pereira, Ernest/Chapman, Michael, eds.: African Poems of Thomas Pringle. Pietermaritzburg: University of Natal Press, 159-164.

Pringle, Thomas (1989b): "Letters from South Africa, No. I - Slavery," in: Pereira, Ernest/Chapman, Michael, eds.: African Poems of Thomas Pringle. Pietermaritzburg: University of Natal Press, 140-148. 
Pringle, Thomas (1989c): "Letters from South Africa, No. II - Caffer Campaigns - The Prophet Makanna," in: 149-156.

Robinson, A. M. Lewin (1966): "Introduction," in: Pringle, Thomas: Narrative of a Residence in South Africa. Cape Town: C. Struik, ix-xvii

Said, Edward (2003): Orientalism. 25 th Anniversary Edition. New York: Vintage.

Sartre, Jean-Paul (2003): "Introduction," in: Memmi, Albert: The Colonizer and the Colonized. London: Earthscan, 17-25.

Shaw, Damian (1998): “Thomas Pringle's 'Bushmen': Images in Flesh and Blood," in: English in Africa 15 (2), 37-61.

Smith, Adam (2002): The Theory of Moral Sentiments. Haakonsen, Knud, ed. Cambridge: Cambridge University Press.

Soanes, Catherine/Stevenson, Angus, eds. (2003): Oxford Dictionary of English. $2^{\text {nd }}$ ed. Oxford: Oxford University Press.

The Times, 3 Dec. 1824, 2. The Times Digital Archive 1785-1985.

Watson, R. L. (1990): The Slave Question: Liberty and Property in South Africa. Hanover and London: University Press of New England. 



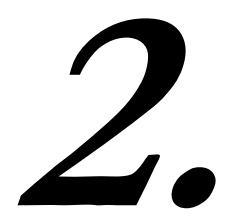

\section{De-Silencing Historical Testimonies}



Religion, Liberty, Violence, and Resistance in the Writings of
Two Early Female Abolitionists

Judith Jennings

\section{Introduction}

Between 1772 and 1807 thousands of men, women, and children throughout Great Britain learned about the distant realities of the African slave trade, formed opinions, and became change agents to end this horrifying but long-sanctioned commerce. As researchers in an innovative project at the University of Innsbruck have recognised, essays, tracts, broadsides, plays, novels, and poems played key roles in this major paradigm shift in public discourse and policy relating to slavery and the slave trade. The Innsbruck project, English Literature and Slavery, 1772-1834: From the Beginning of the Abolitionist Movement to the Abolition of Slavery, focuses on reappraising this discourse by analysing the rhetorical and aesthetic strategies in texts of different genres and by closely studying the argumentative areas employed. The team of the Innsbruck project ${ }^{1}$ has identified six parameters or argumentative areas in the abolition literature they analysed: racial/ethnic, religious, economic, legal/human rights, humanitarian, and national. In addition, the Innsbruck project has called attention to the importance of images of power, resistance, and violence in slavery discourse, providing another important path to understanding texts about human enslavement.

My previous research has documented the anti-slavery sentiments and writings of two long-time friends, talented artists, and 
opinion leaders in late eighteenth-century England, Mary Morris Knowles and Anna Seward. ${ }^{2}$ Using the parameters identified and looking at literary images of power, violence, and resistance provides fresh perspectives and raises new questions about the lives and writings of these early female abolitionists. How did these women both reflect and contribute to the public paradigm shift regarding slavery and the slave trade? What kinds of argumentative parameters did they use in their writings? Did they employ images of power, violence, and resistance? Did their private discourse concerning slavery and the slave trade differ from their writings intended for a wider readership? What new insights and paths to further research concerning women's roles in the antislavery paradigm shift emerge from analysing the life stories and writings of these two female abolitionists?

To answer these questions, this analysis foregrounds the lives and writings of the two women against the backdrop of late eighteenth-century English life and the formative stages of the male-led public campaign to end the British slave trade. In a series of significant books beginning with Writing Women's Literary History, feminist scholar Dr. Margaret Ezell demonstrates the importance of integrating historical context and literary analysis in assessing women's texts. ${ }^{3}$ The lives and writings of these two women are best understood when integrated into, not separated from, larger cultural trends and the emergence of the anti-slavery ethos. Ezell also demonstrates the importance of including manuscript as well as print texts to obtain a fuller picture of women's textual agency, so this analysis includes both kinds of writings by these early female abolitionists.

\section{Mary Morris Knowles: Religion, Liberty, and the Humanitarian Argument}

Mary Morris, born in 1733 in Rugeley, Staffordshire, came from a long line of English Quakers, dating back to the first Friends of the mid-seventeenth century. During that time of religious upheaval, Quaker founder George Fox sought truth in "the pure knowledge of God, and of Christ alone, without the help of any man, book, or

2 See Jennings (2006).

3 See Ezell (1993), (1999), Ezell/O’Keefe (1994). 
writing." Fox found his truth in the "divine light of Christ," which "shine[s] through all." For Fox, the divine light within "answers the perfect principle of God in everyone," offering a path to salvation, a guide to daily action, and true liberty." For the ministry of Jesus Christ and his teaching "bringeth into liberty and freedom," wrote Fox. Not the liberty of "the flesh," he explained, but the transformative liberty of the spirit seeking divine perfection. ${ }^{4}$

In the late seventeenth century, as religious scholar Dr. Hugh Barbour points out, some Quaker leaders like William Penn "combined Quakers' radical hope for the total transforming of men, ethics, and society by God's spirit, with a humanist's trust in reason and conscience already at work in all men universally." 5 This combination of humanitarianism and religion inspired Penn and other likeminded Quakers to seek practical social reforms, including securing political liberty to practice their religion. Quakers in Britain, for example, lobbied for and helped obtain the Acts of Toleration enabling them to establish meetings for worship and business, maintain their own birth, death, and baptismal records, and conduct marriages. ${ }^{6}$

By the early eighteenth century, when Morris was born, British Quakers were still adapting to limited toleration. Friends were free to practice their religion, but they were prohibited from taking university degrees, for example, and required to pay tithes to the Church of England. They still looked to the divine spirit within and aspired to perfection, but no longer interrupted Anglican services or went naked for a sign, as a few early Quakers had done. Some, like the Morris family, prospered under toleration and integrated into local and national life, while continuing to combine radical hopes for perfection with confidence in human reason and commitment to liberty. Growing up in a prosperous provincial family, Morris received an education grounded in both religion and reason. She read the Scriptures and early Quaker texts, but also studied science, Latin concepts, polite literature, and French, as well as learning fine handwriting and advanced needlework. She and her family did not practice the kind of social separatism that some Quakers did. Far from being 
secluded, as a young woman Morris gained a regional reputation as "the Beauty of Staffordshire."”

For Morris, spiritual liberty included choosing whom to marry and creating works of art. She refused two offers of marriage before wedding, at age 33, Thomas Knowles, an apothecary. After her marriage, she continued to practice fine needlework, despite the misgivings of some Quakers about spending time making art. Her talent came to the attention of Queen Charlotte, who asked Knowles to create a needle painting copy of a recently completed portrait of King George III. Knowles stitched such an outstanding needlework reproduction that the Queen presented her with $£ 800$, and a Birmingham newspaper publicly celebrated her accomplishment. She and her husband used the money to pay for him to study medicine at Edinburgh and then Leiden, where he earned the degree of Doctor of Physic. After that, the couple settled in London, where he became a Licentiate of the Royal College of Physicians and prospered greatly. She became a celebrated woman and popular guest in the developing cultural life of the thriving city.

As tensions mounted between Britain and her colonies, Knowles supported American liberty. In December 1774 she wrote to Catharine Sawbridge Macaulay, the well-known radical historian, sharing her concerns to protect liberty there. ${ }^{8}$ In May 1776 Knowles appeared at the now famous dinner party where Samuel Johnson, upholder of British colonial rule, met the radical pro-American politician, John Wilkes. James Boswell later described how Knowles joined the all-male company after dinner along with a leading radical politician. ${ }^{9}$ Knowles also advocated for liberty for women. At another literary dinner party in April 1778, as described by Boswell, she complained to Johnson that, "men had more liberty allowed them than women." 10 According to her account of that occasion, she engaged in a heated debate with Johnson, defending Quaker principles and the liberty of their mutual friend, Jane Harry, to change her religion. ${ }^{11}$ 
Image 1: Engraving of Mary Morris Knowles, by (first name unknown) Mackenzie, date unknown

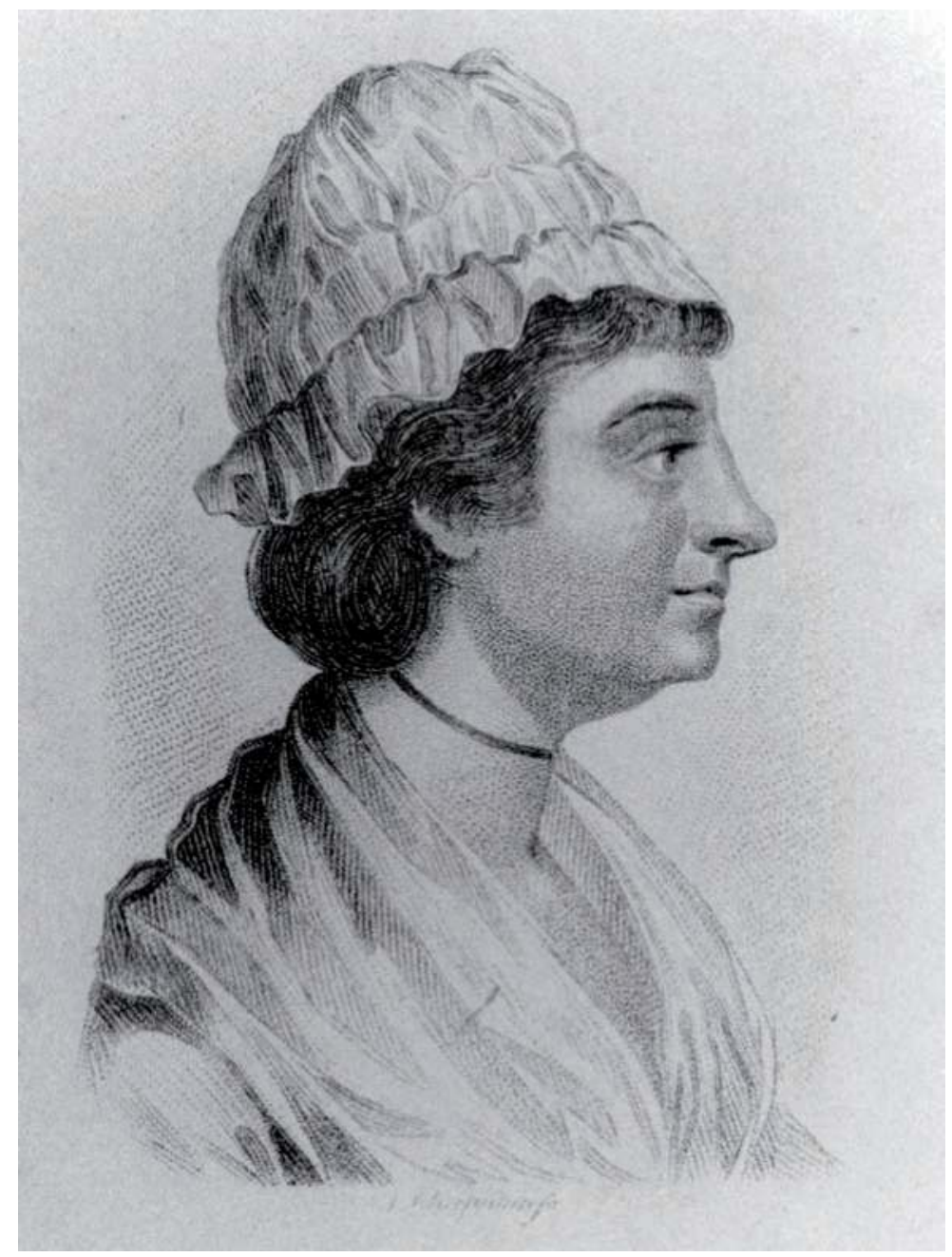

Source: Used with permission of the Haverford College Library Quaker Collection, Haverford, Pennsylvania, USA

Born in 1756, Jane, or "Jenny" as friends called her, was the natural daughter of Thomas Hibbert, an English slave trader in Ja- 
maica, and Charity Harry, described as his housekeeper and a "free mulatto." ${ }^{2}$ Like other children of affluent English fathers and Jamaican mothers, Jane and her younger sister Margaret went to England to complete their education. In late 1775 or early 1776 Margaret died at her boarding school; and Jane grieved deeply, finding no comfort in her Anglican upbringing. She turned to Knowles, a social acquaintance of her guardian, for religious guidance. After much internal turmoil, Harry resolved to become a Quaker, the decision that provoked the heated debate between Johnson and Knowles.

Knowles and Harry remained close friends as Harry's Jamaican ties brought her face to face with the realities of slaveholding. In 1780 Thomas Hibbert died in Jamaica, leaving land and slaves to Charity Harry. When Jane learned this, she resolved to return to Jamaica to plead with her mother to free the slaves she had inherited. Jane was unable to make the trip, however, because the war with America made travel to the Caribbean too difficult. In 1782 Jane Harry married Joseph Thresher, a Quaker surgeon, living in Worchester. Mary and Thomas Knowles witnessed the wedding, acting in place of her family. Less than two years later, Jane Harry Thresher lay mortally ill at age 28 , following childbirth. On her deathbed she requested her husband to pay any fees necessary to free her mother's slaves.

Thresher died before she could persuade her mother to free her slaves, yet her intention to do so was publicly announced in her obituary in Gentleman's Magazine, the most popular publication of the day. Anna Seward indicated that Knowles attended her dear friend on her deathbed, so Knowles would have known of her dying request..$^{13}$ A Quaker historian later surmised that Knowles wrote the heart-felt obituary. ${ }^{14}$ The obituary identified Thresher as a Quaker but described her accomplishments in nonsectarian and humanitarian terms. "Mrs. Thresher [...] one of the people called Quakers," it began, was "highly distinguished for clearness and understanding, accomplishments of education, amiable manners, and benevolence of heart." Likewise, it described Thresher's desire to free her mother's slaves in humanitarian terms: "Such indeed was her philanthropy, such her unlimited charity, that about three years ago she

12 Burnard/Morgan (2001), 213. Colonial Office (1775).

13 Seward (1811), vol. 1, 104.

14 See Green (1914). 
formed a design of going to Jamaica, the residence of her mother, with a view to procure the freedom of her mother's Negroes." The obituary indicated that Thresher intended, not only to obtain freedom for the enslaved Africans, but also to "instruct them in the principles of the Christian religion, for which instruction she was well qualified." Ending on a practical note, the obituary explained that, "the great commotion of public affairs frustrated her noble design. However, we are informed she has requested her husband that, if the said Negroes be liberated at her mother's decease, he will pay the premium to the island for such liberation, if any should be then required." 15

Jane Harry Thresher's obituary stands as an early public statement against slaveholding by a Caribbean-born woman of colour with family ties in both England and Jamaica. The obituary writer, most likely Mary Morris Knowles, employed inclusive humanitarian language to express Thresher's desire to free those enslaved by her family. Likewise, the references to her religion are nonsectarian and inclusive. Finally, the brief statement reflects an underlying assumption that any reasonable person would support liberty for enslaved Africans.

\section{The Male-Led Public Campaign against the British Slave Trade}

In 1783, after the end of the American Revolution and one year before Jane Harry Thresher's death, six Quaker men, including Dr. Thomas Knowles, met in London to form a secret association for the purpose of raising awareness in Britain about slavery and the slave trade. While the association was secret, most likely because of Quaker restrictions on publications, its purpose was public. Resolving that, "the public mind should be enlightened," the informal association began inserting anti-slavery articles in London and provincial newspapers. In its first year of operation, the little group often met at the Lombard Street home of Thomas and Mary Knowles. ${ }^{16}$ 
Thomas Knowles died in November 1786, but in May 1787, his five surviving colleagues from the informal association joined with Thomas Clarkson, Granville Sharp and five other Quaker men to form a committee "for procuring such Information and Evidence, and for distributing Clarkson's Essay and such other Publications, as may tend to the Abolition of the Slave Trade." As Clarkson explains in his History of the Rise, Progress and Accomplishment of the Abolition of the African Slave Trade written in 1808, the committee, after much debate, decided to focus on ending the human trade conducted by British merchants and seamen rather than tackling the much thornier question of slaveholding in the British Empire. Clarkson's essay thus became a primary tool for the London Abolition Committee, as the group came to be known. The committee published 2,000 copies of his Summary View of the Slave Trade in May 1787 and an additional 5,000 copies that summer. ${ }^{17}$

Josiah Wedgwood, already making a name for himself as a manufacturer of classic-style pottery affordable to the middling classes, joined the committee that summer. On 16 October 1787 the committee approved the design for a seal to be produced by Wedgwood. A member described the proposed seal, featuring the figure of a kneeling, enchained African male "in a supplicating Posture" encircled by an eight-word question, "Am I Not a Man and a Brother?"18 By approving this proposal, the London Abolition Committee authorised the creation of the now famous design that quickly became a popular icon for the public campaign to end the British slave trade. This seemingly simple image and text admitted many interpretations. The supplicating posture could appeal to feelings of compassion but also to tacit acceptance of the subordination of the African male. The text posed a question about the common humanity of the African male, rather than making a statement about either slavery or the slave trade. Finally, embodying African slavery in male form masked the fact that African women and children were also deeply affected by slavery and the slave trade.

On 15 January 1788 the London Abolition Committee issued its first public report, "earnestly requesting [...] the assistance of every individual in impressing on the minds of our legislatures the 
necessity of entering into a serious investigation" of the slave trade. The committee called on supporters throughout the country to present petitions to Members of Parliament. Thomas Clarkson later recalled advising supporters to look, especially, to persons with the "means of raising the public spirit."19 From Bristol, prominent Quaker industrialist Richard Reynolds answered the call. From 1763 to 1768 Reynolds headed the highly successful Coalbrookdale iron company, founded by Abraham Darby. He then formed his own highly successful Company of Ironmasters in Bristol. According to his granddaughter, Reynolds became a supporter of abolition in 1783, the first occasion on which he "came forward on any national question." Now, she said, "Another effort being made in the year 1788 on behalf of the much injured Africans, he again solicited the aid of his friends, both in and out of Parliament."20

\section{An Appeal to Women Writers}

At this critical juncture, Reynolds appealed to Sarah Kirby Trimmer, a popular Anglican educational writer in London, "though personally unknown to her." At that time, Trimmer, who became the mother of 12 children, had authored An Essay Introduction to the Knowledge of Nature (1782), the six-volume Sacred History Adapted to the Comprehension of Young Persons (1784) and The Economy of Charity (1786). According to Reynolds's granddaughter, "he addressed a letter to Mrs. Trimmer hoping that he might, through her means, influence the female sex in the cause, and also, if possible, intreat [sic] the Queen herself." In a second letter to Trimmer on 4 February 1788, Reynolds explained the role he envisioned for women writers. Trimmer evidently mistakenly thought he wanted her to present a petition, so he hastened to clarify that "it was not in my idea that a petition to Parliament should even be signed, much less be presented, by women." He continued that, "the most I could desire or expect was that they would publicly and in print declare their abhorrence of the inhuman traffic, and their wish that the measures pursuing for the abolition of it might be successful, confirmed by a small subscription annexed to their names." Reynolds ended by suggesting that Trim- 
mer and other women could also use "their private and personal influence with those who are most capable of giving effect to the benevolent attempt, whether of the nobility, clergy, or Members of Parliament." 21 There is no evidence in the minute books that the London Abolition Committee instigated or sanctioned this kind of appeal for women writers. As Trimmer's reaction suggests, women were still testing the boundaries of their participation in public life. Trimmer herself evidently declined Reynolds's request.

Yet two other women writers with Bristol ties expressed their abhorrence of the slave trade publicly and in print. Hannah More attended and taught school in Bristol, then socialised with the London Bluestockings, before becoming an Evangelical Anglican, closely associated with William Wilberforce. She published "Slavery: A Poem" in early 1788. In it, she praised "peaceful Penn" and other American Quakers for emancipating their slaves. She wrote feelingly of the impact of the slave trade on women and children, describing the "shrieking babe" and "agonizing wife;" she imagined, for example, the feelings of a family separated by the slave trade as "fibers twisting around a parent's heart / torn from their grasp, and bleeding as they part." 22 Ann Yearsley, a Bristol-born milk woman turned poet who wrote under the name Lactilla, also published an anti-slave trade poem in early 1788. Yearsley had been More's protégé, but their friendship ended over differences concerning More's investment of Yearsley's royalties. In "A Poem on the Inhumanity of the Slave Trade," Yearsley appealed to Bristol to end its participation in the trade. Like More, she evoked the violence of the trade and presented images of the women and children affected by it. For example, she bid her readers "behold" "the Maid weep o'er her inky sire," and a mother pleading for her children. ${ }^{23}$ By presenting these kinds of images of female violence and suffering, both More and Yearsley helped create "the rhetoric of sensibility" that came to characterise some abolitionist writing. ${ }^{24}$

21 Rathbone (1852), 164.

22 More (1788), lines 244, 247-248, 100.

23 Yearsley (1788), 4, 8.

24 See Carey (2005) 


\section{Anna Seward: A Personal Paradigm Shift}

Whether or not the London Abolition Committee officially advised members to appeal to women writers in the early months of its first national campaign, Josiah Wedgwood, like Richard Reynolds, did just that. Wedgwood was "intimately acquainted" with Reynolds and so perhaps knew of his request to Trimmer. ${ }^{25}$ In February 1788 Wedgwood asked Anna Seward to write a poem. He knew Seward through their mutual friends in the Lunar Society, including her Lichfield neighbour, Erasmus Darwin. ${ }^{26}$

Born in 1742, Seward moved to Lichfield as a child when her father, the Reverend Thomas Seward, became Canon of the cathedral there. In 1748, he wrote a "Female's Right to Literature", a poem linking education for girls to British liberty and national wellbeing. Well educated, strong-minded, and independent, Anna enjoyed a wide circle of literary friends, including a long friendship with Knowles, despite their differences in age and religion. During the American Revolution Seward wrote popular poems in praise of British military heroes, such as her "Elegy on Captain Cook" (1780) and a "Monody on the Death of Major Andre" (1781). In these and other poems, she celebrated British values and contributed to the development of a national culture. ${ }^{27}$ Wedgwood's request indicates that he considered her an important opinion leader.

In his letter to Seward, Wedgwood pointed out that abolition would not harm Britain's national interest. "We are already possessed of a stock of negroes sufficient for every purpose of the cultivation and trade of our plantations," he noted. "[C]onsequently $[\ldots]$ our West India commerce could not be materially injured by prohibiting further importation." Evoking a humanitarian argument, he observed that, "prohibition appears to be the only probable means of withholding the heavy hand of cruelty and oppression from those who now groan under it." He ended by stating that, "even if our commerce was likely to suffer from the abolition, I persuade myself that when the traffic comes to be discussed and fully known, there will be few advocates for the continuance of it." 28

\footnotetext{
25 Greg (1905), 2.

26 Brewer (1997), 604-612.

27 See Ferguson (1995).

28 Wedgwood (1788), Spartacus educational website.
} 
Seward replied warmly on 18 February 1788: "I am honoured and obliged by your endeavours to enlighten me on a subject so important to human virtue and human happiness" she assured Wedgwood, adding, "They have not been in vain." Describing the kind of paradigm shift concerning the slave trade that the committee aimed at producing, Seward told Wedgwood, "Your letter, and the tracts which accompanied it, have changed my ideas on the subject." Seward's reply indicates that she had answered an earlier appeal from Wedgwood less warmly. "I blush for the coldness my late letter expressed, whose subject demanded the ardour of benevolent sighs and of just indignation," she now wrote. Anxious to prove herself a person of feeling, she added, "Let me, however, do myself the justice to observe, that my heart always recoiled with horror from the miseries which I heard were inflicted on the negro slaves." Seward explained that, despite her earlier humanitarian feelings, a Lichfield resident had convinced her of pro-slavery arguments. "I have had long acquaintance with a Mr. Newton of this place, who made a huge fortune in the East, where slavery pervades every opulent establishment," she reported. ${ }^{29}$ Andrew Newton, known as "The Nabob," traded in East Indian brandy and cider and lived in a large house crammed with curiosities. ${ }^{30}$ Coupling slave trading and slaveholding, Seward said that Newton "constantly assured me that the purchase, employment, and strict discipline of the negroes were absolutely necessary to maintain our empire and our commerce in the Indies." She continued, "As constantly did he affirm that they were of a nature so sordid and insensible, as to render necessary a considerable degree of severity, and to make much lenity dangerous alike to the indulger and the indulged." Newton had assured her that "the accounts of the cruelties practiced upon the slaves by their masters were false, or at least infinitely exaggerated." He observed, that " [...] the high price and value of the subjugated inevitably preserves them from the dire effects of this imputed barbarity." Seward also recounted the gruesome experiences presented to her as an example of 'Negro' savagery by another set of personal acquaintances. Mr. Ashwell was a "former West Indian Planter, whose compassionate temper [...] [led him to give his] slaves unusual relaxation from toil and 
[...] constantly and plentifully supplied with wholesome food." Yet, "he was murdered by them in the most cruel manner." Moreover, "his nephew, then a youth of 14, [was] intentionally murdered; they ham-stringed, and cut off his left arm, and two of his fingers on his right hand, leaving him, as they thought, lifeless." Seward reported that this "last mentioned Mr. Ashwell, who lives the hapless wreck of negro cruelty, uniformly confirmed to me, for I have often conversed with him, all Mr. Newton had told me of the generally treacherous, ungrateful and bloody temper of the Negroes."

Based on these conversations, Seward explained, "I was led to consider the present efforts for their enfranchisement as fruitless and dangerous, though just and humane." She believed "that the Scriptures, which often mention slavery, bear no testimony against it as impious." Moreover, she considered "that in some countries, the subjection of beings, that form the latest link in the chain descending from human to brute animality, was an evil inevitable as war between nations has always been found in every climate." Seward admitted she had "avoided reading anything upon the subject," as a matter of national and religious pride, "flattering myself that if the abolition of a traffic so lamentable could be safely effected by our legislators, they, as Englishmen and Christians, would listen to merciful remonstrance and feel themselves impelled to abolish it." 31

Wedgwood's letter and the tracts he sent her, probably including Clarkson's essay, caused Seward to change her mind. Her experience affirmed his expectation that the facts of the slave trade would be convincing. She now told him, "They have given me indignant convictions, decided principles, and better hopes that the floodgates of this overwhelming cruelty may be let down without ruin to our national interests." Although Wedgwood persuaded Seward to support abolition, she declined to write a poem. She expressed no qualms about publicly writing on a current political topic or her abilities to do so. "You gratify me by speaking so highly of my elegies on Cooke and Andre," she told Wedgwood. She acknowledged the favourable assessments of her early poems by Thomas Bentley, Wedgwood's long-time partner and a critic for the Monthly Review. She regretted his death, because "In losing Mr. Bently [sic], my muse lost a friend and protector [who] spoke to the public in such warm 
praise of my writings." Although confident in her abilities, Seward did not have the same trust in the critics or the reading public. "I sicken at the idea of encountering the certain pains and uncertain pleasures of publication," she confided, "by committing this theme to my muse, fruitful as it is in the great nerves of poetry, pathos, and horror." As she frankly explained, "I have no confidence that her [muse's] voice would arrest the general attention. Better poetry than mine, though richly the product, is not the taste of this age." 32

To prove her point, she cited the abolitionist poem written in 1773 by John Bicknell and Thomas Day, another member of the Lunar Society. ${ }^{33}$ Seward felt this poem had not received the recognition it deserved. She opined that "Mr. Day's sublime poem, The Dying Negro, passed away without its fame, though eminently calculated to impress the public with horror of the slave-trade." Seward further told Wedgwood that, "the public hireling critics are not my friends. I have personal enemies in some of them, rendered such by my sincerity." She recounted how "because I could not stoop to flatter with praise the miserable rhymes they presented to me; and for that sin of omission to their vanity, they load my writings with imputed vulgarness, bombast, immorality and obscenity itself, as the European Magazine and English Review testify."

Seward knew about the poems of More and Yearsley, but the work of one served as a deterrent to her. "That charming writer Miss More has given the world a poem on the Slave Trade; so has her ungrateful pupil Lactilla," she told Wedgwood, "I have not yet seen either of those compositions." Wary of the critics, she continued, "I cannot prevail upon myself to give my scribbling foes new opportunity of venting their spleen by speaking to the world of the inferiority of my attempt to that of an unlettered milk woman's. So I am sure they would say, were I to write as well as Milton on the theme."

Seward closed by saying that she appreciated and carefully considered Wedgwood's request but maintained her resolve not to write a poem. "My only stimulus from without, to an attempt on this occasion, is the consciousness that you, and a few other ingenious friends, are predisposed in its favour. I confess that to be a powerful one," she told him. "During an whole hour after I received your let- 
ter, it maintained its ground ere it sank beneath the snow-drifts of opposing recollections." 34

\section{Anna Seward: Poetry, Pathos, and Horror}

Seward evidently did give serious consideration to Wedgwood's request, because, in a letter to another correspondent dated 25 April 1788, she described the poem she would have written. Affirming the increasing public interest in abolition, she sketched out a plan for "a poem on this popular subject," if she had the "time, spirits, and faith" that it would make a difference. Seward revealed to this friend what she had not told Wedgwood. She might have taken up her pen, "If I thought, which I do not, that poetry could have any influence upon our senators to induce them to espouse the cause of liberty and mercy on behalf of the negroes." In describing the poem she would have written, Seward revealed how her approach to poetic language and public discourse differed from her letter writing expressing her private opinions. In her letter to Wedgwood she made highly rational calculations of Britain's national interest and her own literary reputation, as has been seen. In this letter she used the language of social justice in equating abolition with the cause of liberty and mercy. Yet in discussing her proposed verse, she tapped into her previously self-described great nerves of poetry, pathos, and horror, using classical metaphors for heightened effect and evoking images of violence and death. Perhaps because of the information she received from Wedgwood, she now focused on the slave trade rather than on colonial slaveholding. Locating her imaginary poem in the affected continent, she said, "I would demand if Africa has no benevolent genius?" Although she had earlier recounted examples of the savage nature of Africans, she now described them as classical deities, themselves the victims of violence. "If her nymphs and her river gods are all besmeared with blood! I would make the Naiads of Niger and Gambia complain of the human gore which pollutes their waves," she imagined. "I would try if I could not rummage out some black muses, some sooty graces, to sit upon the topmost stone of a high African mountain, listening to the groans of a thousand nations." Continuing to couple classical allusions with references to 
violence, she conjured up the image of a slave ship. "I would make an execration from a sable river-god to a ship loaded with slaves, chained together in its hold," she mused. "That execration," she continued, "should be something like the Roman augur's to the legions of Crassus." The Roman general Marcus Licinius Crassus, reputedly avaricious for gold, had been cursed for rashly and unjustly invading Parthia, losing his life and 11 of his legions. With this allusion Seward presented an image of impending death and destruction, while demonstrating her knowledge of classical history, considered a traditional male preserve. Still describing the cursing of the slave ship, she referenced a popular contemporary poem about the untimely death of a young English noblewoman. The "groans and cries [of the slaves] should, at intervals," she imagined, "like the sound of the death-bell in Mason's beautiful Elegy on Lady Coventry, interrupt the execration, or be a kind of returning chorus to it." This poem by Reverend William Mason, written in 1760 and still popular, featured repeated evocations of a tolling bell as a reminder of approaching death. Yet, even in her imagination Seward maintained her national pride and faith in the humanitarianism of her country. "I would call upon the Genius of England to remember what luster the improved humanity of building hospitals etc. has cast around his civic crown," she declared. Characterising the genius of England as a male, she would "conjure him, by casting away the galling and hitherto indissoluble chain, from the naked savage, toiling for him beneath torrid suns, to open a prospect of golden days to come." 35

Seward ended her imaginary poem by paraphrasing a passage from Alexander Pope's Windsor Forest to describe the golden days to come. In his ode to peace, written in 1713, Pope foresaw a time when "conquest Cease, and Slav'ry be no more." 36 Modifying some of his words, she envisioned a place, "Where the swart negroes, 'mid their palmy groves, / Might quaff the citron juice, and woo their sable loves." The pathos and horror of Seward's proposed poem came from heightened metaphors, linking Africans with mythological figures, preyed on by violence. While her final passage evoked an emotional bond between African men and women, she did not portray the impact of the slave trade on African women and girls as had 
More and Yearsley. Instead, Seward placed herself in the company of two male poets, Pope and Mason. Nor did her proposed poem include the language of sensibility used by More and Yearsley. Yet while her proposed verse reflected authorial certainty and power, in closing her letter to her friend, she presented her personal self in a different way. She regretfully bid farewell to "my sooty muses and graces [who] kick the beam" of inspiration. Overwhelmed with domestic duties and feeling isolated and vulnerable, she wondered, "How should the solemn mourners march through the gates of my versifying region, since neither leisure, vivacity, or help are at hand to open them?" 37

\section{Mary Morris Knowles: Human Rights and Resistance}

In the early months of 1788 , as Seward considered and rejected the idea of writing an abolition poem, the London Committee succeeded in focusing public attention on the horrifying facts of the slave trade. Petitions began to flood into the House of Commons, while donations and letters of support reached the committee from all parts of the country. Joseph Woods, a member of the secret association of six and a founding member still active in the London Abolition Committee, compared "The Humanity of the People of this County" to tinder, "which has immediately struck fire from the spark of information struck upon it." 38

On 9 May 1788 William Pitt, as the leading Cabinet minister, called for the titles of the petitions requesting an investigation of the slave trade to be read over in the House of Commons. Soon afterwards, the Commons voted unanimously to consider the subject of the slave trade early in the next session. Greatly encouraged, the London Abolition Committee began preparing for the parliamentary investigation. ${ }^{39} \mathrm{By}$ then Mary Knowles was a wealthy widow living in London with her teenaged son. That June, a friend asked her to write a verse for a tobacco box, the kind of request often made to distinguished writers and public figures. Knowles answered the request with two sets of couplets: 
Tho various tints the human face adorn,

To glorious Liberty mankind are born

O may the hand which rais'd this fav'rite weed

Be loos'd in mercy and the slave be freed! 40

This seemingly simple text belies a range of argumentative strategies. The first line acknowledges racial/ethnic differences in skin colour, while the next upholds liberty as a human right. The second couplet recognises the popularity of tobacco, tacitly reminding British consumers of their links with colonial slavery, and calls for emancipation as an act of human mercy. Knowing Jane Harry Thresher and her desire to free her mother's slaves, Knowles resisted the London Committee's focus on the slave trade and spoke out publicly, if not in print, in favour of emancipation.

Although not intended for publication, her inscription for a tobacco box served a social function and would be read by others. Moreover, the verses were copied, circulated, and preserved in Quaker archives. In these ways, the couplets reached a variety of readers, typifying the kind of social authorship which Ezell describes in her study of women's literary history and textual agency. ${ }^{41}$ On 12 August 1788 the London Abolition Committee issued another public report announcing the formation of local committees, the presentation of more than 100 petitions to the House of Commons, and the receipt of $£_{2,760}$ in subscriptions. "Mrs. Mary Knowles" is named in the published list, giving the healthy sum of five guineas. ${ }^{42}$ As Richard Reynolds had earlier suggested to Sarah Trimmer, Knowles expressed her wish for the success of abolition by making a publicly acknowledged contribution to the London Abolition Committee.

\section{Conclusion}

As nationally recognised opinion leaders, Mary Morris Knowles and Anna Seward reflected and contributed to the national paradigm shift concerning abolition during this key period in the first public campaign. Between the two of them, they used all six of the parameters identified by the Innsbruck team; racial/ethnic, economic, reli- 
gious, humanitarian, natural rights, and national arguments. As female writers they participated in the full range of the emerging national discourse that eventually resulted in the abolition of the slave trade.

In 1788 Knowles and Seward supported abolition in all three ways that Reynolds outlined in his appeal to Trimmer. Seward experienced and then furthered the paradigm shift by declaring her abhorrence of the slave trade in her letters. Knowles used her private influence in composing an anti-slavery verse for the tobacco box when requested by a friend. She also publicly contributed to the abolition campaign. In these ways, Knowles and Seward expanded the space for women to participate in the public campaign to end the British slave trade. In the following years, women poets like Helen Maria Williams and Anna Laetitia Barbauld continued to write verses in support of abolition. Women played an even more active role in early nineteenth-century efforts to end slavery throughout the British Empire. Yet Seward and Knowles also embodied significant differences in their lives and abolitionist writings. They differed in age, religion, locale, and marital status. Although they both spoke out in favour of abolition as strong women, they employed different parameters and used different language. Seward used national interest and humanitarianism in her arguments, while Knowles defended human rights and argued for abolishing slavery. Moreover, while Seward evoked images of violence, Knowles, as a Quaker and a pacifist, did not.

In the 1790s the French Revolution divided Seward and Knowles just as it deeply divided Britain and the supporters of abolition. The different argumentative strategies used by the two women reveal a major fault line between them and among the national coalition supporting abolition, the differences between humanitarianism and human rights. Arguments in favour of human rights were silenced in Britain as a result of the French Revolution, and, for a while, the public cry for abolition fell silent, too. By the early 1800s, many abolitionists patched together their philosophical differences and again united against the slave trade. By then, however, Knowles and Seward were no longer friends. Knowles died in February 1807, one month before Parliament voted to end the British slave trade. Nevertheless, four of her husband's Quaker colleagues on the in- 
formal association of six lived to see the success of the London Abolition Committee. ${ }^{43}$

Seward lived another two years, meticulously revising the letters she selected from among her voluminous correspondence for posthumous publication. She included both letters cited here, her reply to the request from Wedgwood and the one describing the abolition poem she might have written, in the six volumes of her correspondence published in 1811. In this way, after her death, Seward publicly and in print spoke out in favour of abolition. Her letters were widely read and reviewed by both males and females, and she would not have been surprised that critics then and now both greatly appreciate and vigorously attack her views. Tory literary critic John Wilson Croker savaged some of her statements, for example, while Poet Laureate Robert Southey quoted her description of her intended poem in his collection of the works of the popular poet William Cowper, who also advocated abolition. ${ }^{44}$

Taken together and taken seriously, these two women broaden the idea of which writers and what argumentative strategies contributed to the early success of abolition in Great Britain. Their life stories and literary texts offer insights into the formation of their abolition views and the paradigm shift in national views concerning slavery and the slave trade. Their experiences suggest the range of female response to abolition and demonstrate the need for further research concerning women's roles in the antislavery paradigm shift in the late eighteenth and early nineteenth centuries.

\section{Works Cited}

Barbour, Hugh (1979): "William Penn, Model of Protest Liberalism," in: Church History 48 (2), 156-73.

Boswell, James (1791): The Life of Samuel Johnson. London: Charles Dilly.

Brewer, John (1997): The Pleasures of the Imagination. New York: Farrar, Straus, Giroux.

British Library, "List of the Society Instituted in 1787, For the Purpose of Effecting the Abolition of the Slave Trade, London, August 12, 1788." 
Burnard, Trevor/Morgan, Kenneth (2001): "The Dynamics of the Slave Market and Slave Purchasing Patterns in Jamaica, 1655-1788," in: The William and Mary Quarterly, Third Series 58 (1), 205-38.

Carey, Brycchan (2005): British Abolitionism and the Rhetoric of Sensibility: Writing, Sentiment, and Slavery, 1760-1807. London: Palgrave Macmillan.

Clarkson, Thomas (1808): The History of the Rise, Progress and Accomplishment of the Abolition of the African Slave Trade. 2 vols. London: Frank Cass.

Croker, John Wilson (1831): The Life of Samuel Johnson. 5 vols. London: John Murray.

Ezell, Margaret (1993): Writing Women's Literary History. Baltimore: Johns Hopkins University Press.

Ezell, Margaret/O'Keefe, Katherine O'Brien (1994): Cultural Artifacts and the Production of Meaning. Ann Arbor: University of Michigan Press.

Ezell, Margaret (1999): Social Authorship and the Advent of Print. Baltimore: Johns Hopkins University Press.

Ferguson, Moira (1995): Eighteenth-Century Women Poets: Nation, Class and Gender. Syracuse: State University of New York Press.

Green, Joseph J. (1913): "Jenny Harry, later Thresher (c. 1756-1784)," in: Friends Quarterly Examiner (10th Month): 559-82.

Green, Joseph J. (1914): "Jenny Harry, later Thresher (c. 1756-1784 (concluded)," in: Friends Quarterly Examiner (1st Month), 43-64.

Greg, Eustace, ed. (1905): Reynolds, Rathbone Diaries and Letters, 1753-1859. Privately printed.

Hopkins, Mary Alden (1952): Dr. Johnson's Lichfield. New York: Hastings House.

Hunt, N.C. (1961): Two Early Political Associations. Oxford: Clarendon Press.

Jennings, Judith (1997): The Business of Abolishing the British Slave Trade, 17831807. London: Frank Cass.

Jennings, Judith (2006): Gender, Religion, and Radicalism in the, Gender in the Long Eighteenth Century. Aldershot: Ashgate.

Knowles, Mary (1784): Gentleman's Magazine, 716.

Knowles, Mary (1791): Gentleman's Magazine, 500-502.

More, Hannah (1788): Slavery: A Poem. London: T. Cadell, online at: http:// www.brycchancarey.com/slavery/morepoems.html (accessed on 21.2. 2009).

National Archives, Colonial Office Records, 139/319.

New York Historical Society, Gilder-Lerman Collection 1794, \#37.

Pope, Alexander (1736): Windsor-Forest. Edited by Jack Lynch based on Pope's Works, online at: http://andromeda.rutgers.edu/ jlynch/Texts/ windsor.html (accessed on 21.2.2009).

Rathbone, Hannah Mary (1852): Letters of Richard Reynolds with a Memoir of His Life. London: Charles Gilpin.

Religious Society of Friends Library, London, Matthews Manuscripts, Letters from Joseph Woods to William Matthews. 
130 Religion, Liberty, Violence, and Resistance

Seward, Anna (1811): Letters of Anna Seward. 6 vols. Edinburgh: Archibald Constable.

Smith, Nigel, ed. (1998): George Fox: The Journal. London: Penguin Books.

Southey, Robert (1844): The Works of William Comper. 8 vols. London: H.G. Bohn.

Spartacus Educational (2008): “Josiah Wedgwood," online at: http://www. spartacus.schoolnet.co.ik/REWedgwood.htm (accessed on 21.10.2008).

Uglow, Jenny (2005): The Lunar Men. New York: Farrar, Straus, and Giroux. Yearsley, Anne (1788): A Poem on the Inhumanity of the Slave Trade. London: G. G. J. and J. Robinson, online at: http://www.brycchancarey.com/slavery/ yearsley1.html (accessed on 21.2.2009). 
The Act of Remembering the "Dis-Remembered": Sorting Out the Memorialisation of Liverpool and the Transatlantic Slave Trade

Angela M. Leonard

A recent survey of the research on slavers' logbooks, slave traders account books, voyage database sets, captain's personal records, and Royal Naval vessel accounts of controlling the maritime trafficking of the African slave trade after passage of the International Abolition Bill in 1807 reveals that there is a gross imbalance in our scholarly study of memorialisation and representation of Liverpool's involvement in the Transatlantic Slave Trade. While many library shelves have begun to sag due to the volume of books, and journals that are being published on the transatlantic trade and now on the experiences of the enslaved, there are still too few close analyses of letterbooks, diaries, account books, and slave ship captains' log books. It seems that for every fifty works on the trans-Atlantic trade (this includes articles, pamphlets, anthologised essays, and monographs), there are few critical studies on the menagerie of characters, events, routes, trades, cargo, travails, etc. that fill the pages of a slave captain's log. Much of what has been done is quantitative and beneficial to economic historians who are still obsessively calculating the profitability of the slave trade. ${ }^{1}$

1 See Darity, Jr. (1995). The recent publication by Stephanie E. Smallwood, Saltwater Slaves: A Middle Passage from Africa to American Diaspora (Cambridge: Harvard University Press, 2007), while not focused narrowly on the Liverpool involvement in the trade, is a seminal attempt to turn the focus of the scholarship onto the Middle Passage as a human tragedy of lives lost, broken, maimed, and forgotten. 
When we do not approach the slaver's log ideologically, we miss what can be celebrated. With an inverted perspective, or what Richard Jackson would describe as "disremembering," - i.e. remembering the forgotten or rejected particulars of past experiences - the details radically change in meaning and interpretation; the reader of the $\log$ is paused to be impressed by the layers of memories that the details in the $\log$ nuance. ${ }^{2}$ While much of the research today about the enslaved focuses on 'The Middle Passage' and blacks who constitute this early African Atlantic holocaust, the slave ship captain's logs are remarkable accounts, inadvertently, of resistance and survival, and of the desire to be free. Yet they are also documents that link the early voices of the Transatlantic Slave Trade to contemporary, modern concerns, consequently resulting in the proliferation of writings in recent studies of the Atlantic World, post-traumatic slavery syndrome, as well as global justice, and reparation rights.

Yet, few of these studies address the very collectivity of memory that the $\log$ books expose. While a re-examination of slavers' log books reaffirms their obvious quantitative value, such re-reading also causes us to confront more than one-concurrent Middle Passage, as well as a history of dis-remembering, or 'dis-memory.' This history of dis-memory has been historically avoided and justified based on the academic historian's conventional insularity of detachment and disassociation from the human dynamic inscribed in primary texts. By dis-memory, I mean the deliberate choice to not engage beyond the uncontested facts. It seems appropriate, though, that we talk about these concurrent memories as well as the art (and act) of disremembering - in light of the recent commemoration of the $200^{\text {th }}$ anniversary of Britain's abolition of the slave trade. It would seem that to continue to objectify this realm of the history of Great Britain's port cities is to shut out the very fact that even contemporary events reveal how nation, class, and sexuality are mediated by as well as trumped by race right here in Liverpool. For the contemporary analyst, even a cursory re-reading of a few log books results in the re-editing of one's memorialisation agenda. Ergo, this essay will concentrate on some of the strategies contained in slavers' logs that signify both modes of remembering as well as structures of dis-memory.

2 Jackson (1990), 134, 141. Jackson's use of the concept “disremembered" stimulated my reread of prior work on accounts of transatlantic slave trade voyages. 
Slavers' logs and other personal papers associated with the Transatlantic Trade of enslaved Africans unveil multiple 'Middle Passages'. In fact, constituted in this African-Atlantic metaphor are at least five historically inscribed memories of the transatlantic experience. Often noticed first are accounts that memorialise the Transatlantic Trade and expansion of European imperialism. Second, are the logs with transcribed comments: (a) by and about the members of the slavers' crew; and/or (b) by slave ship captains; and/or (c) dialogues between European and African traders, thereby indicating the direct personal contact. Third, are records which provide illustrations of landscapes, of which many no longer exist such as $15^{\text {th }}$ to $18^{\text {th }}$-century descriptions of the African coast. The fourth Middle Passage stream recognises the 'scatteration' of peoples - Europeans, Asians and Africans within the Old and New Atlantic World basin. And a fifth stream of this metaphor of memories is that of dis-memory - i.e. a spiritual journey of death, denial, and discovery. This last stream also accounts for the conventional view of historicising the African dead. This essay briefly points out aspects of these distinguishable, yet overlapping metaphoric streams of the Middle Passage.

The first type of account of the Middle Passage topically identified above - the one more often memorialised and lectured about references trade negotiations, insurance fluctuations, itemisation of imported and exported goods exchanged, onboard and off-shore supplies, and a variety of other technical acquisitions deemed necessary to purchase and physically secure 'cargo'. For example, P. E. Hair examined an account book found among the Sir Edward Hasell Family Papers at Dalemain in Cumbria, England. In it were details of the trading practices of two eighteenth-century Liverpool merchants, Christopher Hasell, 1760-1773, and his father-in-law, John Goad, 1750-1772. While these personal records only provide a limited glimpse of the economic costs of voyages of the Dobson, its inclusion of the "Purchase of Slaves on board the Dobson in Old Calabar in $1769 " 3$ categorised and distinguished the historic value of the account book's relation to Liverpool's involvement in the Transatlantic Slave Trade. This first stream of tabulated 'Middle Passage' memories, however, is generally impersonal and objective. Mackenzie- 
Grieve's introduction to specific artefacts of the British imperial trade with Africa is in keeping with this perspective and tone. He writes,

[...] fully-rigged ships, the brigs and snows [as they] sailed down the Mersey bound for the Guinea coast. Their holds filled with bales: blue bafts, Osnaburg checks, patten chintz and romalls from Manchester; iron and copper bars; anchors of raisin wine and brandy; muskets, powder and flints; to pay for the negroes of Whydah, Accra and Bonny. Africa, the Middle Passage, the West Indies and they sailed back up the river laden with rum and sugar, goods and slaves profitably sold; fat profits for the owners, bonuses for the captains. ${ }^{4}$

This first kind of Middle Passage drama is also concerned with insurers of ships and investors in the trade. It bears witness to the fluctuations in insurance rates at various locations, all being subject to the historical and environmental whims of the time. While "slaves were $[. .$.$] sold readily, [\ldots]$ one profitable voyage might $[. .$.$] have to$ compensate for two or three disastrous ones." Moreover, as Mackenzie-Grieve notes, "profits could not be assured till the risks and hazards of the Middle Passage between Guinea and the West Indies were behind them." Concern about profits was also triggered by spikes in insurance. Pre-Revolution insurance rates in Jamaica were quite high in 1760. In fact, they had risen "to twelve guineas per cent." Because of this increase "143 Liverpool ships lost in four years - one-third of them slave ships - the whole Carolina indigo crop of ' 57 taken by the French; French privateers everywhere." 5

For students of the Transatlantic Slave Trade, the delineation of details given by Mackenzie-Grieve and other scholars of this subject are quite rich because it shows a meshing of the African dead, the captains' failures, the African chiefs' commodity, the routes taken, the variability and relativity of the buyer and seller's market, and the crew's travails. What cannot be understated is that these tabulations implicate the basic difficulty in fixing precise totals to any incident associated with the transatlantic slave trade. In his vintage study on this subject, William O. Blake assembled data retrieved from now familiar slave captains in the trade. He recorded,

4 Mackenzie-Grieve (1941), 6.

5 Mackenzie-Grieve (1941), 30, 9. 
With respect to the mortality of slaves in the passage, Mr. Falconbridge says, that in three voyages he purchased 1,100 and lost 191; Trotter, in one voyage, about 600, and lost about 70; Millar, in one voyage, 490, and lost 180; Ellison, in three voyages, where he recollects the mortality, bought 895, and lost 356 [...] the slaves had the small-pox.

Mr. Morley says that in four voyages he purchased about 1,325, and lost about 313. Mr. Towne, in two voyages, 630, and lost 115. Mr. Claxton, in one voyage, 250 , and lost 138 . In this voyage, he says, the[y] were so straightened for provisions, that if they had been ten more days at sea, they must either have eaten the slaves that died, or have made the living slaves walk the plank, a term used among Guinea captains for making the slaves throw themselves overboard [...]. Captain Hall, in two voyages, purchased 550, and lost $110 .^{6}$

Although the diversity of primary sources that contain figures about the Middle Passage has swelled today, the desire to ascertain the actual number of captured Africans who were disembarked in North American and Caribbean markets is still difficult to ascertain. The growing availability and access to voyage files and slave logbooks documents combed carefully by principally economic historians speaks to numerous attempts to make plausible estimates of the mortality and survival rate of persons in the Middle Passage. ${ }^{7}$

Estimates of loss and survival of actual persons literally en route constantly shifts with the recovery and identification of new evidence, but these figures increase substantially when the general topic becomes simply mortality and the Middle Passage. In this sense, we then account for those who died prior to embarkation, before they passed through 'the door of no return', that is to say, those who died on the coast in 'slave pens'. What do we make of those who died probably due to emotional breakdowns? How do we/can we ascertain the numbers of persons lost because of the psychological weight of the experience of natal alienation, genealogical isolation or "social

6 Blake (1840), 134-135.

7 Collaboration by David Eltis, Stephen Behrendt, David Richardson, and on the publication of the W. E. B. Du Bois Institute's The Trans-Atlantic Slave Trade: A Database on CDROM (Cambridge Univ. Press, 1999) now provides scholars with greater samples of slave ship voyages to better ascertain approximate mortality figures as well as the decline in the numbers. 
death," to use Orlando Patterson's expression. ${ }^{8}$ Even during peace times, voyages experienced a loss of enslaved cargo and seamen off shore and during the transatlantic voyage, who were "ravaged by fever or dysentery. In the dirty, over-crowded ships, epidemics were impossible to check, and on his arrival in the West Indies a captain might find his cargo depleted by twenty, thirty, forty, even fifty per cent." "9

Too often the crew of slave ships is glossed over in scholarship. Yet, their experiences constitute a second pool of memories of the Middle Passage. Not only are there multiple streams of Middle Passage memories, but each categorical group of participants produce a splay of layered histories. The economic destitution of their presence aboard these slavers maintains the connection for some to the home-based experiences suffered by segments of the population from which they may have originated. Mackenzie-Grieve writes,

The men who haunted the dock-side taverns were often escaped jail-birds, criminals evading detention, or 'gentlemen's sons of desperate character and abandoned habits.' [...] In the British ports there were many innkeepers who found co-operation with the slave captains profitable. It was easy to induce men to drink themselves so heavily into debt that they accepted service in a Guinea-man as the only alternative to imprisonment. ${ }^{10}$

The crew's composition and travails at sea should not be underrepresented; especially in respect of how they and their regimented assignments factor into the overall profit of the voyage. Not the least are first-hand accounts of how sailors view their experiences, as observable in Joseph Pinder's A Diary \& Abstract of a Journal on a Voyage from Liverpool to Maranham, Demeerary, and back to London; in the ship Crown, Jos. Pinder Master. Commencing May 12, 1826 and Ending [19 October 1826].11 However, slave ship logbooks also reveal that the crews' chores were occasionally performed by the enslaved. In Logs on board H. M. S. Agamemnon, the Count du Nord and the Mampookata, the first mention of "neagroes" is as of Wednesday, 22 October 1783. They were "Employed shifting the Provisions in the Men's (?)

8 Patterson (1982), 1-7, 10-13.

9 Mackenzie-Grieve (1941), 11.

10 Mackenzie-Grieve (1941), 35.

11 Pinder (1826), 18-21. 
room \& to make room for the Carpenters to fix the platforms for the Neagroes [...]." 12 This assemblage of documents also includes receipts of wages paid to Captain Dixon from James Penny for his employ aboard the Mampookata. ${ }^{13}$

The vessels of the Royal Navy, in particular the West African squadron, are as important in the study of the Middle Passage as privately owned vessels and their crew. The military history of soldiers who confronted great odds in their efforts against slavers, who often not only out-distanced them, but also out-suited them in artillery, and out-numbered them in size of ships' crew, are the memories that are derivable from logs of navy ships. Such is the case of the Firefly Sloop. The Log of the Firefly Sloop clearly suggests the intention of the British crown to abolish the Transatlantic Slave Trade and presumably the institution of slavery itself. Between 1850 and 1852, the Log records the following ports-of-call: Cape Sierra Leone, Jamestown, St. Helena, Ambrig, Congo, Cape Lagos, Loango. In addition to the logbook listing several "articles of war," it provides notations of daily housekeeping duties and ritualistic activities aboard the vessel; "September 23 employed [...] for passage to Coast of Africa." After the record recounts divine service on Sundays, entries begin to notate weekly chores:

employed cleaning the ship [...] washed clothes; [...] employed caulking; [...] employed fitting [...] rigging; [...] employed as requisite; $[\ldots]$ employed receiving and stowing away provisions; [...] employed preparing to go out of Basin; [...] employed completing coal and water; [...] received stores an a parcel for African Squadron (Thursday, October 3, 1850); [...] people variously employed; $[\ldots]$ receiving mail for [...] Chief (November 7, 1850); [...] employed painting ship. ${ }^{14}$

12 Logs on board H. M. S. Agamemnon (1782-1798), 387 MD 62/1.This volume 387 MD 62/1, in which a number of documents were enfolded, contains of logs and/or 'Remarks' apparently kept by Thomas Dixon while sailing with a ship of the line H.M.S. Agamemnon and on the slave ships Count du nord and Mampookata in the period 1782-1786.

13 May 11, 1785, £.314, Grenada; April 25, $1788 f .4$.[?]s for wages, from July 4, 1787 to April 12, 1788;, 9 months and 5 days; May27,1788 for wages on board the Madampookata from 4 June 1787 to 12 April 1788,, March 24, 1793 for fifteen month, $£ 146.7 \mathrm{~s}$, Grenada; June 6, 1798 for twelve months, $£^{204.7 p 7}$, Martinique; June 6, 1798, Martinique, fifteen

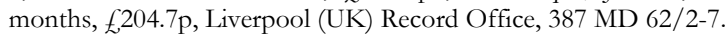

14 Log Book of Firefly Sloop (1850-1852), vol. 1; Liverpool (UK) Records Office, 387. MD 33. 
The details infer the training and discipline of the enlisted and disclose a high level of attention to ship maintenance.

In the case of seamen, primary documents evince their duties ranged from overseeing the captured enslaved (and Christianised) Africans ${ }^{15}$ to capturing African slavers, as well as warding off attack from pirates. In Thomas Gibson's Journal of a Voyage from Liverpool to Monte Video and Buenos Ayres in 1837-38, some sailors aboard the Schooner mention their prior employment aboard slavers which have now turned into pirate ships. "Captain Roe tonight particularly enhanced the pleasure of our thoughts and conversation tonight by telling us of the chance of our [...] line falling in with 1 of these fast sailing schooners formerly in the slave trade, but now since that has been abolished turned pirates." 16 He returns to this topic later in the journal:

The Capt. [a]gain frightening us about pirates! Tho' the slave trade (i.e. the [...] sorting of fresh slaves,) is now prohibited by all nations, they are still largely smuggled into the Havanna, and the schooners and brigs (being necessarily fully armed and mannered to resist our ([[...] fleet of brig of war), generally plunder what vessels fall in their way! 17

This second Middle Passage stream, however, moves easily beyond neutral terms of quantity to commentary about members of the crew; hence, the narrative of the Middle Passage invariably yields over to another inescapable human dimension in this world of trade. In his account of the Liverpool slaver at Bonny Falconbridge confirms the dominant perspective found in Middle Passage re-tellings, that it was an engagement where thoughts of profit were always trumped, or they rather obliterated displays of humanity. Attention given to the physical size and health of the captured, before and during the voyage, was a non-issue, except in accessing the dimension and capacity of the slave ship's hull to accommodate purchased Africans. Falconbridge wrote,

By purchasing so great a number, the slaves were so crowded that they were even obliged to lie one upon another. This occa-

\footnotetext{
15 See discussion of the Yoruba Mission of the Church Missionary Society in western Nigeria, Ward.

16 Gibson (1837-38), 920 MD 399/1, 34.

17 Gibson (1837-38), 920 MD 399/1, 92-93
} 
sioned such mortality among them that [...] nearly one half of them died before the ship arrived in the West Indies [...].

The place allotted to the sick negroes is under the half-deck, where they lie on the bare planks. By this means, those who are emaciated frequently have their skin, and even their flesh, entirely rubbed off, by the motion of the ship, from the prominent parts of the shoulders, elbows and hips, so as to render the bones in those parts quite bare. And some of them, by constantly lying in the blood and mucus, that had flowed from those afflicted with the flux, and which, as before observed, is generally so violent as to prevent their being kept clean, have their flesh much sooner rubbed off, than those who have only to contend with the mere friction of the ship [...]. Few, indeed, are able to withstand the fatal effects of it. ${ }^{18}$

Compounding the gripping recounts of meshed Middle Passage perspectives are the strategies used by captains to sell the 'rejected' cargo. When re-read to remember, we learn more about the under-belly of the trade - the deception, the medical experimentation, the antiSemitism, especially of accusations of Jews re-selling/re-exporting 'refuse' slaves (a claim that has recently been largely discredited ${ }^{19}-$ and of the variety of contagions and other debilitating afflictions that were endured. We learn of the emaciated and dying who were cast overboard, as well as those who were disposed because of food shortages, tonnage of overweight vessel, or for fraudulent insurance claims. With regards to food stuffs, there is a counter-discourse that is activated questioning the adequacy of food supplies and to what extent death is attributable to starvation. Notwithstanding, these narratives introduce a new discourse of ideological terms that vividly and conceptually describe individuals involved in the trade, such as 'slave-hawkers', 'soul-drivers', sale by 'scramble', and 'walking the plank'. This vocabulary becomes associated with Middle Passage experiences.

Some of the slave ship trade documents are a cross-pollination of private-commercial and national suppression of activity during the transatlantic slave trade. Such is the case in Jos. Pinder's Diary and Abstract. Indeed, Pinder's record is equally valuable to the study of the Middle Passage because it contains elements that would consti- 
tute the third stream of memory of especial importance to environmental historians of this period. Along with an implicit discussion of the cargo aboard The Crown (as noted by an explicit reference to 'cotton') there are references to multiple vessels, some of which are of a military kind, controlling the trade between colonial possessions and Europe. Ergo, the second Middle Passage stream moves easily beyond quantification and commentary by and about crew members into the third stream of ports of call (i.e. Island of Madeira, Canary Islands, the Leeward islands, from Martinique to Surinam - and all in between) offering descriptions of the sea and landscapes, wildlife and other creatures of nature, such as birds, dolphins, and butterflies. Similarly, Thomas Gibson, throughout his Journal of a Voyage from Liverpool to Monte Video and Buenos Ayres, in 1837-38, engages in discussion about marine life (varied fish species, salmon, porpoises, etc.) and "big white and black birds," insects, and trade winds. ${ }^{20}$ Gibson's Journal is a literary palette created by the author's comments about the colour changes in sky and sea as his ship travels from Liverpool into the tropics and beyond. ${ }^{21}$

Even more significant for the purposes of this paper is Joseph Pinder's Diary and Abstract which mentions instances referring to enslaved Africans. For example, visual accounts of landmass, as mentioned above, are related to the living quarters of the enslaved. Joseph Pinder describes the "splendour of Maranham island." Yet, in the back of the estate homes, there are "Huts for the Negroes, belonging [to] the establishments" which are associated with some Jewish islanders. ${ }^{22}$ The mentioning of Negroes and Jews within the same contexts leads into the fourth memory metaphorised by the term 'Middle Passage', that being of the scatteration of peoples, cultures, and the construction of new racial identities about which Ira Berlin writes in his "From Creole to African." In Gibson's Journal of a Voyage from Liverpool to Monte Video and Buenos Ayres, in 1837-38, one learns of the coupling of seamen with natives. He mentions that some shipmen, even captains marry once they reach new lands. ${ }^{23}$ Pinder's Diary, however, contains the author's daily observations as he walks through local streets and witnesses a diverse population of

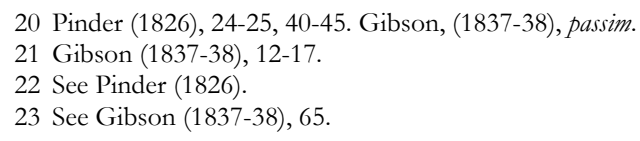


enchained individuals: “[...] criminals, Negroes, Indians, Mulatoos, Mustees, Parabaus, and other [...]." The following day the previous entry continues with Pinder's extended observation of the punishment inflicted on these individuals. In fact, the entry of Tuesday, 19 June 1826, mentions the flogging of two black boys. Pinder's Diary, therefore, extends the Middle Passage beyond the sea to activities on land. For in Letter 1, Pinder mentions churches 'Negroes' were allowed to attend and one of the ministers who in his sermons alludes to the problem of slavery and each individual's right of liberty. In addition to the New World people that were being imported, Pinder spends time reflecting about the Indians of 'Demeeray', and their relation to the Negroes. ${ }^{24}$

The fifth Middle Passage stream is rarely 'remembered' in traditional quantification studies or conventional research on this topic, ergo, another reason for this essay. On the other hand, 're-memory' is taken up by scholars deeply rooted in African religion or anthropological understandings of various African ethnicities' rituals and beliefs and by cultural analysts who contend that the history of human activity is also inscribed in the silence of details - i.e. facts, places, past events, natural and environmental sites, and also in the deceased and their sites of memory. By examining this fifth stream of some voyage accounts, we push ourselves to question what constitutes the dis-memory of activity above and below deck, on and off shore. This process involves re-reading not only accounts of embarkation and loading of cargo and exchanging exports, of disembarkation selling cargo and exchanging exports, but also of returning home to Liverpool in connection with remittances and insurance claims. This fifth perspective links the top deck to the deck below; it links the long period of waiting on the West African Coast to the agitation that is manifested on board ship. Yet more precisely, dismemory entails the desires of the enslaved who want to be free resisting their capture. The Middle Passage of mutinies, rebellions, and insurrections that turned the ship upside down and backside up again, as we sense the reality of people who are determined either to hold fast to their dignity, or the crew who simply want to stay alive. This fifth reading of the slavers' log involves all the elements of the

24 See Pinder (1826). Tuesday, June 13, 1826, Wednesday, June 14, 1826 and Thursday, June 15, 1826, 45-47; Tuesday, June 19, 1826, 58. For full coverage, see Pinder's extensive discussion of blacks, negroes, and slaves, 47-56; 68-80, 91-92. 
voyage, all of the willing and unwilling participants on the voyage, and all of the repercussions after the voyage. It is the aspect of the Transatlantic Trade that I would argue deserves to be memorialised the most because it involves, fundamentally, that universal which no one can escape from - the "way of death" (a phrase borrowed from Joseph Miller's Way of Death: Merchant Capitalism and the Angolan Slave Trade, 1730-1830).

The fifth Middle Passage stream, then, as dis-memory also involves an inverted reading of the role of the slave ship captain. For example, in one sense, the personal, though business record of a slaver's log makes it an 'intimate history' of the captain's work. Indeed, the delineation of negotiations, illnesses, ship break-downs, financial losses and navigational mis-calculations sometimes approaches the recreation of Melville's mythical realism of voyages at sea. At the same time, the log lists an arsenal of equipment that is associated with the maintenance of the colonial system of involuntary labour: chains, shackles, neck harnesses, iron rings, ropes, whips, guns, etc. These instruments of violence, as words, give voice to and pictorialise that which even the slave captors might prefer to 'disremember.' That is to say, the militaristic articles on board and the regular arming of the crew denote fear. The crew feared the unknown and potential revenge and insurrections of blacks. This state of war also evinced their own confusion - similar to today's child soldiers - about signing up for a dangerous job at sea that also totally robbed them of their humanity in the process of its performance. The very fact that insurrections did occur indicates the volatility of the trade.

The language of violence, of war, of imperialism, evidenced by the instruments of harm, pain, destruction, and death express what is known but not articulated, what Richard Jackson refers to as "slave crossing motifs." What are these 'slave-crossing motifs"? They "include blacks in chains, the stench, blood, hatred [of the enslaved by the crew and vice-versa], and the ever-present [white] sharks [...] waiting to devour black bodies who leaped or were thrown overboard, and [the] madness" 25 caused by diseases, by the inhumanness of it all, from the washing down of the hull by the crew to the raping of the women and the claustrophobia and entrapment in the slave 
deck. Jackson notes, "Log books and ship diaries are the source of much of these words, written by uneasy crew, who fear rebellious blacks' crazy laughter and other manifestations beyond their comprehension." 26 These seemingly neutral terms, therefore, fuel the imagination and evoke the descriptive aspects of each perception of the Middle Passage.

Indeed, the quantity or abundance of the tools of the trade, the tools of containment, constitute the very materiality capable of overloading a reader's sensibility. How can we not smell the stench, how can we not hear the painful cries, how can we not feel the vulnerability due to the foamy invisible mist rising from the sea? Is it not at this point that we nearly begin to enter the minds of all of those on this treacherous journey of death? The very weight of the descriptive data - literally and figurative - can produce the affect of 'shock and awe', for the very quantity denotes the difficulty involved, the degree of de-sensitisation necessary in trying to purposefully dis-remember the events, the human dimension and experiences, associated with the Middle Passage.

This dis-remembering is even facilitated by the names of the Liverpool slave ships. Consider the names of the vessels owned by the Liverpool merchant family of Tarletons - the Jenny, and the Catherine; the Edgar of Liverpool, commanded by Captain Ambrose Lace; the Duke of York, commanded by Captain Beaven of Liverpool; or Captain Robert Bostock, master of the Bloom; or Captain "Bully" Roberts of the Thomas, as well as of the Little Ben, The Bess, The Jemmy, and the Kite - the latter four which he hired out. And there was also Thomas Whittle, who was captain of Thomas Leyland's the Lottery; and the Guinea-man, the Will, and the Mary owned by the Aspinalls, a family that owed much of its wealth to Hugh Crow, a Liverpool captain. ${ }^{27}$ Hidden behind these overwhelmingly masculine names of the vessels are not only those who heavily invested in them and activities that occurred during transport, but

26 Jackson (1990), 134. For an extended study of "key features of shipboard slave revolts," "variations in the incidence of revolts by African region of embarkation of slaves," and the "impact of slave ship resistance" on insurance rates, see Behrendt./Eltis/Richardson (2001). Behrendt, et al based their findings on the Du Bois Transatlantic Slave Trade Database Set, that is to say " 388 cases of slaves rising in revolt against ship's crew, the first recorded instance being in 1654 and the last in 1865, though 92.5 per cent of all revolts occurred between 1698 and 1807," 455. Also see Richardson, (2001).

27 Mackenzie-Grieve (1941), 20, Chapter 4. 
also more imperatively, activities that occurred when these ships were docked at Bonny, or Old Calabar as previously noted. Notable among shore-side violence is the massacre aboard the Duke of York and the Edgar of over "three hundred of the men of Old Town" Calabar. Ignited by British traders, this slaughter pitted New Town chiefs against the independent trading posture assumed by the headmen and the chief of Old Town, Calabar. It has been argued that this kind of inter-African ethnic violence, as recorded in the slavers' $\log$, justified the actions of anti-abolitionists as principled. For from their perspective, according to Mackenzie-Grieve, "they really came to believe that they were saving the negroes of Africa from the savage barbarity of their chiefs." 28

Slave ship captains' logs are serials. Their materiality embodies memories about and by people who are unaware that they live at a great historical moment, but who are cognizant of each day spent aboard ship as one wrought with challenges, some more terrifying than others. Re-reading these ship logs requires us to stretch imaginatively to envision the unfolding of narrated lives. They inscribe a series of monologues or duets in which each elemental entry (e.g. person, cargo, weather, ship equipment, etc.) supplies detail that adds to our reconstructed memory of a journey in medias res. The logs reveal a world where the captured interact with the free, where either free or enslaved represent millions who died during the voyage, where each person is potentially the ghost of the dead. These logs, therefore, serve as witnesses for all the 'disremembered' and as reminders of the collectivity of Middle Passage experiences. They connect past and present, living and dead, fact and fiction, memory and imagination, myth and reality, the conscious and the repressed past. Re-reading them, therefore, catapults us into the realm of myth-making. For when viewed as serialised paeans to the disremembered, to the dead, the slave ship captain's log leaps beyond chronological time. The captain himself, as recorder of the log, is to some degree a "myth custodian," 29 since his notations, inadvertently, sketch a history of the African as captive on the Western Coast of Africa through the Middle Passage to the African as sold cargo in

28 Sparks (2004): Prologue and Chapter 1; also see Lovejoy/Richardson (2001) and Mackenzie-Grieve (1941), 55-60.

29 Jackson (1990) applies this descriptor to Manuel Zapata Olivella, as "one who traces black history from the mythological beginnings through the Middle Passage forward," (141). 
the Americas; traces the Liverpool vessel from Merseyside to Old Calabar, El Mina, Bonny and back to Liverpool's port. What most of these logs generally neglect to share with us, however, is a fuller dimension of the Captain's reality of slave trading he is confronted with regardless of whether he makes a full return journey home. For while his journal and logs contain the ingredients of myth-making, many of his personal letters paint a very human reality of a man suffering under extreme pressure of two kinds - one, because of his inability to reimburse the creditors, and two, because of his inability to collect payment on loans given to fellow tradesmen. ${ }^{30}$

In conclusion, these logs have intrinsic value and harbour the interests of multiple constituencies. One of the questions to consider is how focussing on the 'collectivity' of constituencies, of voiced, silenced, and repressed memories might bring us to an understanding of the multiplicity of human and topical associations, the overlapping of personal memory, national memory, and collective (group) memory, of the inter-diasporic and intra-diasporic crossing of geographic and residential boundaries. What might this inclusive analysis yield? The very idea of such a paradigm of memories speaks to the intrinsic 'collectivity' of memory and exemplifies how complicated and difficult the trans-Atlantic trade was from port to port: the losses of cargo while at sea; the historical interludes when supply exceeded demand; the silenced scenes that bear witness to planters confronted with monetary shortfalls (on the one hand, due to the shrinkage of export sales of slave-made or -produced goods, and, on the other, due to their own limited funds resulting in an inability to purchase or further increase the number of their enslaved labourers); the disruptive impact of local and global political events such as the American Revolution and the Haitian Revolution that temporarily impeded transatlantic trade; and lastly, the general precariousness of climatic conditions which invariably graphed the thin line between success and failure in this transatlantic marketplace.

By focusing on conceptual streams of the Middle Passage experience as a metaphor, the main issue I have presented and stressed here is the need to focus on the intrinsic collectivity of those who should be represented in any memorialisation of Liverpool's involvement in the Transatlantic Slave Trade. This 'collective memory' 
is significant given the mixed diasporic identity of many blacks and whites living in Liverpool today. An interrogation of slavers' logbooks and slave ship captains' journals and account books quickly unveils a multitude of identities that were formed during the height of Liverpool's Transatlantic African enterprise and the external forces that shaped them.

By 'unpacking' records, in particular of voyages, associated with the transatlantic slave trade and zooming in on several conceptual streams of the Middle Passage, a cache of questions emerges - concerning national, cultural, and racial identities of those who have historically resided in Liverpool - that indicates the multi-layeredness of these documents and highlights their potential use to engage in a multicultural discussion at a national level. To be clear, a onedimensional examination of slave ship captains' record books does hint at a kind of academic avoidance, one not unlike to Liverpool merchants who saw nothing (and tuned out) any of the tawdry aspects of the cargo and the voyages. "That was the captains' business. The filth, the agony, the degradation transformed into gratifying symmetrical rows of figures on clean white paper. Negroes were naked and black, they spoke an unintelligible tongue." 31 If we avoid the visual goulash of race in Liverpool, or Bristol, or London, or Birmingham, or Plymouth, or a number of locations in Europe and North America that grew and prospered because of their entrenched engagement in the transatlantic sale of captured Africans, are we not in effect making a statement about the politics of memorialisation, about what constitutes memorialisation, about whose memories are valued, and about the cultural politics of race in these cities?

\section{Works Cited}

Anstey, Roger/Hair, P.E.H., eds. (1976): Liverpool, the African Slave Trade, and Abolition. Liverpool: Liverpool University Press.

Behrendt, Stephen D./Eltis, David/Richardson, David (2001): “The Costs of Coercion: African Agency in the Pre-Modern Atlantic World," in: The Economic History Review 54 (3 August), 454-76.

Berlin, Ira (1980): "Time, Space, and the Evolution of Afro-American Society on British Mainland North America," in: American Historical Review 85 (1 February), 44-78. 
Berlin, Ira (1996): "From Creole to African: Atlantic Creoles and the Origins of African-American Society in Mainland North America," in: William and Mary Quarterly 53 (2), 251-88.

Blake, William O. (1840): The History of Slavery and the Slave Trade, Ancient and Modern. Columbus, $\mathrm{OH}$ : H. Miller.

Buxton, Thomas Fowell (1840): The African Slave Trade, and Its Remedy. London: John Murray.

Darity, William Jr. (1995): "The Numbers Game and the Profitability of the British Trade in Slaves," in: Journal of Economic History 45 (3), 693-703.

Eltis, David/Behrendt, Stephen D./Richardson, David/Klein, Herbert S. (1999): The Trans-Atlantic Slave Trade: A Database on CD-ROM. Cambridge and New York: Cambridge University Press.

Faber, Eli (1998): Jews, Slaves, and the Slave Trade: Setting the Record Straight. New York: New York University Press.

Falconbridge, Alexander (1788): An Account of the Slave Trade on the Coast of Africa. London: J. Phillips, online at: http://books.google.com (accessed on 19.10.2008).

Firefly Sloop: Log Book of a Voyage to West Africa, 1850-1852. Liverpool (UK) Records Office, 387. MD 33, Old No. Eq 927.

Gibson, Thomas: Journal of a Voyage from Liverpool to Monte Video and Buenos Ayres, in 1837-38. Liverpool (UK) Records Office, 920 MD 399/1.

Hair, P.E.H. (1990): “Antera Duke of Old Calabar-A Little More about an African Entrepreneur," in: History in Africa 17, 359-65.

Inikori, J. E. (2002): Africans and the Industrial Revolution in England: A Study in International Trade and Economic Development. Cambridge: Cambridge University Press.

Jackson, Richard (1990): "Remembering the 'Disremembered': Modern Black Writers and Slavery in Latin America," in: Callaloo 13(1), 131-44.

Logs on board H. M. S. Agamemnon, the Count du Nord and the Mampookata, with related papers. 1 vol., 9 docs., 1782-1798, 1848, 1981, Liverpool (UK) Record Office, 387 MD 62.

Lovejoy, Paul/Richardson, David (2001): "Letters of Old Calabar Trade, 1760-89," in: Carretta, Vincent/Gould, Philip, eds.: Genius in Bondage: Literature of the Early Black Atlantic. Lexington: The University Press of Kentucky, 89-115.

Mackenzie-Grieve, Averil (1941): The Last Years of the English Slave Trade: Liverpool 1750-1807. London: Putnam \& Company, Ltd.

Miller, Joseph (1988): Way of Death: Merchant Capitalism and the Angolan Slave Trade, 1730-1830. Madison: University of Wisconsin Press.

Morgan, Kenneth (2008): "Liverpool's Dominance in the British Slave Trade, 1749-1807," in: Richardson, David/Tibbles, Anthony/Schwartz, Suzanne, eds.: Liverpool and Transatlantic Slavery. Liverpool: Liverpool University Press, 14-42. 
148 The Act of Remembering the "Dis-Remembered"

Patterson, Orlando (1982): Slavery and Social Death: A Comparative Study. Cambridge: Harvard University Press.

Pinder, Joseph: A Diary \& Abstract of a Journal on a Voyage from Liverpool to Maranham, Demeerary, and back to London; in the ship Crown, Jos. Pinder Master. Commencing May 12, 1826 and Ending [19 October 1826], by Joseph Pinder. Liverpool (UK) Records Office, 387 MD 37.

Richardson, David (January 2001): "Shipboard Revolts, African Authority, and the Atlantic Slave Trade," The William and Mary Quarterly, online at: http://historycooperative.press.uiuc.edu/cgi-bin/justtop.cgi?act= justtop\&url=http:/ /www.historycooperative.org/journals/wm/58.1/ richardson.html (accessed on 26.10.2008).

Shannon, Alexander Harvey (1907): Racial Integrity and Other Features of the Negro Problem. Nashville, TN: M.E. Church, South.

Smallwood, Stephanie E. (2007): Saltwater Slaves: A Middle Passage from Africa to American Diaspora. Cambridge: Harvard University Press.

Sparks, Randy J. (2004): The Two Princes of Calabar: An Eighteenth-century Atlantic Odyssey. Cambridge: Harvard University Press.

Ward, W. E. F. (1969): The Royal Navy and the Slavers: The Suppression of the Atlantic Slave Trade. London: George Allen \& Unwin. 


\section{All in the Family: Mixed-Race Jamaicans and their Imperial Networks in the Eighteenth Century}

Daniel Livesay

In the eighteenth-century British Caribbean, interracial relationships were not only common, they dominated society. With very few white women in the islands, white men often preyed upon enslaved women and women of colour, as well as frequently entered into quasi-normative relationships with them. This produced a substantial population of colour, particularly in the Empire's largest island, Jamaica. These relationships were far from hidden, and, in fact, friends and family across the Atlantic were often well aware of their existence. In addition, white Jamaicans frequently socialised with mixedrace islanders, due to personal connections with their parents, and frequently took care of them when those parents left the West Indies. At the same time, absentees in Britain regularly dealt with the complicated matter of manumitting mixed-race children on their estates, at the request of a white father's pleas. Jamaican people of colour, then, occupied a prominent and visible place in the social and commercial networks of the early British Empire. This paper argues that the personal connections between Jamaica's mixed-race population and whites on both sides of the Atlantic helped the island's people of colour actively resist the structural and cultural impediments placed against them in the colony.

White society in the West Indies was a very insular community. Jamaica, Britain's largest Caribbean island in the eighteenth century, both geographically and demographically, never held more than 30,000 whites prior to its first census in 1844. Most likely the popu- 
lation hovered steadily between 15-20,000 whites before emancipation. ${ }^{1}$ With an enslaved population over ten times that size, Jamaica's white society attempted to close ranks in order to stabilise their precarious hold over the island. Strict laws against the enslaved and free people of colour sought to keep whites firmly in control of governance and finances, if not segregate the communities altogether. ${ }^{2}$ The violence of the slave system, combined with this highly restrictive legal code, effectively contained colonial power in white hands. At the same time, personal connections, often rooted back in Britain, kept Jamaica's white populace intimate, if not closely knit. As with any colonial outpost, letters of introduction were a prerequisite for doing business in Jamaica. This was particularly true for the many Scots who came to the island in the eighteenth century. Describing his experiences in Jamaica's major cities of Kingston, Spanish Town and Montego Bay, J. B. Moreton noted, "I never knew a raw lad from that country [Scotland], who had not a letter of recommendation to his Excellency, or to some Mac or other; upon the delivery of which, he was taken notice of, and immediately put into some business." 3 These connections, whether founded in clanship, relation, or trade, bound white society more closely together as a hedge against Jamaica's much more numerous population of colour.

White Jamaicans privileged these transatlantic connections, owing in part to the itinerancy and instability of their island society. Not only did absenteeism produce social lacuna, but heavy mortality and meagre family migration to the island eliminated any chance for a stable, self-reproducing white community from developing. Significant gender imbalances between whites, as well as a pronounced culture of sexual violence against women of colour, also worked against a stabilised group, serving instead to enlarge Jamaica's mixed-race population, thereby undermining the island's idealised racial binary. ${ }^{4}$ One of Jamaica's richest whites, Simon Taylor, passed his concerns

1 Based on population estimates by Heuman (1981), Table 1, 7.

2 Colonial legislation became increasingly more severe toward free people of colour as the eighteenth-century wore on. In 1733, the group lost the right to vote, and in 1761, the Jamaican Assembly limited the amount that an illegitimate child of colour could inherit up to $f_{2000}$ island currency.

3 Moreton (1790), 64.

4 Verene Shepherd estimates that well over 60 percent of Jamaican whites were male in 1780. Shepherd (1999), 21. For a discussion of the cultural element of miscegenation in the West Indies that goes beyond simple demographic realities, see Garraway (2005). 
about this phenomenon on to his friend George Hibbert: "Our White Population is dayly nay hourly decreasing [...] [Jamaica] will either fall into the hands of Negroes or Mulattoes or the Inhabitants will give it up to any other European Powers who will protect their lives." 5 Not surprisingly, Taylor was unmarried himself, and had sired a number of mixed-race children. ${ }^{6}$ However, his position in the island's elite made him acutely aware of the demographic imbalance between blacks and whites. The Jamaican Assembly had tried for years to augment the island's white population through the so-called 'deficiency acts' which required landowners to ship in more white residents under threat of stiff fines. ${ }^{7}$ Those acts, however, had done virtually nothing to stabilise the community; most planters treated them as a tax, making little effort to bring in more whites. Indeed, Jamaica's white population stayed small, transient, and non-selfsustaining throughout the entirety of the eighteenth century. Interpersonal connections amongst whites may have been essential and highly-prized, but they were in constant need of refurbishment and repair.

This combination of a small but well-acquainted white community, alongside an ever-present culture of miscegenation, resulted in a society well aware of its own indiscretions. White Jamaicans not only recognised that the island's mixed-race population was growing, they knew many of the mixed-race islanders personally. Family ties and genealogy did not dissolve simply because racial barriers had been transgressed. One of the best sources by which to investigate these relationships is Thomas Thistlewood's journal from his years in Jamaica between 1750 and 1786. Thistlewood's extensive diaries stand out for their bald depictions of sexual predation on enslaved women; a reflection of the overwhelming degree of sexual violence against enslaved and free coloured women in Jamaica. Scholars have tended to focus on the nearly 4000 sexual acts which Thistlewood logged

5 Simon Taylor to George Hibbert, 31 October 1798, ICS 120, Letter Book B, No. 30, Simon Taylor Papers.

6 Simon Taylor's will speaks to his large, bi-racial family, as does the journal of Lady Maria Nugent, who reacted quite unfavourably to her discovery of these children. See Simon Taylor Papers, ICS 120 II B, No. 36, 27 January 1763, ICS; Nugent (1966), 68.

7 Hall (1975), 5-19. 
over thirty years in his journal. ${ }^{8}$ Even if these records stand out for their singularity amongst West-Indian accounts, they represent only one portion of Thistlewood's diary. In fact, Thistlewood made extensive comment on island life, as well as the community to which he belonged. His knowledge of the sexual dalliances of his neighbours is just as revealing as the chronicles of his own behaviour.

Throughout his journal, Thomas Thistlewood displayed a sustained fascination with appearance and visible signs of African heritage. Having migrated from Lincolnshire, in northern England, Thistlewood rose through the ranks of Jamaican society until he purchased his own plantation in 1767. Immediately after his arrival Thistlewood took an interest in the island's racial dynamics. He noted of a future employer, "Mr. Dorrill has the Whitest Mulatto Son I ever Saw, very fair and has long hair." Such phenotypic peculiarities of inter-racial unions became commonplace in Thistlewood's early diary entries after coming to Jamaica. In his first months he recorded one curiosity: "In the Evening Walked to Capt. Cornish's [...] he keeps a Genteel Mulatto girl, tho Some Say She is from White parents of both Sides, Which I can Scarce believe."10 Thistlewood's incredulity reveals an inherent problem in the racial categorisation in which Jamaicans engaged. Jamaica's exceedingly large population of colour, which included a growing number of individuals who bore no physical evidence of African ancestry, propelled the Assembly to provide a biological escape-route from legal repression for residents phenotypically white, yet still descended from Africans. The island's Assembly allowed individuals, more than three generations removed from an African ancestor, to become legally white; the only British island in the West Indies to provide such a path to 'whiteness'. ${ }^{11}$ This effort was intended to maintain the façade of a free/white, restricted/black society in the face of a vastly more complex racial landscape. Racial categorisation, then, proved important, not only at

8 Burnard (2004), 156; Hall (1989). Both scholars emphasise Thistlewood's sexual activities, although Burnard also gives a thorough account of Thistlewood's meteorological and intellectual interests as well.

9 Thomas Thistlewood Papers, Reel 1, No. 2 (1750), f. 283.

10 Thomas Thistlewood Papers, Reel 1, No. 1 (1750), Microfilm, f. 149.

11 Anyone more than three generations removed from an African ancestor was legally white: Jamaica, Great Britain. Laws, Statutes, etc. 21 Geo. II xv. 20. 
a cultural level, but also at a legal one. In this way, continued miscegenation served to enfranchise further Jamaica's populace of African ancestry. Despite the islanders' best efforts, however, 'scientific' attempts to categorise individuals never proved as reliable as expected, and phenotype could often exert undue influence on one's racial identity and standing. Jamaica's population of colour could use their appearance, therefore, as leverage against the island's legal oppression. Thistlewood's suspicion of Capt. Cornish's mistress, then, may have been as much a concern about fraud as it was of proper social decorum.

Observations on the sexual lives of his neighbours led Thistlewood to speculate about the lineage of children amongst nearby enslaved women. Rumours swirled in Jamaican society about the bloodlines of individuals on the various estates. Whites regularly interested themselves in the actions of a man toward his mistress of colour, and vice versa. In 1765, Thistlewood recorded in his journal some gossip that he heard from Mr. J. Winch about a Major Clarke who attacked his mistress. Thistlewood noted that the Major disfigured "his Mulattoe Sweetheart, in Jealousy because he said a Negroe Should never use those Eyes she had. She having brought a Child rather too dark." 12 The complexion of a child could be an obvious sign of alternate partners, and this news did not escape Thistlewood's circle. The extensive amount of predation on enslaved women often produced children by white men who had little or no connection to the estates on which the women resided. Thistlewood himself, having not purchased his own plantation until 1767, regularly attacked women from nearby estates; frequently women whom he barely knew. This chaotic sexuality easily fostered intensive jealousy, particularly when it involved a white resident's favourite sexual partner. Thistlewood, himself, maintained a protracted and meaningful relationship with an enslaved woman named Phibbah, who lived on the estate of John Cope. With some degree of bitterness, Thistlewood wrote of Phibbah having "deliver'd of a Child, dead, a fine Boy (a Mulatto): In the Forenoon had him buried - Suspect Mr. J[ohn] C[ope] Junr. [...] [with] seemingly a Resemblance to" the child. ${ }^{13}$ Thistlewood and his fellow Jamaicans held vigilant attention 
over the bodies of their communities' enslaved women. Just as their bodies and sexuality were treated as something of a communal asset, so too was the history of their sexual activities a matter of public record. ${ }^{14}$

Such interest in these sexual relations familiarised white Jamaicans with the mixed-race children who slowly began to populate the island. In Thistlewood's case, he almost universally noted the father of a mixed-race individual, if he knew him whenever he mentioned interacting with one. After buying a bookcase from "a Mullatoe girl, nam'd Jenny," Thistlewood concluded, "She is free, and a Daughter of old Ned Stevens." 15 Thistlewood's other references to mixed-race individuals also give descriptions of their family origins. When "a Mulatto Boy Nam'd Billy" was hired out to John Cope, Thistlewood described him as a, "Brother to Peggy by the Mother's Side, \& Captain Marshall was said to have been his Father." 16 It is difficult to understand the purpose of these addenda, other than to maintain supervision of the white fathers, or to inform his perceptions of the children they sired. Thistlewood also reported on the crimes of two mixed-race Jamaicans, taking care to reference their white parents. When a "Mulatto Girl" named Rachael stole money from a Mr. Mason, Thistlewood added that Rachael was the daughter of John Foot and his black mistress. Similarly, he indicated that a mixed-race man, alleged to have killed two runaway slaves, was the son of Layton Smith. ${ }^{17}$ The near universality of Thistlewood's lineal descriptions seems to indicate intensive interest in the background of his neighbourhood's mixed-race population. With such suspicion of people of colour in Jamaica - particularly regarding their loyalty to whites - Thistlewood may have worked so diligently in order to discern between those whom he thought to be trustworthy, and those whom he suspected of rebelliousness. Whatever the reason, his interest demonstrates the detailed understanding he had of the local mixed-race community and the family connections at their foundation.

\footnotetext{
14 This seems to conform to the arguments about European fascination with African female sexuality and reproduction as discussed in Morgan (2004).

15 Thomas Thistlewood Papers, Reel 1, No. 2 (1750), f. 354.

16 Thomas Thistlewood Papers, Reel 3, No. 8 (1757), f. 109.

17 Thomas Thistlewood Papers, Reel 6, No. 20 (1769) f. 337; Reel 7, No. 23 (1772), f. 203.
} 
While Thistlewood scrutinised the population of colour around him, he also interacted with them quite regularly, often by virtue of the very family connections that he continually studied. When white friends came to work or to visit, they often brought their mixed-race children. On one occasion, a Mr. Mordiner came to work at Egypt estate, where Thistlewood acted as overseer, and "brought his Mulatto Son Tom with him." Tom stayed on the estate for one week, as did his brother, Jimmy, at another date. ${ }^{18}$ Social visits were also common and Thistlewood had no qualms fraternising with his friends' children of colour. One evening in 1762, he was visited by a party of friends, which included the mulatto son of a Mr. Senior, who presented Thistlewood with one of the ducks that they had shot earlier in the day on a hunting expedition. On another occasion, he gambled with "one Mr. Kudd a Mulatto, \& Kudd's Son" who ended up with some of that night's winnings. ${ }^{19}$ These instances reveal a society not nearly as segregated as the colonial government would have wished. With so many white men siring children of colour, and with many of those men taking care of their offspring, social interactions between whites and people of colour were frequent. As with his other observations on this mixed-race population, Thistlewood was diligent in noting the kinship of those with whom he socialised. The family connections of these people of colour were vital to their elevated standing in the white community. It would have been impossible for whites to ignore their presence, and if they showed a degree of toleration, it was most likely founded upon the family background of these individuals.

The connections between whites and people of colour, sealed through familial and personal relationships, became more formalised and vital when planters left the island for Britain. Fears about the colonial climate as well as aspirations to establish themselves in the British aristocracy pushed many whites to quit Jamaica once they had acquired a decent fortune. ${ }^{20}$ Many left their colonial families in the colonies, often at tender ages. Some, however, ensured that their friends back in Jamaica watched over their mixed-race children until they reached maturity. John Tailyour, for instance, depended upon a number of friends to watch after his former mistress of colour, 
Polly, and their children, after he returned to Scotland in 1792. Although he would eventually have the children sent to Britain as well, Tailyour asked his two former clerks in Kingston, David Dick and Tailyour's soon-to-be brother-in-law John McCall, to take care of his family in Jamaica. John McCall not only reported back the birth of Tailyour's last child, Catherine, but also discussed the normal day-today issues that faced the family: the children's sore throats, Polly's toothaches, and the general misbehaviour of Tailyour's young toddler. ${ }^{21}$ Others joined in to pass along family news to Tailyour as well. His good friend, James Renny, and both his former business partners, Peter Ballantine and James Fairlie, each congratulated Tailyour on the birth of Catherine. Visiting the family after Catherine's arrival, Fairlie wrote encouragingly, "Polly \& the Children are well, Little Kate is a very fine Child \& I think will be fairer than John [one of Tailyour's sons]." 22 Fairlie's comment on Catherine's complexion speaks to the importance that white Jamaicans placed on their children's phenotype. This was particularly true in the case of colonists such as Tailyour who planned to have their children eventually join them in Britain, where it was hoped they could easily assimilate into European society.

The role of Tailyour's friends and business associates in supervising his colonial family proved vitally important to their well-being in the absence of a white patriarch in Jamaican society. Polly had been born enslaved, as had each of her children, and she had little to depend upon besides the financial assistance of her erstwhile Jamaican partner. Both David Dick and John McCall acted as mediators between Polly and Tailyour. McCall passed messages between the two, including Polly's hope to have Catherine sent to Britain quickly, as Polly was "not capable of bringing her up as she would wish." ${ }^{3}$ Polly also pushed McCall to lobby Tailyour for a new home for the family, and McCall worked alongside Ballantine and Fairlie to settle her in a better house. ${ }^{24}$ Whether through Polly's insistence or white benevolence, Tailyour's Jamaican network also helped her to manage

21 John McCall to John Tailyour, 14 October 1792 - 27 December 1794, Tailyour Papers.

22 Peter Ballantine to John Tailyour, 14 October 1792; James Renny to John Tailyour, 5 October 1792; James Fairlie to John Tailyour, 16 September 1792, 25 December 1792, Tailyour Papers.

23 John McCall to John Tailyour, 12 May 1793, Tailyour Papers.

24 John McCall to John Tailyour, 14 July 1793 to 2 March 1794, Tailyour Papers. 
her finances. David Dick supervised the hiring out of the slaves that Tailyour had left Polly. He was able to rent out four of her slaves, which he believed would "enable her to live comfortably hereafter." 25 Dick's help may have been inspired by empathy with Tailyour's colonial family, as he later had a child of his own by a free woman of colour named Margaret Halbert. ${ }^{26}$ Tailyour, for his part, seems to have washed his hands of Polly once he left for Scotland, focusing instead on the upbringing of the children. After another volley of letters from John McCall about Polly's finances, Tailyour replied, with some degree of annoyance: "I think the negroes \& house I left her (for her life) is quite sufficient to keep her very comfortably if well managed \& I leave it entirely to you to do with the whole what you see best." 27 Tailyour's Jamaican family, then, depended heavily upon the patriarch's business and social networks for their livelihood on the island. The personal connections that they developed with Tailyour's ties lasted for years, and put them into positions of power to negotiate for better lives within Jamaica's oppressive society.

Active lobbying on the part of mixed-race Jamaicans was not the only way for them to benefit from European relatives. White Jamaicans also intervened on the behalf of people of colour whom they felt had either been neglected by their fathers, or were in an unstable social position. After his death, the family of George Barclay had some difficulty in settling his estate. Nearly thirty years after first travelling to Jamaica, Barclay returned to Britain, still a bachelor, and married his Scottish housekeeper. The alliance was scandalous to the planter's family, coming only a few months before his death. As the family sorted out his finances, his brother James Barclay, who still resided in Jamaica, made an appeal for part of the inheritance. Hoping to pass a message to the George's executor, James wrote: "You know my Brother has three Children here: Sukie \& two Lads. I think 'tis hard they should have been forgot in his Will \& something should be done for them. I wish you would mention them to Mr. Gordon [the executor] \& confer with him about the matter." 28 James

25 David Dick to John Tailyour, 23 October 1797, Tailyour Papers.

26 Baptism Register, St. Andrew Parish, 23 February 1805, 1B/11/8/1/1a.

27 John Tailyour to John McCall, 25 November 1807, Tailyour Papers.

28 James Barclay to John Thompson, 23 May 1757, MS 1160/5/9, Gordons of Buthlaw and Cairness Estate and Family Papers. 
Barclay's connection to his mixed-race niece and nephews was strong enough that he lobbied on their behalf. Family ties stayed strong, as long as one remained in Jamaica.

Others relatives and friends were only vaguely aware of mixedrace kin in the colonies. Living in Jamaica, John Wedderburn helped Glaswegian George Oliphant Kinloch to find a school for his three mixed-race nieces and one nephew. George's brother, John Kinloch, sired the children. While it is uncertain what happened to him, George had assumed the affairs of the children from across the Atlantic by 1774 . John Wedderburn not only arranged for their schooling, but also offered Kinloch advice about the most proper course for their lives once they completed their educations. ${ }^{29}$ Family and business networks on both sides of the Atlantic, then, were crucial in maintaining the livelihood of mixed-race Jamaicans in the colonies. For those so helped, they were not hidden from view, but rather took a visible, if not precarious, place within the networks of their fathers.

The advancement of mixed-race individuals in Jamaica depended upon both of these active and passive forms of resistance through their white relatives. Women of colour who became sexual partners of white men regularly used their relationships as tools for their own social advancement and especially the benefit of their children. ${ }^{30}$ As we have seen with John Tailyour's lover, Polly, such lobbying often required persistence in the face of a reluctant benefactor. Her position in Tailyour's Jamaican social circle, however, allowed her greater access and a more visible presence to his familial patronage, even with the Atlantic as a divide. Conversely, Jamaicans of colour were so embedded in white commercial and social networks that white colonists often felt the urge to lobby on their behalf when problems arose. The firm presence of mixed-race Jamaicans within white society, both colonial and metropolitan, permitted more frequent and more successful acts of resistance against an extraordinarily powerful system of racial oppression.

While kinship networks may have formed an unsurprising connection between white and mixed-race individuals in the Empire, the normal business of colonial enterprise brought many other Britons

29 John Wedderburn to George Oliphant Kinloch, 22 December 1774, GD 1/8/35, Grange Estate Papers, f.115.

30 Bush (1990), 115-116. 
into regular contact with these children of colour. Children born in Jamaica, as with the rest of the British West Indies, inherited their legal statuses of freedom from their mothers. If a white man sired any offspring with an enslaved woman, then he had to pay manumission fees, as well as compensation to the owner, in order to have his children freed. This meant that plantations throughout Jamaica regularly engaged in the business of manumitting and substituting slaves for anxious fathers. These transactions required the consent of absentees, or the heirs of a West-Indian estate, back in Britain, who by virtue of their business dealings became fully cognizant of the sexual lives of the Jamaican colonists. Sometimes the correspondence was quite direct, and acted upon quickly. While in Liverpool, Thomas Mosley wrote back to Jamaica after William Littlewood had hoped to secure the freedom of his mistress, Phibbah, and their two children. Mosley asked that Littlewood pay the estate $f_{1} 100$ rather than substitute three slaves for his family, as there were "slaves enough upon the plantation without having any more." 31 This seems to have finalised the matter on Mosley's estate. At other times, the process could take prolonged periods of time due to the slow speed of communication across the Atlantic, as well as normal delays in negotiation. On the Hermitage plantation, in southwest Jamaica, attorney William Adlam had difficulty in resolving one such manumission. Writing back to John Wemyss to explain the delay in concluding the matter, he commented, "I have not seen Mr. Bonthorn concerning the purchase of his Mulatto Daughter." Adlam hoped that Bonthorn could substitute slaves for his child, as the estate needed more labourers, but he added, "I once mentioned this circumstance to him but he did not seem inclined to do it." Nine months later, the issue still had not been resolved, and Adlam continued to complain of Bonthorn's delays. ${ }^{32}$

More frequently, manumissions involved family connections, either to the correspondent in Britain or to the agents in Jamaica. Although not professionally tied to James Stothert's colonial estate, Isaac Grant became intimately involved with Stothert's mixed-race daughter. Stothert had since returned to Scotland, and Grant ap-

31 Thomas Mosley to Sarah Smith, 17 January 1755, MS 230, f. 71, National Library of Jamaica.

32 William Adlam to John Wemyss, 1 February 1820 to 7 November 1820, MS 250, Hermitage Plantation Estate Book, National Library of Jamaica. 
pealed to the absentee for his daughter's freedom. Hoping to negotiate a settlement with his mistresses' father in Scotland, Grant wrote, "I took the liberty of writing you some time ago respecting your daughter Rebecca, at present my housekeeper. I have now only to observe in case you have not already given her her freedom that I'll give you a good \& picked new negro [for her]." ${ }^{33}$ Grant's appeal presents an interesting case of reintroducing a white father to his presumably abandoned child. Many white men assaulted the enslaved women on their plantations with little or no consideration of the children they might sire. Though Stothert had taken no pains to free his daughter before leaving for Scotland, Grant's letter demonstrates the degree to which these children could easily reappear in their fathers' lives. Other family connections also undergirded these manumissions. When Thomas Hamilton wrote to a Mrs. Dickson regarding "a Mulatto Child belonging to your Estate named Peggy Young," he noted that the girl's white father had not provided an adequate replacement for her liberty. Hamilton promised to correct the deficiency himself: "as her Father was a relation of mine I am willing to put a new Negroe boy or girl of from 14 to 16 Years of Age on your Estate as an equivalent for her." 34 Thus, family connections could maintain some level of protection for mixed-race children. For Mrs. Dickson, who undoubtedly inherited the Jamaican estate from a relative, these letters served as a lesson in the complexities of island society.

Lessons on the dynamics of Jamaican life also came in the form of prevarications by white fathers to emancipate their children of colour. British absentees concerned at the financial impact of mixedrace children on their estates could receive a rude schooling on island conduct. This was true even for those who had direct experience with Jamaica. Charles Angus, having retired to Liverpool, depended upon his brother William to take care of his Jamaican affairs. He told William about several rogue slaves on his estate, including "a Female Quartroon ${ }^{35}$ [living] with a Gentleman in Spanish Town [...] she and two others are the Children of a Mr. Taaff." Charles did not wish to have an enslaved woman to whom he had a legal claim co-

33 Isaac Grant to James Stothert, 10 June 1799, James Stothert Letters.

34 Thomas Hamilton to Mrs. Dickson, 3 February 1808, MS 2008, National Library of Jamaica.

35 'Quadroon': a child two generations removed from an African ancestor. 
habiting with a man in Spanish Town if he were not to receive any kind of compensation for her: "how dare they keep our slaves without either paying for their services or discharging the Colonial Taxes." Having no interest in the domestic arrangements of these women, Charles implored his brother to have them sold in order to increase his estate's efficiency. William, however, struggled to enforce his brother's actions. When neither the man cohabiting with the enslaved woman, nor her father, agreed to pay for her, Charles commanded William, "if their Parents will not buy them, as they said they would, [to] sell them to those who will buy and Pay their Value." The demands continued for years, as William was unable to get the men to compensate his brother. Five years after his first instructions on the matter, Charles ridiculed William, "they must think you a fine easy fellow, not to exercise that Power for my Interest, but sacrifice it for theirs who have done the Property all the injury they could." 36 The intransigence of Mr. Taaff and his mixed-race daughter's lover provided enough social pressure to disarm William and effectively block Charles from trading his slaves as he wished. As benefactors, the lovers of enslaved women could, under such circumstances, successfully combat the power of plantation owners. These men's social weight in the community could prevent their mixed-race families from becoming separated, effectively rendering their lovers free, in all but name.

The management of family issues could also result in open pronouncements against Jamaican social practice. Anna Eliza Elletson had inherited the Jamaica estate of her late husband, Governor Roger Hope Elletson, upon his death in 1775. She returned to England where she married the Duke of Buckingham and Chandos, but she kept abreast of the running of Hope Estate. At least two men who worked at Hope had sired mixed-race children, and both made appeals to the Duchess on the subject of their offspring. After manumitting the child of one of them, the estate's distiller's, Lady Chandos expressed the desire to her island attorney, "that [the] Black Lady will not engross too much of his attention from his business." ${ }^{37}$ As with Charles Angus, the islanders' sexual interactions

36 Charles Angus to William Angus, 10 April 1802; 3 March 1804; 17 December 1805; 12 February 1807, 7/352/3, f. 21; f. 45; 65; f. 82, Charles Angus Letter Book.

37 Anna Eliza to Messrs. Pool and East, 17 January 1776, MS 29, Roger Hope Elletson Letter Book, National Library of Jamaica. 
created economic problems, but Lady Chandos's correspondence also reveals a more generalized disgust of involvement with an enslaved woman.

Absentees, like the Duchess of Chandos, could be particularly harsh, especially when their attorneys in Jamaica had less experience than them in the colonies. When a Mr. Cameron asked to buy the title to his enslaved mistress and their four children from one Jamaican estate, the estate's attorney, Adam Fergusson, pushed as hard as he could to unite the family. Hugh Hamilton, the estate's absentee owner, refused the request, demanding replacement slaves rather than money. Fergusson wrote back: "Now though I own it is not desirable to part with Slaves from an Estate underpeopled, I confess I should be much inclined to gratify a Man with respect to bis own children and their Mother. [...] But in this I shall acquiesce in what you and the other Gentlemen [...] shall determine." 38 Fergusson's deference to Hamilton reveals the degree to which absentees could remain involved in estate management. Hamilton and other Jamaica grandees in Britain maintained a constant link with the West Indies, which kept them fully aware of the mixed-race community, and they still exercised a degree of control in the well being of that population.

Such ties between whites on either side of the Atlantic and Jamaica's people of colour remained strong through these intimate familial bonds. Active lobbying on the part of Jamaican people of colour through their white kin could help secure a more advanced place within island society. At the same time, white Jamaicans with personal connections to the mixed-race community could also argue on their behalf. Even those across the ocean became deeply familiar with individuals of colour due to the familial bonds that tied together their commercial interests in the colonies. The ubiquitous occurrence of miscegenation that took place on Jamaican estates put whites firmly within the social networks of the island's growing population of colour. Jamaica's mixed-race community, then, was not an entirely ostracised and segregated group within the colony. The personal and familial connections between whites and people of colour allowed many mixed-race islanders to circumvent the colonial impediments to their social and economic well-being. These circumventions could become legally codified by the Jamaican Assembly, 
which granted increasing numbers of petitions from mixed-race Jamaicans for advanced legal rights due to their financial and family circumstances. ${ }^{39}$ This familial patronage, then, allowed for the development of a third 'racial class' between Europeans and Africans in Jamaica, unlike the more functionally pure racial dyad that existed in North America. It also allowed for certain mixed-race Jamaicans to stand well outside of a perceived undifferentiated mass of coloured inhabitants, which whites believed was growing too large. Whether it came in the form of official decrees from the colonial assembly or through casual public ties, social advancement for non-whites depended upon family background. Drawing on the complex family connections that tied the island together was the most dependable and most successful method for Jamaicans of colour to escape racial persecution in their colonial environment.

The connections amongst white Jamaicans, as well as their links to Britain, were crucial to popular perceptions of the West Indies' mixed-race community. Those in Jamaica were able to distinguish different subsets of mixed-race groups in the island: enslaved people of colour, poor people of colour who were free, and those whom they knew - through their fathers - and whom they could judge on a more personal basis. As the mixed-race population rapidly increased over the eighteenth century, greater numbers of free coloureds emerged who were the children of two parents of colour and who had less of a connection with the island's whites. ${ }^{40}$ The family and personal connections between the white and mixed-race community, then, grew more distant as the century came to a close. This distancing coincided with the advent of the abolitionist movement as well as the Revolution in St. Domingue, which were seen by supporters of enslavement as twin threats to the plantation system. This directed more attention toward the mixed-race community and their allegiance to the colony. Scholars themselves have struggled to understand where the loyalties of that mixed-race population stood at

39 From 1733-1802, over six hundred Jamaicans of colour petitioned the colonial Assembly for privileged rights, which allowed them the same rights as whites, with the exception of voting, holding office, or serving on juries against white defendants. Well over half of those who petitioned, did so in the last two decades of the eighteenth century. The Colonial Office records at the National Archives of England, Kew, hold all of the rulings on these petitions (see Colonial Office Records 139/13-51).

40 Heuman (1981) Table 1, 7. Heuman gives a rough estimate that the free population of colour in Jamaica climbed from 4,000 in 1770 to nearly 30,000 in 1825. 
the time. If confusion arises, it is because West-Indian people of colour never belonged to a homogenous group in the eighteenth century. ${ }^{41}$ The expanding diversity of their class, upbringing, and connection to the white community increasingly made mixed-race individuals an enigma to both Creole whites and British observers across the Atlantic.

Such mystery and added disconnection from white-colonial networks further advanced the profile of mixed-race Jamaicans. As Henrice Altink argues, the growth of the abolitionist movement, beginning in the 1770s and 80s, focused British attention on enslaved women's sexuality as well as that of the colonial whites. Multiple discourses emerged about miscegenation that gradually coalesced into a unified condemnation of the practice by the $1820 \mathrm{~s} .{ }^{42}$ This subsequently produced a metropolitan disdain for the growth of the Caribbean population of colour that abolitionism and the Revolution in St. Domingue only exacerbated. ${ }^{43}$ These discourses did not emerge solely through speculative concerns transmitted through the popular and pro-slavery press. Rather, they were founded in the realities of a white West-Indian society with strong, personal connections with mixed-race individuals. Those connections not only lasted when members of that white society travelled back to Britain, but continued to play an important part in absentee life.

At the turn of the nineteenth century, British racial attitudes were anything but divorced from personal involvement with colonial questions on race. Indeed, there was not a strict ideological divide between the colonies and the metropole on these topics. ${ }^{44}$ Rather, white-colonial interaction and relation to individuals of mixed-race, and by default their networks back in Britain, put members on both sides of the Atlantic at the centre of the Empire's most controversial racial issue. Jamaica's people of colour were not a wholly segregated community, nor were they hidden from British eyes. Their role in the colonial family gave them a prominent place in Britain's imperial

41 Arnold Sio has argued against claims that the free coloured population was not unified. With the exception of, perhaps, Barbados, this unity came about rather late, and certainly did not congeal until the late $1810 \mathrm{~s}$, at the beginning of the emancipation movement. See Sio (1987).

42 See Altink (2005).

43 For a discussion of the cultural portrayals of mixed-race individuals in Britain in the midnineteenth century, see Brody (1998).

44 See, in particular, Wheeler (2000); Wilson (2003). 
networks and in the consciousness of British minds. The success of Jamaica's mixed-race population to negotiate that prominence and social power ultimately helped them to escape the more brutal effects of the West-Indian system of enslavement.

\section{Works Cited}

\section{Manuscripts}

Baptism Register, St. Andrew Parish, Jamaica Archives, Spanish Town, Jamaica.

Charles Angus Letter Book, Gifts and Deposits, Jamaica Archives, Spanish Town, Jamaica.

Colonial Office Records, National Archives of England, Kew.

Gordons of Buthlaw and Cairness Estate and Family Papers, University of Aberdeen Library, Special Collections, Aberdeen, Scotland.

Grange Estate Papers, National Archives of Scotland, Edinburgh.

Jamaica, Great Britain. Laws, Statutes, etc.

James Stothert Letters, William Clements Library, The University of Michigan, Ann Arbor, MI, USA.

National Library of Jamaica, Kingston, Jamaica.

Roger Hope Elletson Letter Book, National Library of Jamaica, Kingston, Jamaica.

Simon Taylor Papers, Institute of Commonwealth Studies, London.

Tailyour Papers, William Clements Library, The University of Michigan, Ann Arbor, MI, USA.

Thomas Thistlewood Papers, microfilm.

Published Works

Altink, Henrice (2005): "Forbidden Fruit: Pro-Slavery Attitudes Towards Enslaved Women's Sexuality and Interracial Sex," in: Journal of Caribbean History 39 (2), 214-23.

Brody, Jennifer DeVere (1998): Impossible Purities: Blackness, Femininity and Victorian Culture. Durham, NC: Duke University Press.

Burnard, Trevor (2004): Mastery, Tyranny, and Desire: Thomas Thistlewood and His Slaves in the Anglo-Jamaican World. Chapel Hill: University of North Carolina Press.

Bush, Barbara (1990): Slave Women in Caribbean Society: 1650-1838. Bloomington, IN: Indiana University Press.

Garraway, Dorris (2005): The Libertine Colony: Creolization in the Early French Caribbean. Durham, NC: Duke University Press.

Hall, Douglas (1989): In Miserable Slavery: Thomas Thistlewood in Jamaica, 17501786. Macmillan: London. 
Hall, N. A. T. (1975): "Some aspects of the deficiency question in Jamaica in the eighteenth century," in: Caribbean Studies 14 (1), 5-19.

Heuman, Gad (1981): Between Black and White: Race, Politics, and the Free Coloreds in Jamaica, 1792-1865. Westport, CT: Greenwood Press.

Karras, Alan (1992): Sojourners in the Sun: Scottish Migrants in Jamaica and the Chesapeake, 1740-1800. Ithaca, NY: Cornell University Press.

Moreton, J.B (1790): Manners and Customs in the West India Islands. London: W. Richardson.

Morgan, Jennifer (2004): Laboring Women: Reproduction and Gender in New World Slavery. Philadelphia: University of Pennsylvania Press.

Nugent, Lady Maria (1966): Lady Nugent's Journal of her Residence in Jamaica from 1801 to 1805, Philip Wright, ed. Kingston, Jamaica: Institute of Jamaica.

Shepherd, Verene, ed. (1999): Women in Caribbean History: The British-Colonised Territories. Kingston, Jamaica: Ian Randle Publishers.

Sio, Arnold (1987): "Marginality and Free Coloured Identity in Caribbean Slave Society," in: Slavery and Abolition 8 (1), 166-81.

Wheeler, Roxann (2000): The Complexion of Race: Categories of Difference in Eighteenth-Century British Culture. Philadelphia: University of Pennsylvania Press.

Wilson, Kathleen (2003): The Island Race: Englishness, Empire and Gender in the Eighteenth Century. New York: Routledge. 


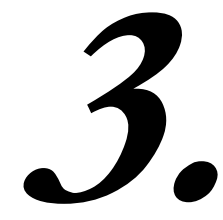

Detecting Post-Emancipatory
Forms of Slavery 

Slavery Is Sustained by the Purchase of its Productions: The

Slave; His Wrongs and Their Remedy (1851-1856)

Sean Creighton ${ }^{1}$

\section{Introduction}

The Slave; His Wrongs and their Remedy was started in January 1851 as a monthly newspaper by Anna and Henry Richardson, prominent North East Quaker abolitionists, as a vehicle for providing information about slavery and to promote free labour produce. They edited it until the end of 1854, when due to Henry being ill, it was transferred to Elihu Burritt, the American abolitionist and peace campaigner. Its masthead slogan stated "Slavery is sustained by the purchase of its productions. If there were no consumers of slaveproduce, there would be no slaves." This essay reviews the abolitionist context, the purpose and coverage of the newspaper and gives a preliminary assessment of its importance.

\section{The North East, Abolition and Free Labour Produce}

When the Richardsons started The Slave they were building on five existing initiatives. The first was Illustrations of Slavery, the monthly newssheet they had been sending to about 100 newspapers editors since 1847. Compiled chiefly from American newspapers and correspondence, they claimed that "many striking articles" had "received

1 Acknowledgements: Thanks to John Charlton, Patricia Hix and Elizabeth O'Donnell of the North East Slavery \& Abolition Group for information and comments, and Jack Drum Theatre for commissioning me to advise on its slavery and abolition play Sharp Practice which enabled me to study The Slave. 
a wide circulation by this means, at a very small expense." 2 The second was the free produce associations started on Anna's initiative through the Newcastle-upon-Tyne's Ladies Negro Friend \& Emancipation Society (hereinafter called The Ladies Emancipation Society). The third was the series of Anti-Slavery Free Labour Tracts, sometimes referred to as the 'Newcastle Tracts', published by the printers William Pringle in Newcastle and Charles Gilpin in London. The fourth was the Richardsons' involvement in the local Peace Society, through which they would have met Elihu Burritt when he spoke in Newcastle in November 1846 and February 1849. ${ }^{3}$ Finally, they were editors of a peace movement periodical The Olive Leaf. The Slave was designed to provide the type of stories about slavery that had been in the Illustrations, to advocate the free produce movement and report on anti-slavery activity. The Richardsons ran the paper from their homes at 5 Summerhill Grove and then at 45 Westmoreland Terrace in the Quaker enclave on Newcastle's western side. ${ }^{4}$

The importance of The Slave can best be understood within the context of the development of the North East as a strong regional base for activities against British colonial slavery from the late 1780s. Central to the regional abolitionist network were the Quakers and the Unitarians. As Clare Midgley has shown, women played an important role. Having achieved emancipation in most of the British colonial territories in 1838, the core of North East activists took up the fight against slavery in other parts of the world, especially the United States. ${ }^{5}$ It thus hardly comes as a surprise that a strong contingent from the region attended the World Anti-Slavery Convention in London in 1840. One of the Darlington delegates, James Sams, argued that if the British "as a nation, were to use only free labour produce, it would be one of the severest blows which possibly could be given to slavery." The British and Foreign Anti-Slavery Society also encouraged support for buying free labour produce. By 1845 demand was sufficiently large for a leaflet to be published, "The Ladies' Free-Grown Cotton Movement", listing the names of manufac-

\author{
2 The Slave (1851), No. 1, 1. \\ 3 Burritt (1849). \\ 4 The Slave (1851), No. 5, 20. \\ 5 See Charlton (2008), Midgley (1992) and O’Donnell (2009). \\ 6 BFASS (1841), 53.
}


turers and wholesale and retail drapers who sold free grown cotton goods. ${ }^{7}$

\section{The Richardsons}

Anna grew up in Chipping Norton in Oxfordshire in the Quaker Atkins household which refused to use slave grown sugar and assisted black beggars as they may have been runaways from slavery. In 1833 she married Henry and moved to Newcastle. She became Secretary of the new Ladies Bible Society, Treasurer of the Ladies Emancipation Society from October 1838, and set up a Women's Bible Mission. ${ }^{8}$

Image 1: Henry and Anna H. Richardson, the editors of The Slave, date unknown
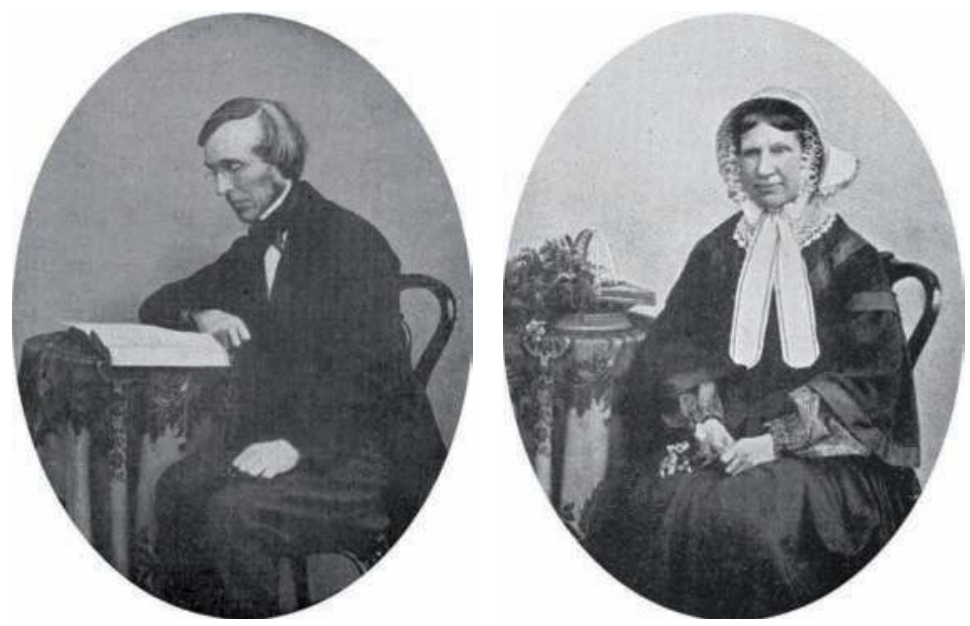

Source: Steel (1899), 190. Courtesy of The Library of the Religious Society of Friends in Britain.

Fugitive slaves from the United States and abolitionist campaigners found a warm welcome on Tyneside. Frederick Douglass stayed with the Richardsons in late 1846 during his 1845-47 lecture

7 Poulter (2008).

8 Midgley (1995), 28. 
tour. Anna and Ellen Richardson raised the money to buy his freedom in $1846 .{ }^{9}$ Known as paying "the ransom," this act of solidarity was criticised. Douglass defended them because their "actuating motive was, to secure me from a liability full of horrible forebodings to myself and family." 10 Being free Douglass was able to return to the States without fear of being captured as an escaped slave. He was followed by Anna's friend, Julia Griffiths as his assistant and fundraiser. ${ }^{11}$ In 1846 Henry and Anna proposed to start the Illustrations of Slavery briefings to editors. This was supported by the Ladies Emancipation Society which contributed $£ 3$ towards the expenses. ${ }^{12}$

\section{Building the Free Labour Produce Movement}

In November 1845 Henry wrote to the Quaker newspaper The British Friend pointing out the inconsistency of rejecting slave-grown sugar while accepting slave-grown cotton. The argument of those willing to do so was the insufficiency of free-grown cotton to replace it. Free grown cotton was available in Liverpool but its inferior quality would necessitate its 'working up' with better quality produce. Newcastle had "three extensive manufacturing firms" ready to work up the cotton "as soon as it shall arrive in sufficient Quantities to enable them to keep it distinct without loss." A free-labour warehouse was needed in London and he asked, "can our London Friends turn their attention to the supply of this desiderata?"13

The energy that the Richardsons and others put into their activities, and the way they could advance their causes through other means, meant that the Ladies Emancipation Society did not meet between 11 December 1846 and 26 February 1850. It appears that in 1849 Anna invited the black abolitionist Henry Highland Garnet to come to Britain. ${ }^{14}$ The choice of Garnet is interesting given Anna's support for Frederick Douglass. Writing about the planned trip to Britain in 1849, Douglass praised Garnet as a speaker, but regarded him as an enemy because Garnet "had no faith in moral means for

9 Midgley (1992), 139 and Wright (1846), 4.

10 Wright (1846), 7.

11 Midgley (1992), 125.

12 Ladies Emancipation Society (1838-1854).

13 Sansbury (1998), 167.

14 Midgley (1992), 138; (1995), 30, says it was 1850. 
the overthrow of American Slavery: - that his hope for success was in the sword [...]." 15 On 27 February 1850 the Ladies Emancipation Society met to hear Garnet lecture. A sub-committee including Anna was established to promote the cause. It was agreed to purchase 1,500 copies of the Newcastle tracts for Garnet's use. ${ }^{16}$ Garnet's friend, Dr John Pennington, another escaped slave campaigner, spoke to the Society on 16 April about the importance of increasing the demand for free labour produce. ${ }^{17}$ Garnet toured, especially in the North and Scotland, and was back in Newcastle in September. On 4 September he wrote to his cousin Samuel Ringgold Ward saying that Anna would be happy to send him free produce documents for use in his newspaper Impartial Citizen. ${ }^{18}$ Garnet spoke to the Ladies Emancipation Society on 12 September and it agreed to appoint him as its Travelling Agent and to reimburse his costs of travelling from New York. ${ }^{19}$

Garnet's campaigning was clearly successful, especially in North Britain. As the Richardsons explained in the first issue of The Slave while the movement "had been gradually gaining strength" Garnet's arrival "gave it an impetus which bids fair to place it amongst the popular movements of the day." By December 1850 there were Free Labour Associations in Birmingham, Bristol, Coldstream, Darling on Dunse, Hitchin, London, Luton, Newport, Peckham, Worcester, Carlisle, Maryport, Whitehaven, Workington, Alnwick, Berwick, Blaydon, Gateshead, Hartlepool, Middlesbrough, Newcastle-uponTyne, North Shields, Sunderland, Stockton, South Shields, and Winlaton. This work had been accompanied by the issuing of more than a hundred thousand free-labour tracts and papers from the press at Newcastle in the last three months of 1850. Despite this, according to the Richardsons, "it has been found extremely difficult to meet the demand for information on this important branch of the anti-slavery enterprise." 20 The Slave therefore was the next step in helping to disseminate information. Its publication gave encouragement to the free labour movement abolitionists in the United States

15 Douglass (1849).

16 Ladies Emancipation Society, 27 February 1850.

17 Ladies Emancipation Society, 16 April 1850.

18 Ripley (1985), Letter 27.

19 Ladies Emancipation Society, September 1850.

20 The Slave (1851) No. 1, 4. 
who were feeling despondent about the failure of one of their initiatives and about the Fugitive Slave Act of $1850 .^{21}$

\section{The Editorial Approach to The Slave}

Reading through it, The Slave appears to be very fragmentary. The many stories of "The Horrors of Slavery" were counterbalanced by stories of progress and hope with individual slave owners granting freedom to their slaves and the escape of slaves. There are items about the growth of free cotton production around the world, and anti-slavery activity in Britain. Many items are extracts from other publications. The Richardsons argued that if they just "repeated tales of woe, without affording the opportunity for corresponding action for its relief" it would be "liable to induce a morbid state of mind, and does more harm than good." The free-labour movement provided positive action involving only a small sacrifice. ${ }^{22}$ Individuals could be involved at a personal level in terms of what they could buy. There were also courses of collective action as well, which is why the Richardsons gave coverage to all kinds of anti-slavery activity. Poems were inserted, mainly American, suggesting that the Richardsons understood their audiences by lightening the content for more popular consumption. It was through the editorials that they knitted the fragments together, showing the beneficial effects of a holistic approach.

The next sections of this essay will discuss some aspects of the The Slave's diverse contents: the horrors of slavery, Garland's work, reporting and encouraging anti-slavery activity, the Black voice and experience, the supply of free produce, the case for free labour, and the apparent conflict with free trade principles.

\section{The Horrors of Slavery}

Readers were kept up-to-date with stories showing the inhumanity of the slave system under a section called "Illustrations of Slavery", representing continuity with the previous briefings sent to newspaper editors. The stories were drawn from American city, state and 
abolitionist papers, especially the Pennsylvania Freeman and Frederick Douglass's papers. Coverage included slave auctions, the selling price of slaves, the splitting up of families, the experience of imprisonment, escape and re-capture of individuals, and the savage treatment that was meted out to white abolitionists. Stories could be particularly horrifying like the one about "Three Children eaten by bloodhounds in pursuit of negroes." 23 While most of the stories were from the United States, there were occasional items about Latin America, particularly Brazil and Cuba.

There were also stories of successful escapes to the Northern States and Canada, about owners freeing their slaves, and assisting them to start new lives. "Illustrations" highlighted the operation of the Fugitive Slave Law of 1850 which allowed federal agents to seize escaped slaves living in free states and return them to their owners. The number of fugitives from particular areas was noted as having an effect in significantly reducing the size of congregations attending 'coloured churches'. ${ }^{24}$ The danger the Fugitive Slave Act posed to escaped black abolitionists when they returned from Britain to the United States strengthened the resolve of some British abolitionists to buy individuals' freedom, as in the case of Dr Pennington, organised by members of the Free Labour Association in Dunse. ${ }^{25}$ Later supporters paid for the freedom of William Wells Brown. ${ }^{26}$

\section{“Garnet's Labours"}

Henry Highland Garnet continued his advocacy tours. While the Richardsons report "Garnet's Labours" as being very successful, only two more associations appear to have been established - in Dublin and Walthamstow. His work, however, appears to have assisted the general growth in support for anti-slavery and free produce. In Ireland in 1851 he spoke at meetings at Bangor, Lisburn, Lochoughry, Grevechy, Dromore, and several other places. "It is deemed very important that the Anti-slavery Case should be kept before the people of Ireland, in as much as that country furnishes so many emigrants to the United States," especially given the remark of 
the Earl of Carlisle, "that the Irish in America are the worst enemies of emancipation." 27 In November he addressed meetings in Glasgow, Edinburgh, Greenock, Paisley, Ellensboro, Hamilton, Falkirk, Kirkcaldy, and Dundee. He and his family settled in at 89 Blandford Street in Newcastle. At a Soiree held on 13 January 1852 the town's religious leaders and others welcomed them. Several resolutions were adopted regretting the continuance of American Slavery and the extent to which American Christians and churches were implicated, and calling on them "to employ the best means for its speedy and complete termination." The meeting rejoiced at the "multitudes of fugitives" who had made their escape into the British dominions and welcomed Garnet and his family. Finally it recommended the Free Labour movement. ${ }^{28}$

In February Garnet was in Scotland at Ayr, Stewarton, Cumnock, Dalty, Kilmarnock, Kilpatrick, Falkirk, Campsie, Alloa, Greenock, and Glasgow. ${ }^{29}$ His "A Plea for the Bondsman" was available as a Newcastle tract. ${ }^{30}$ There is then a gap in news about him, until a lecture in Walthamstow on 5 August and another tour of Scotland. ${ }^{31}$ While in Glasgow in October helping with the antislavery bazaar he wrote to the Richardsons telling them that he would be sailing for Jamaica from Southampton in November. ${ }^{32}$ The plan to appoint him as a missionary to Jamaica had been known about for several months and was endorsed at a Presbyterian public meeting on 19 October in Edinburgh. ${ }^{33} \mathrm{He}$ continued to correspond with the Richardsons about his journey to and after his arrival in Jamaica. ${ }^{34}$

While Garnet had been in Glasgow, the news broke through The Slave about the need to raise money to buy freedom for his relatives, the Weims. Although John Weims was a freed man, his wife and one of his children were still slaves. The personal identification with Garnet, whom so many people had met and heard speak, probably meant there were more supporters sending their donations

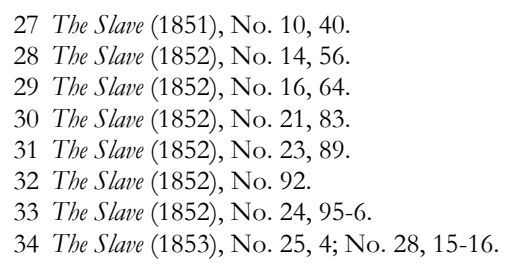


to George Gallie in Glasgow, Edmund Sturge in Birmingham, and Henry Richardson in Newcastle. ${ }^{35}$ The continuing story of the Weims was followed. ${ }^{36}$ As with Douglass there was criticism, especially on the grounds that it was a kind of 'purchase'. The Richardsons made it clear that "we do not purchase the slaves, but merely the manumission papers, which give them a legal title to freedom [...]. Ransom encourages the slave owner to perform an act of justice." Critics also argued that the money would be better spent on general emancipation activity. The Richardsons replied that some people would contribute to relief of individual suffering rather than to abolition societies. The critics said that ransom did little to relieve the general misery and led to higher valuation and tougher treatment of those who remained slaves. The Richardsons' reply was that less than three years after Douglass's 'ransom', his former owner had emancipated all his slaves bar Douglass's grandmother, whom he had taken into his household. ${ }^{37}$

\section{Reporting and Encouraging Anti-Slavery Action}

While the Richardsons regretted the lack of hundreds of strong free produce associations, and despite the fact that many of those that did exist were "feeble", they were not "discouraged" because "a conviction of the righteousness of our principles is increasing" among business firms and Christians. ${ }^{38}$ It is clear that several associations were involved in wider anti-slavery activity. In late 1850 and early 1851 members in Berwick-on-Tweed were debating with members of the Free Church on the Borders of Scotland about cutting their links with pro-slavery churches in the United States. ${ }^{39}$ "Conscience versus Cotton" written by a Walthamstow member, probably Sarah Cogan, was published as a Newcastle tract. ${ }^{40}$ The newspaper thus played a connecting role within the broader anti-slavery movement. It reported half-a-million signatures collected on an open

35 The Slave (1852), No. 23, 89.

36 The Slave (1852), No. 24, 93-4; No. 25, 2-3; The Slave (1853), No. 2, 5-6.

37 The Slave (1852), No. 24, 94-5.

38 The Slave (1851), No. 8, 31.

39 The Slave (1851), No. 1, 3.

40 The Slave (1851), No. 8, 31-32; The Slave (1852), No. 15, 60. Cogan is referred to as the author in Ladies Emancipation Society (1838-1854). 
document of remonstrances of anti-slavery addressed to the Americans, the "Uncle-Tom's Cabin" One-Penny Readings collection to give to Harriet Beecher Stowe to spend as she saw fit on the American anti-slavery cause, and Stowe's tour. ${ }^{41}$

The publication of tracts was noted or advertised, like that by Pringle in Newcastle of the anti-slavery speeches of US Senator Charles Sumner, and of Congressmen Horace Mann. ${ }^{42}$ In January 1853 the Newcastle tract "Tariff of Conscience" was re-issued containing "a reply to the various objections that have been made against the Free-Labour Movement. Many thousand copies have been already disposed of, and the present edition is brought out to meet the still existing demand." 43 It was further noted in May 1853 that a "rapid increase of anti-slavery publications, in this country, would seem to indicate an anti-slavery revival." The Richardsons cited that Pringle published the tract American Slavery Discussed in Colonies, the monthly magazine The Friend of the Fugitive and AntiSlavery Record started in April under auspices of the Glasgow Female New Association for the Abolition of Slavery, the Dublin based The Anti-Slavery Advocate, and The Anti-Slavery Reporter. The print run for The Slave was increased by 500 . There was also the issue from Leeds of Half-a Million anti-slavery tracts, of 83 varieties. ${ }^{44}$ Archbishop Whately was supporting the free-labour cause. Carline ginghams were now available from the Carlisle based Cumberland Co-operative Freelabour Cotton Gingham Company. ${ }^{45}$

There were reports on abolitionist co-operation across the Atlantic. Miss Pringle of Newcastle was accepting donations to ship to the 1851 New York Vigilance Fugitive Slave Bazaar in New York. ${ }^{46}$ It was later reported that "the most valuable contributions were those received from England and Scotland." Miss Pringle and Glasgow's Mrs Muir were organising for the next one. ${ }^{47}$ Towards the end of 1854 the Glasgow abolitionists shipped three boxes, containing $£ 130$ of goods, for the New York Bazaar. ${ }^{48}$ The Philadelphia Free 
Produce Association was supplied with clothes made with free labour cotton by the Carlisle Co-operative. ${ }^{49}$

The Richardsons gave advice on other actions supporters could take, particularly on how to treat American slave owners attending the Great Exhibition in 1851 and the many church, temperance and peace gatherings in London that year and in 1852. "Tell the slaveholder his faults faithfully; and if he refuses to hear us, then place him under the ban of social excommunication. [...] let us all do the best we can to show them that in this England [...] while the slave is in peace, the slave-holder is the fugitive." Their firm position was underpinned by their disgust of the white churches in America, which they regarded as the main bulwarks of slavery, with 660,563 being owned by ministers and members of congregations, the slaves being valued at nearly $f, 53 \mathrm{~m} .{ }^{50}$ To those who considered their advice to be harsh the Richardsons pointed out that when "the American Bible Society gave a bible to every family in the United States slaves were excluded," that the American Presbyterian The Missionary Chronicle talked about work with Chinese, Red Indians, 'Hindoos' but not with slaves, and that in re-printing British publications the Religious Tract Society of America suppressed "every allusion to the sin of slavery." ${ }^{51}$

\section{The Black Voice and Experience}

One of the most significant aspects of The Slave is the inclusion of "black voices": Garnet, Pennington, Douglass and others, including the plea from Antiguan labourers, "Tell them no buy slave sugar, that mixed with blood; but buy Antiguan, no blood in that now, massa." 52 In a letter from Ockham School in Surrey dated 25 October 1852 William Craft endorsed Uncle Tom's Cabin as "a very true picture indeed of American slavery." He also reported the birth of his and his wife Ellen's "first free-born babe." 53 Garnet and his wife also had a baby while in Britain. ${ }^{54}$ Given their involvement in philan-

49 The Slave (1854), No. 37, 52.

50 The Slave (1851), No. 4, 14-15.

51 The Slave (1852), No. 17, 67-68

52 The Slave (1852), No. 19, 76.

53 The Slave (1852), No. 24, 96.

54 The Slave (1852), 93-94. 
thropic work in Newcastle it is perhaps no surprise that the Richardsons were able to see comparisons between the experiences of slaves and British workers.

Without stopping to detail the miseries endured too generally on these plantations, we may remind our readers that the physical condition of the slave is by no means better than in the cotton districts. There are the same miserable dwellings - the same scanty clothing, and coarse, or even unwholesome, food - the same driving and flogging, though practised often with still more severity. Nor does the moral condition of the slave present an aspect at all more favourable. There is the same disregard of the holy tie of marriage - the same systematic withholding of education - the same shutting out of the Bible and its glorious truths. ${ }^{55}$

\section{The Supply of Free Labour Produce}

The remedy to slavery was to buy free labour produce. This was dealt with in the editorial column "The Remedy". To boost readers' positivity about the effect of their individual and collective actions, the Richardsons reported on increases in free labour cotton production around the world, such as the sale of 1,452 bales of East India cotton in Manchester, the invention of flax cotton and the experiments with it by Chevalier Claussen at Quitzow and Co's mill, near Bradford." 56 They pinpointed "the two greatest difficulties in the way of the Free Labour movement" - "capacity" and "deficient supply." 57

One of the functions of the newspaper was advertising where free labour produce could be obtained. Manchester and London were seen as the two major locations for wholesale depots. At the beginning of 1851 Manchester already had the free produce warehouse of Josiah F. Browne and Co. marketing finished cotton products manufactured by Crewdson \& Worthington and other firms. The first issue of The Slave argues for more capital, and reports on the efforts to set up a similar warehouse in London. ${ }^{58}$ As well as de- 
pots and warehouses a number of drapers and grocers offered free labour produce. The Slave occasionally listed them. In addition to Browne, Joseph Chrimes sold cottons in Manchester. In London cottons were sold by J \& R Morley of Wood Street, Cheapside, and Burtenshaw and Gande of 45 Fore Street, while in Lancaster there was Barrow \& Satterthwaite. Sugars could be obtained from Startin \& Fry at 150 Fenchurch St, London, the Leith Sugar Refining Company, and Walker and Wall in Sheffield. ${ }^{59}$

It appears that the Richardsons were mainly advertising wholesalers rather than retailers, because there must have been a whole network of shops run by abolitionist supporters, which stocked free labour produce, including coffee, rice and spices. Free labour produce was sold at Peace Bazaars. A Liverpool cotton broker provided 16 sorts of free cotton for the Free Labour stall at the 1851 Peace Bazaar in London. ${ }^{60}$ During the Great Exhibition they recommended seeing the Irish display of "exquisite collections made from flax." ${ }_{11}$ By the end of December 1854 William Lees had opened a London depot at 72 Bishopsgate Within supplying free-labour groceries. There was also Mrs Inglis's Free Labour Depot for cotton goods, started in Blomfield Street, Finsbury Circus, and moved to larger premises at 22 Broad Street Buildings. ${ }^{62}$ In his tract Twenty Reasons Elihu Burritt stated that "The only object of opening this depot is to promote a great and philanthropic movement for the abolition of slavery throughout the world, and it will endeavour to assist in establishing similar depôts in the provincial towns, by supplying them with any lengths or parts of pieces at the wholesale prices." 63 The major draw-back, however, remained the shortage and quality of supply. Following a visit to Mrs. Inglis's depot the Richardsons expressed concern about the fact that "manufacturers have to take what there is in the market, and thus is occasionally a little too coarse, or a little too fine and tender for their purposes. All this will be surmounted as a larger supply of free-labour cotton comes in." 64

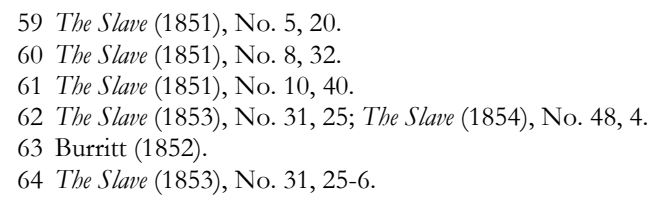




\section{The Case for Free Labour}

The editorial was used to defend the free labour movement against its critics. This was partly to reassure readers that it was worth persevering with seeking to buy free labour produce. For the Richardsons slavery was "the most powerful opponent of the gospel, and the enemy of civil liberty, and the destroyer of human happiness." 65 "Substitute the labour of the free for the labour of the slave, and you abolish slavery." They argued that the British could not "expect to bear an effective protest against slavery, unless we first clear our own hands of the iniquity, by refusing, as much as possible, to participate in its spoils." 66 They continued that

The consumers of slave-produce, taken in the aggregate, are, after all, the chief gainers of slave labour [...]. The consumer [...] remonstrating the slave-holder, is like the man who wishes to reform a thief, and prefaces his lecture by purchasing some of his stolen wares; [...] The abstainer [...] occupies a vantage ground from which he may assail with effect the unrighteous system. ${ }^{67}$

Despite being peace activists they talked in military terms: from Britain "we only have the opportunity of pouring in a distant cannonade. [...] We have no political connection to dissolve [or] religious connection to withdraw from. But we [...] have commercial union [...]. The American cotton-field is the grand nursery of American slavery; and more than one half of the American cotton crop finds its way to England!" They furthermore argued that the British needed "to be informed, directed, stimulated to action."

If multitudes of English radicals, during the struggle for parliamentary reform, could renounce the luxury of tea and coffee, and betake themselves of roasted grain as a substitute [...]; do not let us despair of inducing the working men of England to use a little discrimination in purchasing articles of clothing, when the personal liberty of three million is at stake. ${ }^{6}$

They pointed out that the free labour movement had "been made the butt of heartless ridicule and unsparing condemnation [...] by some whom we cannot hesitate to believe to be genuine abolition- 
ists." It had been accused of "diverting attention from the true seat of the disease, and exhausting the energies which might be directed to its cure." Another objection was that slave produce would simply be sold elsewhere, "the only change being a change of customers." The Richardsons were robust in their rejection of these criticisms. Acknowledging that active support was very small, "we do not believe that the free-labour movement will, of itself, abolish slavery," but "is an efficient auxiliary for the abolition of slavery, and that without the free-labour principle, the anti-slavery character is incomplete. [...] A large order to a slave plantation means more toil, more whipping, more disease, more death! A similar order to a free plantation means more hiring, more wages, more comfort, more prosperity!' ${ }^{69}$

Another objection was that total abstinence was impracticable. The Richardsons' riposte was that "the inability to do all that we could wish is a very poor excuse for not doing what we can." There were many products in which the element of slave production "would be so difficult to trace, and so infinitesimal when discovered that it does not need to disturb our consciences." ${ }^{\prime 70}$ They were horrified by the scale that slavery had reached, citing figures from The Anti-Slavery Reporter: 12,370,000, with 785,000 still in British Colonies and Canada. The "progress of civilization, during the last half century, has greatly promoted the growth of slavery," including Whitney's cotton gin, Arkwright's spinning-mule, the drop in production in the British colonies following emancipation causing increased production in Cuba and Brazil, and the change in duties putting free labour produce in the colonies at a disadvantage. ${ }^{71}$ In this respect they claimed that "The slave-holder's broad denial of the rights of man, cancels his own claim to the rights of commerce." 72 The "unreluctant assent and consent to the purchase of the slaveholders' wares, [...] compromised our duty to the Free, as well as to the Slave [...]. Self-purification, from a voluntary participation in the guilt of slaveholders, is the very essence of the "Free-labour Movement!"'73 


\section{The Problem of Free Trade}

Initially the Richardsons concentrated a lot of coverage on cotton because in the second half of the 1840s over three-quarters of its imports to Britain had come from the United States, whereas slave produced sugar, coffee, and rice was "the exception." 74 Their position on these other goods began to change as they recognised that there would be an increase in quantities being imported with the planned staged withdrawal of differential duties on free and slavegrown sugars to zero in 1854 and coffee from $1852 . .^{75}$ One of the main objections to the movement was its apparent conflict with the principles of free trade. Yes it "is a restriction on Free Trade" replied the Richardsons; but ultimately "it is an extension and amplification of the principle." Even the "most zealous Free Trader" recognised that there were exceptions to general rules: the slave trade, stolen and smuggled goods. The "productions of Negro Slavery should be added to the prescribed list," because they "are dishonestly obtained." "To produce an article from the soil, it is needful to bring together land, capital, and labour. It is from labour only that land and capital derived their value for such purposes. To the honest cultivator, the wages of labour form a heavy item in the cost of production." Comparing the costs of daily upkeep of slaves in Porto Rico with the day wages in the British West Indies "it is clear that the slave-holder defrauds his Negro to the extent of 9d. for every working day; and whatever proportion of this may bear to the total cost of sugar, it must be obvious that, to the same extent, is the sugar dishonestly obtained [...]." So slavery denied the Free Trade principle that "every man has a right to buy in the cheapest market [...] and sell in the dearest." Until slavery is ended the principle of Free Trade will not "be carried out to its legitimate extent." 76 They were delighted to be able to report that one free trade advocate, Col. Thompson, the veteran of the anti-corn law agitation, was arguing "that free-trade principles by no means involve a purchasing in the 'thief market', even if that be occasionally the cheapest." 77 The predicted increase in slave sugar on the market was compounded by consumers demanding "crushed, or re-manufactured sugars, the origin of which

74 The Slave (1851), No. 2, 7.

75 The Slave (1851), No. 7, 27; The Slave (1852), No. 17, 68.

76 The Slave (1851), No. 9, 34-5.

77 The Slave (1853), No. 31, 25. 
(whether free or slave) is generally left in obscurity, the shopkeepers having no means of ascertaining it." The Richardsons advised "antislavery friends" to "always insist on being supplied with free-grown sugar, and be content with the raw and unmixed produce of our own colonies," unless the manufactured article was guaranteed free labour. They urged anti-slavery grocers to press refiners to manufacture specific free-labour sugars. ${ }^{78}$ They were, however, hopeful that "the depression of free-labour interests of our colonies is temporary" partly because free labour had elasticity while the slave system did not. ${ }^{79}$

\section{Editorial Problems}

The Richardsons experienced difficulties with their newspaper. By December 1851 they had published eleven issues. Although they had been printing 4,000 copies, they had not been able to sell them all. Under the heading "Our Own Concerns" they explained that several thousand back numbers had accumulated and offered them "at the reduced price of 20s per thousand." 80 Whether this was successful is not clear. Two months later they reported, "We are sorry to inform our friends that The Slave has been hitherto a loss making concern." 81 Although the print run was increased in 1853, the cholera outbreak on the Tyne in the autumn of that year caused them serious difficulties. They apologised stating that "In the present state of our town, we freely acknowledge our inability to give our readers more than simple extracts upon the anti-slavery and free-labour subjects. The cholera is raging around us fearfully, and, with the utter uncertainty respecting who may be summonsed next [...]." 82 By the end of 1854 Henry Richardson was ill and Anna had to reduce her commitments in order to look after him. She transferred The Slave to the management of Elihu Burritt and Edmund Fry. 83 


\section{Elihu Burritt Editorship}

The new address for The Slave was the London Labour Depot at 22 Broad St Buildings, but printing continued to be carried out by Pringle in Newcastle and W. \& F. G. Cash, a firm that had taken over from Charles Gilpin in London. Burritt continued the Richardsons' editorial approach. There was news about the increasing bitterness and conflict over the expansion of slavery especially in Kansas. Among free labour produce initiatives reported on in the United States was an Englishman setting up a Free-Labour Colony in a Slave State, a Frenchman following suit in Texas, while Germans had turned to producing free cotton in Slave States. ${ }^{84}$ Burritt identified the need to "indoctrinate" British immigrants to the United States in the principles of anti-slavery. ${ }^{85}$ Reportage of anti-slavery activities continued, like the approx. $£ 1,000$ made at the Anti-Slavery Bazaar in Boston as a result of "the great variety of contributions from the continent of Europe, showing how deeply the thrilling recitals of "Uncle Tom's Cabin touched the hearts of thousands in those foreign countries." 86 There was occasional news about slavery elsewhere, including its existence in Java, its abolition in Peru and issues of slavery in Cuba and Turkey. ${ }^{87}$ Activities in Britain continued to be covered like the work of the Glasgow New Association for the Abolition of Slavery, which included reference to a $£, 5$ donation to Henry Richardson for the Free Labour movement, and a summary of the Annual Report of the Edinburgh Ladies' Emancipation Society. ${ }^{88}$ A Free Labour Bazaar scheduled from Wednesday 30 May to Friday 1 June at the Hall of Commerce in Threadneedle Street was extended for an extra day with total sales of $f .418 .17 \mathrm{~s} .9 \mathrm{~d} .{ }^{89}$

Burritt was full of ideas. He promoted the idea of establishing a National Association for Promoting the Growth of Cotton in the British Colonies. This incorporated the idea of the Free-Labour Premium Plan to build up a Fund. By April donations had started to come in and he toured Northern England and Scotland to promote

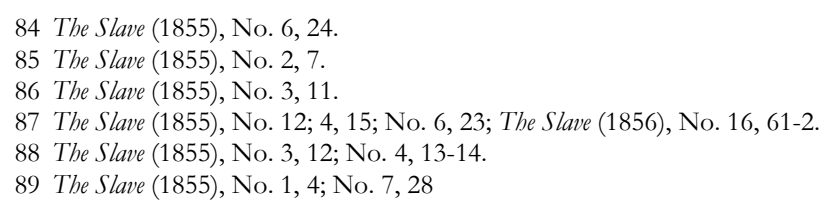


the Fund..$^{90}$ He then announced his intention to go to America to promote the plan. The October 1855 issue was the last before Burritt went to the States. ${ }^{91}$

\section{Burritt Goes to the United States}

It is not clear how Burritt and Fry assembled the paper with the former in the States. Burritt must have sent editorials and news from the States, such as his welcoming the formation of the new radical anti-slavery party by Arthur Tappan, Frederick Douglass and others. ${ }^{92}$ Items about free labour published in his other newspaper Citizen of the World were reproduced..$^{3}$ He developed a plan for extinguishing slavery by compensation, discussed in a series of articles in early $1856 .{ }^{94}$ Garnet wrote from Jamaica on the continuing problems facing members of the Weims family, including the death of his adopted daughter Stella. ${ }^{95}$ There were reports on the Weims Ransom Fund, and on Harriet Beecher Stowe's new anti-slavery novel Dred and her tour of Scotland. ${ }^{96}$ There was information on the work of the Edinburgh, Glasgow and Dundee Ladies Anti-Slavery societies and on the Annual Meeting of the British and Foreign Anti-Slavery Society held on 19 May. ${ }^{97}$ Bessie Inglis handed over the London Depot to Mrs Martha Bowden of Gracechurch Street. ${ }^{98}$ It would appear that the last issue was the one published in December 1856, although there is no editorial explanation that it would cease publication with the end of the year.

\section{Postscript}

Like all campaign instruments The Slave could only be sustained through the efforts of its promoters especially in covering the cost of publication. No doubt it became more and more difficult for Burritt

90 The Slave (1855), No. 3, 9-10; No. 4, 13; No. 6, 23-4; No. 7, 25.

91 The Slave (1855), No. 9, 36.

92 The Slave (1855), No. 12, 48.

93 e.g. The Slave (1856), No. 13, 49-51.

94 The Slave (1856), 51-52; No. 14, 54; No. 15, 57; No. 17, 66.

95 The Slave (1856), No. 14, 55-6.

96 The Slave (1856), No. 22, 85, 86; No. 23, 89-90.

97 The Slave (1856), No. 17, 67-8; No. 18, 72.

98 The Slave (1856), No. 17, 68; No. 19, 76. 
to keep The Slave going while touring the United States and editing Citizen of the World (1855-1856). He went on with his abolition and peace activities in different ways, for example, through the pacifist anti-slavery journal The North and South (1858-1859). During the American Civil War he was United States Consul in Birmingham. Garnet re-visited Britain in 1861 to promote the African Civilization Society he had founded in 1858 with Edward Blyden to promote black emigration from the States.

As for the Richardsons, Henry recovered from his illness. On the basis of current levels of knowledge it is not clear whether or not the level of abolitionist activity in the North East diminished in the second half of the 1850s. An "excellent" contribution of goods was sent from Newcastle in 1856, and money donated from Newcastle by John Mawson and Joseph Cowen the following year for the $\mathrm{Na}$ tional Bazaar in Boston, while a letter from Lady Londonderry at Seaham was quoted in the report for that year's Bazaar. ${ }^{99}$ In October 1859 Anna published an abolitionist tract for children in Newcastle entitled Little Laura: The Kentucky Abolitionist, based on the life of Laura Bailey (1846?-1856). ${ }^{100}$ In September 1860 she sent an account of her involvement in British anti-slavery activities to William Still who published it in his book The Underground Railway along with letters she wrote to him. ${ }^{101}$ In 1865 Henry Richardson wrote to the British \& Foreign Anti-Slavery Society commenting that the Newcastle Anti-Slavery and Emancipation Societies seemed to be extinct and the bulk of the anti-slavery work had fallen on Anna's shoulder for a long time. ${ }^{102}$ This is likely to reflect problems faced by Quaker abolitionists as pacifists during the Civil War which may have kept them aloof from the activities led by the national Emancipation Society. On Tyneside and in the North East this activity was led by Joseph Cowen, the radical Tyneside politician and owner of the Newcastle Weekly Chronicle, whose editor W. E. Adams wrote in support of the North and emancipation and addressed public meetings. ${ }^{103}$

With the end of the Civil War, attention turned to providing aid to newly freed slaves. Henry's 1865 letter reported that they had dis-

99 Chapman (1857), 8; Chapman et al. (1858), 14-15, 29.

100 Richardson (1859).

101 Still (1872), 593-608

102 Midgley (1995), 32.

103 See Todd (1991), Ashton (1991), 104-107, Adams (1968), 418-438. 
patched 20 barrels, bales etc. to New York and hoped to forward another consignment shortly. The non-denominational Newcastle Freedman's Aid Association with a separate ladies committee was formed on 11 March 1867 following a meeting in the Town Hall addressed by the former slave Rev. Sella Martin of the American Missionary Society and Rev. T. Phillips, secretary of the recently formed National Freedmen's Aid Union. ${ }^{104}$

\section{Conclusion}

The Slave provides invaluable information about slavery in the United States, anti-slavery activities there and in Britain, and the emerging free labour produce movement. It is just one example of the dedication individuals like Anna and Henry Richardson gave to the cause. How many people actually read the paper is not clear. However, the number of sales does not indicate potential influence, given that it was mainly purchased by anti-slavery activists, who were therefore provided with a continual digest of news and arguments that they could use in their activities. It is likely that anti-slavery organisations throughout the country may have purchased a copy and handed it round for people to look at their meetings. Perhaps one of the problems faced by the Richardsons and Burritt was that the range of their activities meant they were over-stretched. With Burritt back in the United States production must have become more and more difficult, so it was inevitable that it would cease soon after. What is clear is that the advocacy work undertaken by Henry Highland Garnet was not further developed after he went to Jamaica, so there is no apparent growth in the number of local associations. The problem facing the success of the free labour produce movement was identified early on by the Richardsons. The British Government's commitment to free trade meant that slave produce undercut the price of free labour produce. This made it very difficult for those who agreed that they should boycott slave goods, but whose low and erratic incomes made it difficult to afford the more expensive free labour produce. The broader anti-slavery campaigning, however, enabled a much bigger section of British society to support the cause. This essay has provided a preliminary introduction to The Slave. A more in- 
depth study is required of the details of its contents and to the wider movements in which the Richardsons and Burritt were involved.

\section{Works Cited}

Adams, W. E. (1968): Memoirs of a Social Atom. New York: Augustus M. Kelley.

Ashton, Owen R. (1991): W. E. Adams: Chartist, Radical and Journalist (18321906), Whitley Bay: Bewick Press.

British Foreign \& Anti Slavery Society (1841): Minutes of the Proceedings of the General Anti-Slavery Convention Called by the Committee of the British \& Foreign Anti-Slavery Society, Held in London June 1840. London.

Burritt, Elihu (1852): Twenty Reasons for Total Abstinence from Slave-Labour Produce. London: J. Unwin.

Chapman, Maria Weston (1857): Report of the Twenty-Third National AntiSlavery Bazaar. 1856-7. Boston: J B Yerrinton \& Sons.

Chapman, Maria Weston et al. (1858): Report of the Twenty-Fourth National Anti-Slavery Festival. Boston.

Charlton, John (2008): Hidden Chains: The Slavery Business and North East England 1600-1865. Newcastle-upon-Tyne: Tyne Bridge Publishing.

Coffin, Levi (1872): Reminiscences. A Brief History of the Labors of a Lifetime in Behalf of the Slave, with the Stories of Numerous Fugitives, Who Gained Their Freedom through His Instrumentality, and Many Other Incidents. Cincinnati, $\mathrm{OH}$ : Western Tract Society.

Douglass, Frederick (1849): "Henry Highland Garnet," The North Star, 10.8.1849, online at: http://www.theliberatorfiles.com/category/ garnet-henry-highland (accessed on 17.3.2009)

Douglass, Frederick (1855): My Bondage and My Freedom. Part 1. New York.

Ladies Emancipation Society (1838-1854): Ladies Negro Friend \& Emancipation Society for Newcastle-upon-Tyne. Minute Book Newcastle: Tyne \& Wear Archives. 3744/389.

Midgley, Clare (1992): Women against Slavery. The British Campaigns 1780-1870. London: Routledge.

Midgley, Clare (1995): "Women Anti-Slavery Campaigners, with Special Reference to the North East," in: North East Labour History 29, 19-39.

O'Donnell, Elizabeth A (2009): “'There's Death in the Pot!' The British Free Produce Movement and the Religious Society of Friends with Particular Reference to the North-East of England," in: Quaker Studies 13 (2), 184-204.

Poulter, Emma (2008): In Greater Manchester, online at: http://www.revealing histories.org.uk/ingreater-manchester-economics (accessed on 17.3. 2009)

Richardson, Anna (1859): Little Laura, the Kentucky Abolitionist. An Address to the Young Friends of the Slave. Newcastle-upon-Tyne: Thomas Pigg \& Co. 
Ripley, C. Peter, ed. (1985): The Blacke Abolitionist Papers. Vol 1. Chapel Hill \& London: University of North Carolina Press.

Sansbury, Ruth (1998): Beyond the Blew Stone. 300 Years of Quakers in Newcastle. Newcastle-upon-Tyne: Newcastle-upon-Tyne Preparatory Meeting.

Steel, John William (1899): A Historical Sketch of the Society of Friends "in Scorn Called Quakers" in Newcastle and Gateshead, 1653 - 1898. London: Headley Brothers.

Still, William (1872): The Underground Railway. A Record of Facts, Authentic Narratives, Letters, \&c, Narrating the Hardships Hair-Breadth Escapes and Death Struggles of the Slaves in their Efforts for Freedom, as Related by Themselves and Others, or Witnessed by the Author; together with Sketches of Some of the Largest Stockholders, and Most Liberal Aiders and Advisers, of the Road. Philadelphia: Porter \& Coates.

The Slave; His Wrongs and their Remedy (1851-56?): London \& Newcastleupon-Tyne. 1851-1856. British Library. Shelf mark P.P1046.ka.

Todd, Nigel (1991): The Militant Democracy: Joseph Cowen and Victorian Radicalism. Whitley Bay: Bewick Press.

Wright, H. C. (1846): Letter to Frederick Douglass and his Reply. 



\title{
A One-Sided Controversy: James Hunt and Africanus Horton on The Negro's Place in Nature
}

\author{
Arno Sonderegger
}

\section{Slave Trade and Slavery: Reification, Racism and Resistance}

Human enslavement might be as old as human history, understood in its most conventional form as having begun with the Neolithic revolution and, especially, with the invention of writing. At least, from then onwards it is possible to document the existence of stratified societies and systems of slavery across the globe. According to specialists, slavery seems to have been widespread, "almost ubiquitous". ${ }^{1}$ However, there are some peculiarities of slavery in modern times which help to distinguish them from more common ways of slavery, if not in kind at least in degree. First, there is the simple fact that Africans became the object of trade in such numbers that, after 1650 , there was an established tradition which tied together the status of a slave and black skin colour. ${ }^{2}$ Second, the dehumanisation experienced by slaves under colonial slavery was extraordinary as they were perceived and treated like chattel. In any case, they were considered inferior and ignoble beings. Their only value was in their manpower - in their role as, according to the biblical verse, "hewers of wood and drawers of water." 3 Together reification and racism were at work in producing a stereotyped image of Euro-African relations that, at the same time, allowed for both degrading the African

1 Walvin (2006), 11

2 See Davidson (1994), 43, 57-59.

3 Joshua 9:23. This phrase reappeared time and again in the colonial and travel literature of the $19^{\text {th }}$ century, often without any reference to its biblical origin or to the curse on Noah's grandson Canaan, son of Ham, described at some length in Genesis 9:18-27. 
('heathen' and 'black') and upgrading the European ('Christian' and 'white'). ${ }^{4}$ Clearly, these processes of imagining the 'other' and dealing with men culturally distinct from oneself became embedded in relations of power, violating both the humanity of those enslaved and those enslaving.

A third characteristic of modern slavery is the resistance it provoked - a transnational pressure movement previously unknown in human history whose offshoots are still active today. ${ }^{5}$ It was not until the late $18^{\text {th }}$ century that concerted efforts of men and women of European, African and diasporic origin, arguing and protesting against slavery, grew in influence and eventually became politically effective. The transatlantic slave trade came to be considered illegitimate towards the end of the $18^{\text {th }}$ century at a time when it reached its quantitative peak and was finally declared illegal by the British parliament in 1807. Alongside the abolition of the transatlantic slave trade, the emancipation of the slaves in imperial and, as regards the former North American colonies, ex-colonial spheres was a second important agenda of the anti-slavery movement. However, the fight against colonial slavery took many more years and was finally attained in the British colonies in the late 1830s and in the French territories in 1848. In the United States of America the overall emancipation of Blacks was only achieved in the course of a bloody civil war (1861-1865). ${ }^{6}$

After the British and French emancipation acts of the 1830s and 40s, the concern and strategies of abolitionists - since 1839 organised in the British and Foreign Anti-Slavery Society and similar institutions, for instance, the Aborigines Protection Society - were emphatically directed, among other regions of the globe, towards African affairs. Thomas Fowell Buxton's The African Slave Trade set this train of thought in motion, ${ }^{7}$ and the Niger Expedition of 1841 car-

4 The literature on racism in general and racism in colonial contexts in particular is extensive. Useful reflections are, from Africanist and historical points of view, Hallett (1976), Boahen (1987), Cooper/Stoler (1997), Adeleke (1998), Cooper (2005); from a historically informed sociological perspective, Hund (2006, 2007) and Wallerstein (2006); literary studies and philosophy offer another set of important insights, see, for instance, Mudimbe (1988), (1994), Appiah (1993), Achebe (2000), Pallua (2006).

5 See Miers (2003).

6 The historical literature on the slave trade and abolitionism is voluminous; discussions of this topic and relevant references may be found in Sonderegger (2008b) and (2009b).

7 Buxton (1839/1838). 
ried out "with the sanction of Her Majesty's Government" was a clear signal of the influence abolitionists now had on British imperial policy. More than ever before, conditions in Africa attracted the attention of abolitionists and policy makers. Their views on African realities, however, were extremely blurred and biased. This, of course, was due to Eurocentric attitudes on their side taking for granted the superiority of Christian religion and civilisation as well as their right and duty to intervene in the name of human progress and improvement. ${ }^{9}$ Sometimes even opponents of slavery joined in the racist chorus doubting not only Africans' capability to develop civilisation, as its advocates did, but their humanity altogether. ${ }^{10}$ Thomas J. Hutchinson (1820-1885) who became honorary secretary of the Church Missionary Society in the early $1870 s,{ }^{11}$ for instance, wrote in 1861: "To attempt civilizing such a race before they are humanized, appears to me beginning at the wrong end. [...] I fear ages must elapse before any educational principle in its simplest form can produce an amendment on temperaments such as they possess." ${ }^{12}$ In those circumstances the evils of the so-called 'African slave trade' as well as the 'Oriental slave trade' in North and East Africa became catchwords and trademarks which helped abolitionists to attain popular mass support but, at the same time, made them a medium for channelling and deepening colonial ambitions. It was not by chance that the notorious 'scramble for Africa' at the end of the $19^{\text {th }}$ century was legitimised by referring to the necessity of ending slavery and the slave trade within Africa. ${ }^{13}$

\section{Fields of Conflict: Abolition, Mission, and Race}

Both anti-slavery and missionary efforts which since the late $18^{\text {th }}$ century had shaped British policy and public opinion to a high degree came under severe attack in the second half of the $19^{\text {th }}$ century. The failure of abolitionist strategies for Africa to end slavery by

8 Schön/Crowther (1842), title page.

9 Barth/Osterhammel (2005), Wallerstein (2006), Sonderegger (2008a), 257-434, Sonderegger (2008b), 100-102.

10 Sonderegger (2009a), (2009b).

11 Grau (2008), 74.

12 Hutchinson (1861), 340.

13 Boahen (1987), Wirz (2000), Miers (2003), Sonderegger (2009b). 
means of 'legitimate trade' as well as the difficulties of missionary work in Africa cannot explain the change of mind which in the course of the 1860s became prevalent among those interested in African affairs, for missionary endeavours continued and "industrial missions run by skilled agents of African descent" 14 to develop natural resources and legitimate trade were still considered a promising strategy by those organised in the British and Foreign Anti-Slavery Society, the Aborigines Protection Society and the newly founded African Aid Society (1860). Indeed, from its very beginnings in the late $18^{\text {th }}$ century neither the anti-slavery movement nor the Christian missionary societies had been without critics. Slave traders and advocates of colonial slavery vehemently criticised the abolitionist agenda, and not all of them liked the idea of proselytising those whom they considered to be 'born slaves'.

Nevertheless, around the middle of the $19^{\text {th }}$ century an important discursive change became manifest. This change was rooted in the debate on 'race' which had been discussed in terms of monogenesis versus polygenesis since the $18^{\text {th }}$ century, but now the Janus face of both a vigorously renewed racial science and the Darwinian challenge took on a new and quite contemporary meaning. The 1860s were a period "[...] of immense ferment, in which politicians, churchmen, scientists and novelists did battle over the meaning of new conceptions of race, natural selection and evolution. These battles were far from merely intellectual exercises: they were also struggles for authority." 15

This can be illustrated by two writers, a European and an African, both dealing with the question of "the negro's place in nature": James Hunt (1833-1869) and Africanus Horton (1835-1883). Struggles for authority, however, happen in peculiar circumstances. Besides the wider historical situation already sketched, it is the institutional frame of those who spoke, wrote and read about Africa that is of importance. Figure 1 shows the relations of the 'professional bodies' and gives some hints as to the underlying ideological dividing lines responsible for the separation of the Ethnological Society of London (ESL) and the Anthropological Society of London (ASL) which lasted for nearly a decade. 
Figure 1: The institutional development of British Anthropology in the 19th century in relation to main protagonists and ideological frames of reference

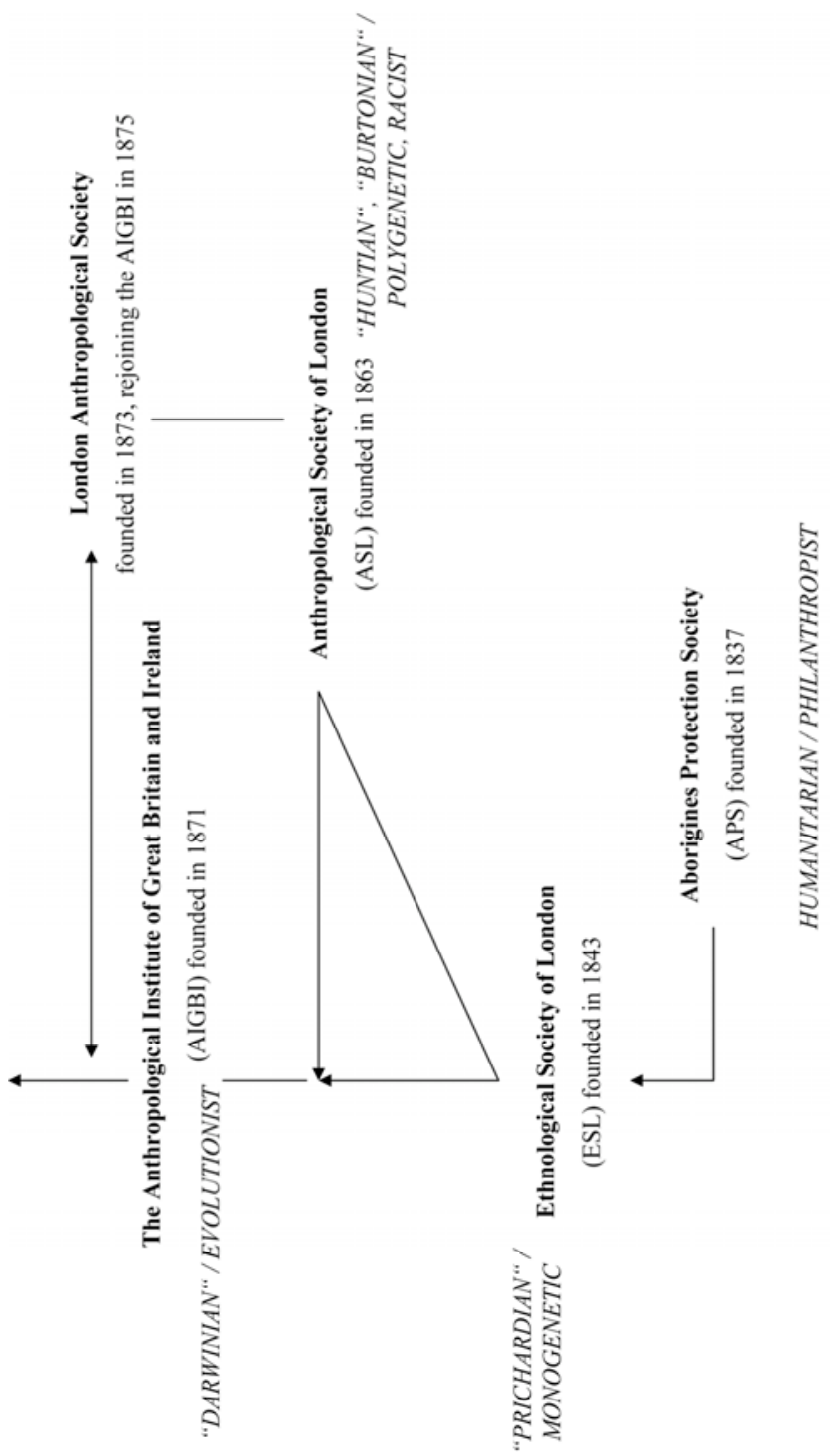

Sources: Stocking (1971), Stocking (1991), 242-257, Gaillard (2004), 1. 
It names a few prominent individuals - Thomas Henry Huxley (1825-1895) and Charles Darwin (1809-1882) representing the moderate position in the debate on 'race', while James Hunt and Richard Francis Burton (1821-1890) put forward the most radical racist opinions. Africanus Horton does not appear in Figure 1 because he did not play any role in this institutionalising process. This might be due to the fact that, in the 1860s, he no longer lived permanently in England but served the British West India Regiment at various posts along the west coast of Africa. However, it might have had to do with his being African as well.

\section{James Hunt and the 'Anthropologicals' on Race and Slavery}

Early in his life, James Hunt (1833-1869) followed in his father's footsteps, becoming a renowned speech therapist. Stammering and Stuttering, their Nature and Treatment was his first book published when he was only in his early twenties. ${ }^{16}$ Hunt joined the Ethnological Society of London in 1854 because of his interest in the difference of 'races'. ${ }^{17}$ That learned society had developed in 1843 as a separate body from the Aborigines Protection Society, "an essentially philanthropic organisation." 18 In contrast, the new body intended to concentrate essentially on descriptive, not on humanitarian concerns. However, missionary and anti-slavery issues were kept on the agenda as most members took for granted the original unity of mankind and some sentiment of Christian brotherhood. This was not in line with Hunt's views. Being energetic but quite unpopular within the Ethnological Society, he founded the Anthropological Society of London in 1863 - "endeavouring to found a new science [...] a science of Man or Mankind."19 In practice, however, Hunt's understanding of anthropology was quite narrow - limited to physical anthropology and consequently he "[...] promoted the society as a vehicle for a new kind of racial science [...]. Hunt rejected the monogenetic account of human evolution associated with the older Ethnological

16 Hunt (1863a). First published in 1854, this treatise was reprinted several times during Hunt's lifetime. The last edition known to me dates from 1967.

17 See Brock (2004)

18 Stocking (1971), 386.

19 Hunt (1864a), 2. 
Society, and was far more pessimistic about the prospects for the improvement of 'savage races'." 20

With regard to the different specialities of research Hunt declared as the society's objective, "[...] it is our object and desire to see them all united under one great science." 21 Obviously, his ambitions were scientifically imperialistic, and his imperialism was directed against an older British tradition of research as evident in the work of James Cowles Prichard ${ }^{22}$ and the Ethnological Society of London. Prichardian ethnology was comparative in perspective. It relied on ethnography, physical anthropology as well as linguistics. Unlike the naïve positivism of the later 'anthropologicals' it was well aware of the complexities of human life and the relevance of cultural differences, and accordingly its methods did hardly resemble the naturalistic reductionism so typical for both 'Huntian' and post-Darwinian anthropology. With regard to the question of human origin, Hunt's sympathy was with polygenism, notwithstanding his numerous remarks of being disinterested in such speculations. His far-reaching 'scientific' ambitions clearly went hand in hand with specific political opinions. For instance, he rhetorically asked himself,

[...] do I exaggerate when I say that the fate of nations depends on a true appreciation of the science of anthropology? Are not the causes which have overthrown the greatest of nations to be resolved by the laws regulating the intermixture of the races of man? Does not the success of our colonisation depend on the deductions of our science? Is not the composition of harmonious nations entirely a question of race? Is not the wicked war now going on in America caused by an ignorance of our science?23

Evidently Hunt believed in the existence of 'races' as well as in the importance of 'race'. What mattered most to him was therefore not so much whether human beings were of one or of many origins but simply the claim of profound racial differences setting European men apart and above other humans. Black Africans were the subject he most elaborately dealt with in this regard.

Hunt voiced his ideas On the Physical and Mental Characters of the Negro for the first time in public at the meeting of the British Asso-

20 Driver (2001), 96-97.

21 Hunt (1864a), 6.

22 Prichard (1836-47).

23 Hunt (1864a), 16. 
ciation for the Advancement of Science at Newcastle in 1863. According to James Hunt, it "[...] was received with such loud hisses that you would have thought the room had nearly been filled with a quantity of Eve's tempters instead of her amiable descendants." 24 According to a biographer, his speech "[...] was met with hisses and catcalls." 25 According to the minutes of this event printed in The Anthropological Review, however, the reactions seem to have been very matter-of-fact. ${ }^{26}$ The same paper presented to the ASL in November 1863 was approved of by the "young dilettante traveller"27 William Winwood Reade (1838-1875) and zoologist-anthropologist Charles Carter Blake (1840-1887) but critically rejected by a Reverend Dingle and Thomas Bendyshe (1827-1886), the last one doing so on Darwinian grounds. ${ }^{28}$

In obvious reference to Thomas Henry Huxley's recently published Man's Place in Nature (1863), Hunt's anti-Darwinist pamphlet was published under the title On the Negro's Place in Nature the same year. An American edition with a slightly different heading followed in 1864 and was reprinted in 1866, then as "No.4" in a series significantly called "Anti-Abolition Tracts". 29 The American editions of Hunt's statements on 'the Negro' had direct political implications, for it was only in the course of the American Civil War (1861-1865) that slavery in the American South was legally abolished. Even after the emancipation act there remained a group of fierce opponents unwilling to accept the liberation of former slaves. Hunt's remarks make it abundantly clear that he supported the Confederate States and the slaving system of the American South. To him, the natural role of Africans was that of slaves, and the enslavement of Africans by Europeans was the means of their "domestication". ${ }^{30}$ The use of

\footnotetext{
24 Hunt (1863c), v.

25 Brock (2004).

26 See Anonymous (1863), 387-390.

27 Fyfe (1993), 334.

28 Anonymous (1864), on Reade's comments see p. xviii ff., on Carter Blake's comments see p. xxiii ff., on Dingle's comments see p. xxix ff., on Bendyshe's comments see p. xxxiv ff. 29 Hunt (1863c, 1864b, 1866).

30 Hunt approvingly quoted the notorious American racist Josiah C. Nott to this end, "In Africa, owing to their natural improvidence, the Negroes are more frequently than not a half-starved, and therefore half-developed, race; but when they are regularly and adequately fed, they become healthier, better developed, and more humanised. Wild horses, cattle, asses, and other brutes are greatly improved in like manner by domestication; but
} 
such zoological vocabulary was quite appropriate as Hunt rejected the African's ability to civilise himself or be civilised by others out of hand, ${ }^{31}$ he even doubted his humanity, classifying the "Negro" nearer to the ape than to the European..$^{32}$

According to Hunt there were deep-rooted physical, mental and moral differences dividing Europeans from Africans and making the latter much inferior to the former. Although Hunt declared "that I understand by Negro, the dark, woolly-headed African found in the neighbourhood of the Congo river" and "that my remarks will be confined to the typical woolly-headed Negro," 33 his use of literature and measurements - regardless of provenance - make it abundantly obvious that his remarks were targeted on all Africans and African Americans alike (see Figure 2). "The skin and hair are," he wrote, "by no means the only characters which distinguish the Negro from the European, even physically; and the difference is greater, mentally and morally, than the demonstrated physical difference." 34 Most of his paper, then, consists of a confused 'demonstration' of such claimed differences, trying to legitimise his views of a racial hierarchy. Regarding physical differences Hunt relied heavily on the measurements of Pruner Bey, i.e. Franz Ignaz Pruner (1808-1882), a German physician who made a career in Egypt and figured prominently in the Société d'Anthropologie de Paris in the 1860s. ${ }^{35}$ In fact, Hunt's translation of Franz Pruner's Mémoire sur les nègres (1861), often inserted in form of extensive footnotes, constitutes perhaps half of Hunt's treatise. Other sources he used frequently were the writings of American anatomists and pro-slavery activists, like Samuel Morton (1799-1851) or Josiah C. Nott (1804-1873), 36 as well as contemporary travel writings.

neither climate nor food can transmute an ass into a horse, or a buffalo into an ox." (Hunt [1863c], 32-33).

31 Hunt (1863c), 27-31 (see Figure 2).

32 Hunt (1863c), 51-52. On pages 43-46 some travellers are quoted at length who described Africans in animalistic, ape-like terms.

33 Hunt (1863c), 2.

34 Hunt (1863c), 4.

35 Hirsch (1888), 675f., Wormer (2001), 747f. Less often Hunt also referred to the founder of the Société d'Anthropologie de Paris, Paul Broca (1824-1880), and to Carl Vogt (18171895), a Swiss anatomist whose Lectures on Man were translated and published by Hunt in 1864.

36 On the racism of Morton, Nott and other American writers in the $19^{\text {th }}$ century as well as on Broca's racial thinking see Gould (1981), chapters 2 and 3. 
Most prominently in this respect figured Richard Francis Burton's Wanderings in West Africa, published anonymously in 1863. Burton officiated as Vice-president of the Anthropological Society, and it was to him that Hunt dedicated his treatise with the words,

You are, as all Anthropologists know, one of the few men who are competent to give any decided opinion as to the value of my communication. We have had plenty of African travellers, but there is perhaps no other man living who, by previous education and study, is better able than yourself to paint the Negro and other African races as they exist, regardless of what we may consider should be their state. ${ }^{37}$

Burton's belief in the natural inferiority of Africans was quite as much developed as Hunt's. "I believe in the inferior genesis of the negro," he apodictically wrote, "and in his incapability of improvement, individually and en masse." 38 That Burton's own descriptions of developments of individual Africans as well as social, cultural and political circumstances in Africa continually contradicted this statement did not hinder him to propose it and claim its truth. Adopting an immunisation strategy Burton, like racists of all times, proclaimed the existence of a hidden reality allegedly much more important than any visible signs of evidence. In the same vein Hunt, for instance, wrote

There is a peculiarity in the Negro's voice by which he can always be distinguished. This peculiarity is so great that we can frequently discover traces of Negro blood when the eye is unable to detect it. No amount of education or time is likely ever to enable the Negro to speak the English language without this twang. Even his great faculty of imitation will not enable him to do this. ${ }^{39}$

One of the reasons for the contradictions so evident in both Burton and Hunt might be their self-styled positioning at the margins of accepted gentlemanly behaviour. "Hunt and the leading 'anthropologicals' violated the canons of behavior appropriate to a scientific society composed of respectable gentlemen. The inner clique of the Anthropological Society [...] called itself 'The Cannibal Club' [...],"

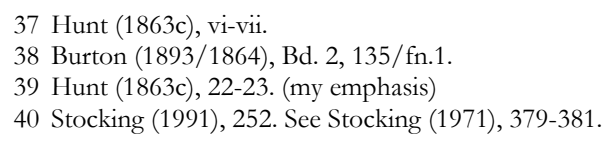


and they behaved accordingly. Their choice of topics - "cannibalism, polygamy, phallic worship, circumcision and infibulation" 41 - as well as the style in which they talked and wrote about them was commonly regarded inappropriate, if not frivolous or even pornographic. ${ }^{42}$

What distinguished the 'anthropologicals', therefore, was not simply a call to extend the dominion of science to man itself, but to do so on the basis of a particular style of racial and sexual politics. The anthropologicals were $[\ldots]$ enthusiastic about embracing the idea of racial difference; $[\ldots]$ They regarded the refusal of their critics to concede the innate character of the differences between races as not only unscientific but unmanly. In this context, the exclusion of women from their meetings was of critical importance. The new 'science of man' was, they argued, the preserve of men; open enquiry demanded closed rooms. ${ }^{43}$

Evidently then, Hunt, Burton and their colleagues felt threatened. Unsure in their manliness as well as in their class position, they found a means of reassurance in a revolting pose. Their 'revolution' against the 'ethnologicals' by founding a society of their own and setting the course for a new tone in ethnographic and anthropological discourse provided them with an institutional base. They fully embraced the idea of their own racial superiority and propagated it successfully, attracting a wide membership. ${ }^{44}$ The feeling of racial superiority was mirrored in frequent misogynic, sexist remarks, as apparent, for instance, in Hunt writing, "There is no doubt that the Negro brain bears a great resemblance to a European female or child's brain, and thus approaches the ape far more than the European, while the Negress approaches the ape still nearer." ${ }^{25}$ (see Figure 2)

To Hunt it was inconceivable that women's abilities might resemble those of men, given comparable opportunities. Equally unthinkable seemed the idea Africans could perform alike. With regard to the developments made by free Africans according to European standards both in America and on the West Coast of Africa, in Sierra 
Leone and Liberia, ${ }^{46}$ Hunt either ignored their existence or claimed that they have been advanced by the infusing of "European blood".

Figure 2: Imagining Africa and Africans according to James Hunt and the "anthropologicals": claims as to their inferior, brutish and slavish nature
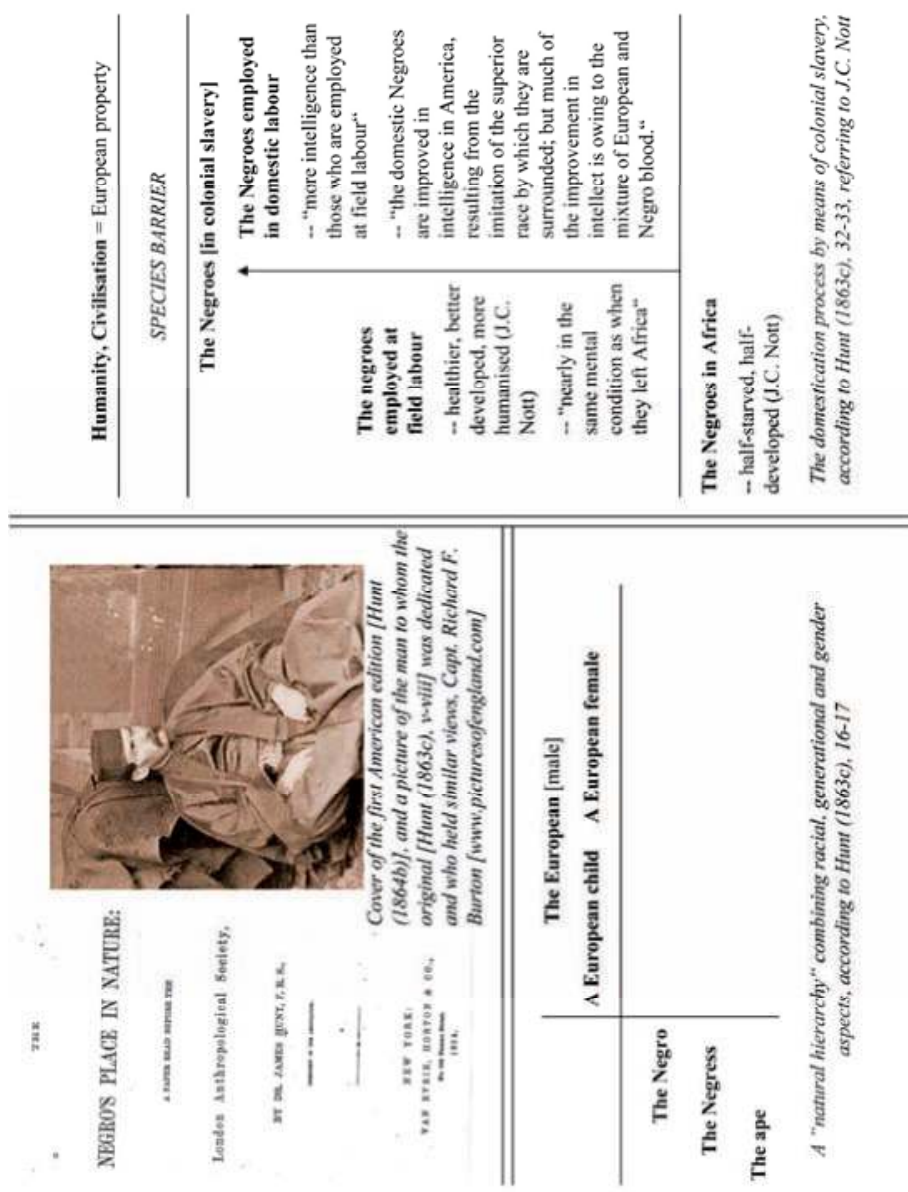

Sources: Hunt (1864b); Hunt (1863c), v-viii, 16-17, 32-33; bttp://wmw.picturesofengland.com. 
In the Southern States of North America, in the West Indies and other places [...] it is simply the European blood in their veins which renders them fit for places of power, and they often use this power far more cruelly than either of the pure blooded races. It has been affirmed that occasionally there are seen Negroes of pure blood who possess European features: but I believe such not to be the fact $[\ldots] .{ }^{47}$

Hunt even went so far as proposing a global prehistoric migration out of Europe strikingly similar to the notorious 'Hamitic hypothesis' of later years. ${ }^{48}$ Without giving any evidence supporting his claim, he wrote,

We now know it to be a patent fact that there are races existing which have no history, and that the Negro is one of these races. [...] like all inferior races, there has been little or no migration from Africa since the earliest historical records. The European, for ever restless, has migrated to all parts of the world, and traces of him are to be found in every quarter of the globe. Everywhere we see the European as the conqueror and the dominant race, and no amount of education will ever alter the decrees of $\mathrm{Na}$ ture's laws. ${ }^{49}$

Obviously, Hunt was no friend of educatory efforts. He dogmatically denied "[...] that the Negro only requires early education to be equal to the European" 50 and claimed instead, against every evidence available, "With the Negro, as with some other races of man, it has been found that the children are precocious: but that no advance in education can be made after they arrive at the age of maturity, they still continue, mentally, children. [...] the reflective faculties hardly appear to be at all developed." 51

Although Hunt occasionally compared European women and, more often, children to Africans to emphasise their allegedly undeveloped character, he was quite intent on claiming an absolute, 'natural' dividing line between 'the' European and African (see Figure 2). That is why Hunt rejected Darwinism which argued for an under-

47 Hunt (1863c), 28-29.

48 See Sonderegger (2009a), $70 f$.

49 Hunt (1863c), 29-31.

50 Hunt (1863c), 27.

51 Hunt (1863c), 27. (my emphasis) This idea of the 'halted' development of 'savages' was quite commonly held in $19^{\text {th }}$-century racial thinking and it stayed alive throughout the colonial era. 
standing of man as part of the animated world genetically linked to all living species. In fact, Hunt fiercely opposed this revolutionary line of thought and stuck to his fixed race theory (see Figure 3).

Both Burton and Hunt opposed Christianity and frequently attacked missionary and anti-slavery proponents. Christopher Fyfe appropriately characterised Burton's Wanderings in West Africa as “[...] a gossiping travel-book, but invested with the prestige and authority its distinguished explorer-author commanded. Here, with cruel wit, he flayed Freetown [...], pouring scorn on missionaries and their pupils." 52 Except for the traveller's expertise, much the same could be said of Hunt, who granted the abolitionists that the transatlantic slave trade had been horrendous but still approved of colonial slavery, because, as he argued,

[...] I cannot shut my eyes to the fact that slavery as understood by the ancients does not exist out of Africa, ${ }^{*}{ }^{*}$ 'No man maltreats his wild brother so much as the so-called civilised Negro,' Hunt quotes Richard Francis Burton in the footnote] and that the highest type of the Negro race is at present to be found in the Confederate States of America. Far superior in intelligence and physique to both his brethren in Africa and to his 'free' brethren in the Federal States [...]. [...] Scientific men, therefore, dare not close their eyes to the clear facts, as to the improvement in mind and body, as well as the general happiness, which is seen in those parts of the world in which the Negro is working in his natural subordination to the European. ${ }^{53}$

Of course, the facts about colonial slavery and the "plantation complex" were quite contrary to the idyllic sketch drafted by Hunt on the basis of some American advocates of slavery. ${ }^{54}$ The image of a 'despotic Africa', so current since the late $18^{\text {th }}$ century, ${ }^{55}$ could still serve Hunt as a comfortable means to claim the worthlessness of life in Africa, thereby legitimising his pro-slavery standpoint.

Hunt was a master of contradictions, claiming scientific authority on the basis of alleged evidence but ignoring all evidence available

52 Fyfe (1993), 334.

53 Hunt (1863a), 54-55.

54 One of his sources, J.H. van Evrie, wrote the introduction to Hunt's American edition (1864b), 3-4, and probably Hunt's obituary in the New York. Weekly Day-Book, Nov. 6 $^{\text {th }}, 1869$ as well, reprinted in Anonymous (1870), 97. On colonial slavery see the short but masterful Curtin (1998).

55 See Sonderegger (2008a), 230-233, 244-256, 277-283, 309-398, 398-434. 
that contradicted his opinions. The final sentence of his pamphlet makes this abundantly clear. There he wrote, "it is only by observation and experiment that we can determine the exact place in nature which the Negro race should bold, and," he continued making even more evident his apodictic method, "that it is both absurd and chimerical to attempt to put him in any other." 56 To Hunt the "negro's place in nature" was evidently there where he wanted him to stay indefinitely: in, as he put it, "his natural subordination to the European." 57

\section{Africanus Horton on Race and Civilisation: An Outsider's Act of Resistance}

In 1868 a book subtitled $A$ Vindication of the African Race was published. Its author was a very distinguished man (see Image 1). Born to Igbo parents - originating in what is today South Eastern Nigeria - in the British crown colony of Sierra Leone, James Africanus Beale Horton spent five years $(1855$ - 1859) in England studying medicine. After his return to Africa Horton enlisted in the British army and served as a medical doctor. He worked at several posts along the western shores of the coast, from the Gambia to the Gold Coast, and even "visited Lagos". ${ }^{58}$ In short, he had first-hand knowledge of all the English territories of West Africa. In 1880 he quitted military service and started doing business in mining concessions. Shortly before his untimely death in 1883 he launched the Commercial Bank of West Africa that "attempted to supply credit facilities to West African traders." ${ }^{59}$ Africanus Horton was a man of both practical ambitions and intellectual gifts. Most of his European contemporaries, however, did appreciate neither the one nor the other. The only thing about Horton that was received with some interest on their side was his contribution to tropical medicine. ${ }^{60}$ His political writings were largely ignored or paternalistically absorbed. ${ }^{61}$

56 Hunt (1863c), 60. (my emphasis)

57 Hunt (1863c), 55.

58 Horton (1867), x.

59 Adi/Sherwood (2003), 88.

60 Shepperson (1969), x specified four medical publications by Horton: The Medical Topography of the West Coast of Africa; with Sketches of its Botany (1859); Physical and Medical Climate and Meteorology of the West Coast of Africa (1867); Guinea Worm, or Dracunculus, its Symptoms and Pro- 
208 A One-Sided Controversy

Image 1: James Africanus Beale Horton

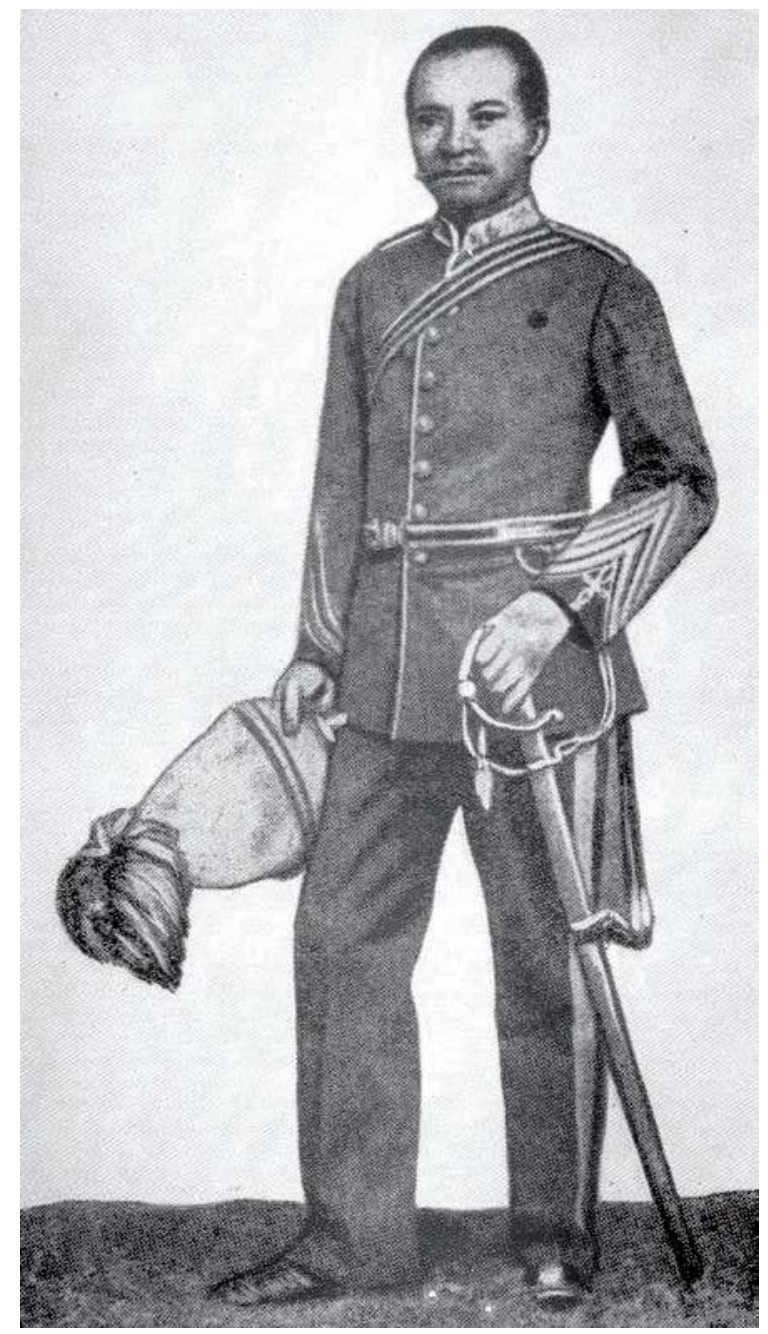

Source: Horton (1969) ii.

gress, Causes, Pathological Anatomy, Results and Radical Cure (1868); The Diseases of Tropical Climate and their Treatment (1874).

61 Ayandele (1979), 164-166, Fyfe (1992). 
There was some reason in such ignorance, for part one of Horton's West African Countries and Peoples contains a scientifically informed critique of Victorian racism. Horton called it The Negro's Place in Nature, in direct reference to Hunt's racist pamphlet of 1863. There, Horton referred directly to the Anthropological Society of London designating it

an association [...] to rake up old malice and encourage their agents abroad to search out the worst possible characteristics of the African, so to furnish material for venting their animus against him. [...] It would have been sufficient to treat this with the contempt it deserves, were it not that leading statesmen of the present day have shown themselves easily carried away by the malicious views of these negrophobists, to the great prejudice of that race. ${ }^{62}$

According to Horton, these 'anthropological negrophobists' were simply prejudiced and, from a scientific point of view, negligible. What made it necessary to deal with them was their influence on the thinking of those who were in the position to decide on British policies towards Africa. Horton explicitly mentioned politicians but he could have named missionaries as well, for even within the dominant body of missionary work in Sierra Leone - the Church Missionary Society - a more racialised tone had been emerging since the 1860s. Moreover, concerning his military promotion Horton's attainment was delayed on racial grounds. ${ }^{63}$

In his critique Horton relied in part on classical abolitionist writers, quoting Thomas Clarkson (1760-1846) and Wilson Armistead ( 1819-1868), but more frequently he made use of his scientific expertise and first-hand knowledge. Therefore, much of his text is, on the one hand, dedicated to a discussion of the physical and anatomical features allegedly typically African while, on the other hand, he demystifies European travellers' accounts. Christopher Fyfe gives an accurate summary of Horton's refutation:

With such empirical arguments Horton [...] only needed to quote a few passages from Carl Vogt's 'exuberant, ignorant eloquence' to reveal that Vogt knew nothing of Africa or of Africans. Burton, who did know Africa, he convicted of inconsistency and 
prejudice. The much-cited racial investigations of Pruner Bey, physician to the Khedive of Egypt, he showed to have been based on a few untypical physical specimens. He concluded that before scientists began pontificating about Africans, they must learn more about them $\left[\ldots . .{ }^{64}\right.$

Much the same criticism he directed against James Hunt:

[...] Horton convicted him of ignorance and prejudice. Hunt's ignorance was displayed by the second-hand, inaccurate evidence he used to make his case. His prejudice he displayed by his choice of authorities, including Burton, and his readiness 'to select the worst possible specimens, and make them typical of the whole African race,' but to display as the typical European 'the most perfect and model form'. ${ }^{65}$

In contrast to Hunt and Burton, Horton considered African's capacity for civilisation to be simply a matter of fact. He alluded to the British settlements on the west coast of Africa as undeniable evidence. Unlike them, he appreciated the missionary support for Sierra Leone and held Christianity in high regard. Contrary to Burton, Horton denied "that the Mohammedan religion, in all cases where Western Africa is concerned, should supplant that of Christianity," 66 declaring instead that

I, amongst a great many others, appreciate every European element that enters Western Africa, whether in the capacity of merchants or pioneers of civilization, or in that of missionaries; and whilst I hail their efforts, respect their talents, and revere the civilization they are capable of imparting, I will never permit any unjust abuse, any unfounded diatribe against the African race [...]. ${ }^{67}$

It is apparent, then, that Horton's concept of civilisation was modelled according to the European paradigm. What he wanted to implement in Africa was an 'Africanised' version of modernity. Emmanuel Ayandele's characterisation of Africanus Horton as a "prophet of modernization" outlines this very well. ${ }^{68}$ Still, although Horton rejected traditional African ways of life, his rejection was not

64 Fyfe (1992), 70.

65 Fyfe (1992), 64 quoting Africanus Horton in African Times, April 23, 1866. See Sonderegger (2002), 70-73.

66 Horton (1969/1868), vi.

67 Horton $(1969 / 1868)$, vii.

68 Ayandele (1979), 164. 
based in any alleged 'natural inferiority' but in their relative discrepancy to his developmental ideal.

In viewing the map of West Africa, and tracing out those political communities which are not due to the agency of more civilized politicians, we affirm that there are amongst them fixed and established Governments, although rude and barbarous; that the obedience to the supreme power in many cases is implicit, the right of property is enforced by abjudicature; and, although the power of the supreme head has been used with extreme despotism, as in Dahomey and Ashantee, yet still it is as truly a political Government as that of France or England. By nature the African is a social being, possessing the capacity of commanding and obeying, and that type of improvement which advances as the reason is cultivated, which are the essential elements both of a political Government and a political community; and therefore Africans bear no relation whatever to those gregarious species of animals - apes, monkeys, \&c. - to which some fantastic writers have likened them. ${ }^{69}$

To Horton 'inferiority' was not a matter of a fixed racial marker but a matter of opportunity. Human societies and cultures, he held, were changeable entities and, as might be seen in historical perspective, they have been changing continuously in time. ${ }^{70}$ Given the evident dynamism of his views on 'race' and cultural 'development', the absence of any reference to the intellectual Darwinian revolution of the 1860s in Horton's account is striking. At least the ignorance was mutual, as will be shown below.

\section{Evolutionary Thought and the Negro's Place in Nature}

During the 1860s James Hunt and some other prominent members of the Anthropological Society were in continuous critical engagement with the older organisation from which they had separated in 1863: the Ethnological Society which comprised leading figures of the emergent evolutionary school of thought (see Figure 1). Both the anthropologicals' concern with a strongly racialised science claiming irreconcilable differences between human societies and the offending way in which they put forward their radical opinions set them

69 Horton (1969/1868), 3-4.

70 On his philosophy of history see Sonderegger (2002), 74-76. 
miles apart from those anthropological writers who were rising to much more enduring prominence in the course of the very same decade. By means of its theory of descent, the Darwinian revolution prepared the ground for considering 'the Other' in the perspective of socio-cultural evolution. Combined with the Malthusian principle of selection - still notoriously known in Herbert Spencer's phrase as the 'survival of the fittest' - Darwinism allowed for the reconciliation of two contradictory ideas: the belief in a single humanity as well as in elementary racial divides. Since then the universalist inclusion of all the people of the world into a single frame of reference (one humanity, monogenesis) was accompanied by a disruptive belief in gradual, but deep-rooted, racial differences between various peoples which might be overcome in time.

While Africanus Horton shared the belief in monogenesis, being a professing Christian, he had much less sympathy for both Darwinian theories of descent and natural selection, for they necessitated searching for distinguishing, 'specifying' traits and therefore inappropriately naturalised and fixed difference. ${ }^{71}$ True, their understanding of racial identity was less fixed than that of the 'anthropologicals' who declared Africans to be mere animals, but the evolutionists still opined it would take aeons to civilise those whom they too considered inferior types of men. Horton's views were quite different: he sought to show the similarities and commonness of all humans, to give due credit to the attainments of Africans in history and in the contemporary world, and to request equal rights as well as the self-government of the British possessions on the west coast of Africa by 'civilised' men of African descent. Therefore his silence with regard to the Darwinian revolution of the 1860s comes as no surprise. But why did the evolutionists who otherwise showed a keen interest in foreign parts of the world, including Africa, not react to Africanus Horton's first-hand expertise? An answer to this question necessitates a short digression on the evolutionists' ideas on race and civilisation.

Thomas Henry Huxley, notorious for his reputation as 'Darwin's bulldog', was the central figure in the academic reorientation taking shape in the 1860s and early 70 s in both of his roles as engaged academic entrepreneur and prolific writer. It was mainly on his 
initiative that the ESL and ASL merged in 1871 to build a unified institution dedicated to anthropology now understood as the study of mankind in all its aspects: the AIGBI. ${ }^{72}$ (See Figure 1) Following the publication of Charles Darwin's Origin of Species in 1859, Huxley was the first who interpreted human and primate forms of life in the light of the Darwinian theory of evolutionary descent which supposed a transmutation of species by way of natural selection. His Man's Place in Nature (1863) was widely recognised and, although not well received by everyone, proved to be very influential. Therein, Huxley evidently distinguished "Man" from "Ape" as two separate orders. To argue this point Huxley asked his readers to put themselves in the place of an alien. They should consider themselves "scientific Saturnians" 73 on a trip to earth.

There would remain then, but one order for comparison, that of the Apes [...], and the question for discussion would narrow itself to this - is Man so different from any of these Apes that he must form an order by himself? Or does he differ less from them than they differ from one another, and hence must take his place in the same order with them?

$[\ldots]$ and if we found that these [characteristics] were of less structural value, than those which distinguish certain members of the Ape order from others universally admitted to be of the same order, we should undoubtedly place the newly discovered tellurian genus with them. ${ }^{74}$

Regarding descent, however, it seemed evident to Darwinians that, despite "Man" being defined as a "family apart", 75 he is genetically related to the "Man-like apes." "Without question, the mode of origin and the early stages of the development of man are identical with

72 Stocking (1971), 382-387 and (1991), 248-262. James Hunt's sudden death in late 1869 surely facilitated this 'reunification' process. Richard Burton and other 'anthropologicals' separated again, founding the short-lived London Anthropological Society (1873-1875). However, their project came to an end and they rejoined the AIGBI. There might be assumed that some of the racial thinking pioneered by the ASL had been successfully introduced into the AIGBI and, therefore, no special forum was needed anymore.

73 Huxley (2001/1863), 71.

74 Huxley (2001/1863), 72.

75 Huxley (2001), 106.

76 Huxley (2001), 106 distinguished between "Man-like apes" - "the Gorilla and the Chimpanzee" - and "the lower apes", and stated "that the structural differences which separate Man from the Gorilla and the Chimpanzee are not so great as those which separate the Gorilla from the lower apes." See Huxley (2001), 72. 
those of the animals immediately below him in the scale: - without a doubt, in these respects, he is far nearer the Apes, than the Apes are to the Dog."' 77 Based on serious anatomical studies Huxley spoke of 'Man' in his entirety, not distinguishing between what in the terms of the days were designated 'races'. He even reacted in strong words to Hunt's allegations regarding the 'negro' as a distinct species, calling this point of view a "scandalous absurdity" and "nonsense". ${ }^{78}$

Huxley narrowed most of his work to physical anthropology but occasionally he emphasised "the great gulf which intervenes between the lowest man and the highest ape in intellectual power." 79 From such phrasings it becomes evident that Huxley still distinguished between men, and he did so according to the conventions of his time. His "lowest man", also referred to as 'archaic man', 'primitive man' or 'savage man' by him and other writers, bore a striking resemblance to the stereotypic image of the African prevalent in Victorian discourses. ${ }^{80}$ Africans were generally considered inferior beings. To Huxley, Darwin and the socio-cultural evolutionists as well as missionaries and abolitionists this was an 'unhappy state' resulting from unfavourable environmental causation. To their opponents racists and pro-slavery advocates like Hunt and Burton - this was simply the 'state of nature', the just and inescapable expression of an inborn inferiority. Both groups, however, accepted the alleged inferiority as a given fact.

Most evolutionists "defend[ed] the idea of the unity of the human race." 81 (See Figure 3) Their concept of a straight-lined evolutionary progress, however, still allowed for distinctions between various human groups, put forward in a naturalising language and ranked hierarchically according to the steps made, or not made, on the ladder of progress. The "evolutionists sketched out a notion of linear human evolution, in which so called 'primitive' societies constituted a stage anterior to their own, modern society." 82 Huxley actually did so in the last paragraphs of his book where he proclaimed,

77 Huxley (2001), 67. (my emphasis)

78 Professor Huxley, on The Structure and Classification of the Mammalia, lectures delivered at the Royal College of Surgeons; quoted in Taylor (1864), 12.

79 Huxley $(2001 / 1863), 103$.

80 See Pallua (2006), 81-91 for a vivid account, both on Darwin and Huxley, as well as Kuper (1988), Stocking (1991).

81 Gaillard (2004), 8.

82 Gaillard (2004), 8. 
[...] that they [the most ancient Races of men] fashioned flint axes and flint knives and bone-skewers, of much the same pattern as those fabricated by the lowest savages at the present day, and that we have every reason to believe the habits and modes of living of such people to have remained the same from the time of the Mammoth and the tichorhine Rhinoceros till now [...]. ${ }^{83}$

Figure 3: The progressive Darwinian view of the relation of Man and the animal world versus the anti-Darwinist Huntian racial divide.

a) Taxonomy, descent and evolutionary progress, combined according to Huxley

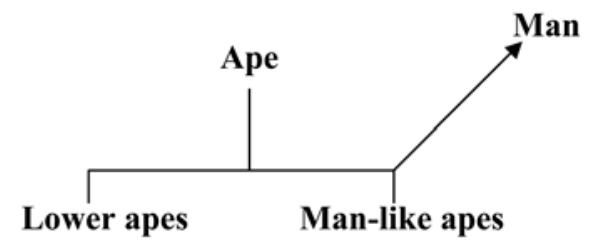

b) A "natural hierarchy" combining racial, generational and gender aspects, according to Hunt

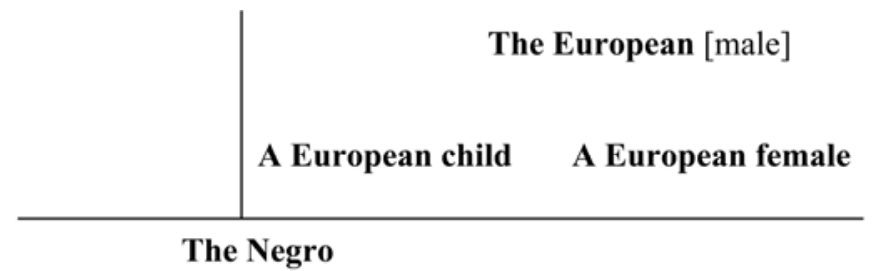

The Negro

The Negress

The ape

Sources: Huxley (1863), 71-72., 106; Hunt (1863c), 16-17.

In an evolutionist perspective they seemed to represent our earliest ancestors, sort of "living fossils" damned to die out, at least in the long run. Concerning those fitting neither the 'primitive' nor the 'modern' image an in-between stage was quick at hand. In his influ- 
ential Researches into the Early History of Mankind and the Development of Civilisation (1865), Edward Burnett Tylor put the traditional triad of "savagery, barbarism and civilization" in a developmental sequence. ${ }^{84}$ Mankind, it was now increasingly held, was progressing along these lines. While Social Darwinists' views, centring around the metaphors of a universal 'struggle for existence' and the 'survival of the fittest', had immediate political implications, it seems that most socio-cultural evolutionists did not consider them in their actual works but simply accepted, without further thought, the progressive tendency of evolution as fact. In any case, when Darwin published his own work on human history, The Descent of Man, in 1871, a Darwinian view on life had already attained broad currency among the educated, and within anthropology a progressive understanding of evolutionism was the ruling paradigm directing research for many decades to come.

\section{Conclusion}

The 'Darwinians' and evolutionists did, in some sense, pacify the discursive battles of the 1860s which centred around the role of both religious and secular missionary activity, as well as slavery, the slave trade and the "negro's place in nature". However, they did so in a most problematic way combining paternalism with racism. Understandably, this was quite disturbing to people like Africanus Horton who had successfully emancipated themselves according to European standards and now requested full-fledged self-determination. To them the factual sobriety of the evolutionists was easily recognisable as the outcome of a peculiar setting and discourse of power. With regard to religious and civilising missions - obviously pressing issues for Africans - most Darwinians and evolutionists behaved indifferently, virtually 'agnostically'. ${ }^{85}$ They took missionary as well as colonial activities simply for granted, nothing to criticise and nothing to embrace. The same attitude which clearly supported the imperial status quo was shown towards other crucial issues. Although neither Darwin nor Huxley were in sympathy with slavery, none of them made pronounced statements on this topic. Regarding 'race' both

84 Gaillard (2004), 15; Tylor (1865); see Stocking (1991).

85 Interestingly the term "agnosticism" was coined by Thomas Huxley, Huxley (2001), ix-x. 
Darwin and Huxley were all-embracing in their approach claiming they could integrate the best of both schools of thought - the polygenetic and the monogenetic - in their evolutionary synthesis. ${ }^{86}$

Whether primeval man, when he possessed but few arts, and those of the rudest kind, and when his power of language was extremely imperfect, would have deserved to be called man, must depend on the definition which we employ. In a series of forms graduating insensibly from some ape-like creature to man as he now exists, it would be impossible to fix on any definite point where the term 'man' ought to be used. But this is a matter of very little importance. So again, it is almost a matter of indifference whether the so-called races of man are thus designated, or are ranked as species or subspecies; but the latter term appears the more appropriate. Finally, we may conclude that when the principle of evolution is generally accepted, as it surely will be before long, the dispute between the monogenists and the polygenists will die a silent and unobserved death. ${ }^{87}$

This proved to be a momentous fallacy because most contemporaries regarded "primeval" and "primitive" to be synonyms. The naturalising diction used made the evolutionists indifferent to the cultural nuances and blind to the political implications of linguistic use. To actually living humans, however, to be "ranked as species or subspecies" or simply as "man" did make a difference all too real. Africanus Horton knew this only too well.

An all-embracing, rhetorically powerful "European universalism" 88 marks the evolutionists as men of their times. This bias might explain why the evolutionists saw no necessity at all to inform themselves at first hand - that is by talking and listening to Africans or reading the published works of educated Africans. To them, only the accounts of European men seemed to be reliable sources. ${ }^{89}$ The evo-

86 Darwin, for instance, wrote, "Even the most distinct races of man are much more like each other in form than would at first be supposed;" but immediately continued that "certain negro tribes must be excepted [...]." (Darwin [2007/1871], 146.) While Darwin's rejection of polygenism (145-158) was convincing, his ambivalent attitude towards 'savages' became quite clear in his remarks On the Extinction of the Races of Man (158-167); see also Pallua (2006), 82-83, 86-91.

87 Darwin (2007/1871), 157. (my emphasis)

88 Wallerstein (2006).

89 The references in Darwin (2007/1871) make this abundantly clear. They include travellers - like Burton - as well as long time residents: missionaries, traders, soldiers and colonial administrators. 
lutionists belonged to an intellectual elite well adapted to its cultural environment and, although liberal in political orientation, they strictly adhered to Victorian norms and values. Socialised in such a manner, taking for granted their own superiority, they too were no longer prepared to listen to Africans - not even to an African scientist. In spite of Africanus Horton's medical learning and unparalleled first-hand knowledge of West African countries and peoples, his work was not appreciated by the anthropological establishment. At least concerning the ignorance as well as their 'modestly' phrased racism the evolutionists were not so different from radical racists like James Hunt and his colleagues. Unfortunately their mix of racism and paternalism made a rather enduring impact.

\section{Works Cited}

Achebe, Chinua (2000): Home and Exile. New York: Anchor Books.

Adeleke, Tunde (1998): UnAfrican Americans. Nineteenth-Century Black Nationalists and the Civilizing Mission. Lexington: The University Press of Kentucky.

Adi, Hakim/Sherwood, Marika (2003): Pan-African History. Political Figures from Africa and the Diaspora since 1787. London, New York: Routledge.

Appiah, Kwame Anthony (1993/1992): In My Father's House. Africa in the Philosophy of Culture. Oxford: Oxford University Press.

Anonymous (1863): "Anthropology at the British Association. Dr. Hunt on the Negro," in: The Anthropological Review I (3) November, 386-391.

Anonymous (1864): “Dr. James Hunt on the Negro`s Place in Nature," in: The Anthropological Review, and Journal of the Anthropological Society of London (IV) February, xv-lvi.

Anonymous (1870): "Death of the Best Man in England," in: Anthropological Review 8 (28) January, 97.

Ayandele, Emmanuel A. (1979): African Historical Studies. London, Totowa: Frank Cass.

Barth, Boris/Osterhammel, Jürgen, eds. (2005): Zivilisierungsmissionen. Imperiale Weltverbesserungen seit dem 18. Jahrhundert. Konstanz: UVK.

Boahen, A. Adu (1987): African Perspectives on Colonialism. Baltimore: The Johns Hopkins University Press.

Brock, W.H. (2004): “Hunt, James (1833-1869)," in: Oxford Dictionary of National Biography, online at: http://www.oxforddnb.com/view/article/ 14194 (accessed on 26.1.2009).

Burton, Sir Richard Francis (1893/1864): A Mission to Gelele, King of Dabome. With Notices of ... the Negro's Place in Nature. (Memorial Edition) Two Volumes. London: Tylston and Edwards. 
Buxton, Thomas Fowell (1839/1838): The African Slave Trade. 2nd ed. London: John Murray.

Cooper, Frederick (2005): Colonialism in Question. Theory, Knowledge, History. Berkeley, Los Angeles, London: University of California Press.

Cooper, Frederick/Stoler, Ann Laura, Eds. (1997): Tensions of Empire. Colonial Cultures in a Bourgeois World. Berkeley, Los Angeles, London: University of California Press.

Curtin, Philip D. (1964): The Image of Africa. British Ideas and Action, 17801850. Madison: The University of Wisconsin Press.

Curtin, Philip D. (1998/1992): The Rise and the Fall of the Plantation Complex. Essays in Atlantic History. 2nd ed. Cambridge, New York, Melbourne: Cambridge University Press.

Darwin, Charles (2007/1871): The Descent of Man, and Selection in Relation to Sex. Online-edition, online at: http://www.forgottenbooks.org (accessed on 10.2.2009).

Davidson, Basil (1994): “Africa and the Invention of Racism," in: Davidson, Basil: The Search for Africa. A History in the Making. London: James Currey, 42-64, 344-345.

Driver, Felix (2001): Geography Militant. Cultures of Exploration and Empire. Oxford, Maldon: Blackwell.

Fyfe, Christopher (1992/1972): Africanus Horton, 1835-1883. West African Scientist and Patriot. Aldershot: Gregg Revivals.

Fyfe, Christopher (1993/1963): A History of Sierra Leone. Aldershot: Gregg Revivals.

Gaillard, Gérald (2004): The Routledge Dictionary of Anthropologists. London, New York: Routledge.

Gould, Stephen Jay (1981): The Mismeasure of Man. New York: W.W. Norton \& Company.

Grau, Ingeborg (2008): “Das Entstehen einer missionarischen 'Weltkirche' und die Verbreitung 'westlicher' Werte in Westafrika im langen 19. Jahrhundert," in: Fischer, Karin/Zimmermann, Susan, eds.: Internationalismus und die Transformation weltweiter Ungleichbeit: Grenzüberschreitende Reformpolitik im 19. und 20. Jahrbundert. Vienna: Promedia, 61-83.

Hallett, Robin (1976): "Changing European Attitudes to Africa," in: Flint, John E., ed.: The Cambridge History of Africa, Volume 5, from c.1790 to c.1870. Cambridge: Cambridge University Press, 458-496, 532-538.

Hirsch, August (1888): "Pruner: Franz B.," in: Allgemeine Deutsche Biographie. Berlin: Duncker \& Humblot, Band 26, 675-676.

Horton, James Africanus B. (1867): Physical and Medical Climate and Meteorology of the West Coast of Africa with V aluable Hints to Europeans for the Preservation of Health in the Tropics. London: John Churchill \& Sons.

Horton, James Africanus B. (1969/1868): West African Countries and Peoples British and Native, with the Requirements necessary for Establishing that Self 
Government Recommended by the Committee of the House of Commons, 1865, and a Vindication of the African Race). Edinburgh: Edinburgh University Press.

Hund, Wulf D. (2006): Negative Vergesellschaftung. Dimensionen der Rassismusforschung. Münster: Westfälisches Dampfboot.

Hund, Wulf D. (2007): Rassismus. Bielefeld: Transcript.

Hunt, James (1863a/1854): Stammering and Stuttering, their Nature and Treatment. $6^{\text {th }}$ ed. London: Longman, Green, Longman, and Roberts.

Hunt, James (1863b): "Introductory Address on the Study of Anthropology, delivered before the Anthropological Society of London, February 24th, 1863," in: The Anthropological Review I (1) May, 1-20.

Hunt, James (1863c) On the Negro's Place in Nature (Read before the Anthropological Society of London, November $\left.17^{\text {th }}\right)$. London: Trübner \& Co.

Hunt, James (1864a): Anniversary Address, delivered before the Anthropological Society of London, January $5^{\text {th }}$, 1864. London: Trübner \& Co.

Hunt, James (1864b) The Negro's Place in Nature: A Paper read before the London Anthropological Society. New York: Van Evrie, Horton \& Co.

Hunt, James (1866) The Negro's Place in Nature: A Paper read before the London Anthropological Society. New York: Van Evrie, Horton \& Company.

Hutchinson, Thomas J. (1861): "On the Social and Domestic Traits of the African Tribes: with a Glance at Their Superstitions. Cannibalism. etc., etc.," in: Transactions of the Ethnological Society of London (1), 327-340.

Huxley, Thomas H. (2001/1863): Man's Place in Nature. New York: The Modern Library.

Kennedy, Dane (2005): The Highly Civilized Man. Richard Burton and the Victorian World. Cambridge, London: Harvard University Press.

Kuper, Adam (1988): The Invention of Primitive Society. Transformations of an Illusion. London, New York: Routledge.

Miers, Suzanne (2003): Slavery in the Twentieth Century. The Evolution of a Global Problem. Walnut Creek, Lanham, Oxford: Altamira Press.

Mudimbe, V.Y. (1988): The Invention of Africa. Gnosis, Philosophy, and the Order of Knowledge. Bloomington: Indiana University Press.

Mudimbe, V.Y. (1994): The Idea of Africa. Bloomington: Indiana University Press.

Pallua, Ulrich (2006): Eurocentrism, Racism, Colonialism in the Victorian and Edwardian Age. Changing Images of Africa(ns) in Scientific and Literary Texts. Heidelberg: Universitätsverlag Winter.

Prichard, James Cowles (1836-47): Researches into the Physical History of Mankind. Five Volumes. $3^{\text {rd }}$ ed. London: Sherwood, Gilbert, and Piper, and J. and A. Arch.

Schön, James Frederick/Crowther, Samuel (1842): Journals of the Rev. James Frederick Schön and Mr. Samuel Crowther, who, with the sanction of Her Majesty's Government, accompanied the Expedition up the Niger, in 1841, in behalf of the Church Missionary Society. London: Hatchard and Son. 
Shepperson, George (1969): "Introduction," in: Horton, James Africanus B.: West African Countries and Peoples. Edinburgh: Edinburgh University Press, vii-xxiv.

Sonderegger, Arno (2002): “J. Africanus B. Horton's The Negro's Place in Nature (1868) - eine frühe Antwort auf den 'wissenschaftlichen Rassismus' des 19. Jahrhunderts," in: Stichproben, Vienna Journal of African Studies (4), 55-80.

Sonderegger, Arno (2008a): Die Dämonisierung Afrikas. Zum Despotiebegriff und zur Geschichte der Afrikanischen Despotie. Saarbrücken: VDM.

Sonderegger, Arno (2008b): "Antisklaverei und Afrika: Zur Geschichte einer Bewegung im langen 19. Jahrhundert," in: Fischer, Karin/Zimmermann, Susan, eds.: Internationalismus und die Transformation weltweiter Ungleichheit: Grenzüberschreitende Reformpolitik im 19. und 20. Jahrbundert. Vienna: Promedia, 85-105.

Sonderegger, Arno (2008c): "Vom Guten, Wahren und Schönen am Ende des 19. Jahrhunderts: Edward Wilmot Blyden, Africanus Horton, Joseph Renner Maxwell," in: Gomes, Bea/Schicho, Walter/Sonderegger, Arno, eds.: Rassismus. Beiträge zu einem vielgesichtigen Phänomen. Vienna: Mandelbaum, 150-175.

Sonderegger, Arno (2009a): "Der Mensch - ein Mängelwesen? Reflexionen zur Geschichte der Kulturanthropologie," in: Schmidinger, Heinrich/Sedmak, Clemens, eds.: Der Mensch - ein Mängelwesen? Endlichkeit, Kompensation, Entwicklung. Darmstadt: WBG, 65-79.

Sonderegger, Arno (2009b/forthcoming): "Abolitionismus in Afrika: Zwischen Zivilisierungsmission und Rassismus," in: Eckert, Andreas/Grau, Ingeborg/Sonderegger, Arno, eds.: Afrika: 1600-1900. Vienna: Promedia.

Stocking, George W. Jr. (1971): "What's in a Name? The Origins of the Royal Anthropological Institute (1837-71)," in: Man, New Series 6 (3), 369-390.

Stocking, George W. Jr. (1991/1987): Victorian Anthropology. New York, Ontario: The Free Press.

Taylor, Mrs. P.A. (1864): "Professor Huxley on the Negro Question," in: Ladies London Emancipation Society, 3-14, online at: http://aleph0. clarku.edu/huxley/comm/Books/Taylor.html (accessed on 22.1. 2009).

Tylor, Edward Burnett (1865): Research into the Early History of Mankind and the Development of Civilisation. London: John Murray.

Waitz, Theodor (1863): Introduction to Anthropology. London: Published for the Anthropological Society, by Longman, Green, Longman, and Roberts.

Wallerstein, Immanuel (2006): European Universalism. The Rhetoric of Power. New York, London: The New Press.

Walvin, James (2006): Atlas of Slavery. Edinburgh: Pearson. 
Wirz, Albert (2000): “Sklavenhandel, Sklaverei und legitimer Handel," in: Grau, Inge/Mährdel, Christian/Schicho, Walter, eds.: Afrika. Geschichte und Gesellschaft im 19. und 20. Jahrbundert. Vienna: Promedia, 75-91.

Wormer, Eberhard J. (2001): "Pruner (auch Prun[n]er-Bey), Franz Ignaz," in: Neue Deutsche Biographie. Berlin: Duncker \& Humblot, Band 20, 747 748. 


\section{A Shared Language: Creative Learning and Slavery}

Marcus Belben

\section{Introduction}

During one of the last workshops of 'A Shared History, A Shared Future', one of the participants asked me, "Can I do it in my own language?" The comment led to a frenetic period of creative work by the group of ten-year-old children I was supporting. The children were imagining themselves to be slaves, recording examples of what slaves might make or do that affects us. Everyone came up with new ideas, not just in their own languages, but the permission to explore for themselves seemed to open up new possibilities for the entire group. The minority in the group who could only speak English fluently experimented with French, or talked to their friends to learn phrases from them. The exercise led to an open debate on what slaves are and where slaves come from. Everyone queued up to record their contribution, illustrating the relevance of the topic to them.

The comment left me reflecting on how we had motivated people to learn about slavery, and provide effective creative learning opportunities on an issue which so many people thought would not interest these school children. For 'A Shared History, A Shared Future' most of the groups started by either visiting the Central Library, or looking through archive material being brought to the groups. We explored relevant archival collections not only relating to the transatlantic slave trade (in which Birmingham played a significant role) but also the various forms of contract labour, bonded labour, indentured labour and other terms that have disguised slavery since before 
the eighteenth century. Initially we intended to invite representatives from community and youth groups across Birmingham to create a script for a performance using archive material that was to be performed in Central Birmingham. To test the feasibility of the project, we put together a collection of images from Birmingham Archives which related to slavery and Birmingham, past and present, and asked participant groups to respond to it. Immediately it became clear that different groups and individuals had a very different understanding of Birmingham's relation to past and present forms of slavery, were interested in looking at different aspects of it, and wanted to explore the issues in very different ways. To ask individuals to work on a single performance with others who were distant from them, to create a performance which could truly be 'owned' by all, would be a logistical nightmare, and not in keeping with our broad aims of giving ownership of the project to participants. We wanted ideas to come from the groups themselves and thus started with an enquiry into who they were, what they thought and how their lives related to slavery. With the support of staff throughout the library service we were able to offer a vast selection of material for participants to find their own material and direct their own smaller projects which covered topics, such as South Africa and Nelson Mandela, black identity through slavery, protest in Birmingham, travel and human trafficking, ships, planes and cargo trucks, guns and handcuff manufacturing, medallions, coins \& jewellery, fashion and football. All enquiries were framed in the historical context of slavery and Birmingham. We worked with groups aged from 2 to 90 and found that slavery can be as relevant and engaging to a group of African Caribbean elders as it was to a Stay and Play group of toddlers and their parents.

The project still included a sharing event, or events, but these would be on the terms of the participants themselves. It took advantage of the community library network across Birmingham to make connections with groups, allowing them to develop their own work, while also giving the opportunity to promote, share, celebrate and commemorate experiences of slavery from the past and present through larger events in their locality and in Birmingham City Centre. The project lasted from February 2007 to February 2008 and included a series of independent smaller projects across the city. The main sharing event in the City Centre was on 1 August 2007 to coincide with the original march of Joseph Sturge in Birmingham. He 
marched to celebrate the end of the apprenticeship system which replaced slavery in all but name, and promoted awareness of the issues of 'modern' slavery of the time in 1838.

Understandably there are practical difficulties for teachers and project workers in adult and youth groups where many languages are spoken. Likewise there are difficulties in communicating with such a broad range of communities with so many different ideas of what slavery is. Our connection with slavery is determined, in large part, by our different cultural beliefs of what slavery is. To complicate our exploration, our abhorrence of slavery leads to natural personal and cultural attempts to distance ourselves from it. Working in your own language' recognises and celebrates the skills and experiences of everyone, rather than imposing a learning experience that will fail many - a principle we followed with all our participants, projects and events. Making our personal and cultural connections with slavery is a first step in a process of empowerment, seeking a clear picture to recognise that we can make a difference. This paper explores how we developed our project to engage people to understand the history of slavery and Birmingham and our place within it.

\section{More Slaves Now Than Ever Before}

On 6 February 2004 the newspaper headlines were dominated by the story of cockle pickers drowned in Morecambe Bay. 23 people had drowned. The identity and status of the people who died was generally not reported as slaves, but as 'illegal immigrants'. Even as recently as 20 June 2007, Jonathan Watts reported for The Guardian that, "the victims were all illegal migrants." Were the victims at Morecambe Bay slaves, and if so, what difference might that make?

In 2007 the Department for International Development (DfID) defined slavery as practices including debt bondage or bonded labour, human trafficking, descent slavery, forced domestic service, and the worst forms of child labour. ${ }^{2}$ Jonathan Watts also reported on the lives of those left behind after the disaster at Morecambe Bay. The families have endured further debt to pay off the debt of those who died, with less means to pay it - "their dependants have re-

1 Watts (2007).

2 Department for International Development (2007), 3. 
ceived no compensation, meagre charity, and endured such appalling harassment from debt collectors that several have been driven from their homes and at least one woman has killed herself."3 Although the victims, and possibly their families, could easily be defined slaves in all the categories listed under the DfID's definition, as 'illegal immigrants', the victims are not entitled to any compensation. The first page of the DfID's brochure on slavery entitled 'Breaking the Chains' quotes Article 4 of the Universal Declaration of Human Rights: "No one shall be held in slavery or servitude; slavery and the slave trade shall be prohibited in all their forms." Justice was served on the gangmasters, but what difference might it have made to the survivors of the Morecambe Bay disaster and the victims' families to be called 'slaves' instead of 'illegal immigrants'? If the press had more widely published a story of slavery in Britain on its front pages instead of the tragic death of illegal immigrants, what difference might that have made to us?

I am using the example of the Morecambe Bay disaster to start to explore how slavery relates to us in our lives. In the project, 'A Shared History, A Shared Future' (ASHASF), we started in the present rather than the past. We wanted to relate to the lives of our participants in the present. Also from our first pilot conducted to gauge the interest of school groups across Birmingham there was a misapprehension that slavery is something that ended two hundred years ago. ${ }^{5}$ Slavery of the past has many similarities with slavery of the present. Likewise our response, mirrored in the press, shares much with attitudes of the past. On the one hand, we abhor its existence, while, on the other hand, we distance ourselves from it, imagining our lives have little to do with it. Comments from teachers working on ASHASF have confirmed this:

I didn't know slavery hadn't ended. [...] It's easy to forget, or pretend to forget, when you are buying things. It's really good to be reminded, [...] Limbo dancing. It's so obvious (about slavery), but I never thought about it. I didn't know how much it still happens. ${ }^{6}$

\footnotetext{
3 Watts (2007).

4 United Nations (1948).

5 See Belben (2008b), 4.

6 Belben (2008b), 11.
} 
Likewise, many teachers and educational professionals could only see the relevance of slavery to black history, and black participants: "I don't think our black children would want to talk about slavery. [...] We'll do slavery in black history month anyway." While many understand slavery in terms of 'The Slave Triangle' of two hundred years ago, contemporary slavery has less to do with race or ethnicity, and far more to do with poverty and the black (illegal) economy. Our understanding of slavery from the way slavery is often taught in UK schools, and the ways it is more widely represented in other media, is that slavery is a Black African American experience. In the UK, the nearness of Eastern Europe and the vastness of the world slave market means that most of 'our slaves' do not come from Africa or America but are representative of every corner of the world. ${ }^{8}$ Contemporary slavery in the UK is in many ways far from the Black African American experience of the past. It has been claimed by many anti-slavery organisations that there are more slaves now than ever before. While few would argue with this statement, to get a clear picture of contemporary slavery is hard. There are as many definitions of slavery as there are countries, law enforcement agencies, academics and persons affected by slavery. Likewise the estimate of slaves in the world today fluctuates from 2.7 million to hundreds of millions. Slavery has been with us since the earliest civilisations. However, the term slavery derives from the Slavs of Eastern and Central Europe, since from the period of the Roman Empire to the Middle Ages many European slaves were of Slavic origin. ${ }^{9}$ In the UK today our experience of slavery is one of a global market. ${ }^{10}$ The experience of contemporary slaves and slavery in the UK is one we can all relate to and one which we must engage with.

\section{Birmingham and Slavery}

Early in 2007 I visited the photographic exhibition 'Slave Britain; The Twenty-First Century Trade in Human Lives' at St Paul's Cathedral in London. I had already researched stories of slavery in the UK and was not expecting to be as moved as I was by the images.

\footnotetext{
7 Belben (2008b), 11.

8 See Robinson \& Rose (2007), 5.

9 See Philologos (2004).

10 See Bales (1999), 232.
} 
There were photographs of streets I recognised in Birmingham, alongside the sordid tales of victims of slavery. ${ }^{11}$ The photographs related my experience, my world, with the experience of slaves in my city. In ASHASF we also wished to foreground this relation to highlight our relation in Birmingham to slavery. Based in the Central Library, we had a wealth of resources to use. We started with a recent story of slavery which many would have heard of, but few seemed to have connected with slavery. In 2005 police raided Cuddles, a Birmingham massage parlour. 19 women were held, pending checks on their immigration status. The women were believed to come from about 10 countries, including Greece, Hong Kong, Italy, Japan, Latvia, Poland and Turkey. A large amount of cash and a shotgun were found on the premises and an electric perimeter fence prevented escape. As the BBC reported, "They had their passports taken. They were locked into the venue during the evening to work and taken away during the day and locked in a house." 12 Although it was reported that the women had been trafficked and were working in the sex industry against their will, once again, there was no mentioning of 'slavery'. The BBC further reported, "Amnesty spokeswoman Sarah Green said there was no protection in law for victims of trafficking, who are usually classed as illegal immigrants and deported. She said: 'Most are deported without any care or support or assessment of the risks they face if sent back."'13 More shocking still, as ASHASF began in January 2007, police raided Cuddles again to arrest two "Hungarians $[. .$.$] for their part in a trafficking operation in$ which women were put to work as prostitutes." 14 How different is this case to the early trials of James Somerset and other slaves represented by Granville Sharpe in the late eighteenth century, who on arrival in the UK fought for their freedom and their right to reside in the UK? Schama summarises Granville Sharpe's argument, "that only a non-person could be deprived of the protection of the King's laws in England (that) was itself rooted in immemorial custom. Repugnance for true slavery in England had swept away the draconian

11 See Robinson \& Rose (2007).

12 BBC News (2005b).

13 BBC News (2007).

14 BBC News (2007). 
law of Edward VI; hence the Elizabethan dictum of the air too pure for slaves (in England) had persisted."15

The different nationalities of slaves has encouraged the British legal system to deport slaves as 'illegal immigrants', but considering the treatment endured by victims of slavery and the likelihood of their having to endure similar treatment if sent back to their country of birth, there is a strong case not to deport former slaves now as much as was the case in the eighteenth century. Similarly, the legal rights and status of slaves and former slaves is dependent on their particular treatment by their 'employers' and their relation to other issues of migration. Sister Margaret Healy, co-founder and trustee of Kalayaan, campaigning for justice for migrant domestic workers, suggests loopholes in recent legislation may actually promote the use of slave labour: "Migrant domestic workers will be given a 'business visitor's' visa, tying them to their employer, with a maximum stay of six months thereby denying them access to redress. This is simply another form of slavery under the guise of Making Migration Work for Britain."16

Birmingham has a rich tradition of resistance against slavery, as well as support of it. Birmingham, the 'city of a thousand trades' has profited from slavery. I was interested in the manufacture of handcuffs, particularly as the Birmingham company, Hiatt, is still in the business of making handcuffs. ${ }^{17}$ Birmingham Archives and Heritage holds a late-nineteenth-century interview with the Birmingham based Hiatt handcuffs firm. Although acting legally, the firm was selling products for use in the slave trade elsewhere in the world. The interviewer's reaction at the end of the discussion confirms that the products made by firms like Hiatt did not go unchallenged then or now. Hiatt's factory in Birmingham has been the focus of protest against Guantanamo Bay over the last six years, as its handcuffs are used on detainees there. The protests contributed to Hiatt's decision to close its Birmingham factory and relocate to the US in June 2008. ${ }^{18}$ Oversized handcuffs, identified by Amnesty International as being used

15 Schama (2005), 46.

16 Robinson/Rose (2007). 'Making Migration Work for Britain' refers to a five year government strategy for asylum and immigration published in 2006. For further information, see Home Office (2006).

17 See Birmingham Archives \& Heritage Newspaper Cuttings Industry 1863-80.

18 See Handcuff Warehouse (2008). 
illegally as leg irons, will thus no longer be stamped 'Made in Birmingham, UK'. ${ }^{19}$

Image 1: Engine drawing illustrating a black slave using a macbine for refining sugar

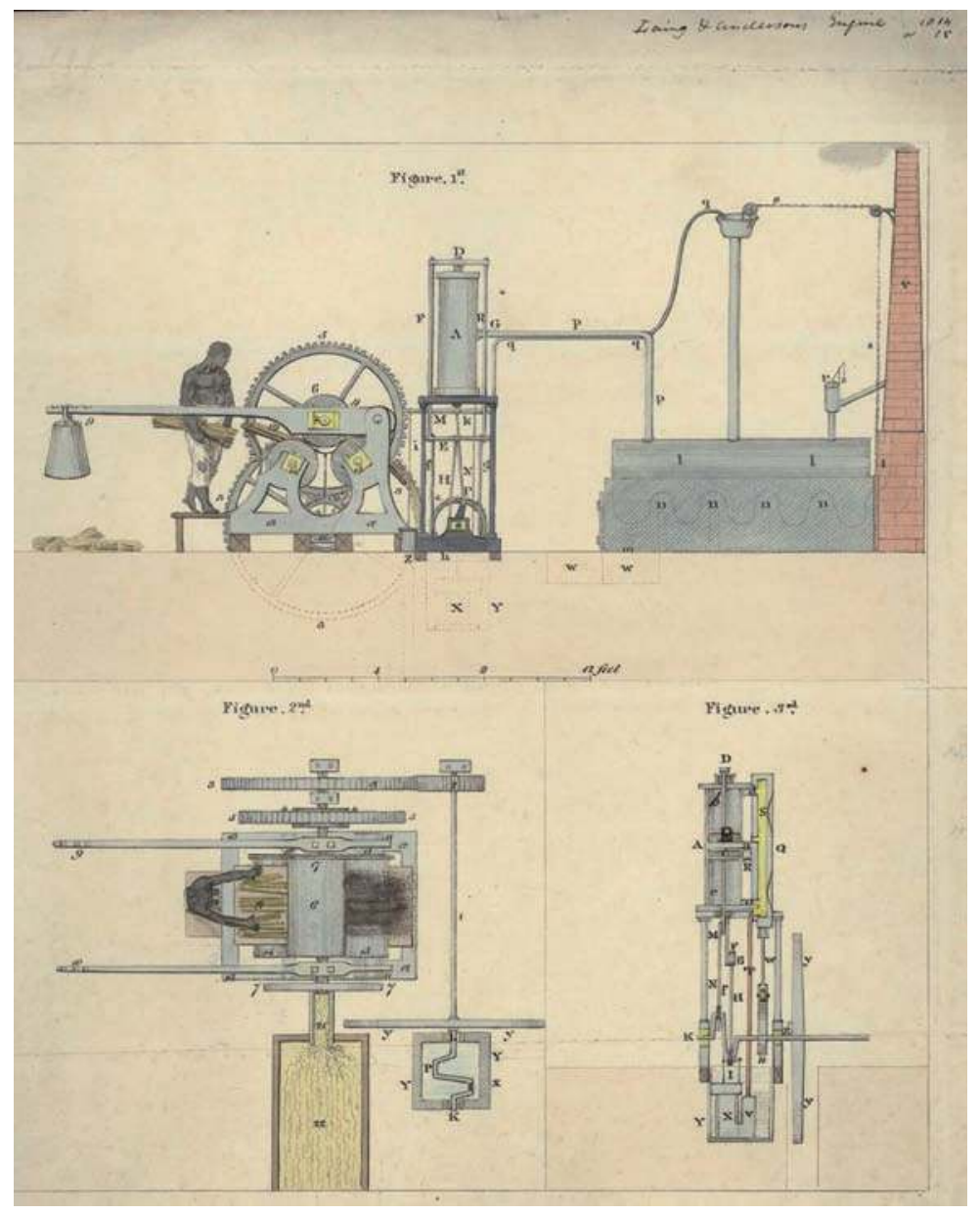

Source: Birmingham Archives and Heritage, MS3147/5/1353b. Courtesy of Birmingham Archives and Heritage

19 See Amnesty International (2004). 
In 2007 Birmingham Archives and Heritage were also running a project called 'Connecting Histories' and, in addition, archivists like Fiona Tait and Amanda Thomas, who were working in Birmingham Archives and Heritage, had already compiled source lists supporting research into slavery and its connection with Birmingham. In the eighteenth and nineteenth centuries Birmingham was responsible for producing manillas (a brass or copper bracelet widely used in Africa as payment for slaves), guns, and steam engines used in sugar plantations (one engine drawing (Image 1) illustrates where the black slave should stand to operate it) and thus profited directly from businesses employing slavery outside England.

While there was support for slavery in Birmingham, there was also well documented protest against slavery, as the Birmingham Female Society for the Relief of British Negroe Slaves and the Birmingham Anti-Slavery Society (Precursor to Anti-Slavery International) as well as figures like Joseph Sturge, Joseph Priestley, Josiah Wedgewood and many others clearly show. There were also figures like Matthew Boulton, who was responsible not only for the production of Watt's steam engines used in sugar plantations, but also for the production of Wedgewood's famous medallion, which was distributed widely to promote the cause of abolishing the slave trade and slavery. ${ }^{20}$

Reference to all the above was made in ASHASF's projects and in ASHASF's first major event on 19 June 2007 - the date the Lifeline Expedition left Birmingham in yoke and chains to complete its epic journey to London. We were fortunate to have the Lifeline Expedition Group, Julie Beckett (a descendant of an African Baptist Missionary and owner of a large manila) and Moazzam Begg (former detainee of Guantanamo Bay) to speak to two invited school groups. ${ }^{21} \mathrm{I}$ had to justify the choice of having Moazzam Begg talk to school groups at an event intended to explore issues of slavery. The choice was based entirely on our relation to slavery in Birmingham today, opening up new possibilities for the groups to explore. As mentioned before, there was the physical and actual link with Birmingham's Hiatt products for restraining slaves. Slaves were stripped of clothes and other cultural references including their religion and 
language. The physical experiences of Moazzam Begg, a Birmingham man, at Guantanamo Bay, although clearly never a slave, bore some similarity to the treatment of slaves in previous centuries, often depicted in yoke and chains as represented on that day by the protest marchers of the Lifeline Expedition.

The term 'enemy combatant' is interesting, particularly its creation, to justify detention and apparently prevent detainees from receiving legal representation. Moazzam Begg denies ever fighting himself, and there is no evidence put forward to suggest he has. ${ }^{22}$ The detainees have, to use Simon Schama's term, become 'nonpersons', deprived of the right to legal protection. ${ }^{23}$ Throughout history new terms have been created or miss-appropriated to disguise slavery and deny slaves their rights and liberties. Ignorance based on racism and religious intolerance has also led to broad acceptance of conditions of slavery. The recent depiction of the Prophet Mohammed as a bomb-wielding, womanizing maniac in Danish cartoons ${ }^{24}$ is comparable to the many English nineteenth-century cartoons of free blacks and abolitionists like Joe 'Gunpowder' Priestley as debauched, crazy and violent. ${ }^{25}$ So by dehumanizing black slaves their callous treatment was justified.

The purpose of ASHASF has been to relate our experiences in Birmingham to the experiences of slaves in the present and the past. Through the Cadburys, Birmingham has a long tradition of chocolate manufacturing. Throughout 1909 the British press reported on the libel trial of the Cadbury Brothers vs. The London Standard News. The Cadburys had a reputation in England and abroad as progressive and highly successful manufacturers of chocolate. The Cadburys were members of the anti-slavery society and William Cadbury himself went on to become one of the first Lord Mayors of Birmingham. Yet the libel trial was William's response to being accused of hypocrisy by the London Standard over the alleged sourcing of cocoa from slave plantations. ${ }^{26}$ This complicated affair constituted the starting point of our investigation into slavery and chocolate, touching on issues of slavery dating from the seventeenth cen-

22 See Begg (2006), and BBC News (2005a).

23 See Begg (2004).

24 See zombietime (2005).

25 See British Library (2006).

26 See Satre (2005), 13. 
tury right up to modern day issues of slavery and fair trade. William Addlington Cadburys collection at Birmingham Archives and Heritage $(\mathrm{BAH})$ gave insight not only into the lives of slaves on plantations in Sao Tome and Principe, but also a personal perspective of the life of William Cadbury and his family. The photographic albums of his travels and his family holidays, his letters to and from his young children, as well as more solid documentation relating to the trial gave a full picture of the period of years in which the trial dominated his life.

We worked with children, some of which had parents or relatives working at the Bournville Factory. Tony Bilsborough from Cadbury Schweppes came to the school to defend their present position and other representatives, such as Dr. Chris Upton, writer for the Birmingham Mail, John Boyle from Midlands Coop, Ruth Thompson from OXFAM and Lorraine Cookson from Fairtrade Association Birmingham, all gave their perspectives and answered the questions of the group. One year group organised raps, a short play, and poetry with storyteller Graham Langley. The project culminated in a balloon debate with characters from the present and the past, including a Fairtrade farmer, a slave from the past, a slave from the present, a chocolate manufacturer and others. The project proved so successful in engaging young people that another group went on to make a film about the Cadbury trial. ${ }^{27}$

Following the story of MV Etireno and its cargo of child slaves in $2001^{28}$ and other stories exposing aspects of slavery in the manufacture of cocoa, leading stakeholders, including cocoa processors and chocolate makers, signed the Harkin-Engel Protocol in 2001 to eradicate slavery and child labour in the chocolate industry by 1 July 2006. The deadline was extended to 1 July 2008, but the International Labour Rights Forum has claimed that the "original intent of the protocol has not been achieved" with industry dragging its feet. "Consumers today have no more assurance than they did eight years ago that trafficked or exploited child labour was not used in the production of their chocolate," states their report. ${ }^{29}$ Our groups were able to follow the present-day story and relate it to the libel case of the Cadburys nearly one hundred years earlier. 
The various groups involved with ASHASF were able to follow the story of slavery in its present as well as past forms. The young people looked at how they could protest, and indeed how people in Birmingham protested in the past. ${ }^{30}$ Every aspect of their project brought them back to Birmingham Archives \& Heritage to research and relate primary sources of people from Birmingham's past with present-day experiences, including research on the internet, meetings with anti-slavery campaigners, a Fairtrade farmer from Nicaragua, a former detainee from Guantanamo, representatives from the press, manufacturers, local councillors, as well as a range of artists supporting their work of finding out for themselves and drawing their own conclusions.

\section{What Has Slavery Got To Do With Me?}

To engage participants we examined how we relate to slavery in Birmingham in the twenty-first century. For 'Chocolate and Slavery' we connected present-day Birmingham with its history of chocolate production and also inquired about the familiarity ten-to-fifteenyear-old children had with chocolate, and how they related to chocolate as consumers. Other groups were inspired to explore other areas of slavery. Lead by textile artist Jane Lutwyche, one school group and an adult community group worked for three weeks examining how we use clothing to express ourselves. We went further, exploring the production of clothing, the growing of cotton, and the cycle of debt and slavery experienced in making our clothes. ${ }^{31}$ We created our own clothes to express what we had found through a fashion show. The group quickly understood the importance of identity through clothing, and also the abuse of people working in the clothing industry. In the first workshop one participant commented, "How is it that slaves make our clothes?" 32 Slavery and child labour is endemic in the production of cotton: from growing, to picking and packaging, all the way to transporting and subsequently processing cotton into cheap, affordable clothing for us. We as consumers also spend a great amount of time and trouble finding and buying clothes that suit us. We looked at archive photos of people from 
Birmingham, ${ }^{33}$ the clothes they wore, and what those clothes might have said about them. The Dunia Yetu drama group also visited the school to show clothes from Togo and Congo and what those clothes mean to them. We then made clothes that said something about us and who we are. We made an item of clothing that said something about what we learned about slavery. A participant commented,

My costume represents slavery. I have been doing this to tell people about slavery. I have enjoyed doing this and also I learned a lot about slavery and the nasty people which buy people and sell. I'm proud to help slavery and free them, therefore I did my best on making the slavery costume. In our School year 6 everyone made a costume like mine, and everyone liked it. Also we had a slavery costume show in our school. We also invited our parents to come and see and learn about slavery and help slaves to be free. We went to Central Library [on the day when the Lifeline expedition visited it in yoke and chains] to learn more about slavery and we did but it was sad to see people wearing chains. ${ }^{34}$

The project involved the children in making their own clothes and their own fashion show. They explored how clothes represent their identity and also how clothes can be used to put across a message:

The clothing I represented was the sad side of slavery, where people have no choice. We had to use designer material which was Fair Trade for the slavery shirt. The back was navy blue and money all around it because slaves can't get money.

My costume represents my thoughts all about slavery. I used the Fair Trade cotton materials. I cut a triangle shape as it was ripped. I drew a chain, wrote slavery in glitter and printed a slavery picture I cut, because slavery clothes get ripped because they only get one pair of clothes. Am I happy with my design? Yes, I am very happy with all the effort I put into it. ${ }^{35}$

The comments of children and the outfits themselves became a major part of the touring exhibition for ASHASF. They were as also reused in subsequent fashion shows. The outfits which were not re- 
claimed by children or the adult community group have become a part of the BAH collections.

Culture is not only expressed through clothing, but also through games. Children use games and play games to learn, and a lot is communicated through them. We took one school group to look at the Parker Archive of Games at the Central Library. Most games, of the past and the present, are of their time and thus say a lot about the children who play them and the adults who buy them. We looked at games like Saucy Sybil and My Lady Betty. Paper dolls have been popular with little girls for a long time and these are particularly fine examples. Their costumes are those of a fashionable young girl in London in the 1890s. We also looked at games like Fancy Bazaar, a trading board game, with hand-coloured cards representing the stall holders and produce cards showing everything from cabbages to fancy goods which were available in shops at the time the game was made. There are also tangrams in the collection. The name is derived from a cross between 'Tan' i.e. from the Tan dynasty, China, and gram, as in 'diagram' meaning pictorial representation. The Game first appeared here in the 1800s, and was more than likely brought to America and Europe by Chinese labourers. When we returned to school, we started to look at other games they might know, and asked them where they might come from. We limbo danced and read poems by John Agard, particularly "Limbo dancer at immigration". The roots of limbo - the loading of slaves onto a slave ship for the limbo journey between the heaven of home and the hell of slavery - were a useful means to start considering slavery, and John Agard's poetry connects the experiences of slaves with more recent experiences of people arriving in England coming from the West Indies. The group then examined their own games and thought about where they had come from and whom they had learned them from. We adapted games and created our own new games that say something about slavery. We used games to examine our identity and explore how slavery works. We adapted 'Snakes and Ladders', where the snakes were the traps to keep people in slavery and the ladders a means of escape from slavery. Most of the games the children created had far more snakes than ladders. In one game we adapted 'Stick in the Mud' to be a slaves and slave catcher game. In this game, when you are touched by the slave catcher, you were 'stuck' until someone else rescued you by touching you. The children 
noticed the only way the 'slaves' could avoid capture and overcome difficulties was when they acted together.

In this group we also worked closely with John Hill-Daniel, a film maker. Throughout the rest of the project we used film and video performance more extensively. One group started with a visit to the Central Library to experiment with video performance and to look at slavery material. We also recorded each participant talking about what they were interested in and whether they thought it had anything to do with slavery. England was still in the European Cup at that stage, and most of the group expressed an interest in football in our early interviews. At the World Cup of 1998 stories circulated that FIFA was using balls produced by children in Pakistan. ${ }^{36}$ In 2008 the same story broke, this time footballs produced by child labourers were given away for free by Switzerland's Credit Suisse Group in the build-up to the Euro 2008.37 As we started to explore this further, it became clear that the production of footballs was often related to child labour. In Sialkot in the Punjab, Pakistan, where many of the world's footballs are manufactured, only one third of children under eleven attended school in 1996. Of those, most were paying for their education by stitching footballs. In 2006 it appears the situation had changed dramatically as a result of international pressure to eradicate child labour in the factories of Sialkot. ${ }^{38}$ However, activists in Pakistan have warned of a resurgence of child labour pushing into ever more remote villages surrounding Sialkot to avoid inspectors. ${ }^{39}$ The group worked with artist Sandra Taylor, VJ Tom Holness and John Hill-Daniel to make their own video performance relating the production of goods like footballs in Pakistan to our being responsible for the working conditions of children making our footballs and asking what we can do about it.

Using sound and video clips, together with drama and other arts media, there is limitless potential for video performance to tell a story. Live performance introduces a potential for interactivity and control in a way a pre-recorded video can never achieve. It is possible for even young participants to control a performance by stopping, starting, altering speed, mixing other images, and interacting 
with other media or live performance elements, allowing changes to be made instantly and easily. It can also remove the pressure of remembering lines, and can provide a visual or audio cue for actors or other performance parts. A parent commented, "The performance brought me to tears. To see the real slaves on the screen, and the children acting out what the slaves were doing was so moving." 40

To make slavery meaningful to participants, it is essential to allow freedom to direct the project. For 'Behind the Game' we started on that premise, and for every workshop we started with a group meeting to plan what we would do that day, and ended with presentations of what we had done, and feedback where two members of the group would take on the role of a teacher. We had a work in progress display wall, added to by the group and the teacher between sessions. The group chose to use other media to contribute to the video performance. The clips included animation, film and artwork. The performance had elements of drama throughout, and the event ended with a song. The group was still making significant changes in the last rehearsal minutes before the performance. ASHASF was based on the principles of creative learning. For the project to have meaning and value, the group needs to relate to the issues, as well as 'own' the project by directing the project and determining its outcome. From football to child soldiers, from fashion shows to games to video performances, each group explored its own experience of slavery in their own way. Using their own 'languages', each group found its own way of connecting with slavery.

\section{What Can I Do About It?}

Each part of our projects had very different outcomes; ${ }^{41}$ early in 2007 Artist Danya Defraytus created an artwork that led to a commission for our project, both intending to promote debate among the general public. She uses national debate and personal interviews to highlight the broad and often controversial range of views relating to an issue that has divided national opinion. Should Britain apologise for slavery? Her artwork invites the audience to add to her work. Other groups were more interested in the process of exploring. One

40 Belben (2008b), 11.

41 For more detailed information, see Belben (2008a). 
group worked with musician Marcella Erskine to create their own stories of slavery with music, developing their own imagined journeys into and out of slavery never to be performed outside the workshop. Most of the projects were interested in making some kind of artwork or performance for a wider audience. Working with John Hill-Daniel, we were able to put together a video record of many of the performances and workshops of ASHASF which are available either on our library web pages or in the Liberty Box.

ASHASF aimed to promote issues of slavery and to encourage people to think and act for themselves. ASHASF worked with over 1000 people in Birmingham in over 150 workshops, reaching many more people through our audiences, examined issues relating to slavery, worked with artists and heritage experts, and was able to use the resources of Birmingham Libraries and Birmingham Archives \& Heritage. Participants created stories, artworks, banners, games, films, dances, drama, video performances and many other art materials to express their emotions, understanding, empathy and disgust of slavery as highlighted in the protest march they took part in.

On 1 August 1838 Joseph Sturge led a march of Sunday Schools from Birmingham Town Hall to mark the end of the apprenticeship system, effectively ending legal slavery in the British colonies. Initially we intended to re-enact the March and to perform a Community Play. We had already decided to work with groups independently. We wanted to bring all participants together for a celebration of their achievements and to promote awareness of slavery in its present and past forms. On 1 August 2007 we marched from St Martin's Church, Bullring, to the Town Hall, carrying banners representing all the groups and projects that had already taken place. We were led by an actor playing Olaudah Equiano and Joseph E. Sturge, great, great nephew of the Joseph Sturge, who had campaigned in Birmingham against slavery 200 years earlier. (Image 2) The march was one of a number of events organised as part of ASHASF in and around Chamberlain Square and the Central Library on 1 August and was attended by over 6,000 people. Throughout the day Sarah Falkland from BBC Midlands Today ran live coverage of the events on the Big Screen, from limbo dancing at St Martin's to a Slavery Fashion Show and Kajan Gospel singing on the Beach at Chamberlain Square. Dunia Yetu created a drama especially for the day, Babmundi drummed, Marcella Erskine sang, Desmond Pusey told sto- 
ries, Tayo Fatunla explored cartoons, and there was also a Fair Trade Market. (Image 3)

Image 2: Commemoration of Joseph Sturge's march in Birmingham on 1 August 2007

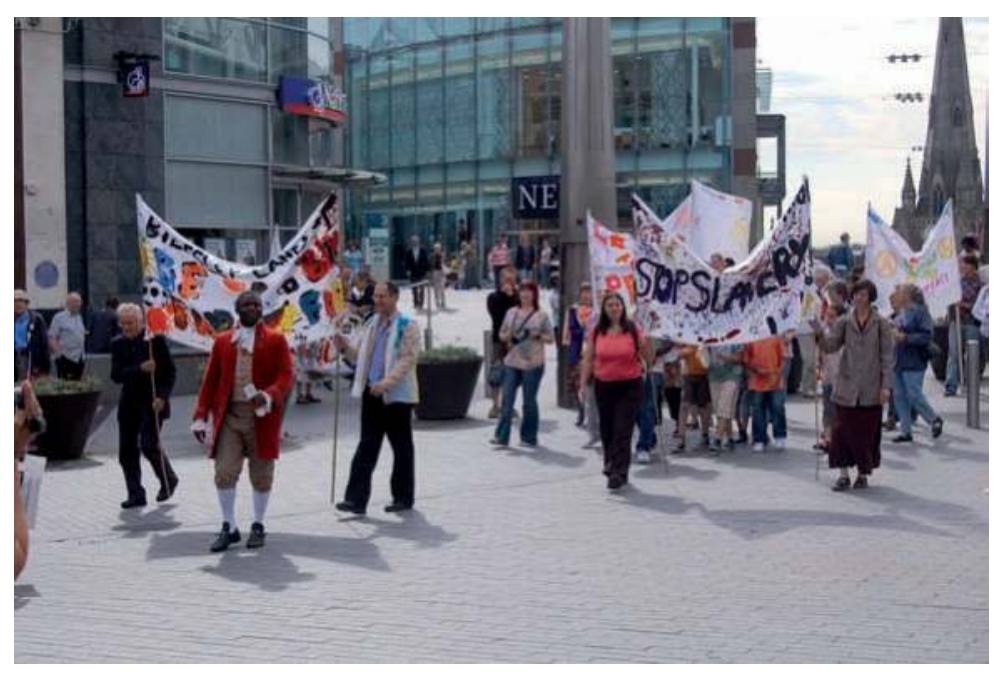

Image 3: Commemoration of Joseph Sturge's march, Chamberlain Square, Birmingham

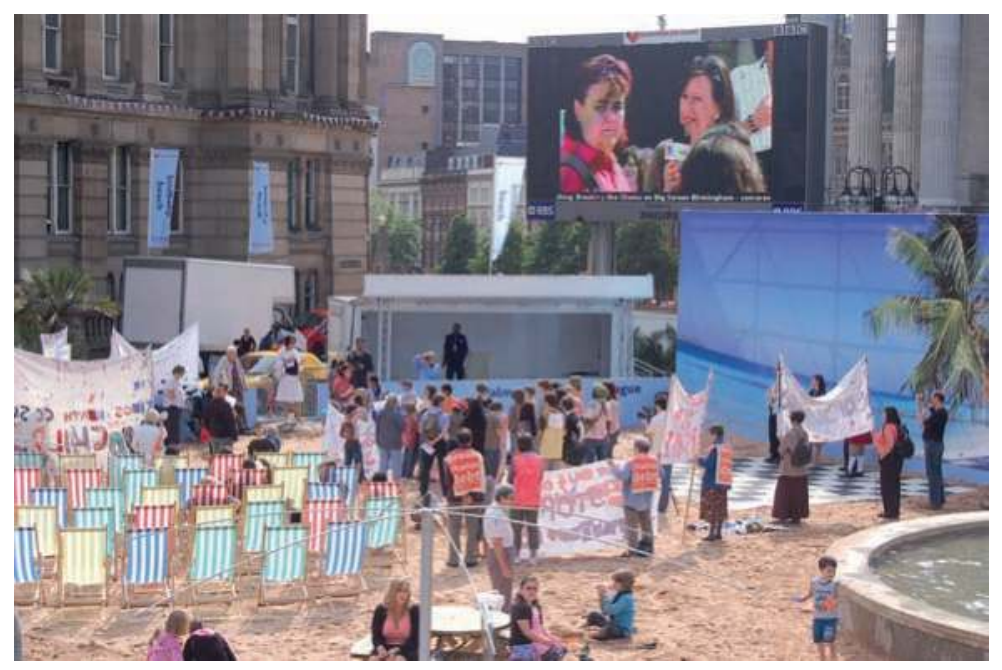


The day ended with a Slavery Question Time special hosted by Olaudah Equiano and inviting discussion of prominent guests like Gemma Wolfes (Anti-Slavery International), Joseph E. Sturge (AntiSlavery campaigner), Bishop Joe Aldred (Breaking the Chains), and Marika Sherwood (author and academic). The sun shone and everything went more smoothly than we could have expected. However, once the day was over we began to reflect on what we had achieved and how best to look forward and support groups and individuals promoting awareness of slavery.

\section{Making Changes, Now and Then}

Slavery is a part of everyone's life. Slavery, and resistance to it, is a part of our present and our past. During 'Fairtrade Fortnight 2008', Tate \& Lyle's announcement to convert all production to Fairtrade sugar was "incredibly well received by customers." 42 Likewise, in the nineteenth century there were also sugar boycotts to promote fair trading. The Female Society for the Relief of British Negro Slaves, which was very active in Birmingham, attempted to persuade the public to boycott sugar from the West Indies, believing that it would contribute to the downfall of the slave trade. ${ }^{43}$ Although our 'March for Justice' took place on the same day and place as Joseph Sturge's march in 1838, it was not a re-enactment of a protest from the past. Joseph Sturge's march was, likewise, not intended only to commemorate the end of colonial slavery. His march ended with the laying of the foundations for Birmingham's 'Negro Emancipation School'. ${ }^{44}$ Our March of 2007 recognised slavery of the past and the present, but also recognised our continuity in the struggle against it, and the need to continue promoting awareness of it.

We invited all Birmingham based projects to discuss what best to do next. We agreed that all groups contribute to our 'Liberty Box' - a catalogued collection of resources presenting a range of campaigns, projects, displays, exhibitions, events and performances in Birmingham in 2007. Throughout ASHASF we reflected the diverse opinions and issues raised in exploring slavery. We wanted to use our resources throughout Birmingham Archives \& Heritage, Bir- 
mingham Library Services and elsewhere to support and promote projects in schools, youth and community groups and elsewhere. In 2007 our project in Birmingham was one of many projects examining slavery, each representing their own understanding of what slavery is and what it means. Throughout the year there was not enough time to support each other, or even to effectively coordinate and promote our events. By acting together we were able to leave a lasting legacy in Birmingham through the Library Service, not just to represent our project, but to record the many projects and resources already available and newly created throughout 2007. Once again, there are historical parallels, since the Anti-Slavery Society was only one of a number of societies and groups acting together to raise awareness of slavery. ${ }^{45}$ The Liberty Box constitutes a snap shot of our attitudes and opinions around issues relating to slavery in 2007 , a record of what we did to raise awareness, change attitudes, and challenge slavery. Due to the constraints of our budget, we had not originally planned an extensive catalogue of resources and projects, so the 'Liberty Box' is a significant achievement. However, our main objective is to promote understanding of how people become slaves, how we are directly or indirectly involved in this process, and what we can do to end slavery. We can learn from our past to see not only how slavery works, but also what we can do to challenge it. For example, Joseph Sturge spent time in Montserrat to ensure the success of his business, The Montserrat Lime Company, which traded up into the 1950s. Joseph Sturge bought the Elberton Sugar Estate in 1857 , wishing to convert it to lime production and to prove that free labour can be made profitable. ${ }^{46}$ By promoting free labour (meaning labourers paid a fair compensation for their work) it can be claimed that Joseph Sturge was one of the pioneers of 'fair trade' one hundred years before the 'Fairtrade' movement gained popular support.

We can engage with slavery in the past and present through Fairtrade, protest, boycotts, leafleting, debate, as well as through media like drama, poetry, music and art - in whatever way is meaningful to us. A creative approach to exploring slavery requires engaging participants, allowing participants the freedom to take direction of a project to find out how they connect with slavery. Unleashing their

45 See Anti-Slavery International (2007), 4.

46 See BAH Montserrat Lime Company Records. 
creativity "generates genuine dialogue and collaboration." ${ }^{47}$ By exploring slavery in this way we are more effectively listening to and more actively involving participants in the project. We are promoting engagement in issues of slavery that are important for present issues of citizenship and social inclusion and for strengthening confidence and resilience in participants to take a more active role in their community. ${ }^{48}$ The statute of Joseph Sturge at Five Ways has seen many changes in Birmingham. Andy Green argues that the restoration of his monument in 2007 could only gain credibility if it is matched by a determination to combat the inequalities confronting our own age. ${ }^{49}$ In exploring our shared history of slavery we must recognise our responsibility for the past, and our shared responsibility to bring slavery to an end.

\section{Works Cited}

Amnesty International (2004): “Quadripartite Select Committee Written Evidence," online at: http://www.parliament.the-stationery-office.co.uk/ $\mathrm{pa} / \mathrm{cm} 200506 / \mathrm{cmselect} / \mathrm{cmquad} / 873 / 873 \mathrm{we} 14 . \mathrm{htm}$ (accessed on 21. 9.2008).

Anti-Slavery International (2007): "The History of Anti-Slavery International," online at: http://www.antislavery.org/homepage/antislavery/ history.pdf (accessed on 11.8.2008).

$\mathrm{BAH}=$ Birmingham Archives and Heritage

"Handsworth Self-Portrait Project," Donor Ref: "Birmingham Museum \& Art Gallery: 1997V184." (1970)

"Memorial of the $1^{\text {st }}$ of August, 1838," Ref. IIR 62/ 158748 (1/2)

"Montserrat Lime Company Records," held in BAH include minutes, papers and photographs. Ref. MS $1436(1 / 5)$.

"Newspaper Cuttings Industry 1863-80," Donor Ref: LSH, LF $64.3(31 / 701)$.

"Papers relating to The Female Society for the Relief of British Negro Slaves," Ref. MS 3338, 361221 IIR62, partly online at: http:// www.birmingham.gov.uk/GenerateContent?CONTENT_ITEM_ID= $2163 \&$ CONTENT_ITEM_TYPE=0\&MENU_ID=11006 (accessed on 11.8.2008).

“The Dyche Photographic Collection," Donor Ref. "Local Studies and History Dyche 0072.” (mostly 1920s to 1960s)

47 Bragg (2007), 5.

48 See Children and Young People's Unit (2001).

49 See Green (2007). 
Bales, Kevin (1999): Disposable People: New Slavery in the Global Economy. Berkeley: University of California Press.

BBC News (1998): "S/W Asia Football Child Labour Lives on," 16 Apr. 1998, online at: http://news.bbc.co.uk/1/hi/world/s/w_asia/78953.stm (accessed on 11.8.2008).

BBC News (2001): “Mystery Surrounds Child 'Slave' Ship,” 17 Apr. 2001, online at: http://news.bbc.co.uk/1/hi/world/africa/1280991.stm (accessed on 11.8.2008).

BBC News (2005a): “A Letter from Guantanamo: In Full," 1 Jan. 2005, online at: http://news.bbc.co.uk/1/hi/uk/3706428.stm (accessed on 11.8.2008).

BBC News (2005b): "19 Women Rescued from 'Brothel'," 30 Sep. 2005, online at: http://news.bbc.co.uk/1/hi/england/west_midlands/4296412.stm (accessed on 11.8.2008).

BBC News (2007) "Pair Jailed for Trafficking Women," 11 Jan. 2007, online at: http://news.bbc.co.uk/1/hi/england/west_midlands/6253697.stm (accessed on 11.8.2008).

Begg, Moazzam (2004): “I, Moazzam Begg, Demand To Be Freed From Guantanamo," Los Angeles Times, 3 Oct. 2004, online at: http://articles. latimes.com/2004/oct/03/opinion/oe-begg3 (accessed on 7.2.2009).

Begg, Moazzam (2006): Enemy Combatant: A British Muslim's Journey to Guantanamo Bay and Back. London: Free Press.

Belben, Marcus/Mohammed, Izzy/Winsor, Brigitte (2008): The Liberty Box. Birmingham: Birmingham Archives \& Heritage.

Belben, Marcus/Birmingham City Council (2008a): "A Shared History, A Shared Future," online at: http://www.birmingham.gov.uk/Generate Content?CONTENT_ITEM_ID=101352\&CONTENT_ITEM_TYPE= 0\&MENU_ID=10596 (accessed on 11.8.2008).

Belben, Marcus (2008b): “A Shared History, A Shared Future," Unpublished Report for Funders, HLF.

Bragg, Sara (2007): “Consulting Young People: A Review of Literature,” A Report for Creative Partnerships. London: Creative Partnerships.

British Library (2006)/Cruishank's Cartoons (1826): online at: http://www. bl.uk/learning/histcitizen/campaignforabolition/sources/antislavery/ johnbullcartoon2/jbullcartoon.html (accessed on 11.8.2008).

Cage, Sam (2008): "Child Labour Fears over Euro 2008 Giveaway Balls," Reuters, 22 Apr. 2008, online at: http://uk.reuters.com/article/oddly EnoughNews/idUKL226524520080423 (accessed on 11.8.2008).

Cahn, Doug (2007): "Child Labour - A Crucial Goal Remains to Be Scored," 1 Feb. 2007, online at: http://www.ethicalcorp.com/content.asp? ContentID=4843 (accessed on 11.8.2008).

Children and Young People's Unit (2001): "Learning to Listen: Core Principles for the Involvement of Children and Young People," online at: 
http://www.thedreammill.com/resources/5\%20DFES\%20Learning\% 20to\%20Listen\%20Core\%20Principles.pdf (accessed on 7.2.2009).

Department for International Development (2007): "Breaking the Chains: Eliminating Slavery, Ending Poverty," online at: http://www2.dfid. gov.uk/ pubs/files/slavery-brochure.pdf (accessed on 21.9.2008).

Green, Andy (2007): "The Joseph Sturge Monument at Five Ways: A Photographic Essay,” online at: http://www.connectinghistories.org.uk/ exhibitions/sturges2.asp (accessed on 11.8.2008).

Handcuff Warehouse (2008), 2 July 2008 online at: http://handcuffware house.blogspot.com/ (accessed on 11.8.2008).

Home Office (2006): “A Points-Based System: Making Migration Work for Britain," online at: http://www.homeoffice.gov.uk/documents/commandpoints-based-migration?view=Binary (accessed on 7.2.2009).

ILO (2006): "From Stitching to Playing: Sialkot Ten Years On," 7 July 2006, online at: http://www.ilo.org/global/About_the_ILO/Media_and_ public_information/Feature_stories/lang--en/WCMS_071247/index.htm (accessed on 11.8.2008).

Partos, Lindsey (10.7.2008): "Best Practice for Chocolate Industry Urgent Voices Child Labour Watchdog," online at: http://www.foodnavigator. com/Financial-Industry/Best-practice-for-chocolate-industry-urgentvoices-child-labour-watchdog (accessed on 11.8.2008).

Philologos (2004): "Slavs, Slovaks, et al. On Language," Forward, 30 Apr. 2004, online at: http://www.forward.com/articles/5583/ (accessed on 7.2.2009).

Robinson, Karen/Rose, David (2007): Slave Britain: The Twenty-First Century Trade in Human Lives. London: Pathos Press, online at: http://www. slavebritain.org.uk (accessed on 16.2.2008).

Satre, Lowell J. (2005): Chocolate on Trial. Slavery, Politics \& the Ethics of Business. Athens: Ohio University Press.

Schama, Simon (2005): Rough Crossings. London: BBC Books.

United Nations (1948): “Universal Declaration of Human Rights," online at: http://un.org/Overview/rights.html\#a4 (accessed on 7.2.2009).

Watts, Jonathan (2007): “Going Under,” The Guardian, 20 June 2007, online at: http://www.guardian.co.uk/uk/2007/jun/20/ukcrime.humanrights (accessed on 11.8.2008).

Wearden, Graeme (2008): “Tate \& Lyle Sweet on Fairtrade Sugar," The Guardian, 22 May 2008, online at: http://www.guardian.co.uk/business/ 2008/may/22/fooddrinks.fairtrade (accessed on 11.8.2008).

zombietime (2005): “The Jyllands-Posten Cartoons", online at: http://www. zombietime.com/mohammed_image_archive/jyllands-posten_cartoons/ (accessed on 11.8.2008). 



\section{List of Contributors}

Marcus BELBEN, B.Eng, M.Sc, M.A., is a freelance community art worker who is also working with Creative Partnerships in Birmingham Schools to develop Creativity in the School Curriculum. He worked on the project "A Shared History, A Shared Future" for Birmingham Library Services in 2007, and is also an editor of the Liberty Box. Before that he was Birmingham City Archives Creative Learning Officer. His publications include, "Birmingham Lives through Children's Eyes," "Rembrandt's Late Self-Portraits: Images of Aging," "A Part of our Lives," "Looking in from the Outside: Community Art and Art Education" and "Home Is Where the Art Is".

Sean CREIGHTON is a freelance community, cultural, heritage and organisational project worker. He works on the histories of the London Boroughs of Lambeth, Merton and Wandsworth, labour and mutual organisations, UK Black \& Asian presence, slavery \& abolition. His published essays include: "Black People in the North East" (North East History, 2008); "Paul Robeson's UK Journey" in Cross the Water Blues: African American Music in Europe (edited by Neil Wynn, University of Mississippi Press, 2007); “Cooperation, Mutuality and Radical Politics" in Co-operatives and Mutuals: The New Challenge (Independent Labour Publications, 2005); "Battersea and the Formation of the Workers' Educational Association" in A Ministry of Enthusiasm. Centenary Essays on the Workers' Education Association (edited by Stephen K Roberts, Pluto Press, 2003); “The Municipal Mecca: The development of the co-operative movement in Battersea" in Towards the Co-operative Commonwealth: Essays in the History of Co-operation (edited by Bill Lancaster and Paddy McGuire, Co-operative College and History Workshop Trust, 1996); “I am a Lancastrian bred and born...': The Life and Times of John Archer, 1863 1932" (North West Labour History Journal 20, 1995/6); “Organised Cycling and Politics: the 1890s and 1900s in Battersea" (The Sports Historian. Journal of the British Society of Sports History 15, May 1995); "The Edwardian RollerSkating Boom" (British Society of Sports History Bulletin 11, 1991). He runs History \& Social Action Publications which has published the following titles: Peter Kuenstler: Learning About Community. Oxford House in Bethnal Green 1940-48; Jason Young: Mother Seacole. Short story; Jonathan Wood: Bill Miller. Plymouth's Black Labour Councillor, Professor Penelope J. Corfield: Vauxhall and the Invention of Urban Pleasure Gardens. A founding member of the Friendly Societies Research Group (1999), and former Secretary of Labour Heritage, he is currently Secretary of Black \& Asian Studies Association. Having been Archival Mapping \& Research Officer for the Tyne \& Wear Remembering Slavery Project in 2007, he now co-ordinates the North East Slavery \& Abolition Group. 
Franca DELLAROSA is Lecturer in English at the University of Bari. Her current research interests include Romantic drama and theatre, theatre and literature in the age of Antislavery, Victorian essay-writing. Her publications include Drama on the Air, a monograph on British radio drama (1997), an edited collection of essays, Poetic and Dramatic Forms in British Romanticism (2006), and Slavery on Stage: Representations of Slavery in British Theatre, 1760s1830 s, a newly completed monograph study, as well as a numerous articles on eighteenth-century and Romantic studies, contemporary literature and cultural mediation. She is presently editing a collection of international essays on Slavery: Histories, Fictions, Memory, 1760-2007 (forthcoming, 2009), and preparing a monograph study on Liverpool abolitionist poet Edward Rushton. She is also working on an edition, with translation, of George Eliot's selected non-fiction prose.

Judith JENNINGS is the Executive Director of the Kentucky Foundation for Women, a private philanthropy supporting feminist art advancing social justice. She earned her Ph.D. in Eighteenth-Century British History at the University of Kentucky in 1975. Her book, The Business of Abolishing the British Slave Trade, 1783-1807 (Frank Cass, 1997), focuses on four Quaker men who helped found the London Abolition Committee and remained active through 1807. "A Trio of Talented Women: Abolition, Gender, and Political Participation, 1780-91," published in Slavery and Abolition 26:1 (April 2005), examines the friendship and abolition activities of Mary Morris Knowles, Anna Seward, and Jane Harry Thresher. Jennings's most recent book, Gender, Religion, and Radicalism in the Long Eighteenth Century: An Ingenious Quaker and her Connections (Ashgate, 2006), focuses on Mary Morris Knowles.

Adrian KNAPP is a Ph.D. candidate in English Literature at the University of Innsbruck. His dissertation focuses on the depiction of revolting African slaves in literary texts of the period of abolition. From 2005 to 2008 he worked on the project "English Literature and Slavery 1772-1834" funded by the Austrian Research Council analysing argumentative patterns of the pro- and anti-slavery debate in The Times. His M.A. thesis, entitled The Past Coming to Roost in the Present: Historicising History in Four Post-Apartheid South African Novels, was published in 2006. His recent and forthcoming publications include "Images of Africa(ns): Racism and Ethnocentricity in the British Abolition Debate: 1787-1834," "The Theatre 'Has Power - The Power to Move': Aspects of Social Change in George Colman's and Paul Leigh's Inkle and Yarico," "Humanitarian Interventionism: Forms of Resistance and Freedom in Thomas Pringle's African Poems" and "The Controversy about the Slave Trade in Britain: Pro- and Anti-Slavery Voices in the The Times, 1789-1833". 
Angela Michele LEONARD, Ph.D. is a tenured Professor of History at Loyola College in Maryland, and currently a Visiting Scholar at Wolfson College (Oxford). Her publications include articles in Cross Currents, Religion and Education, American Society of Environmental History News, American Journal of Semiotics, and Callaloo; entries in the Oxford Companion to Black British History, Encyclopedia of the African Diaspora, and the New Dictionary of National Biography; chapters in Sites of Ethnicity: Europe and the Americas (2004), and World Making (1996); book reviews in Africa Today, Maryland Historical Review, North Carolina History Review, Journal of Southern History, BASA Newsletter, and American Studies International; the following books: Political Poetry as Discourse (Lexington Press, forthcoming), Daniel J. Boorstin: A Comprehensive and Selectively Annotated Bibliography (Greenwood, 2000), and Antislavery Materials at Bowdoin College (Bowdoin, 1991). Her research covers the African-Atlantic Diaspora, memory and monuments, the discourse of jazz and political poetry, critical race theory, and 19th century U.S. and British journalism. Leonard, who completed her academic studies at Harvard/Radcliffe Colleges (A.B., cum laude), George Peabody College of Vanderbilt University (MLS), and the George Washington University (M.A. and Ph.D.), is also a recipient of several prestigious awards, and grants, (including the coveted Hedgebrook Fellowship for Women Writers, the Coolidge Scholarship of the Union Theological Seminary, a Mellon Fellowship from the Virginia Historical Society, and Smithsonian fellowships), and a successful applicant of national seminars, from NEH, Gilder Lehrman, and the Carter G. Woodson Institute of University of Virginia.

Daniel LIVESAY is a Ph.D. candidate in History at the University of Michigan in Ann Arbor. His dissertation examines the migration of mixedrace children from the West Indies to Britain from 1750-1820. Undertaken from extensive research in Jamaican and British archives, this dissertation will explore the complexities and ambiguities of racial ideology in both the Anglo-Caribbean and Georgian Britain. His publications include "Extended Families: Mixed-Race Children and the Scottish Experience, 1770-1820" in International Journal of Scottish Literature 4 (Spring/Summer 2008), as well as book reviews in the Caribbean Quarterly (forthcoming) and European History Quarterly.

Helen MEARS is Keeper of World Art at Royal Pavilion \& Museums, Brighton and Hove. Previously she was African Diaspora Research Fellow at the Victoria and Albert Museum, London.

Ulrich PALLUA is Lecturer in English at Innsbruck University, Austria. He published his Ph.D. thesis Eurocentrism, Racism, Colonialism in the Victorian and Edwardian Age in 2005. He worked on a project entitled "Slavery and 
English Literature: 1772-1834" funded by the Austrian Research Council focussing on the image of African slaves in different literary genres. His recent publications include "Images of Africa(ns): Racism and Ethnocentricity in the British Abolition Debate: 1787-1834," and "The Acceptance of the Evils of Slavery as a Social Phenomenon: an Indicator of a Pro-Slavery Approach." Forthcoming: "Contrasting Group Identities: the Romantic Notion of Africa and Corrupted Europe vs. Britain as the Pioneer of Human Rights in Paul and Virginia," "Images of Africans: Pro- and Anti-Slave Trade/Slavery Voices in The Gentleman's Magazine and The Monthly Review, 1772-1833".

Arno SONDEREGGER is Lecturer in African History at the Department of African Studies, University of Vienna, Austria. His Ph.D. project, financed by the Austrian Academy of Science (DOC), was published as Die Dämonisierung Afrikas: Zum Despotiebegriff und zur Geschichte der Afrikanischen Despotie in 2008. His recent publications include Rassismus: Beiträge zu einem vielgesichtigen Phänomen (co-editor) and "On Writing African History: Schools of Thought and Their (Mis)Representation". Forthcoming: African Studies: Past, Present Future (co-editor). 



\section{Folgende Bände aus der Edition Weltordnung - Religion - Gewalt sind bisher erschienen:}

Wolfgang Palaver, Andreas Exenberger, Kristina Stöckl (Hg.)

Aufgeklärte Apokalyptik: Religion, Gewalt und Frieden im Zeitalter der Globalisierung

Edition Weltordnung - Religion - Gewalt 1

2007, brosch., 448 Seiten, Tabellen und Abb., teilw. in Farbe, ISBN 978-3-902571-41-0, € 27,50

Band 1 versammelt Analysen und Kontroversen zum Thema Religion und Gewalt in Hinblick auf die Herausforderungen, die durch technologische Entwicklungen, wirtschaftliche Globalisierung und zivilisatorischen Wandel entstehen.

Wolfgang Palaver, Roman Siebenrock, Dietmar Regensburger (Hg.)

Westliche Moderne, Christentum und Islam. Gewalt als Anfrage an monotheistische Religionen Edition Weltordnung - Religion - Gewalt 2

2008, brosch., 296 Seiten, Tabellen und Grafiken, ISBN 978-3-902571-59-5, € 21,90

Band 2 untersucht das Verhältnis von Monotheismus und Gewalt im Blick auf die Fragen der Säkularisierung und des multikulturellen Zusammenlebens in Europa. Die einzelnen Beiträge beleuchten dieses Problemfeld unter besonderer Berücksichtung von Christentum und Islam und stellen dabei jeweils historische, systematische oder praktisch-politische Gesichtspunkte und Fragen in den Vordergrund.

Werner W. Ernst (Hg.)

Liebe im Zeichen von Lieblingsliteratur - Einstellungen zur zwischenmenschlichen Liebe an Hand von Lieblingstexten und/oder Lieblingstheorien

Edition Weltordnung - Religion - Gewalt 3

2009, brosch., 182 Seiten, ISBN 978-3-902719-03-4, € 15,90

Band 3 versucht an Hand von Lieblingsliteratur Einstellungen zur zwischenmenschlichen Liebe zu formulieren. So lässt Dostojewski beispielsweise seinen Richter sagen, dass er schuldiger sei als der Verbrecher, da es ihm bislang noch nicht gelungen ist, Verbrechen zu vermeiden. Dieser Gedanke hat für alle Menschen, Generationen, Gesellschaften, Ethnien und Staaten Gültigkeit und könnte die drohende Globalisierung von Vernichtung verhindern.

Wilhelm Guggenberger, Dietmar Regensburger, Kristina Stöckl (Hg.)

Politik, Religion und Markt: Die Rückkehr der Religion als Anfrage an den politisch-philosophischen Diskurs der Moderne

Edition Weltordnung - Religion - Gewalt 4

2009, brosch., 276 Seiten, ISBN 978-3-902719-14-0, € 21,90

Band 4 gibt einen Überblick über zentrale Problemstellungen in der Auseinandersetzung mit dem Verhältnis von Religion und Sozialwissenschaften einerseits, und den spannungsreichen Beziehungen zwischen Religion, Politik, Wirtschaft und struktureller wie offener Gewalt andererseits. Die Aufsatzsammlung empfiehlt sich als Einführung für Studierende in gleichem Maße wie für ein interessiertes Fachpublikum. 